\title{
Humanização Da Assistência Materno-Neonatal: uma Contribuição à sua implantação
}

SANDRA DIRCINHA TEIXEIRA DE ARAÚJO MORAES

Tese apresentada ao Programa de Pós-Graduação em Saúde Pública da Faculdade de Saúde Pública da Universidade de São Paulo para obtenção do título de Doutor em Saúde Pública.

Área de Concentração: Epidemiologia

Orientadora: Prof. Dra.

Cássia Maria Buchalla

São Paulo

2005 
AUTORIZO A REPRODUÇÃO E DIVULGAÇÃO TOTAL OU PARCIAL DESTE TRABALHO, POR QUALQUER MEIO CONVENCIONAL OU ELETRÔNICO. PARA FINS DE ESTUDO E PESQUISA, DESDE QUE CITADA A FONTE.

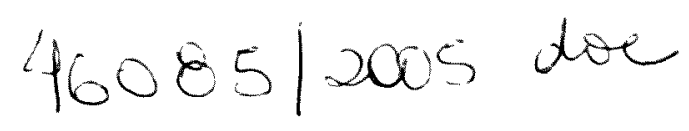

Araújo Moraes. Sandra Dircinha Teixeira

Humanização da assistência materno-neonatal: uma contribuição à sua implantação/ Sandra Dircinha Teixeira de Araújo Moraes; orientadora Cássia Maria Buchalla. São Paulo, 2005.

$\mathrm{XV}, 181 \mathrm{f}$

Tese (Doutorado - Departamento de Epidemiologia da Faculdade de Saúde Pública da Universidade de São Paulo. Área de concentração: Epidemiologia)

Título em inglês: Humanization in the mother-child assistance: a contribuition to implementation.

1. Humanização da assistência em maternidades. 2. Clima organizacional. 3. Violència institucional. 4. A prática dos serviços e do cliente interno. 
Dedico a todos aqueles que sinalizaram com um novo modo de pensar a vida, de estar no mundo, especialmente aqueles que sem saber fazê-lo, o fizeram. 


\section{Agradecimentos}

> A Deus, por senti-lo em todos os momentos da minha vida.

$>$ À direção, funcionárias (os) e usuárias do Hospital Maternidade Interlagos, cuja colaboração foi essencial para a consecução deste trabalho.

$>$ À minha mãe Dirce (in memoriam) que muito precocemente nos deixou órfãos mas um magnífico exemplo a seguir.

Ao meu pai Raul pela sua coragem e ousadia, proporcionando a todos os filhos os estudos que não teve. E a sua esposa Norma pela paciência.

> Aos meus irmãos, Marilza, Raul, Leuces, Leia, Raquel, André, Cristina e Sergio e cunhados/cunhadas, Paulo, José Renato, Agnaldo, Cláudia, Érika, cúmplices e solidários no meu desenvolvimento holístico.

$>$ A todos os meus amigos que sempre confiaram na minha capacidade de chegar até aqui.

> Ao Eli, meu esposo, companheiro da vida, pela fé em meu potencial de pessoa, pela paciência. Vocês são partes integrantes de minha vida e de minha felicidade.

A todos os professores que me ensinaram o que hoje sei.

> À professora Doutora Cássia Maria Buchalla orientadora e amiga, pelo respeito humano e profissional, figura imprescindivel em minha vida acadêmica.

> Aos membros da banca Professores Doutores. Fernado Lefèvre, Ana Cristina d'Andretta Tanaka, Gabriel Alberto Brasil Ventura, Rosalina Carvalho da Silva

> A todos meus colegas de trabalho que sempre possuem um sorriso, uma palavra amiga e que fazem com que eu seja muito feliz por conviver com eles/elas.

> Aos colegas obstetras e demais especialistas do HMI, ao corpo de enfermagem, funcionários da área administrativa, Serviço Social e Serviço de Apoio ao Usuário, psicólogas, nutricionista, voluntárias, enfim todos que de modo direto ou indireto contribuiram com esta pesquisa, dando os seus depoimentos, especialmente os funcionários do Pronto Atendimento, cujas discussões enriqueceram significativamente este trabalho 
$>$ À direção do Hospital Maternidade Interlagos, SES, onde foi desenvolvido esta pesquisa, a Doutora Maria Ângela de Souza ex-diretora da instituição e especialmente ao Doutor Ricardo Wady Gebrim atual Diretor, Doutor Siu Leung, Doutora. Sandra Sestokas, Zuleide Carlos ex-Diretora de Enfermagem, Telma Tizani atual Diretora de Enfermagem, ao Diretor do serviço de obstetrícia Professor Doutor. Mauro Sancovski, a Ester Leal Gerente do Serviço de Apoio ao Usuário, Ângela Aparecida Teixeira de Araújo Diretora do Serviço Social e Solange Aparecida Lemon Diretora do Ambulatório do HMI pela colaboração neste trabalho empenho na Humanização da Assistência.

Às voluntárias do HMI pelo carinho e dedicação e pelo fato de sempre terem acreditado na possibilidade da Humanização da Assistência na instituição.

> Aos Líderes Setoriais de Acolhimento e Humanização da Assistência MaternoNeonatal do HMI pelo empenho e dedicação no processo de Humanização da instituição.

$>$ Em especial aos professores Fernando Lefèvre, Ana Maria Lefèvre, Ana Cristina d'Andretta Tanaka, Vitória Keddy, a pedagoga Jane Penteado, que dedicam carinho e atenção às questões que dizem respeito ao ser humano e por todas suas atenções.

- Às Psicólogas Professora. Doutora. Neusa Guaraciaba dos Santos de Oliveira e Doutora Walkyria Brito Lima, meus agradecimentos pelas discussões e oportunas sugestões que tanto influenciaram de modo construtivo este trabalho.

$>$ À Francisca Evrard, o meu sincero reconhecimento pela acolhida nos momentos dificeis e pela colaboração significativa no levantamento e correção bibliográfica.

$>$ Às bibliotecárias da Faculdade de Saúde Pública, pela colaboração na correção bibliográfica.

> A todas as funcionárias da Pós-Graduação e do Departamento de Epidemiologia da Faculdade de Saúde Pública pelo apoio e amizade, em especial a Renilda e a Miriam.

> A Simone Lopes pela transcrição das fitas, digitação, confecção de tabelas e paciência que me dispensou, no decorrer deste trabalho. 
"Mais poderosa do que o avanço dos exércitos é uma idéia cujo tempo chegou".

(Vitor Hugo) 


\section{RESUMO}

Araújo Moraes SDT. Humanização da Assistência Materno-Neonatal: Uma contribuição à sua implantação. São Paulo; 2005. [Tese de Doutorado - FSP/USP].

Introdução: $O$ presente trabalho analisou as condições estruturais de trabalho do Hospital Maternidade Interlagos e seu Ambulatório sob a ótica do profissional, as concepções dos sujeitos sobre a humanização da assistência e o caráter coletivo deste trabalho visando propor mudanças no modo de atendimento.

Metodologia: A técnica de MARIOTTI (2000) foi utilizada para a avaliação do clima organizacional, observação direta do cotidiano de trabalho em setores distintos da instituição,28grupos focais e 67 entrevistas em profundidade com profissionais de todas as categorias e analisadas segundo LEFĖVRE e LEFÈVRE (2000).

Resultados e Discussão: a Pesquisa do Clima Organizacional evidenciou: conformismo: alto $(71 \%)$, mediano $(16 \%)$ e baixo (13\%); responsabilidade: pouca ou nenhuma $(72 \%)$, mediana $(21 \%)$ e alta $(7 \%)$; motivação: pequeno $(66 \%)$, mediano $(20 \%)$ e grande (14\%); recompensas: pequeno $(74 \%)$, mediano $(19 \%)$ e alto $(7 \%)$; verticalidade: alto (58\%), mediano (35\%) e baixo (7\%); horizontalidade: excessivo (35\%), satisfatório $(58 \%)$ e baixo $(7 \%)$. Os médicos foram os profissionais que ofereceram maior resistência e os auxiliares de enfermagem os que mais colaboraram no processo de humanização da assistência. Quanto a violência institucional, a comunicação insatisfatória entre as lideranças, entre estas e os demais profissionais, estrutura fisica e equipamentos de trabalho inadequados foram fatores relevantes. $O$ alto nível de conformismo sinalizou a intensidade da resignação do cliente interno, uma postura pessimista e negativa.Como conseqüência da deficiência de delegação de responsabilidades por parte da instituição observou-se: falta de dedicação, por insatisfação pessoal; os problemas não resolvidos eram com frequeência ignorados mas sempre voltando agravados e, significativo absenteismo setorial, sobretudo nas áreas de maiores demandas. As deficiências de motivação e comprometimento compartilhado sinalizou o baixo nível de comprometimento com conseqüentes surgimentos de compartimentos estanques ("ilhas" organizacionais); aumento da resistência a ações e práticas novas, no caso implantação/implementação da Humanização da Assistência Materno-Neonatal e a incorporação de novos membros; As chefias se desinteressavam muito pela vida pessoal dos funcionários e observou-se incremento dos boatos e intrigas de corredor. Provavelmente devido o pequeno nível de recompensas observou-se na 
instituição uma atmosfera de impessoalidade e queda da doação espontânea de feedback entre equipes e profissionais. Foi ainda, observado incerteza sobre o que representa 0 trabalho; aumento da rotatividade dos membros em áreas críticas; aumento de horas extras e de trabalho; conflitos sobre autoridade e responsabilidade; falta de base para tomadas de decisão. O mediano nível de comunicação e clareza referido por $83 \%$ dos funcionários significa que o grau de ordem, bom funcionamento, transparência de atitudes e clareza de definição de objetivos da instituição não era satisfatória. O nível de calor humano e apoio referido como baixo por quase metade do cliente interno refletia a carência de amizade e entendimento que existia na instituição. $O$ alto nível de verticalidade sinalizava o excesso de hierarquia e pouca flexibilidade em determinados setores e esta variável contribuía para a resistência institucional à mudança e o comprometimento da qualidade assistencial. O nível de horizontalidade considerado excessivo por $35 \%$ representava o grau de informalidade da organização e conseqüentemente freqüentes boatos, intrigas de corredor e ressentimentos.

Conclusão: $O$ estudo demonstrou a importância da prévia utilização da pesquisa do Clima Organizacional, conhecendo o nível de satisfação ou insatisfação do cliente interno com o trabalho quando se pretender implantar a humanização da assistência nas instituições de saúde. Isto facilitou os processos e fatores críticos presentes na relação entre as gerencias e demais funcionários viabilizando o prévio acolhimento do cliente interno colaborando assim na implantação da assistência humanizada ao parto e nascimento.

Palavras-Chave: Humanização da assistência em maternidades, clima organizacional, violência institucional, a prática dos serviços e do cliente interno. 


\section{SUMMARY}

Araújo Moraes SDT.Humanization of neonatal-maternal assistance: $\mathbf{A}$ contribution to implementation (Ph.D. thesis-FSP-SP)

The present work analyzed the working structural conditions of the HMI and its Outpatient Clinic from the perspective of the internal client, the conceptions of the subjects on the humanizing of assistance and the collective nature of such work, aiming at changes in the attending mode.

Methodology: The MARIOTTI technique (2000) was used for the evaluation of the organizational atmosphere, direct observation of the work quotidian in different sectors of the institution, focal groups and 67 in-depth interviews with all categories that were analyzed according to LEFÈVRE e LEFÈVRE (2000).

Results and Discussion: The Organizational Atmosphere Survey showed levels of Conformism - high (7.1\%) average (16\%), low (13\%); Responsibility - little or none (72\%), average (21\%), high (7\%); Motivation - low (66\%), average (20\%), high (14\%); Reward - low (74\%), average (19\%), high (7\%); Verticality - high (58\%), average $(35 \%)$ low (7\%); Horizontality - excessive (35\%), satisfactory $(58 \%)$, low (7\%). The doctors were the professionals that presented the most resistance and the nursing assistants were those that collaborated the most in the assistance humanization process. Concerning institutional violence the relevant factors were the unsatisfactory communication between the leaderships and between these and the other professionals, the inadequate physical structure and work equipment. The high level of conformism pointed to the intensity of resignation and a negative and pessimistic attitude on the part of the internal client. The following facts were seen as consequence of the deficient delegation of responsibilities by the institution: lack of dedication due to personal dissatisfaction, unsolved problems frequently ignored and frequently recurring in aggravated forms, significant sectorial absenteeism mainly in the most needed areas. The motivation deficiencies and shared commitment signaled the low level of commitment and consequent occurrences of isolated compartments (organizational 'isles'); increase of resistance to new actions and practices concerning the implementation of the Neonatal-maternal Humanization Assistance along with the incorporation of new members. Also noted was the lack of managerial interest on the personal life of employees and an increase of gossip and corridor intrigue. The presence of impersonal atmosphere and a decrease in the spontaneous feedback contribution between teams and professionals probably due to the low level of reward was also 
observed. Other aspect found the uncertainty of what the work represents, increase of rotation of members in critical areas, increase of extra work hours, conflicts over authority and responsibility and lack of basis for decision making. The median level of communication and clarity referred by the $83 \%$ of the workers means that the level of order, efficiency and attitude transparency along with clarity in the definition of objectives of the institution was dissatisfactory. The level of human warmth seen as low by almost half of the internal clients reflected the lack of friendship and understanding in the institution. The high level of verticality signaled the excessive hierarchy and low flexibility in certain sectors, which contributed to the institutional resistance to change and the impairment of assistential quality. The level of horizontality considered by $35 \%$ as excessive represented the level of informality of the organization the consequent frequent hearsay, corridor intrigue and resentment.

Conclusion: The study showed the importance of the use of the Organizational Atmosphere Survey for the study of the level of satisfaction or dissatisfaction of the internal client concerning work prior to the implementation of assistance humanizing programs in health intimations. Such procedure proved positive in the processes and critical factors present in the relations between the management and the workers which made the responsiveness to the internal client thus contributing to the implementation of humanized labor and birth assistance.

Descriptors: maternity ward assistance humanization, organizational ambience Podemos discutir, se quizer !), institutional violence, the practice of services and the internal client. 


\section{LISTA DE SIGLAS E ABREVIATURAS}

Siglas / Abreviaturas

$\mathrm{ABQV}$

$\mathrm{A}$

$\mathrm{AC}$

$\mathrm{AE}$

$\mathrm{AL}$

Aloj. Conjunto

CEVMM

CIP

CLAP

$\mathrm{CO}$

CPN

DA

DC

$\mathrm{DE}$

DG

DP

DRH

DSC

DU

E

$\mathrm{ECH}$

Func.

GO

I

IC

$\mathrm{L}$

$\mathrm{N}$

NUT

$\mathrm{O}$

$\mathrm{OA}$
Nome

Associação Brasileira de Qualidade de Vida

Anestesiologista

Ancoragem

Auxiliar de Enfermagem

Auxiliar de Limpeza

Alojamento Conjunto

Comitê Estadual de Vigilância a Morte Materna Secretaria de Estado da Saúde - São Paulo

Coordenação dos Institutos de Pesquisa

Centro Latino Americano de Perinatologia

Centro Obstétrico

Centro de Parto Normal

Diretor de Ambulatório

Diretor Clínico

Diretor de Enfermagem

Diretor Geral

Departamento Pessoal

Diretor de Recursos Humanos

Discurso do Sujeito Coletivo

Diretor de Serviço de Apoio ao Usuário

Enfermeira

Expressão Chave

Funcionário

Ginecologista Obstetra

Intensivista

Idéia Central

Lideres Setoriais de Acolhimento

Neonatologista

Nutricionista

Obstetra

Oficial Administrativo 
OMS

OPAS

$P$

PCO

PNHAH

PNL

OS

$\mathrm{R}$

$\mathrm{RH}$

$\mathrm{RN}$

REHUNA

$\mathrm{S}$

SAME

SES

SUS

TL

UTI
Organização Mundial da saúde

Organização Pan-Americana da Saúde

Psicólogo

Pesquisa de Clima Organizacional

Programa Nacional de Humanização da Assistência Hospitalar

Programação Neurolinguística

Pronto Socorro

Residente de Obstetrícia

Recursos Humanos

Recém-Nascido

Rede de Humanização do Parto e Nascimento

Segurança

Serviço de Arquivo Médico Estatístico (Atualmente Núcleo de Internação e Informação em Saúde)

Secretaria de Estado da Saúde

Sistema Único de Saúde

Técnico de Laboratório

Unidade de Terapia Intensiva 


\section{INDICE}

RESUMO

SUMMARY

LISTA DE SIGLAS E ABREVIATURAS

I. INTRODUÇÃO.. 1

1.1 A humanização da assistência como norteador no cuidado à saúde........1

1.2 Desafios na implantação de uma politica estratégica de humanização

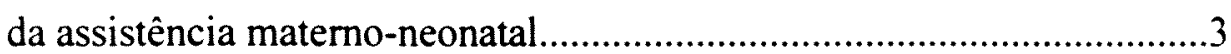

2. ANÁLISE CRÍTICA DA LITERATURA .........................................

2.1 Apropriação do parto pelos médicos........................................................

2.2 Consequiências do excesso de tecnologia do parto e nascimento .............7

2.3 “Amigas da parturiente" (Doulas): parceiras na humanização da assistência materno-neonatal...............................................................9

2.4 Centro de Parto Normal e Nascimento: onde os partos e nascimentos humanizados acontecem...................................................10

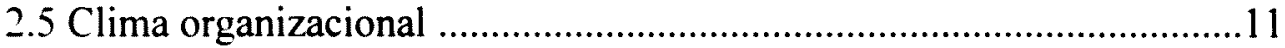

2.6 Preparando o cliente interno para as mudanças......................................14

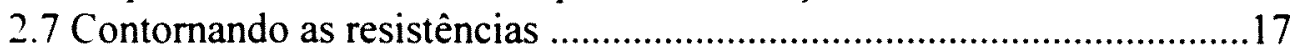

2.7.1 Benefícios da mudança..................................................................20

2.7.2 Resgatando a humanidade do atendimento......................................21

3. OBJETIVOS

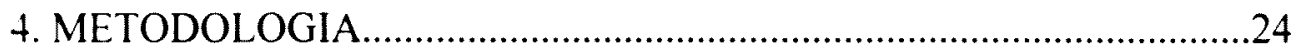

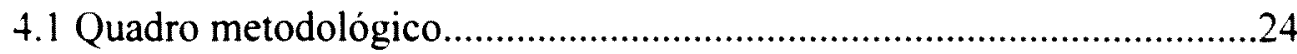

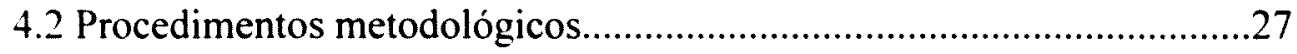

4.2.1 Desenho do estudo...........................................................................27

4.2.2 Local do estudo - Hospital Maternidade Interlagos e seu

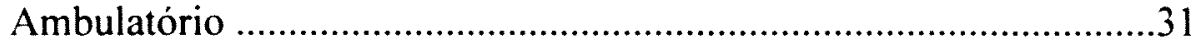

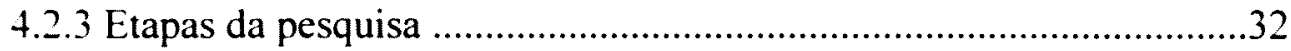

4.2.4 Observação dos diversos setores do Hospital Maternidade

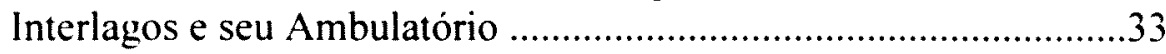

4.3 Descrição dos ambientes onde foram realizados os grupos focais e

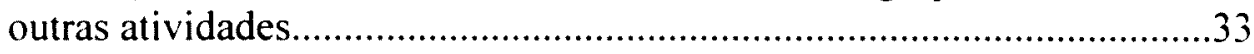

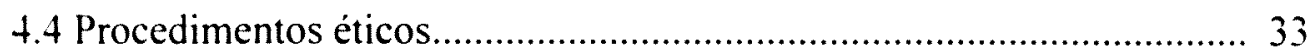

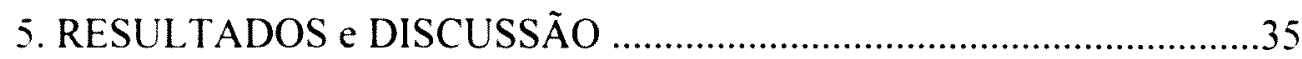

5.1 Clima Organizacional do Hospital Maternidade Interlagos e do seu

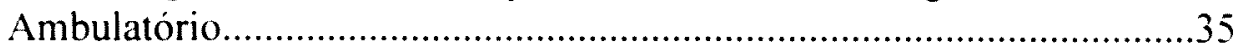

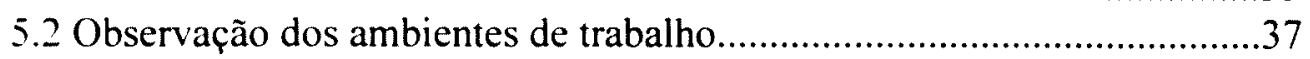

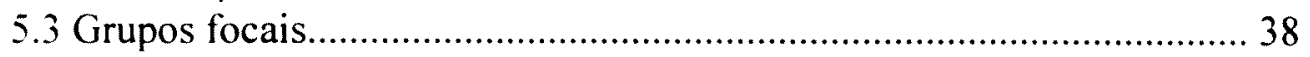

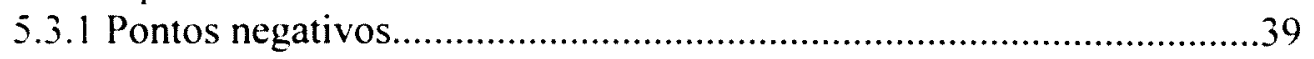


5.3.1.1 Em relação à interação profissional................................................39

5.3.1.2 Em relação à infra-estrutura..........................................................40

5.3.1.3 Em relação à comunicação e integração entre os funcionários.........43

5.3.1.4 Em relação ao quadro pessoal........................................................44

5.3.1.5 Em relação ao treinamento e organização do trabalho......................45

5.3.1.6 Em relação aos direitos dos usuários..............................................46

5.3.2 Pontos positivos da instituição......................................................46

5.3.2.1 Em relação à interação profissional...............................................46

5.3.2.2 Em relação à infra-estrutura.........................................................47

5.3.2.3 Em relação à comunicação e Integração entre os funcionários.........47

5.3.2.4 Em relação ao quadro pessoal..........................................................48

5.3.2.5 Em relação ao treinamento e organização do trabalho......................49

5.3.2.6 Em relação aos direitos dos usuários...............................................49

5.3.3 Sugestões de melhoria institucional por parte do cliente interno.........50

5.3.3.1 Quanto à interação profissional...................................................50

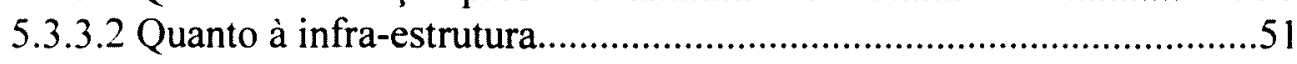

5.3.3.3 Quanto à comunicação e integração dos serviços.............................52

5.3.3.4 Quanto ao quadro pessoal.........................................................52

5.3.3.5 Quanto ao treinamento e organização institucional..........................53

5.3.3.6 Quanto ao direitos dos usuários.....................................................53

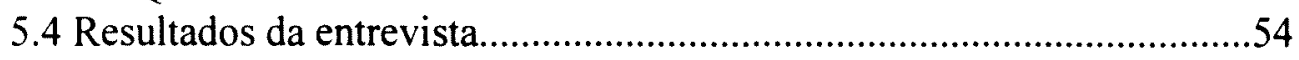

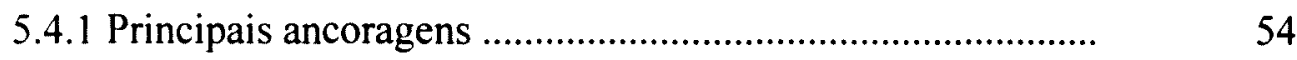

5.4.2 Discurso do sujeito coletivo.......................................................60

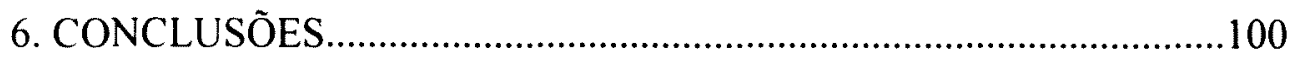

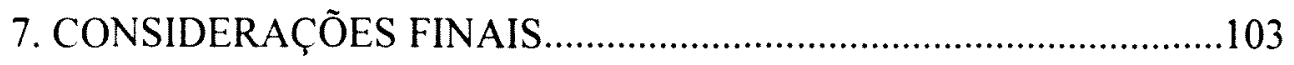

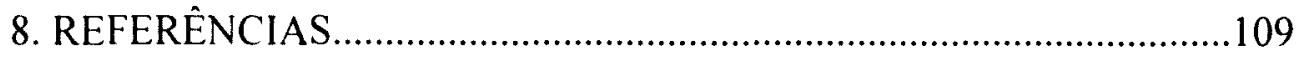

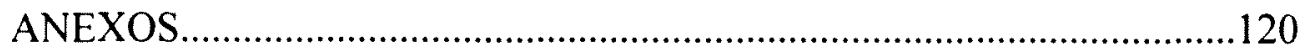

Anexo 1. Questionário - Avaliação de clima organizacional....................120

Anexo 2. Formulário de consentimento informado...................................123

Anexo 3. Roteiro para os grupos focais...................................................125

Anexo 4. Roteiro das entrevistas em profundidade..................................126

Anexo 5. Parte dos resultados das entrevistas em profundidade.................127 


\section{INTRODUÇĀO}

\subsection{A humanização da assistência como norteador no cuidado a saúde}

Os termos "humanização" e "acolhimento" vêem sendo utilizados com muita freqüência no âmbito da saúde. Entendemos humanização como o processo de transformação da cultura institucional que reconhece e valoriza os aspectos subjetivos, históricos e socioculturais dos atores sociais - usuários e profissionais - envolvidos nas práticas de saúde. melhorando as condições de trabalho e a qualidade do atendimento (SES 2003).

Humanização é a base de um amplo conjunto de iniciativas, mas não possui uma definição mais clara, geralmente designando a forma de assistência que valoriza a qualidade do cuidado do ponto de vista técnico, associado ao conhecimento dos direitos do paciente. de sua subjetividade e cultura, além do reconhecimento do profissional (ROBERTSON 1994: DESLANDES 2004).

O termo "humanizar" e seus derivados têm adquirido sentidos diversos (DINIZ 2001). Um dos conceitos de humanização adotado pelo Hospital Maternidade Interlagos é o de JONES (2001). ou seja, uma atenção que reconhece os direitos fundamentais de mães e crianças. além do direito à tecnologia apropriada. baseada na evidência cientifica. Isso inclui: o direito à escolha das pessoas envolvidas e das formas de assistência no parto: a preservação da integridade corporal da parturiente; o respeito ao parto como experiência altamente pessoal, sexual e familiar: e o apoio emocional, social e material no ciclo gravídico-puerperal; assim como a proteção contra abuso e negligència.

Os conceitos de acolhimento e humanização da assistência pretendem-se norteadores de uma nova práxis na produção do cuidado em saúde. $\mathrm{O}$ acolhimento ao ser adotado como estratégia para reconfigurar o processo de trabalho nos equipamentos de saúde. pretende otimizar o acesso dos usuários aos serviços de saúde, humanizando as relaçōes entre os clientes interno (funcionários) e externo (pacientes), em especial no que tange a forma de recepcionar estes usuários e de escutar seus problemas e/ou demandas. numa abordagem que contemple não apenas a dimensão biológica mas também a psicológica. a social e a cultural; aperfeiçoando o trabalho em equipe com a integraçào e a complementaridade das atividades exercidas por cada categoria. buscando $o$ atendimento segundo os riscos apresentados. complexidade do problema. além do grau do saber e tecnologias exigidas para a solução. critérios esses que também 
são a base para a definição dos papeis, das competências e responsabilidades de cada categoria profissional, no trabalho em equipe.

$\mathrm{O}$ acolhimento constitui-se em um potente disparador de mudanças, permitindo uma profunda reflexão dos problemas existentes na instituição, os quais com a mudança do processo de trabalho vem a tona com toda a força: área física inadequada, insuficiência quantitativa e capacitação de Recursos Humanos, ausência e/ou protocolos inadequados. sucateamento dos equipamentos e ambulâncias, carência de leitos, falhas dos processos gerenciais, afloraram como problemas emergentes.

As diretrizes tomadas pelo Ministério da Saúde no sentido de mudar e de humanizar os serviços de saúde esbarram quase sempre com grande inabilidade do campo de fazer o acolhimento acontecer através dos próprios funcionários.

Evoca ROBERTSON (1994) que durante o século 20, avanços científicos e tecnológicos afetaram todos os aspectos da nossa vida, e a maneira como nascemos é ainda mais significativo, uma vez que, diferentemente das outras especialidades. estas práticas irão intervir sobre mulheres e crianças supostamente saudáveis, e num processo supostamente normal, o parto.

O desenvolvimento de tecnologias médicas capazes de reduzir danos à saúde da mulher e do recém-nascido têm dirigido a assistência ao parto e nascimento para a dimensão do intervencionismo, traduzida no aumento da prevalência de partos cirúrgicos (DAVIS-FLOYD 1997). E, também no Brasil grande parte dos profissionais de saúde que atuam nesta área têm absorvido esta cultura (LIPPI et al. 1998). O preocupante é que em paises desenvolvidos essa realidade não se apresenta de forma tão significativa quanto na nossa região. Em alguns países, principalmente europeus como a Inglaterra. Holanda e França se compreende o processo de parir de forma mais natural e os processos de intervenção médica são reservados para as situações em que são esperadas complicações. Perguntamos, que outros fatores estariam interagindo com o avanço tecnológico propiciando o incremento dos partos cirúrgicos?

Frente a necessidade de humanizar o atendimento dos pacientes nas unidades públicas de saúde. considerando que a humanização implica na adoção de práticas em que profissionais e usuários considerem o conjunto dos aspectos fisicos. subjetivos e sociais. assumindo postura ética de respeito ao outro. de acolhimento do desconhecido e reconhecimento de limites o Ministério da Saúde em junho de 2000, institui o Programa de Humanização no Pré Natal e Nascimento (MINISTÉRIO DA SAÚDE 2000). Diante deste fato os hospitais da rede SUS sentiram-se na obrigação de reverem suas praticas. 
As evidências apontam que os beneficios da humanização resultam na qualificação da relação recepção/usuário com parâmetros de solidariedade e cidadania e que o relacionamento entre os pacientes e os profissionais de saúde são a base de uma assistência de qualidade (WAGNER 1994; BALLINT 1997).

Então questionamos aonde começar com o processo de humanização? Aonde a instituição em estudo (HMI e o seu Ambulatório - SES) pretende chegar com a mudança e qual o papel que os clientes internos terão de desempenhar para a real implantação do acolhimento e humanização da assistência materno-neonatal?

\subsection{Desafios da implantação de uma política estratégica de humanização da assistência materno-neonatal}

$\mathrm{A}$ insuficiência de politicas públicas que respondam às reais necessidades dos funcionários. inexistência de programas de educação em saúde dirigidos especialmente para esta demanda. sobretudo para aqueles profissionais que tem contato constante e direto com o usuário de baixo nível sócio-econômico-cultural são igualmente responsáveis pelo incremento das taxas de morbidade e mortalidade materno-infantil ao lado da falta de humanização na assistência ao parto e nascimento, seja pela medicalização e tecnologização excessiva. seja pela desrespeitosa existência de relações entre instituição, profissionais de saúde e a clientela (CFM 1997).

Apesar do Estado de São Paulo concentrar a maior população e riquezas do país. é. ao mesmo tempo, um dos estados que exibem maiores desniveis sociais. Como reflexo verificamos uma superposição de perfis da morbidade-mortalidade característicos de paises desenvolvidos e em desenvolvimento (MINISTÉRIO DA SAÚDE 2002).

No Brasil. as mulheres em idade reprodutiva representam $25 \%$ da população geral (BERQUÓ 1993). A taxa de mortalidade materna no Brasil corresponde a 73.8 mortes para cada 100 mil nascidos vivos (SES 2004), sendo que segundo estudos de aproximadamente $90 \%$ destas mortes poderiam ser evitadas. Vale lembrar que a morte materna e um dos mais sensiveis indicadores de iniqüidade. desarticulação e desorganização da assistência à saúde. da falta de uma política pública que responda as necessidades das mulheres (TANAKA e MTSUIKI 1999). 
Por outro lado, a mortalidade perinatal, isto é, aquela ocorrida nos primeiros dias de vida, representa $50 \%$ das mortes de crianças menores de um ano (MINISTÉRIO DA SAÚDE 2002). Como principais fatores responsáveis por este quadro podemos apontar:

- A abrangência inadequada e a baixa qualidade da assistência obstétrica oferecida à população materna e de cuidados neonatais aos recém-nascidos

- O sistema inadequado de informação sobre mortalidade e prestação de serviços de saúde, que dificultam o gerenciamento das ações nos níveis municipal. estadual e federal;

- Desarticulação e desorganização da assistência à saúde materno-neonatal, falta de acesso à serviços de qualidade e desintegração dos serviços de saúde:

- Insuficiência de políticas públicas que respondam às reais necessidades das mulheres. inexistência de programas de educação em saúde dirigidos especialmente para gestantes e famílias, sobretudo aquelas de baixo nivel sócio-econômico e cultural;

- A falta de humanização no atendimento na assistência ao parto e nascimento, seja pela medicalização e tecnologização excessiva, seja pela existência desrespeitosa de relações entre instituição, profissionais de saúde e a clientela.

É consenso que não adianta pretender fazer mudanças organizacionais ou culturais sem antes sensibilizar e preparar o cliente interno (pessoas que trabalham no HMI e seu ambulatório) para que as mesmas aconteçam (NEVSTROM 1996; MARIOTTI 2000: MERHY 2002). As transformações reais dentro das instituições somente ocorrem a partir dos funcionários e lideranças. Para promover uma assistência humanizada. acolhedora. o primeiro passo é sensibilizar os profissionais e prepará-los antecipadamente para a mudança. O preparo e manutenção do ambiente psicológico adequado para as mudanças é fazer com que as pessoas aprendam a aprender e inovar Sem isto, a mudança será apenas ilusória (AMICK e CELENTANO 1991: GODOY 1995: BENNIS 1999).

Porque os profissionais oferecem resistência ás mudanças?

MARIOTTI (2000) ressalta que quando se constata alguma modificação nas atividades cotidianas. nas relaçòes de trabalho, nas responsabilidades, nos hábitos $\mathrm{e}$ comportamentos dos clientes internos da organização, isto deve ser muito valorizado. 
Na não-mudança observa-se significativo volume de acomodação e de ajustamento das pessoas à rotina diária, enquanto que as transformações exigem variações e alterações nessa rotina (MARIOTTI 2000; SCHIEHLL e MORISSETTE 2000). Porém, não são todas as mudanças que impactam os profissionais, pois eles têm um limiar de sensibilidade a elas. Até certo limiar de sensibilidade, esta mudança é um evento diário e comum nos ambientes organizacionais e quase sempre passa despercebida pelas pessoas. Essas mudanças tênues podem ocorrer nos objetivos organizacionais e quase sempre são ignoradas quando ocorrem em um nivel quase imperceptivel ao cliente interno. Mas quando ela é volumosa e forte, isto é, ultrapassa o limiar de sensibilidade das pessoas. ela aguça a atenção e traz certo impacto a elas, causando-lhes preocupação, aflição e ansiedade, principalmente quando sua natureza e conseqüências são desconhecidas. Em alguns casos, provocando até o medo e pavor diante de uma situação nova e desconhecida.

Assim é a mudança percebida pelos profissionais e não a mudança real e objetiva. que determina o tipo de reação que elas irão desenvolver. Portanto, é necessário conhecer os motivos do temor e da resistência do cliente interno às mudanças que ocorrem ou precisam ocorrer nas instituições (MARIOTTI 2000; SCHIEHLL e MORISSETTE 2000).

Para que a humanização da assistência e o acolhimento ao cliente externo (usuários) ocorram. é fundamental que exista um ambiente psicológico propício. uma cultura organizacional adequada. um estímulo individual e grupal para a melhoria e para a excelência. HELOIANI e CAPITÃO (2003) demonstram que. muitos esforços para a mudança organizacional são perfeitamente bem-sucedidos. enquanto outros tendem a transformar-se em redundantes fracassos. A maioria desses esforços enfrenta vários problemas. A mudança organizacional quase sempre esbarra ou colide com alguma forma de resistència humana, não só dos funcionários, mas. inclusive, de muitos gerentes. Muitos esforços demandam muito mais tempo do que fora previsto ou desejado. enquanto outros deterioram o moral e quase sempre provocam elevado custo decorrente do tempo que os gerentes dedicam aos funcionários para convencê-los e à resoluçào de distúrbios emocionais decorrentes da mudança.

Medir a qualidade da assistência ao parto e nascimento demanda uma compreensào da multiplicidade de processos ocorridos durante todo o período da gravidez. assim como os contatos com os serviços de saúde e a ansiedade da mulher e de seus familiares de ver finalizado um processo iniciado há nove meses. As 
expectativas e ansiedades do final da gestação não são simples e deve abranger suas várias dimensões. A mulher e sua família precisam ser acolhidas pelos profissionais de saúde dentro dos principios de humanização da assistência. Para tal. eles precisam ser sensibilizados e treinados para essa modalidade de assistência.

Compreendemos que, se os profissionais de saúde se sentirem acolhidos, o aumento da cobertura e melhoria da qualidade do atendimento nos serviços de saúde disponiveis para a nossa comunidade, bem como as orientações e assistência adequadas a gestantes/parturientes e suas familia serão priorizadas para a obtenção da eficácia da assistência prestada pela instituição e para a redução da morbidade e mortalidade matema e neonatal.

Portanto. o propósito do nosso estudo é, por meio de um conjunto de critérios e procedimentos técnicos, entre eles a pesquisa do clima organizacional no $\mathrm{HMI}$ e seu Ambulatório sob o ponto de vista do cliente interno, analisar os profissionais que atuam direta ou indiretamente nos cuidados a gestante, parturiente e recém-nascido, buscando recuperar as diretrizes da assistência integral da saúde da mulher e seu filho.

A partir da premissa do relacionamento adaptativo da instituição de saúde ao meio ambiente externo e à política de humanização da assistência propomos. neste estudo colaborar com a eficiência dessa adaptação. Apresentamos, a partir do estudo de caso do HMI e de seu ambulatório, a dinâmica da mudança ambiental, seu impacto sobre a instituição e o conseqüente processo de implantação da humanização da assistência materno-neonatal de acordo com as normas de qualidade baseado nas evidências cientificas. 


\section{ANÁLISE CRÍTICA DA LITERATURA}

\subsection{Apropriação do parto pelos médicos}

A partir de meados do século XVII, os homens iniciaram a tarefa de atender as gestantes e os partos, deslocando paulatinamente as parteiras, curiosas e "bruxas ', que durante milênios foram às únicas "cuidadoras de mulheres" no momento de parir. Era a "vingança" daqueles que durante milênios estiveram alijados do milagre. Agora os homens também seria co-criadores. Era a "couvade" (mecanismo pelo qual os homens se "apoderam" do nascimento nas culturas primitivas, como os índios brasileiros por exemplo) se manifestando de forma avassaladora. Mais do que os homens, o "masculino" entrava no mundo das mulheres, trazendo com ele as luzes da razão, na tentativa de iluminar o obscuro e até então impenetrável mistério do nascer (BARBAUT 1990: JONES 2002).

Os homens, antes espectadores atônitos e amedrontados, tornavam-se aos poucos condutores do processo. De acordo com DAVIS-FLOYD (1992), RIESCO (1994) e JONES (2002), as mulheres passaram de protagonistas a assistentes passivas como auxiliares dos médicos ou como próprias parturientes.

A partir de então não seria mais a natureza, com seus mistérios e incertezas, a conduzir o processo; a razão assumiria as rédeas (DAVIS-FLOYD 1992). Com isso muitas vidas poderiam ser salvas pelos homens, muitas mulheres deixariam de morrer: muitas crianças seriam retiradas heroicamente do seu destino cruel pelas mãos ou instrumentos (fórceps) que foram criados pelos irmãos Chamberlen. na Inglaterra. sendo mantido escondido dos olhares de curiosos, por ser uma ferramenta tão importante. a ponto de ser alvo da cobiça de concorrentes (NEME 2000).

\subsection{Conseqüências do excesso de tecnologia no parto e no nascimento}

Nos dias atuais quase todos os partos são feitos em hospitais, estando as mulheres apartadas do seu ambiente e da sua família. O nascimento deixou de ser um evento cultural. da família, para se tornar um acontecimento médico. Rituais médicos e tecnológicos substituíram os tradicionais como forma de administrar o processo de nascimento. Segundo a tese da medicalização, médicos tendem a oferecer soluções biomédicas e técnicas em situações, antes consideradas como partes inerentes e integradas a vida cotidiana como a gravidez e o parto. Em relação a esses fenômenos. 
especificamente. o processo de medicalização implicou profundas transformações, não apenas no modo como os procedimentos são administrados, mas principalmente na maneira como são compreendidos e vivenciados pela maioria das mulheres.

A noção de que era possivel controlar o nascimento começou, então, a se firmar na consciência popular. Isso não significa que apenas obstetras tivessem atitudes intervencionistas durante o parto. Há evidências de que parteiras utilizavam outras práticas como versões, dilatação digital da cérvice, ruptura de bolsa e ervas para aumentar a dilatação do colo. Ressalta-se assim que o parto realizado por parteira não é necessariamente mais "natural" do que um mesmo realizado por um médico. O que ocorreu com a medicalização foi a redefinição do parto - na biomedicina - como inerentemente problemático, exigindo a presença do médico e sua ativa intervenção para garantir um bom desfecho (RIESCO 1994; WAGNER 1994; WILHEIM 2003).

Nos dias atuais a intervenção passou a ser a regra. Na classe média das grandes cidades os indices de cesariana chegam a ultrapassar 70\% (RATTNER 1996). Nos partos normais muitas pacientes usam medicações potencialmente perigosas para os fetos (WILHEIM 2003). A analgesia do parto tornou-se um tabu nos grandes centros médicos (JONES 2002). A intolerância com as práticas não-ortodoxas tem aspectos de perseguição religiosa. A jornada tecnológica chega aos dias de hoje na obstetrícia da mesma forma que muitas outras experiências humanas (JONES 2002).

Conforme JONES (2004) nossa medicina obstétrica iatrocêntrica (centrada na figura do médico). etiocêntrica (centrada na patologia e na doença) e nosocomial (que privilegia os hospitais como centros onde se busca a saúde) não consegue oferecer a feminilidade que o parto reclama.

Com base na concepção de assistência que defendemos, qualquer intervenção sobre a fisiologia só deve ser feita quando se prova ser mais segura e/ou efetiva que a não-intervenção. Com o avanço dos estudos na humanização da assistência. a argüição sobre segurança e eficácia estende-se virtualmente a todos os procedimentos de rotina na assistência ao parto e nascimento (CFM 1997; CREMESP 1997).

As tentativas de melhorar a qualidade da assistência ao parto e nascimento tanto em paises desenvolvidos como nos em desenvolvimento. muitas vezes levaram à adoção "sem criticas" de intervenções inapropriadas, desnecessárias e às vezes arriscadas, sem a devida avaliação da efetividade ou segurança destas intervenções (NOTZON 1990; ATALLAH e CASTRO 1997: CAMANO 1999; DINIZ 2001: MORAES ARAÚJO 2005). 
Diante do exposto é mais do que óbvio que a atenção à mãe, ao feto e ao recémnascido merece revisões e uma reflexão profunda e responsável das autoridades e das áreas formadoras de opinião no setor de saúde.

\section{3 "Amigas da parturiente" (Doulas): parceiras na humanização da assistência materno-neonatal}

Desde os primórdios da humanidade foi se acumulando um conhecimento empírico. fruto da experiência de milhares de mulheres auxiliando outras mulheres no momento do nascimento de seus filhos. Com a hospitalização do parto, as mulheres desenraizadas e isoladas, perderam esse apoio psicossocial tradicional e milenar acumulado pela experiência humana e que com os progressos científicos contemporâneos foi sendo substituído pelo frio cenário do parto hospitalar (DAVISFLOYD 1992).

Todavia. vivemos um momento onde os profissionais de saúde percebem a urgente necessidade de uma nova postura profissional que concilie novas demandas como a humanização da assistência, tanto por parte do usuário (cliente externo) quanto do cliente interno (funcionários) e da administração hospitalar.

A impessoalidade dos partos realizados em hospitais, associado ao crescente intervencionismo médico e o isolamento das gestantes, propiciou o surgimento das atividades das Doulas. um novo papel na comunidade com profundas raízes em práticas tradicionais. Doula é uma palavra grega que significa "serva da mulher", ou alguém que age em auxilio de uma outra pessoa. A palavra grega doula começou a ser utilizada a partir das pesquisas de KLAUSS e KENNEL (1997) no inicio da década de 90 para designar aquelas mulheres capacitadas para brindar apoio continuado a outras mulheres (e aos seus companheiros e/ou outros familiares), proporcionando conforto físico, apoio emocional e suporte cognitivo antes, durante e após o nascimento de seus filhos. A Organização Mundial da Saúde (OMS) e o Ministério da Saúde de vários países, entre eles o Brasil (Portaria 28 de maio de 2003), reconhecem hoje. após uma década de pesquisas científicas. a enorme contribuição da presença da doula no trabalho de parto e parto. momentos tão significativos e de tão profundas repercussões futuras. Tem se demonstrado que o parto evolui com maior tranqüilidade. rapidez e com menos desconforto e complicações tanto maternas como fetais. O parto torna-se uma experiência gratificante. fortalecedora e favorecedora do vínculo mãe-bebê. As 
vantagens também ocorrem para o sistema de saúde que, além de oferecer um serviço de maior qualidade, pode ter uma significativa redução nos custos dada a diminuição das intervenções médicas e do tempo de internação das mães e dos bebês.

A decisão de ter ou não uma "amiga da parturiente" (Doula) no parto cabe unicamente à mulher, sendo que ao hospital cabe fazer com que essa presença seja garantida e harmônica com as normas de humanização locais.

\subsection{Centro de Parto Normal e Nascimento: onde os partos e nascimentos humanizados acontecem}

Trata-se de uma nova modalidade de assistência à mulher durante o parto e nascimento em um Centro de Parto Normal (CPN) com a presença de acompanhante em sistema Pré-Parto. Parto e Puerpério Imediato (PPP). É importante sensibilizar o cliente interno quanto às estratégias, vantagens, desafios e avaliação desse modelo assistencial no âmbito do Sistema Único de Saúde (SUS).

O Ministério da Saúde, em 5 de agosto de 1999, publicou a Portaria Ministerial n. 985 que cria o CPN no âmbito do SUS, estabelecendo critérios para implantação e definindo recursos humanos necessários, área física. equipamentos mínimos, atribuições e competências (MINISTÉRIO DA SAÚDE 2001a).

Mais recentemente, o Ministério da Saúde publicou o Programa de Humanização ao Pré-natal e Parto a ser implantado em articulação entre as Secretarias Estaduais e Municipais de Saúde, tendo como objetivo: ações de promoção, prevenção e assistència à gestantes e recém-nascidos, ampliando o acesso, melhorando a qualidade e da capacidade instalada da assistência obstétrica e neonatal, bem como sua organização e regulação no âmbito do SUS (MINISTÉRIO DA SAÚDE 2000).

Tais medidas representam um estímulo à prática do parto normal, pois ampliam as condições para sua realização. Ao deixar de ser um "procedimento médico exclusivo". o parto passa a ser encarado como um trabalho em equipe (SCHIRMER 2000). segue filosofia assistencial materna e perinatal baseada em práticas humanizadas de caráter inovador. tendência atual na atenção ao parto e nascimento.

Dentro deste contexto atual de aculturação do processo de parto no Brasil. no qual a mulher acredita não ser capaz de dar à luz sem intervenções de rotina. é saudável que se proporcione assistência à mulher e ao recém-nascido em Unidade de Obstetricia 
e Neonatalogia. composta pelo CPN, pelo Alojamento Conjunto, pelo Centro Cirúrgico Obstétrico (CCO) e pela Unidade de Terapia Intensiva Neonatal (UTIN).

O CPN planejado para o hospital será uma unidade de atendimento ao parto normal que localizará fora do Centro Cirúrgico Obstétrico $(\mathrm{CCO})$ e com infra-estrutura fisica destinada a receber a mulher e o(a) acompanhante de forma acolhedora. $\dot{E}$ composto por uma sala de parto que contém mesa cirúrgico-ginecológica, berço aquecido, equipamentos e materiais para prestar assistência imediata ao recém-nascido (RN) e à mulher em caso de urgências. Inclui, ainda, quartos de Pré-parto, Parto e Puerpério Imediato, denominados sistema PPP.

O sistema PPP tem a finalidade de possibilitar conforto, escolha da posição de parto e atuação conjunta de todos os atores (a mulher, o acompanhante, a enfermeira obstetra. o médico obstetra, o médico neonatologista e a auxiliar de enfermagem) nesta nova "cena do parto normal".

A assistência humanizada referida é definida por BASILLE et al. (2002) como: um conjunto de condutas e protocolos que visam reduzir a morbimortalidade materna e perinatal utilizando tecnologia apropriada para o parto e nascimento.

\subsection{Clima organizacional}

A palavra clima origina-se do grego Klima e significa tendência, inclinação.

Assim. clima organizacional refletiria uma tendência ou inclinação relacionada ao atendimento das necessidades da organização e ao mesmo tempo das necessidades dos seus colaboradores, aspecto que é indicador da eficácia organizacional (LUZ. 1995: KRAY'. 1999. 2000; ALVARÃES. 2002).

Clima organizacional é o resultado de como os membros de um grupo. organização ou instituição percebem o ambiente em que trabalham. (LITWIN e STRINGER 1968; TOLEDO e MILIONI 1986: AMICK e CELENTANO 1991; NEWSTRON e JOHN 1996; BENNIS 1999; MARIOTTI, 2000; SCHIEHLL e MORISSETTE 2000). Como referem vários autores, o clima organizacional não é uma simples lista do que os membros de uma instituição gostam ou não gostam. É também uma descrição meticulosa de como funcionam as organizações. Os subsidios fornecidos pela Pesquisa de Clima Organizacional funcionam como um mapeamento das percepçòes sobre o ambiente interno a organizaçào, podendo ser um importante ponto de partida para mudanças e desenvolvimento organizacional (AMICK e CELENTANO 1991: MARIOTTI 2000). São aspectos extrínsecos como beneficios. reconhecimento 
profissional, relacionamento da equipe, incluindo a chefia, entre outros aspectos que formam os elementos básicos do que é chamado de clima organizacional e que resultam no nivel de satisfação ou insatisfação dos funcionários com o trabalho (FLOOD 1999; MARIOTTI 2000; SCHIEHLL e MORISSETTE 2000).

Segundo MARIOTTI (2000), clima organizacional é o modo como as pessoas se sentem no cotidiano de um grupo, organização ou instituição. Tal sentimento resulta de uma combinação de vários fatores: expectativas de futuro, histórias compartilhadas, regras tácitas (implícitas) de conduta. Dito de outra forma: clima organizacional é um conjunto de crenças (muitas delas inconscientes) que influenciam as ações, as percepções e o modo como as pessoas se comunicam num grupo, organização ou instituição.

Ainda segundo o autor, a pesquisa do clima organizacional é hoje aceita como de grande importância para que as instituições se dêem conta do modo como seus componentes as percebem e como tal percepção influencia seus sentimentos. emoções, comportamentos e desempenho laborativo.

Dessa maneira. o levantamento do clima organizacional de um grupo, organização ou instituição é útil não apenas como meio de diagnóstico, mas também de acompanhamento da evolução das mudanças organizacionais. Trata-se de um instrumento valioso para identificar situações e oportunidades de mudança para melhor, e avaliar a eficácia dos métodos e técnicas de mudança organizacional. Nas empresas, por exemplo. ele é em especial, importante para processos de gestão estratégica. como o balanced scorecard (cenário balanceado) (FLOOD 1999: MARIOTTI 2000).

O diagnóstico e o acompanhamento do clima organizacional colabora na diminuição dos conflitos (MARIOTTI, 2000).

Assim, quando se faz o seu diagnóstico, o que se obtém é um misto de estados subjetivos e descrições objetivas. Esse aspecto é importante. pois confirma uma das descobertas fundamentais da ciência cognitiva: não existem percep̧̧ões só objetivas nem apenas subjetivas: toda percepção resulta da interação entre o indivíduo e o mundo. onde é evidente. estão também outros indivíduos (MARIOTTI 2000).

Existem vários instrumentos para a avaliação do clima organizacional. Todos eles. porém. têm caracteristicas compartilhadas. Com efeito. o que importa não é só o instrumento a ser utilizado. mas também - e principalmente - um ponto básico: o diagnóstico deve ser feito de modo mais livre e participativo possível. 
Não desconhecemos o que aponta alguns estudiosos sobre a Pesquisa de Clima Organizacional como a International Survey Research Corporation que seleciona sete perigos em qualquer pesquisa organizacional como: 1) má escolha do momento; 2) pesquisar a totalidade da organização, em vez de usar uma amostra representativa; 3 ) fazer pesquisa com demasiada freqüência; 4) utilizar métodos super-simplificados; 5) utilizar pequeno número de pessoas para o relatório; 6) atrelar os resultados a bônus por desempenho; 7) estabelecer objetivos arbitrários para a pesquisa.

Para MARIOTTI (2000), o diagnóstico do clima organizacional é realizado sobretudo por meio de uma dinâmica de grupo. Todos os passos, desde a coleta de dados. até sua tabulação, interpretação, elaboração do relatório final e conclusões, são feitas por todos os participantes. O princípio básico é o que o observador participa de modo ativo daquilo que observa, incrementando os beneficios do diagnóstico do clima organizacional como a facilitação da proatividade (MARIOTTI 2000). Neste método não há separação sujeito-objeto. O grupo é, ao mesmo tempo, o aplicador da técnica e o objeto sobre o qual ela é aplicada. A transparência é total. Não há "caixas pretas". A atitude pró-ativa é também útil para antecipar dificuldades e conflitos, o que facilita muito a adoção de medidas preventivas.

Observa-se nítida melhora do comprometimento compartilhado. Os membros da organização percebem que sua participação é efetiva, democrática e valorizada. Os trabalhos de vários autores como DOUGLAS (1986), BAREMBLITT (1992), BRINKERHOFF e GILL (1994), FLOOD (1999), MARIOTTI (2000) e HELOIANI e CAPITÃO (2003) mostram que em organizações em que se fazem diagnósticos periódicos de clima organizacional os índices de satisfação no trabalho são sempre superiores à média.

A comunicação é fortalecida. O diagnóstico participativo, no qual todos são ouvidos em igualdade de condições ajuda a construir e manter redes de conversação consistentes. que são fundamentais para atenuar o principal problema das instituições: a compartimentalização e o bloqueio de fluxo de informações. É importante notar que a construção e a manutenção de um clima organizacional positivo desempenha um papel crucial na seguinte circularidade produtiva: 


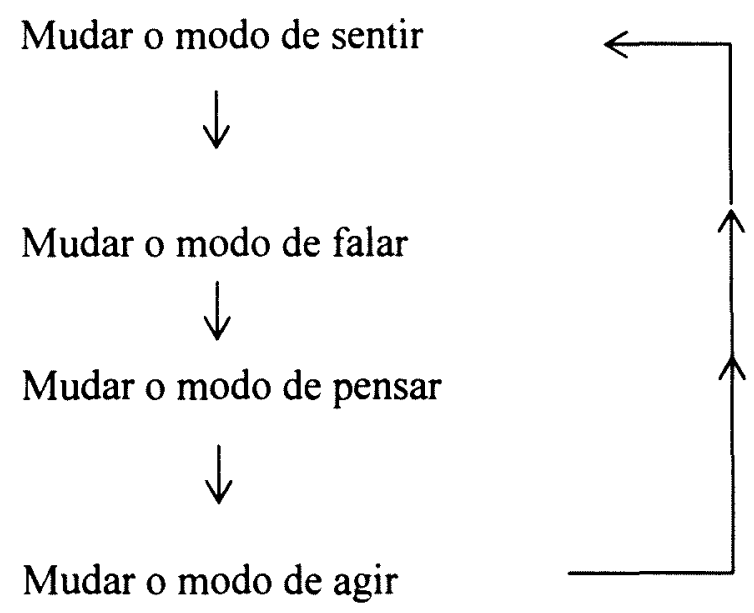

Os autores que escrevem sobre clima organizacional destacam sempre este ponto: qualquer grupo, organização e instituição que realize esse diagnóstico, deve ter bem claro que precisa atuar em relação tanto aos resultados positivos quanto aos negativos (DOUGLAS 1986; BAREMBLITT 1992; BRINKERHOFF e GIL 1994; FLOOD 1999; MARIOTTI 2000, HELOIANI e CAPITÃO 2003).E, os funcionários precisam estar realmente sensibilizados para a reconstrução do ambiente interno.

\subsection{Preparando o cliente interno para as mudanças}

De acordo com MELCHIOR (2003), o primeiro passo na avaliação é definir o objeto que será avaliado - a dimensão da realidade que será abordada e quais os critérios de julgamento que serão utilizados. Como em toda pesquisa científica é impossivel fazer uma abordagem de todos os aspectos da realidade em um só momento tendo em vista que esta realidade pode ser lida e analisada de diferentes modos.

É inóquo pretender fazer mudanças organizacionais ou culturais sem antes preparar as pessoas para fazer com que essas aconteçam (AMICK e CELENTANO 1991). As mudanças reais dentro das instituições somente ocorrem a partir do cliente interno. Para fazê-la dentro da organização, promovendo uma assistência humanizada. acolhedora o primeiro passo é sensibilizar os profissionais e prepará-los antecipadamente para tal. e esse é o papel de todas as lideranças, dos responsáveis pela implementaçào da mudança. Preparar o ambiente psicológico adequado para a mudança e fazer com que as pessoas aprendam a aprender e inovar. Sem isto, a mudança será apenas ilusória (AMICK e CELENTANO 1991; MARIOTTI 2000).

Contudo o grande obstáculo e a dificuldade maior é que a maioria dos 
administradores e gerentes está acostumada a trabalhar com a atenção voltada para assuntos físicos e concretos. Com dados previsíveis, determinísticos e de compreensão lógica. Isto é. sabem lidar com extrema facilidade e perícia com coisas reais e palpáveis, sejam elas máquinas, equipamentos, materiais, computadores, produtos, serviços entre outros. Porém, tem enorme dificuldade e impericia em lidar com pessoas. Justamente é nessas questões que residem os maiores problemas para fazer acontecer a mudança dentro das instituições. As diretrizes tomadas pela alta administração no sentido de mudar e de humanizar os serviços de saúde esbarram quase sempre com uma grande inabilidade do campo de fazer o acolhimento acontecer por meio dos próprios funcionários. E apesar da forte vontade de mudar, a mudança simplesmente não acontece. Culpa das pessoas? De quais?

$\dot{E}$ consenso que toda mudança em uma organização representa alguma modificação nas atividades cotidianas, nas relações de trabalho, nas responsabilidades. nos hábitos e comportamentos das pessoas que são os membros da organização (AMICK e CELENTANO 1991; LUZ 1995; MARIOTTI 2000; HELOIANI e CAPITÃO 2003). Para que a mudança seja dinamizada, é fundamental que exista um ambiente psicológico propicio, uma cultura organizacional adequada, um estímulo individual e grupal para a melhoria e para a excelência. Muitos esforços para a mudança organizacional são perfeitamente bem-sucedidos, enquanto outros tendem a transformar-se em redundantes fracassos. A maioria desses esforços enfrenta vários problemas. Muitos demandam muito mais tempo do que fora previsto ou desejado. enquanto outros deterioram o moral e quase sempre provocam elevado custo em termos do tempo que os gerentes dedicam às pessoas para convencê-las e à resolução de distúrbios emocionais decorrentes da mudança. Algumas organizações nem se atrevem a iniciar esforços de mudança pelo simples fato de que os gerentes envolvidos têm receio de se mostrar incapazes de executá-las com sucesso. Isso se deve aos esforços de mudança organizacional que quase sempre esbarram ou colidem com alguma forma de resistência humana. não só dos funcionários em geral, mas inclusive de muitos gerentes.

As pessoas podem aceitar as mudanças de maneiras diferentes. Podem aceitá-las positivamente e adotar uma postura de simples aceitação quando movidas pelos argumentos da direção da empresa ou quando adotam uma postura pró-ativa em que não apenas as aceitam. mas também tomam a iniciativa pessoal de fazê-la acontecer. Por outro lado. as pessoas podem comportar-se negativamente em relação às mudanças que ocorrem na instituição. Elas podem mudar porque são coagidas. como podem 
acomodar-se à mudança, habituando-se a um comportamento rotineiro e cotidiano, podem também apresentar comportamento de defesa para manter o status quo ou ainda tentar obstruir de maneira velada ou aberta qualquer tentativa de mudança dentro da empresa.

A resistência à mudança pode ser conseqüência de aspectos lógicos, psicológicos ou sociológicos (AMICK e CELENTANO 1991; MARIOTTI 2000; SCHIEHLL e MORISSETTE 2000; DESLANDES 2004).

A resistência lógica decorre do tempo e do esforço requeridos para se ajustar à mudança. incluindo novos deveres do cargo que precisam ser aprendidos. Estes são os reais custos impostos às pessoas. Quando se acredita que a mudança será favorável a longo prazo para as pessoas, elas certamente pagarão o investimento a curto prazo.

A resistência psicológica relaciona-se as atitudes e sentimentos e elas podem sentir medo do desconhecido, desconfiar da liderança do gerente ou perceber que sua segurança no trabalho está ameaçada. Mesmo que a organização não creia que haja justificativas para esses sentimentos, eles devem ser reconhecidos como reais (AMICK e CELENTANO 1991).

A resistência sociológica relaciona-se aos interesses de grupos e valores sociais envolvidos. Os valores sociais são poderosas forças no ambiente e devem ser cuidadosamente considerados. Existem coligações políticas, valores sindicais opostos e valores de diferentes comunidades que podem afetar o comportamento das pessoas. No nivel de pequenos grupos, por exemplo, existem colegas de trabalho que podem ser demitidos por causa de mudanças. As pessoas podem indagar se a mudança é consistente com seus valores sociais ou se elas mantêm o espírito de equipe (AMICK e CELENTANO 1991).

Algumas mudanças conseguem abranger conjuntamente os aspectos lógicos, psicológicos e sociológicos referidos, provocando enorme potencial de resistência por parte das pessoas envolvidas. Quase sempre, o segredo é evitar que os três tipos de resistência cresçam juntos, para que se possa atuar sobre apenas um deles. Existem várias estratégias para contornar essa resistência à mudança e aproveitar a força contrária dela a favor da inovação que se pretende instalar (AMICK e CELENTANO $1991)$. 


\subsection{Contornando resistências}

Existem várias estratégias para contornar as resistências entre elas:

\section{- Educação e comunicação}

É consenso entre os autores (AMICK e CELENTANO 1991; MARIOTTI 2000; SCHIEHLL e MORISSETTE 2000; DESLANDES 2004) que a resistência pode ser superada desde que as pessoas sejam educadas e preparadas antecipadamente para a mudança. A comunicação de idéias e do projeto ajuda os profissionais a perceberem a necessidade da mudança e a lógica inerente a ela.

\section{- Participação e envolvimento}

Ocorrem quando os agentes envolvem os resistentes em algum aspecto do projeto e da implantação da mudança e ouvem atentamente suas sugestões. A resistência é neutralizada com um esforço participativo. As pessoas envolvidas passam a participar intensamente no projeto e na implementação da mudança como sujeitos ativos e não meramente passivos. Isto representa, inicialmente, profunda mudança na filosofia e na cultura organizacional da empresa, pois a participação e o envolvimento das pessoas é uma posição eminentemente democrática (AMICK e CELENTANO 1991; MARIOTTI 2000; DESLANDES 2004).

Se os agentes de uma mudança sentem que não possuem todas as informações que necessitam para o projeto e implementação ou se necessitam do comprometimento incondicional de outras pessoas para essa finalidade, a participação e o envolvimento de mais algumas pessoas são bastante aconselháveis. A participação visa conduzir ao comprometimento e não somente à pura anuência das pessoas. $O$ comprometimento pessoal e intimo de todas as pessoas envolvidas é fundamental para que a mudança possa ocorrer e tenha pleno êxito (AMICK e CELENTANO 1991: MARIOTI 2000; DESLANDES 2004).

A estratégia de participação e envolvimento, porém. esbarra em alguns inconvenientes. Ele tanto pode conduzir a uma solução pouco eficiente devido à participação de muitas pessoas no processo, como pode consumir excessivo tempo de discussōes e troca de idéias por seu aspecto altamente democrático. Se a mudança for lenta. suave e a longo prazo, o programa de participação e envolvimento é o mais indicado. Mas. se a mudança tiver de ser rápida e urgente, esta estratégia pode retardá-la por tentar envolver profundamente todas as pessoas (MARIOTI 2000). 


\section{- Facilitação e apoio}

A resistência potencial pode ser contornada concedendo facilitação e apoio no sentido de ajudar as pessoas a se ajustarem à mudança. Esta estratégia pode incluir aconselhamento, treinamento interno nas novas funções, planos de desenvolvimento e aquisição de novos conhecimentos e novas habilidades para preparar as pessoas para a inovação. A empresa municia seu pessoal com as ferramentas e técnicas sobre como fazer a mudança e a inovação. Simplesmente, a empresa divulga entre seus funcionários a tecnologia. o saber fazer, isto é, o conhecimento da mudança. Cada gerente é instruído e educado sobre o comportamento de mudança e inovação e passa a instruir e educar seus subordinados. Com isto, o gerente transforma-se de controlador, supervisor e conseqüentemente autocrata em educador, orientador, lider, motivador, comunicador e multiplicador dos esforços de mudança (AMICK e CELENTANO 1991; MARIOTI 2000).

A estratégia de facilitação é útil quando o medo e a ansiedade estão na base da resistência. A inconveniência desta estratégia é que ela pode consumir muito tempo para preparar as pessoas e conseqüentemente ser muito cara. Se não existirem tempo, dinheiro e paciência. a utilização de métodos de facilitação e apoio deixa de ter praticidade (SCALABRIN e CASADO 2002).

\section{- Negociação e acordo}

Outra forma de lidar com a resistência é oferecer incentivos aos resistentes ativos ou potenciais para compensar a mudança. A negociação e o acordo constituem uma forma de barganha que é indicada quando fica claro que alguém vai sair perdendo com o resultado da mudança e quando seu poder de resistência é bastante representativo. Os acordos negociados evitam resistências, embora possam também envolver altos custos (AMICK e CELENTANO 1991; MARIOTTI 2000; SCHIEHLL e MORISSETTE 2000).

\section{- Manipulação e cooptação}

A manipulação em muitas situações, significará a utilização seletiva de informações e a estruturação consciente de eventos para influenciar outras pessoas.

A cooptação representa uma forma comum de manipulação. Cooptar um individuo é dar-lhe um papel desejável no projeto ou na implementação da mudança. Cooptar um grupo é dar a um de seus líderes. ou a alguém que o grupo respeita. um 
papel importante no projeto ou na implementação da mudança. Não se trata de uma forma de participação, porque os agentes não desejam receber sugestões do cooptado, mas simplesmente seu endosso ou anuência (MARIOTTI 2000).

Quase sempre, a cooptação pode representar uma forma barata e fácil de obter apoio de pessoas e de grupos. Costuma ser mais barata que a negociação e mais rápida que a participação. Porém, as desvantagens são severas. Se as pessoas sentirem que estão sendo induzidas ou manipuladas, ou que estão sendo enganadas, podem reagir de maneira negativa e criar uma resistência maior ainda. A cooptação pode ainda provocar desvios nas mudanças quando o cooptado se põe a influenciar o projeto ou a implementação das mudanças com suas próprias idéias e em desacordo com os objetivos previamente traçados (MARIOTTI 2000).

Quando não há outra alternativa, nem tempo suficiente para educar, envolver ou apoiar as pessoas, ou quando não se conta com o poder ou outros recursos para negociar, o esforço de mudança só tem a manipulação e a cooptação como meios para influenciar rapidamente as pessoas. Na realidade, a manipulação e a cooptação constituem meios abomináveis de evitar ou neutralizar a resistência à mudança (MARIOTTI 2000).

\section{- Coerção explícita e implícita}

Finalmente, a resistência pode ser tratada de forma coercitiva por meio de ameaça explícita ou implícita (como perda de cargo, de possibilidades de promoção e outros). ou efetivamente demitindo ou transferindo pessoas. Quando a rapidez é essencial e as mudanças não são populares a coerção pode ser a única alternativa. $O$ emprego da coerção é arriscado, pelo fato de que as pessoas ficam profundamente magoadas e ressentidas quando são forçadas a mudar (AMICK e CELENTANO 1991; MARIOTTI 2000).

O erro mais comum nas empresas é o de utilizar apenas uma destas abordagens ou um conjunto muito limitado delas, independente da situação. Outro erro comum é o de abordar a mudança de uma forma desarticulada e completamente desligada da estratégia que se pretende seguir. Os esforços bem-sucedidos de mudança organizacional aplicam inteligentemente algumas dessas abordagens integralmente e em combinaçòes diferentes. Os agentes da mudança empregam as abordagens com bastante sensibilidade para obter vantagens de seus pontos fortes e limitaçoes e fazem uma avaliação realista da situação (MARIOTTI 2000). 


\subsubsection{Benefícios da mudança}

A resistência à mudança não é totalmente ruim. Ela é uma reação das pessoas que pode trazer alguns beneficios. A resistência pode levar a administração da empresa a reexaminar suas propostas, e adequando-as às expectativas das pessoas envolvidas. Estas podem tornar-se os elementos críticos para que a mudança possa ser ajustada e implementada de maneira bem-sucedida. Ela pode ajudar a identificar áreas de problemas onde a mudança pode provocar dificuldades, permitindo à administração tomar as ações corretivas antes que os problemas mais sérios aconteçam. A resistência também proporciona à administração a informação sobre a intensidade das emoções das pessoas envolvidas, proporciona realização emocional dos sentimentos das pessoas e, sobretudo as encoraja a pensar e falar mais a respeito da mudança para que elas possam entendê-la melhor (MARIOTTI 2000).

A busca de uma posição competitiva favorável através de uma mudança depende de pessoas organizadas para um objetivo bem definido. E cabe não somente ao departamento de Recursos Humanos a responsabilidade de orientar essas pessoas, mas todas as gerências da instituição (MARIOTTI 2000).

Na relação do homem com o trabalho, não somente se "ganha" como também se constrói a vida, estabelecendo-se um status social que não se restringe ao ambiente fisico do trabalho. Pelo contrário, a atividade profissional é parte inexplicável do universo individual e social de cada um, podendo ser traduzida tanto como meio de equilibrio e de desenvolvimento quanto como fator diretamente responsável por danos à saúde (DEJOURS et al. 1993).

Nos estudos sobre as condições de trabalho, tem-se reconhecido cada vez mais a existência de fatores de agressão à saúde relacionada com o trabalho. Deterioração, desgaste, envelhecimento precoce são implicações das diferentes relações do homem com o seu trabalho (DEJOURS et al. 1993).

Ressaltamos. o documento oficial do Programa de Humanização da Assistência (MINISTÉRIO DA SAÚDE 2000) que inicia sua argumentação a partir de um diagnóstico de insatisfação dos usuários que diz respeito, sobretudo. aos aspectos de relacionamento com os profissionais de saúde. Essa avaliação ratifica o imaginário social e a opinião pública ao confirmar que, em "número significativo". não seriam só precários, mas desrespeitosos e mesmo violentos os cuidados dispensados nos serviços públicos de saúde. (...) Na avaliação do público, a forma do, atendimento. a capacidade demonstrada pelos profissionais de saúde para compreender suas demandas e suas 
expectativas são fatores que chegam a ser mais valorizados que a falta de médicos, a falta de espaço nos hospitais, a falta de medicamentos (MINISTÉRIO DA SAÚDE 2000). (...) Ministro da Saúde J.S, ao identificar o número significativo de queixas dos usuários referentes aos maus tratos nos hospitais (...) (MINISTÉRIO DA SAÚDE 2000).

\subsubsection{Resgatando a humanidade do atendimento}

DESLANDES (2004), refere que resgatar a humanidade do atendimento, numa primeira aproximação, é ir contra a violência, já que esta representa a antítese do diálogo, a negação do "outro" em sua humanidade. Segundo a autora, podemos destacar a humanizaçâo como oposição à violência, seja física e psicológica que se expressa nos "maus-tratos". seja simbólica, que se apresenta pela dor de não ter a "compreensão de suas demandas e suas expectativas".

No que diz respeito aos maus-tratos fisicos e psicológicos, que representam a completa e radical negação dos direitos dos usuários, sua prática é timidamente confirmada pela literatura (NOGUEIRA 1994; JEWKES e ABRAHAM 1998). Não é possivel, entretanto, afirmar o quanto essas ações são usuais ou corriqueiras. A perpetração explícita da violência parece apontar situações limite, em que são rompidos contratos básicos de sociabilidade. E, diga-se de passagem, manifestações de violência também podem ter o usuário como agressor, muitas das vezes expressando o desespero de não obter o atendimento após ter peregrinado por várias instituições, entre tantos outros motivos (PETTERSON et al. 1999; FORRESTER 2002: DESLANDES 2004).

Em contrapartida, quanto à violência simbólica do "não reconhecimento" das necessidades emocionais e culturais dos funcionários (e da imposição de certos valores morais e comportamentos), seu exercício perpassa a própria historicidade dessa organização (DESLANDES 2004).

O Plano Nacional de Humanização da Assistência Hospitalar - PNHAH (MINISTĖRIO DA SAÚDE. 2001b) destaca a importância da conjugação do binômio "tecnologia" e "fator humano e de relacionamento". Existem evidências da incoerência entre possuir boas condições de alta tecnologia e nem sempre dispor da delicadeza do cuidado. o que desumaniza a assistência. Por outro lado. se reconhece que não ter recursos tecnológicos. quando estes são necessários, pode ser um fator de estresse e conflito entre profissionais e usuários, igualmente desumanizando o cuidado. Assim. embora se afirme que ambos os itens constituem a qualidade do sistema, o "fator humano“ é considerado o mais estratégico pelo documento do PNHAH. 
(...) as tecnologias e os dispositivos organizacionais, sobretudo numa área como a da saúde. não funcionam sozinhos - sua eficácia é fortemente influenciada pela qualidade do fator humano e do relacionamento que se estabelece entre profissionais e usuários no processo de atendi mento (MINISTÉRIO DA SAÚDE 2000).

Pelo exposto, sendo a humanização do atendimento o princípio a ser alcançado para a melhora da atenção à saúde, o presente trabalho pretende analisar as condições estruturais de trabalho do HMI e seu Ambulatório sob a ótica do cliente interno, as concepções dos sujeitos sobre a humanização da assistência, trabalho em equipe interdisciplinar e o caráter coletivo deste trabalho visando, se possível, propor mudanças no modo de atendimento. 


\section{OBJETIVOS}

Analisar as condições estruturais de trabalho dos profissionais de saúde do HMI e seu ambulatório, as concepções dos sujeitos sobre a humanização da assistência e trabalho em equipe interdisciplinar, identificando, compreendendo e facilitando os processos e fatores críticos presentes na relação entre as gerencias e cliente interno, permitindo a luz dos resultados o aprimoramento do atendimento a gestante, parturiente, recém-nascido e sua família e assim colaborar na implantação da assistência humanizada ao parto e nascimento com critérios de qualidade assistencial. 


\section{METODOLOGIA}

\subsection{Quadro metodológico}

A metodologia adotada é de orientação qualitativa utilizando-se combinação das técnicas de Observação Direta dos serviços segundo TRIVIÑOS (1992) e GIL (1999), Diagnóstico de Clima Organizacional segundo MARIOTTI (2000), Grupos Focais segundo CALDER (1977) e CAPLAN (1990) e entrevistas em profundidade analisadas segundo LEFÈVRE e LEFÈVRE (2000).

A Pesquisa de Clima Organizacional foi associada após a observação direta do cotidiano de trabalho dos funcionários foi realizada para que, de posse das demandas do cliente interno se pudesse direcionar o processo de humanização da assistência. Partimos da premissa que as ações de acolhimento e humanização da assistência serão inúteis se não forem valorizadas as expressões das expectativas e demandas do cliente interno (funcionários/voluntárias) não subestimando às do cliente externo (usuário/paciente). É uma valiosa ferramenta de Gestão Estratégica pois, além de permitir a análise interna e externa, também acompanha o estado de satisfação e comprometimento dos colaboradores com a organização, proporcionando, através de estratégias e ações. o crescimento e desenvolvimento do cliente interno e a máxima produtividade e qualidade visando a consecução e a superação dos resultados préestabelecidos pela Direção.

Neste contexto. o clima organizacional busca retratar o estado de satisfação dos colaboradores em relação a diversos itens, dentre os quais podemos mencionar: ao seu trabalho, a instituição; a ele mesmo; aos colegas de trabalho, às condições de trabalho; à sua chefia/gerência. bem como visualizar e identificar o grau de alinhamento entre a cultura definida pela organização e as ações realizadas no dia-a-dia.

Dentre as principais contribuições deste Diagnóstico de Clima Organizacional, pretendemos: buscar o alinhamento da cultura com as ações efetivas da instituição; promover o crescimento e desenvolvimento dos colaboradores; integrar os diversos processos e áreas funcionais; otimizar a comunicação; minimizar a burocracia; identificar necessidades de treinamento, desenvolvimento pessoal/gerencial e de educação empresarial; otimizar as ações gerenciais, tornando-as mais consistentes; organizar. flexibilizar e agilizar as atividades da organização, dentre outras. 
$\mathrm{Na}$ maioria das vezes a própria instituição sente a necessidade de mudança, e resolve fazer a pesquisa para identificar os pontos negativos da instituição. Com base nos resultados implanta-se as ações necessárias - seja ela a necessidade de treinamento de liderança ou a melhoria na comunicação interna da instituição (GODOY 1995; KRAY 1999. 2000). Assim é possível analisar como foi o retorno e saber se as ações atenderam as expectativas (LUZ 1995; GODOY 1995; MARIOTTI 2000, ALVARÃES, 2002).

Os grupos focais são recomendados para orientar e dar referencial à investigação ou à ação em novos campos, gerar hipóteses baseadas na percepção dos informantes, avaliar diferentes situações de pesquisa ou populações de estudo, desenvolver planos de entrevistas e questionários, fornecer interpretações dos resultados dos participantes a partir de estudos iniciais, e gerar informações adicionais a um estudo em larga escala (CALDER 1997; CAPLAN 1990). Por metodologias participativas de trabalho, entende-se o emprego de métodos e técnicas que possibilitem e facilitem aos integrantes de um grupo: vivenciar seus sentimentos, percepções sobre determinados fatos ou informações. refletir sobre eles, resignificar seus conhecimentos e valores e perceber as possibilidades de mudanças (SILVA, 2002). Segundo a autora, tem ficado bem evidente que a informação. mesmo clara objetiva e adequada aos diferentes seguimentos da população. não é em si suficiente para a sensibilização pessoal. Os trabalhos realizados com grupos de pares aumentam as possibilidades de que novas atitudes e práticas sejam adotadas e modeladas por seus membros. 
O uso do grupo focal é particularmente apropriado quando o objetivo é explicar como as pessoas consideram uma experiência, uma idéia ou um evento, visto que a discussão durante as reuniões é efetiva em fornecer informações sobre o que as pessoas pensam ou sentem ou, ainda, sobre a forma como agem.

Segundo CALDER (1977) e CAPLAN (1990) duas importantes técnicas de coleta de dados qualitativos são a entrevista individual e a observação participante em grupos. O grupo focal como uma entrevista em grupo, combina elementos dessas duas abordagens. A aplicação dessa técnica permite coletar dados em curto espaço de tempo e em quantidade adequada, embora não se possa argumentar com plena convicção sobre a espontaneidade das colocações emitidas pelos participantes. Apesar disso, algumas das informações registradas pelo grupo focal serão potencialmente de grande valia, visto que dificilmente seriam coletadas através da simples observação da realidade.

Uma entrevista grupo focal envolve uma discussão objetiva conduzida ou moderada que introduz um tópico a um grupo de respondentes e direciona sua discussão sobre o tema, de uma maneira não-estruturada e natural (PARASURAMAN 1986).

$\mathrm{O}$ foco ou o objeto de análise é a interação dentro do grupo. Os participantes influenciam uns aos outros pelas respostas às idéias e colocações durante a discussão, estimulados por comentários ou questões fornecidos pelo moderador / pesquisador. Os dados fundamentais produzidos por essa técnica são transcritos das discussões do grupo, acrescidos das anotações e reflexões do moderador e de outros observadores, caso existam.

As caracteristicas gerais dos grupos focais segundo KRUEGER (1994) são: envolvimento de pessoas; reuniões em série; homogeneidade dos participantes quanto aos aspectos de interesse da pesquisa; Geração de dados; natureza qualitativa; discussão focada em um tópico que é determinado pelo propósito da pesquisa. 
Nas pesquisas qualitativas, é freqüente que o pesquisador procure entender os fenômenos, segundo a perspectiva dos participantes da situação estudada e, a partir dai situe sua interpretação dos fenômenos estudados.

De acordo com PEREIRA (2001) exercitar a crítica, a dúvida de uma realidade apreendendo-as a partir de outros conhecimentos nos possibilita produzir conhecimento, não como resultados fechados ou definitivos e sim em um processo de aproximação sucessiva à realidade que está em constante movimento, realidade dinâmica e que não se esgota.

Uma das maneiras de coletar e processar os dados obtidos das entrevistas em profundidade é por meio da técnica do Discurso do Sujeito Coletivo (LEFĖVRE et al. 2001) que busca dar conta da discursividade, caracteristica definidora, própria e indissociável do pensamento coletivo, buscando preservá-la em todos os momentos da pesquisa. ou seja na coleta, no processamento e na apresentação dos dados.

Em sua discussão sobre a delimitação da temática a ser trabalhada em pesquisa social na área da saúde, MINAYO (1998) ressalta que nada pode ser intelectualmente um problema de investigação se não tiver sido, em alguma instância, um problema da vida prática.

Encontramos na abordagem metodológica qualitativa o caminho para desenvolver esta pesquisa, na medida em que tal perspectiva proporciona abertura à apreensão da complexidade presente nas relações sociais. Evoca PEREIRA (2001) que esta metodologia permite analisar e trabalhar o objeto deste estudo com fundamentos que exigem incorporar o significado e a intencionalidade dos atos, das relações e das estruturas sociais, apostando que os trabalhadores dos serviços de saúde, a partir da operação diária de cada um, podem ser importantes sujeitos de transformação com possibilidade de (re) construção da prática da assistência à saúde marcada por uma relação acolhedora. com compromisso e responsabilização pela saúde dos usuários e desenvolvimento da autonomia destes.

A pesquisa qualitativa prevê como atitudes fundamentais: abertura, flexibilidade. capacidade de observação e de interação do pesquisador com os atores sociais envolvidos. podendo os instrumentos de coleta de dados ser corrigidos e readaptados durante a realização da investigação. Assumir tais atitudes nesta pesquisa não implicou em um menor rigor no desenvolvimento, mas sim em uma maior atenção ao objeto 
específico desta investigação, tendo por premissa que outras relações poderiam ser apreendidas no transcorrer do processo, dada a própria dinamicidade da realidade.

\subsection{Procedimentos metodológicos}

\subsubsection{Desenho do estudo}

A metodologia qualitativa foi utilizada uma vez que se pretendia trabalhar "com o universo de significados, motivos, aspirações, crenças, valores e atitudes, o que corresponde a um espaço mais profundo das relações, dos processos e dos fenômenos que não podem ser reduzidos à operacionalização de variáveis" (MINAYO 1998).

Este trabalho foi desenvolvido por meio das seguintes etapas:

1. observação direta dos serviços;

2. aplicação do questionário sobre avaliação de clima organizacional;

3. grupos focais; e

4. entrevistas individuais.

\section{Observação participativa}

No período de março a junho de 2001 a autora deste estudo realizou observação direta do cotidiano de trabalho nos seguintes setores: recepções do Hospital Maternidade Interlagos e do seu Ambulatório, Unidades de Terapia Intensiva: Neonatal e Adulto, Pré-Parto, Centro Obstétrico, Alojamento Conjunto, ambientes de espera das consultas ambulatoriais e do pronto-atendimento, ambiente das Diretorias da instituição e de seu Ambulatório.

Segundo GIL (1999), a observação participante constitui-se em um procedimento científico desde que sirva a um objetivo formulado e que esteja sistematicamente planejado, devendo ser submetida a verificação e controle de validade e precisão. As anotações de campo, segundo TRIVIÑOS (1992), são entendidas como todas as observações e reflexões que realizamos sobre as pressões verbais e ações dos sujeitos. descrevendo-as primeiro, e fazendo comentários críticos, em seguida, sobre as mesmas

A observação foi organizada em etapas a partir de um roteiro e registrada em um caderno de campo. No roteiro destas observações foi ressaltado os pontos positivos e negativos da instituição no tocante ao acolhimento e humanização da assistência. 


\section{Aplicação do questionário do Diagnóstico de Clima Organizacional} (anexo 1)

\section{Grupos focais}

Uma das etapas da pesquisa, os grupos focais (vinte e oito), foram realizados segundo CALDER (1977) e CAPLAN (1990) com duas sessões para cada grupo de profissionais,com 12 a 16 pessoas por grupo, visando levantar as expectativas, os pontos negativos e positivos da instituição e sugestões de melhoria.

Para fins metodológicos, no processo de realização dos grupos focais, foi contemplada grande parte dos funcionários do Hospital Maternidade Interlagos e seu ambulatório optando-se por dividi-los como integrantes da área administrativa ou da área assistencial. Estes grupos foram divididos em A e B, plantão par e plantão impar. A duração de cada grupo focal foi de 1 h30 à 1 h40. Todas as informações obtidas e captadas nestas atividades foram analisadas pela pesquisadora com a colaboração de uma psicóloga. Nos grupos focais foram levantados os pontos de desumanização, pontos negativos, e os pontos positivos dos diferentes setores de trabalho e da instituição como um todo e sugestões para reverter a curto, médio e longo prazo os fatores negativos e incrementar e manter os positivos.

$\mathrm{Na}$ área administrativa foram inseridas as secretárias das diversas diretorias, diretores e assessores, funcionários do Serviço de Arquivo Médico e Estatística (SAME). Recepção de Pacientes, Serviço de Apoio ao Usuário. seguranças. motoristas de ambulâncias. auxiliares de limpeza, telefonia. rouparia. zeladoria, Recursos Humanos. Os funcionários considerados como da área Assistencial foram os médicos de todas as especialidades, enfermeiras, enfermeiras obstétricas, auxiliares de enfermagem, psicólogas, assistente social, biólogo, nutricionista, farmacêutico.

Em alguns grupos focais foram estudados as atividades dos distintos grupos de profissionais. com o objetivo de analisar concepções dos sujeitos sobre o sentido da humanização da assistência, trabalho em equipe interdisciplinar e as evidências do caráter coletivo desse trabalho. Para os profissionais categorizados como da área assistencial. tomamos como referenciais teóricos um instrumento de Humanização do Ministério da Saúde (2001a) intitulado "Parto, aborto e puerpério: assistência humanizada à mulher e. Princípios da Política Nacional de Ciência, Tecnologia e 
Inovação em Saúde", 1994 e demais textos de Apoio sobre Acolhimento como Programa de Humanização no Pré Natal e Nascimento do Ministério da Saúde (2000).

Os grupos focais realizados com os médicos de todas as especialidades do HMI e seu Ambulatório foram agendados para três sábados, tendo sido dado a opção de escolha ao profissional.Estes foram realizados no anfiteatro do Ambulatório, com maior duração pela dificuldade de agregar os funcionários médicos para realização destas atividades sendo todos coordenados por profissionais externos a instituição, convidados pela pesquisadora, um médico, uma psicóloga e uma pedagoga.

\section{Entrevistas em profundidade}

Foram também realizadas 67 entrevistas em profundidade com profissionais de cada especialidade, no próprio local de trabalho, com duração de no máximo 60 minutos. média 25. escolhidos aleatoriamente e que aceitassem participar da pesquisa, como: obstetras (6), anestesiologistas (3), neonatologistas (4), intensivistas (2), residentes (4), diretores de serviço (6), enfermeiras (7), auxiliares de enfermagem (7), psicóloga (2), assistente social (2), nutricionistas (1), funcionarias do laboratório (3), da farmácia (2), do banco de leite (2), da recepção (8), serviço de apoio ao usuário (2), seguranças (4) e motoristas de ambulância (2), sendo estas com conteúdos semelhantes para os diferentes profissionais.Foi usado como critério de definição do número de entrevistas a saturação das falas.

Essas entrevistas foram gravadas, transcritas. lidas várias vezes pela pesquisadora e posteriormente analisadas juntamente com alguns profissionais de fora da instituição como uma epidemiologista, uma psicóloga que deu apoio na análise das entrevistas e uma antropóloga. As falas foram agrupadas, segundo núcleos de sentido, construídos com base nas percepções dos atores sociais entrevistados e das observações diretas. Por se tratar de uma pesquisa sobre pensamento coletivo, procedeu-se à verificação de quanto ou em que proporção determinados atributos estavam presentes na população de estudo, em conformidade com a técnica descrita por LEFĖVRE e LEFĖVRE (2000).

A cada pergunta aberta, os discursos individuais eram estudados, confrontados. deles extraindo elementos que estivessem expressando o pensamento de uma 
coletividade, no presente caso, o cliente interno do Hospital Maternidade Interlagos e seu Ambulatório.

Posteriormente procuramos reconhecer pensamentos com sentidos comuns, o que implicou compor um discurso comum, coletivo, com discursos individuais, ou partes destes, semanticamente semelhantes ou complementares. $\mathrm{O}$ objeto do signo, neste momento do processo, conforme o descrito por LEFÈVRE e LEFĖVRE, (2000) é composto pelos conjuntos de expressões chave (ECH) - idéias centrais (IC) semelhantes ou complementares e o signo que os representa é o Discurso do Sujeito Coletivo (DSC), um discurso-síntese que reúne, em um só discurso, isto é, em um só conjunto, as expressões chave das idéias centrais semelhantes e que passa a expressar ou representar a fala do social ou o pensamento coletivo na primeira pessoa do singular.

Em síntese, na análise das falas das entrevistas em profundidade, utilizamos as Figuras Metodológicas - expressões chave, Idéias Centrais e Ancoragem -, a partir das quais foram construídos os discursos do sujeito coletivo (DSCs).

\subsubsection{Local do estudo - Hospital Maternidade Interlagos e seu}

\section{Ambulatório}

O Hospital Maternidade Interlagos (HMI) e seu Ambulatório pertencem à Secretaria de Estado da Saúde de São Paulo (SES) e atendem gestantes/parturientes de baixo e alto risco. O HMI realiza, aproximadamente, 600 partos/mês, oscilando as taxas de cesariana entre 30 e $40 \%$ do total de partos.

A área de abrangência dos serviços oferecidos pelo Hospital Maternidade Interlagos é compreendida pelo extremo sul da zona sul da capital de São Paulo, com ênfase na população da região da Capela do Socorro, atendendo também os distritos de Parelheiros e Grajaú. Esta região administrativa tem, hoje, por volta de 650.000 habitantes. onde $35 \%$ destes são constituidos por mulheres em idade reprodutiva (SMS. 2002).

Nessa região. o Hospital Maternidade Interlagos é o único equipamento público de atendimento especializado à mulher no ciclo gravídico-puerperal. Conta com 96 leitos sendo 4 deles destinados a UTI Adulto e 12 de UTI Neotatal.

Em 2003, este serviço atendeu 130.096 pessoas. 


\begin{tabular}{l|l}
\hline \multicolumn{1}{c|}{ Faixa etária } & Número pessoas atendidas \\
\hline 0 a 28 dias & 5.324 \\
\hline 28 dias a 11 meses e 29 dias & 34.560 \\
\hline Mulheres de 12 a 49 anos & 59.248 \\
\hline População entre 50 e 70 anos & 32.964 \\
\hline
\end{tabular}

O quadro acima mostra que 99.132 pessoas atendidas eram mulheres em idade fértil e menores de 1 ano.

\subsubsection{Etapas da pesquisa}

\section{O processo diagnóstico contou com as seguintes etapas:}

- Observação direta do cotidiano de trabalho em setores distintos da instituição;

- Avaliação do clima organizacional. Aplicação do instrumento diagnóstico de MARIOTI (2000) - Anexo 1; Ressaltamos que não foi pesquisado o Clima Organizacional Ideal, como os funcionários acham que a situação deveria estar, devido tempo insuficiente para preencher, o do questionário de avaliação do clima organizacional;

- Grupos focais - o cliente interno foi separado como integrante da área administrativa e da área assistencial; roteiro (Anexo 3);

- Voluntárias do HMI - no início os grupos focais com as voluntárias ocorreram separados dos funcionários e, em etapas posteriores estas puderam participar com as distintas categorias;

- Entrevistas em profundidade com profissionais de cada especialidade ou categoria, com conteúdos semelhantes para os diferentes funcionários. num total de 67 (Anexo 4);

- Análise de documentos e protocolos da instituição. 


\subsubsection{Observação dos diversos setores do Hospital Maternidade Interlagos e seu Ambulatório}

A observação foi organizada em etapas a partir de um roteiro e registrada em um caderno de campo. No roteiro destas observações foi ressaltado o ponto positivn e negativo de cada setor da instituição no tocante ao acolhimento e humanização da assistência.

\section{3 Descrição dos ambientes onde foram realizados os grupos focais e outras atividades}

Os grupos focais com os profissionais do periodo diurno tanto do ambulatório como do hospital, foram realizadas no anfiteatro do Ambulatório do Hospital Maternidade Interlagos. A sala era ampla, arejada, iluminada e limpa. O piso era de paviflex, com seis janelas grandes com persianas brancas. As cadeiras eram de plástico em forma de conchas (assentos móveis), o que facilitou muito as dinâmicas. No fundo da sala havia um quadro negro, um apagador e uma mesa grande de madeira (mógno) com quatro cadeiras.

Com relação aos equipamentos/materiais, estavam sempre disponíveis canetas, folhas de papel sulfite, pranchetas, canetas coloridas hidrográficas de ponta grossa, papel para flip chart. colchonetes, televisão, vídeo e retoprojetor.

Os grupos focais para os funcionários do periodo noturno para maior comodidade dos mesmos foram realizadas na sala de reuniões do primeiro andar do Hospital Maternidade Interlagos. O piso era de granito de cor cinza. bem arejada, com uma mesa redonda de tampo de vidro temperado e seis cadeiras. Por ocasião dos grupos focais e outras atividades esta mesa era retirada para o compartimento do lado e colocado cadeiras móveis. Estavam disponiveis colchonetes. um quadro branco. canetas para retoprojetor. apagador. canetas, papéis, pranchetas.

\subsection{Procedimentos éticos}

Essa pesquisa foi analisada e aprovada pelo Comitê de Ética da Faculdade de Saúde Pública da Universidade de São Paulo e pelo Comitê de Ética do Hospital Maternidade Interlagos - Secretaria de Estado da Saúde de São Paulo. 
No desenvolvimento desta pesquisa, foi observado critérios rigorosos quanto ao sigilo das informações e nesse sentido os riscos de constrangimento pessoal podem ser considerados mínimos.

Com relação à proteção da identidade dos entrevistados em geral, foi proposto a escolha de um nome fantasia, porém muitos entrevistados preferiram ser identificados pelos seus próprios nomes.

No primeiro momento da observação, o consentimento informado constou de uma explicação sobre a pesquisa e um formulário de consentimento informado por escrito (Anexo 2). 


\section{RESULTADOS E DISCUSSÃO}

\subsection{Clima Organizacional do Hospital Maternidade Interlagos e seu}

\section{Ambulatório}

A pesquisa do clima organizacional permitiu que fossem avaliados os seguintes parâmetros: conformismo, responsabilidade, motivação e comprometimento compartilhado, recompensas, comunicação e clareza organizacional, calor humano e apoio. verticalidade e horizontalidade.

Os resultados mais relevantes, obtidos por meio deste questionário respondido por 98 profissionais, são descritos a seguir.

O quadro abaixo resume os resultados obtidos na aplicação do questionário.

\section{Diagnóstico de Clima Organizacional do HMI e seu Ambulatório}

\begin{tabular}{|c|c|c|c|c|c|c|}
\hline \multirow{3}{*}{$\begin{array}{c}\text { Parâmetros } \\
\mathbf{N}=98\end{array}$} & \multirow{2}{*}{\multicolumn{2}{|c|}{$\begin{array}{l}\text { Alto } \\
7-10 \\
\text { Atual }\end{array}$}} & \multirow{2}{*}{\multicolumn{2}{|c|}{$\begin{array}{c}\text { Mediano } \\
4-6 \\
\text { Atual }\end{array}$}} & \multirow{2}{*}{\multicolumn{2}{|c|}{$\begin{array}{l}\text { Pouco/Nenhum ou Baixo } \\
1-3 \\
\text { Atual }\end{array}$}} \\
\hline & & & & & & \\
\hline & $\mathrm{N}^{\circ}$ & $\%$ & $\mathrm{~N}^{\circ}$ & $\%$ & $\mathrm{~N}^{\circ}$ & $\%$ \\
\hline 1. Conformismo & 69 & 71 & 16 & 16 & 13 & 13 \\
\hline 2. Responsabilidade & 70 & 72 & 21 & 21 & 7 & 7 \\
\hline $\begin{array}{l}\text { 3. Motivação e } \\
\text { Comprometimento } \\
\text { Compartilhado }\end{array}$ & 65 & 66 & 19 & 20 & 14 & 14 \\
\hline 4. Recompensas & 72 & 74 & 19 & 19 & 7 & 7 \\
\hline $\begin{array}{l}\text { 5. Comunicação e Clareza } \\
\text { Organizacional }\end{array}$ & 14 & 14 & 81 & 83 & 3 & 3 \\
\hline 6. Calor Humano e Apoio & 27 & 28 & 25 & 25 & $\overline{46}$ & 47 \\
\hline 7. Verticalidade & 57 & 58 & 34 & 35 & 7 & 7 \\
\hline 8. Horizontalidade & 34 & 35 & 57 & 58 & 7 & 7 \\
\hline
\end{tabular}

1. Conformismo: No HMI e seu Ambulatório o grau de conformismo encontrado foi: alto $(71 \%)$. mediano $(16 \%)$ e baixo (13\%). Este item foi sinalizado pela intensidade em que os membros da instituição estavam aceitando com passividade as situações cotidianas. Enfatiza que o conformismo é mais que um excesso de subordinação: é uma espécie de resignação. uma postura pessimista e negativa. Segundo MARIOTTI (2000). em geral. ocorre em organizações em que há excesso de regras e elas são demasiado 
rigidas. $\mathrm{O}$ alto nivel de conformismo sinalizou a intensidade da resignação do cliente interno. uma postura pessimista e negativa.

2. Responsabilidade: Quanto ao nível de delegação de responsabilidade, $72 \%$ referiu pouca ou nenhuma.Como conseqüências desta deficiência de delegação de responsabilidades em relação à instituição observou-se: falta de dedicação, por insatisfação pessoal: os problemas não resolvidos eram com freqüência ignorados mas sempre voltando agravados e, significativo absenteismo setorial, sobretudo nas áreas de maiores demandas.

3. Ausências de motivação e comprometimento compartilhado: Mais da metade do cliente interno $66 \%$. referiu que o nível de motivação e comprometimento foi pequeno e somente $14 \%$ referiu como grande. Foi observado criação de compartimentos estanques ("ilhas" organizacionais); aumento da resistência a ações e práticas novas, no caso implantação/implementação da humanização da assistência materno-neonatal e a incorporação de novos membros. As chefias se desinteressavam muito pela vida pessoal dos funcionários e observou-se incremento dos boatos e intrigas de corredor.

4. Recompensas: O nível de recompensas foi: pequeno (74\%), mediano (19\%) e alto $(7 \%)$. Como as recompensas eram poucas, observou-se na organização uma atmosfera de impessoalidade e queda da doação espontânea de feedback entre os profissionais.

Foram ainda observados: incerteza sobre o que representa o trabalho; aumento da rotatividade dos membros em áreas criticas; aumento de horas extras e de trabalho; conflitos sobre autoridade e responsabilidade; falta de base para tomadas de decisão.

5. Comunicação e Clareza Organizacional: O nível de comunicação e clareza foi: baixo $(3 \%)$, mediano $(83 \%)$ e alto (14\%). Representa o grau de ordem, bom funcionamento, transparência de atitudes e clareza de definição de objetivos da instituição. 
6. Calor Humano e Apoio: O nível de calor humano e apoio foi: baixo (47\%), mediano $(25 \%)$ e alto (28\%). Esta dimensão reflete a amizade e o entendimento que devem existir na instituição. Os membros confiam uns nos outros e se apóiam mutuamente.

7. Verticalidade: $\mathrm{O}$ nível de verticalidade foi referido como: alto por $58 \%$ do cliente interno. mediano (35\%) e baixo (7\%). No início deste estudo observou-se em determinados setores excesso de hierarquia e pouca flexibilidade (verticalidade). A tendência predominante era o autoritarismo e a rigidez de posições. Certamente esta variável contribuiu para a resistência institucional à mudança e o comprometimento da qualidade assistencial. Enfatiza-se que a organização de alta verticalidade tende a entrar em entropia (auto-dissolve-se).

8. Horizontalidade: O nivel de horizontalidade foi: excessivo (35\%), satisfatório ( $58 \%$ ) e baixo (7\%). Observava-se que, em alguns setores houve predomínio da horizontalidade que representa o grau de informalidade de uma organização. Como conseqüência desta horizontalidade muitas vezes excessiva, acentuaram-se os freqüentes boatos, intrigas de corredor e ressentimentos.

\subsection{Observação dos ambientes de trabalho}

Observamos que nos distintos ambientes estudados os profissionais projetavam a perspectiva de "equipe integração". embora ainda encontram-se em situações de agrupamento, estando o Ambulatório do Hospital Maternidade Interlagos mais próximo do que denominamos "equipe integração". Também observamos que a diferença técnica dos trabalhos especializados transmutava-se em desigualdade valorativa dos mesmos.

$O$ trabalho em equipe foi emergindo como modalidade de trabalho coletivo que se configurou na relação recíproca entre as intervenções técnicas dos distintos agentes. No bojo da relação entre trabalhos e interação os profissionais construíam consensos que configuravam projeto assistencial comum. desprovidos de significativos pontos de humanização dos relacionamentos e da assistência. em torno do qual deveria ocorrer a integração da equipe de trabalho.

O autoritarismo observado em certos setores de trabalho pode ter promovido o excesso de comportamentos informais, clandestinos em alguns momentos levando a 
comportamentos promiscuos pois, afinal de contas os funcionários precisam sobreviver àquele ambiente. Muitos plantões funcionavam com menos da metade dos funcionários necessários e por este e outros motivos a auxiliar de enfermagem mentia que já tinha feito a medicação no horário prescrito (pelo menos estava checado no prontuário da paciente) e em alguns momentos a pesquisadora pode confirmar que esta ou não tinha sido feita ou realizada muito além do horário prescrito. Este é um dos exemplos de comportamento defensivo mas que não deixa de ser cínico.

Em certos momentos ficou evidente uma alienação política gerada dentro da organização. Os profissionais não tinham a menor consciência dos processos dos seus trabalhos.

O conformismo exagerado gerava uma falta de comprometimento. de adesão por parte de muitos funcionários. Quando foi apresentado o Programa de Humanização da Assistência do Ministério da Saúde, foi grande o desinteresse e muitos alegaram "é mais um programa. claro que aqui nada para implantado porque aqui nem espaço fisico temos".

A comunicação inadequada observada em diversos setores revelava a diversidade de entendimento sobre os processos de trabalho. Não seria necessário somente as normas estarem bem claras, bem elucidadas no papel pois continuariam os problemas de comunicação. Os valores da organização como meta. missão, são incorporados de modos diferentes pelo cliente interno apesar do discurso ser o mesmo.

\subsection{Grupos focais}

Para se analisar os discursos dos grupos focais, separamos as falas nos aspectos que mais se sobressaíram na análise.

Assim eles foram agrupados em seis categorias: 1) Interação profissional; 2) Infra-estrutura: 3) Comunicação e integração entre os funcionários: 4) Quadro pessoal; 5) Treinamento e organização do trabalho; 6) Direitos dos usuários. Esses itens serão abordados em partes. sendo apresentados seus pontos negativos. positivos e as sugestões dos funcionários. 


\subsubsection{Pontos negativos}

\subsubsection{Em relação à interação profissional}

Vários profissionais, principalmente os não médicos, referiram que não são respeitados como profissional pelos seus colegas de trabalho e seus superiores. $\mathrm{O}$ discurso abaixo reflete bem esta questão.

"Ninguém mais respeita o auxiliar de enfermagem. Nós estamos ao lado da paciente desde o momento da sua internação, do nascer, até a morte, nas suas complicações (quando eles mais precisam), na sua angústia e na sua depressão, mesmo assim estamos ali, trabalhando e dando todo apoio, sendo contratado ou efetivo, sendo que o funcionário contratado trabalha muito e não é reconhecido, porque não pode nem se quer fazer alguma queixa, porque: Olha seu contrato não vai ser renovado. Isso é descriminação, falta de alma e desumanização. Os auxiliares não têm oito folgas enquanto que os enfermeiros têm. Falta acolhimento entre os companheiros de trabalho e de humanização com os pacientes. As colegas faltam e não avisam, não tem consideração pelos colegas do plantão. É aconselhável a presença constante do médico no consultório".

(...) "Há muita falta de educação dos médicos com os auxiliares. Os médicos me chamam a atenção na frente de funcionários".

"Gostaria que as nossas chefias (as enfermeiras) tivessem mais consideração com os auxiliares. Chamam a atenção da gente na frente dos demais funcionários. Sinto descriminação também por parte dos médicos".

"Que as enfermeiras tenham autonomia quanto aos auxiliares e equipe em seus setores. Porque os contratados não têm férias, temos que ficar a implorar por pequenas folgas. Seria bom se as enfermeiras viessem às oficinas de humanização".

"Por que a chefia folga 8 dias ao mês e o mês de 31 dias perdemos uma folga, folgando apenas 5 plantôes? Nós auxiliares de enfermagem, de um modo geral, sentimo-nos abandonados por todas as chefias. Gostaria que 
as enfermeiras dessem uma atenção mais diferenciada para o periodo noturno. Desde que o hospital existe o periodo noturno tem ficado em segundo plano".

"Por que ameaçar tirar o Prêmio Incentivo? Tem que parar com as ameaças de tirar o Prêmio Incentivo. Somos pessoas adultas".

"Desde que o hospital existe o periodo noturno tem ficado em segundo plano".

"Nosso problema é que somos válvula de escape, achando que o DP tem culpa de todos os problemas, principalmente financeiros, onde poucas pessoas reconhecem e agradecem os funcionários do DP".

"A imagem e as considerações que transparece, no caso do pessoal da segurança e limpeza, como algo terceirizado. Algo que esta junto, mas não faz parte. Isso passa uma sensação de inferioridade, de se ter menos direito".

Estas frases retratam bem o descontentamento dos funcionários em relação a chefia e subordinados.

"Chefias ausentes, que não prestigiam o trabalho do subordinado".

"Precisamos de mais atenção e proteção da chefia, pois dá a entender que estamos esquecidos".

"As enfermeiras tem que ter um pouco mais de paciência para conosco".

\subsubsection{Em relação à infra-estrutura}

Outro ponto negativo refere-se à infra-estrutura hospitalar dificultando o atendimento das usuárias com dignidade.

"O chuveiro do pré-parto não funciona normalmente. às vezes esquenta às vezes não. No pré-parto, falta espaço fisico, a maioria das vezes recebo as gestantes vindas do PS e não tenho onde acomodá-las. As mães 
com esse frio nos corredores e nas macas, e os chuveiros frios. As macas estão em péssimo estado, são duras e quebradas. Mais berços aquecidos, pois temos apenas três, sendo que só dois funcionam, porque um está sempre quebrado. O elevador está sempre quebrado. $\dot{E}$ desumano ter que pedir receita para cada refeição de paciente. A nutricionista acaba de passar e chega nova paciente. $O$ espaço da reanimação do $R N$ é muito pequeno. Falta posto, conforto e vestiário para enfermagem. Não tem banheiro. nem armário para guardarmos as bolsas. Não tem lanche para funcionária da limpeza e para os seguranças ".

"O ambiente fisico do pré-parto precisa ser totalmente reformado".

"Colocar mais um elevador, pois o que desce a roupa suja e o lixo também sobe a alimentação. Roupas com mais qualidade e carinho para nossos RNs. Os cobertores parecem lixas, os pagãozinhos são reaproveitados dos uniformes velhos verdes, do C.O e nem têm fitinhas para amarrar as aberturas das blusinhas".

"Faltam fraldas. Não concordo com os RNs ficarem sem fraldas".

“A estrutura fisica no setor dificulta a privacidade, faltam divisórias nos setores. É necessário melhores condições para o atendimento, melhores equipamentos".

"Não temos um vestiário decente para gente mudar a roupa, tomar um banho. É necessário banheiro feminino e masculino com armários para todos os funcionários. Macas com condições de uso e se possivel um transfer (não custa caro) ".

"Nas ambulâncias faltam equipamentos de primeiros socorros. Ex:

prancha, colar cervical. No PS falta também equipamento e área própria para atendimentos imprevistos".

Até as questões alimentares foram percebidas como problemas importantes de infra-estrutura. 
"Melhorar a quantidade de mistura na cozinha. Queremos um lanche melhor".

E referem também os problemas de infra-estrutura até para conforto do profissional.

"Falta espaço para tomar café. O café da noite vem fervido na garrafa. Elas vêem sujas por dentro".

"Falta chuveiro para os funcionários. Falta conforto para a enfermagem. Falta uma salinha de conforto no CO para a enfermagem. não só para o médico, porque também somos humanos; lugar para fumante, pois à maioria usa a escada para fumar, incluindo o médico".

"Não existe recreação para os funcionários e nem creche para os filhos dos mesmos".

A fala que segue é emblemática em relação a deficiência da infra-estrutura, ela desvela a peculiaridade da instituição que absorve a demanda de outros hospitais públicos como: Hospital Municipal do Campo Limpo, Hospital Grajaú, Hospital Zona Sul e Hospital Pedreira. que em determinados períodos suspenderam a internação para reforma no berçário e/ou Centro Obstétrico.

"Não concordo com tantas puérperas que ficam nos corredores em macas após o parto, atrapalhando até o nosso andamento no corredor. pois são muitas macas e berços e as puérperas e os RNs são os que mais sofrem naquelas macas, são muito mal acompanhadas e ficam reclamando com os auxiliares. Falta de condições para acomodar as puérperas e RNs".

Apesar da peculiaridade da infra-estrutura, os funcionários sentem-se gratificados quando a população refere. apesar de tudo, a confiança na instituição. 
"Aumentar as enfermarias, pois fica dificil para irem ao banheiro. Ficamos contentes quando as mães dizem: que bom ganhar meu filho aqui. mesmo no corredor, tenho medo dos outros lugares".

\subsubsection{Em relação à comunicação e integração entre os funcionários}

A falta de comunicação e integração entre os funcionários, também, foi mencionada como ponto negativo.

(...) "Melhorar a comunicação da chefia com os funcionários. Melhorar o relacionamento entre os setores" (...)

"Há falta de integração do berçário com o Banco de Leite. Ex: chega uma mãe para tirar leite e não tem uma funcionária do banco de leite, as funcionárias do berçário nunca querem atendê-la. Tiram o material do lugar e nunca põe de novo no lugar. Abrem o armário e não fecham. $\dot{E}$ preciso ter mais união entre os colegas. Há falta de informação para os funcionários. Ex: você chega no Berçário e pergunta alguma coisa, ninguém sabe".

"Queremos ser tratados como gente, ser respeitados, ser compreendidos pelos demais funcionários do HMI. Gostaria que tivessem maior compreensão com os funcionários contratados".

"Precisamos que os funcionários do laboratório busquem os materiais. porque sobrecarrega os funcionários do $\mathrm{CO}$. Melhorar escala para os funcionários poderem participar dos cursos com tranqüilidade. Solicitar maior e melhor participação dos residentes. Marcar pelo menos uma reunião por mês, dando oportunidade para cada um participar com sugestões e opiniões próprias. Considerar o que cada um fala com resposta em debate. Pode-se também deixar uma caixa de sugestões e criticas para saber o melhor andamento do setor. Dar motivações para ter melhores relacionamentos, talvez investir em recursos que ajudem nessa área. Ajudar cada um a nào tolerar falar pelas costas e ajudar a pessoa a resolver a questão com a própria pessoas para não virar fofoca e tornar o ambiente de trabalho mais pesado". 


\subsubsection{Em relação ao quadro de pessoal}

Um dos pontos mais mencionados diz respeito à falta de pessoal e descriminação entre categorias funcionais da instituição.

O HMI possuia os seguintes tipos de contratos de trabalho:o profissional efetivo, o contratado de emergência (contrato 3131) e, atualmente, apresenta funcionários efetivos e os contratados porém são aqueles remanescentes de concurso (contrato 733) e que estão aguardando suas efetivações.

(...) "É preciso maior número de enfermeiras obstétricas e auxiliares de enfermagem".

(...) "Ter uma escrituraria e uma enfermeira em periodo integral. $O$ pessoal do laboratório precisaria retirar no CO (Centro obstétrico) os materiais para exame".

"Há necessidade de se ter um GO plantonista no PS para atender prontamente as parturientes. E, também tem os carros de resgate, com as emergências que chegam na porta, evitando assim a demora para descer $e$ os olhares lançados pelos acompanhantes pensando justamente o que nós pensariamos se estivéssemos do outro lado....... ".

"Mais auxiliares de enfermagem. pois há plantão muito cansativo e isto torna impossivel fazer um trabalho perfeito. Tem muitos enfermeiros $e$ poucos auxiliares".

"Não temos manutenção à noite para trocar uma lâmpada. Todas as vezes que precisamos da manutenção, o rapaz fala que está no Ambulatório do Hospital".

"Falta funcionário no nosso setor no noturno (Setor de Rouparia). pegamos muito peso, falta mais colaboração entre os colegas". 


\subsubsection{Em relação ao treinamento e organização do trabalho}

Os funcionários têm claro a necessidade de treinamento, bem como da organização ou reorganização do serviço.

"Quando a estrutura fisica estiver preparada para o parto humanizado, precisaremos de treinamento tanto para o médico como as enfermeiras obstétricas, treinamento prático e não teórico".

(...) " $\dot{E}$ preciso reeducar os Residentes. Orientação para os $R I$ sobre como proceder com a paciente".

"Falta de treinamento entre os profissionais da enfermagem. Dificil relacionamento com a enfermagem no sentido de colher informações $e$ transmitir informações. Falta de educação continuada, tanto no setor administrativo quanto no técnico. Falta compreensão entre os funcionários. Tolerância zero! Impaciência!"

"Falta treinamento para os funcionários, reciclagem pessoal. palestra para aqueles com problemas de saúde na unidade".

"Esses cursos ou oficinas precisam ser mais freqüentes porque não temos dinheiro para pagá-los fora do hospital e ajuda demais nas nossas profissões. Podiamos ter apostilas claras para melhor entender como procedem".

Queixam-se da falta de equidade e organização por parte das chefias.

"Infelizmente existem dois pesos e duas medidas. Há falta de planejamento das férias dos funcionários, assim prejudicando o andamento dos setores. Falta de organização vindo da chefia da recepção".

"Deve ficar enfermeira permanente no $C O$, para resolver problemas de escala. manutenção, etc. Reunião mensal, para se passar as últimas mudanças e soluções possiveis em todos os setores". 
"Mais organização na R.P.A, em relação aos momentos imprevisiveis de urgência com paciente (clientes) de P.O.I graves como preparo de materiais de parada cardiorespiratória. Ter mais ordem em relação às normas.

\subsubsection{Em relação aos direitos dos usuários}

Muitos funcionários, apesar de não terem conhecimento sobre o direito dos usuários quanto a presença do acompanhante, referem que esta ausência causa muito prejuizo e ansiedade às gestantes/parturirentes/puérperas.

(...) "No Alojamento Conjunto a paciente fica ansiosa aguardando a visita. noticias de casa, mas embora em horários restritos ela pode receber a familia e amigos enquanto que no Centro obstétrico e na Recuperação pós-anestésica elas não têm acesso aos familiares".

(...) "É preciso a liberação do acompanhante e sensibilização de todos os médicos para o parto humanizado".

"Gostariamos que as pacientes da SEMI-INTENSIVA tivessem um acompanhamento mais organizado, para que elas não ficassem tão ansiosas e tanto tempo hospitalizadas, pois elas ficam bastante depressivas. embora estamos aqui para dar todo apoio a elas".

\subsubsection{Pontos positivos da instituição}

\subsubsection{Em relação à interação profissional}

Apesar da violencia no ambiente de trabalho, percebida e relatada por grande parte dos profissionais e visivel interação profissional em certos setores.

(...) "A equipe tem um entrosamento muito bom. ou melhor, ótimo". (Func. do Protocolo)

"Dentro do D.P não temos problemas, somos uma equipe unida. Sempre tentando colaborar com os colegas. Por isso somos taxados como panelinha". (Func. do DP) 
(...) "Em certos setores ainda existe coletividade e companheirismo" (Func. Ambulatório.)

"Temos entre nós simpatia, alegria e comunicação. Temos um bom relacionamento entre os funcionários do setor". (Secretárias da Diretoria)

(...) "Existe a receptividade do grupo de trabalho. Aqui há união para toda e qualquer tarefa". (Func. UTI)

"Os funcionários do D.P tratam bem a nós os funcionários". (Fun. Berçário)

\subsubsection{Em relação à infra-estrutura}

A infra-estrutura é inadequada, mas a administração da instituição tem otimizado da melhor maneira possível qualquer espaço para se desenvolver programas que contribuem com a humanização da assistência.

(...) "Um ponto positivo do $R H$ é que ele abre as 7:00hs e fecha as 20:00hs".

(...) "No setor está havendo mudanças, melhorias na estrutura fisica $e$ tecnológica para melhor atendimento e agilidade para o usuário". (Func. Recepção)

"Temos sala de amamentação, Banco de leite, Projeto Canguru (quando possivel), UTI adulto, neonatal e para baixo peso (até 1.200grs) 2 leitos". (Func. Berçário)

\subsubsection{Em relação à comunicação e integração entre os funcionários}

Logo que se deu início ao processo do diagnóstico de clima organizacional. observou-se melhora na comunicação e integração entre os funcionários, embora em alguns setores sempre tenha existido muita amizade e solidariedade entre eles. 
(...) "Em comparação há alguns anos atrás, acho que mudou muita coisa por aqui, porque antes aconteciam muitas coisas horrorosas, mas ainda falta muita coisa para melhorar".

(...) "Está havendo mais confraternizações entre os funcionários". (Enfermagem)

(...) "Existe muita empatia em nosso meio e boa vontade. Há muito amor com as tarefas (gostamos do que fazemos)". (Serviço Social)

(...) "Tem chefias (encarregadas) que procuram colaborar dentro do possivel". (AE)

(...) "A chefia atual que nos permite opinar e se for o melhor para equipe, mudar algumas coisas, ou seja, nos permite ter iniciativa". (Func. Recepção)

"Aqui tem bons tratamentos: os RNs tem um bom tratamento médico, pois quando apresenta um problema de saúde ou suspeita, ficam sobre vigilância dos médicos e enfermeiras. São feitos todos os exames e só tem alta quando é identificado tudo e muitas vezes os neonatologistas ainda os acompanham pelo Ambulatório; supervisores de enfermagem. berçário. Para mim são verdadeiras mães. Estão de Parabéns! " (Func. Berçário)

(...) "A diretoria veio pedir a nossa opinião e isto nunca aconteceu por aqui,espero que continuem" (Func. Aloj. Conj.)

\subsubsection{Em relação ao quadro de pessoal}

De quatro anos para cá. o HMI e seu Ambulatório contam com funcionários humanizados e de boa qualidade técnica.

(...) "O RH esta tentando dar um bom atendimento para os funcionários em geral. A direção do RHé boa". 
(...) "A diretoria é boa para os funcionários". (Func. Diretoria)

(...) "Boa qualidade dos médicos e enfermagem" (Func. CO)

"Este mês, dia par, está tudo ótimo, nós colegas nos entrosamos e as nossas enfermeiras são bem atenciosas" (Func. CO)

\subsubsection{Em relação ao treinamento e organização do trabalho}

A instituição sempre se preocupou em proporcionar treinamentos nos diversos temas referentes à Assistência Materno-neonatal.

(...) "Estes cursos de humanização que estão começando são pontos positivos". (AE)

"No Ambulatório se tem liberdade para trabalhar com qualidade. respeitando-se os limites de cada funcionário".

"Todos os projetos do hospital acontecem devido a dedicação dos profissionais". (Serviço Social)

(...) "Fazemos atendimento imediato a gestante com dor e tratamento e ensinando a prevenção" (Func. Ambulatório)

(...) "O começo da informatização do hospital, o programa para que ainda está em teste, mas acredito que amparando as arestas tudo ficará bem". (Func. Recepção)

\subsubsection{Em relação aos direitos dos usuários}

A administração não tem medido esforços para garantir ao cliente externo o atendimento de qualidade. 
"No hospital o atendimento é rápido. Muitos têm preocupação com o bem estar dos outros. Estamos sempre dispostos a atender as solicitações dentro do possivel". (Func. Diretoria)

"Temos respeito aos usuários Aqui temos orientação reforçada sobre o pré-natal, grupos de adolescentes, Planejamento familiar, Aleitamento Materno, Banco de leite e Curso de preparação do parto". (Func. Ambulatório, Serviço Social)

"Somos receptivos. Procuramos atender o paciente da melhor maneira possivel. Temos disposição em atender as solicitações feitas" (Func. Recepção Ambulatório, Secretárias da Diretoria.)

"As pacientes são bem acolhidas e ficam satisfeitas em conseguir ganhar o seu bebê nessa instituição". (Fun. Pré-parto)

\subsubsection{Sugestões de melhoria institucional por parte do cliente interno}

\subsubsection{Quanto à interação profissional}

Nas falas abaixo percebe-se a carência de interação e acolhimento entre as equipes.

(...) "Um ambiente de trabalho mais saudàvel, um ambiente de trabalho com menos sofrimento".(AE)

"Solicitar maior e melhor participação dos residentes". (Enfermagem)

"Companheirismo entre as pessoas que formam o quadro de funcionários. Treinamentos especificos, periódicos. cooperativismo entre as parte. chefia e subordinados. Melhoramento do ambiente de trabalho e pensamentos que dão suportes ao bom desempenho das atividades". (Sub-frota)

"Quando a funcionária chegar atrasada no trabalho, perguntar os motivos e observar quantas vezes está chegando atrasada e conversar sem punir imediatamente". (AE) 
"Estimular as auxiliares a fazer uma comemoração de aniversário, unir mais os colegas, perguntar quais os anseios de cada um com amor $e$ carinho com todos. Confraternizar mais a equipe". (AE)

\subsubsection{Quanto à infra-estrutura}

São pontos comuns entre o cliente interno: necessidade de investir em condições estruturais de sustentação da atenção humanizada ao parto e nascimento; apoio à estrutura do Comitê de Acolhimento e Humanização da Assistência Materno-Neonatal; políticas de Recursos Humanos que reduzam as inseguranças trabalhistas e técnicas; evitar distorções da concepção de "inversão do modelo".

"No caso dos funcionários terceirizados terem direito a refeiçōes, melhoria quanto aos seus ambientes de trabalho. Até no caso perguntarem pessoalmente para eles o que necessitam". (AE. Enfermagem, SAME, Segurança)

"Não temos um vestiário decente para gente mudar a roupa, tomar um banho". $\dot{E}$ necessário banheiro feminino e masculino com armários para todos os funcionários". (Enfermagem)

"Colocar balcões e cadeiras adequadas para o bom desempenho de nossas funçôes evitando doenças profissionais como: tendinite e problemas na coluna. As cadeiras são muito baixas". (Func. Recepção)

(...) "Fechar mais o vão do vidro da recepção, pois no inverno de madrugada o vento é muito grande". (Func. Recepção)

(...) "Macas com condições de uso e se possivel um transfer (não custa caro)". (Enfermagem)

(...) "Deve ser reavaliado a alimentaçâo do paciente no $P S$ ". (AE) 
“Adequação de móveis para o exercício da profissão desde recepção, enfermagem. Um balcão apropriado, aparelhos novos e em maior quantidade". (Enfermagem. SAME)

(...) "Queremos que volte o lanche das 16 horas". (AE, Recepção)

\subsubsection{Quanto à comunicação e integração dos serviços}

Percebe-se nas falas abaixo que o cliente interno gostaria de participar da administração da instituição e que há entraves na comunicação e integração entre funcionários e equipes.

(...) "Somos uma boa equipe de trabalho, nos acolhemos muito. Nunca fomos chamadas para discutir em reuniões, problemas sobre o serviço. dúvidas, erros, etc". (SAME, Enfermagem)

(...) "Melhoria da informação e comunicação entre os setores. A comunicação tem que ser mais ágil". (SAME, AE. Recepção, Sub-frota, Seguranças)

\subsubsection{Quanto ao quadro de pessoal}

A lógica de contratação do Estado e a ausência de concursos públicos para certas categorias é um dos entraves na humanização da assistência.

(...) "Um maior número de motoristas para remoção". (Sub-frota)

(...) "Gostaria que tivessem maior compreensão para os funcionários contratados e fazer remanejamento de funcionário que não se adapta em determinado setor". (AE)

"Acho que também o noturno deveria ter as normas, porque aqui neste hospital a diretoria só funciona de dia (diurno). A noite é completamente diferente. Tam.bem acho que a diretoria deveria sensibilizar e se colocar no lugar de quem fica 12 horas sem lanche da tarde" (AE) 


\subsubsection{Quanto ao treinamento e organização institucional}

Percebe-se nas falas abaixo sobretudo do pessoal noturno a vontade de serem capacitados. E a percepção do cliente interno quanto a necessidade daqueles com problemas de saúde de receber orientações sobre adequação satisfatória ao trabalho.

(...) "Queremos mais treinamento para os funcionários do noturno, reciclagem pessoal". (AE)

(...) "É necessário palestra para os funcionários com problemas de saúde na unidade". (Enfermagem)

(...) "Treinamento constante com os funcionários da parte administrativa". (Func. DP)

"Mais treinamento para os funcionários que ficam na recepção para não fazerem os mesmo erros". (SAME)

(...) "Esses cursos ou oficinas precisam ser mais freqüentes porque não temos dinheiro para pagá-los fora do hospital e isto ajuda demais nas nossas profissões". (AE, Enfermagem)

"Verificar as queixas e cobranças dos médicos que muitas vezes são sem justificativas". (Enfermagem)

(...) "Fazer reunião mensal, para passar as últimas mudanças e soluções possiveis em todos os setores". (AE)

\subsubsection{Quanto aos direitos dos usuários}

Embora o cliente interno tenha parte dos seus direitos não contemplados ele reconhece a não legitimação de muitos direitos dos usuários.

(...) "Maior informação para a gestante durante o pré-natal. preparo psicologico. transmitir segurança a gestante durante o pré-natal. Que o médico permanecesse no PS, em forma de rodizio". (AE) 
(...) "A enfermagem precisa ter mais acolhimento e interação com a recepção. Dar maior atenção aos funcionários noturnos $e$ as adolescentes em geral, mesmo as que não fazem Pré-Natal aqui". (Func. Recepção)

"Aumentar a carga horária de visita de paciente que está reduzida por falta de funcionário". (Enfermagem)

\subsection{Resultados das entrevistas}

\subsubsection{Principais ancoragens}

Com fundamento nas 67 entrevistas em profundidade com o cliente interno, encontramos as seguintes ancoragens:

(...) Essa entidade maternidade sensibiliza a todos nós. A obstetricia é uma especialidade gratificante, de muita alegria, é uma especialidade de muito conforto, de

muito calor humano. É uma área extremamente humana chega bem perto da intimidade da mulher. Ajudar as pessoas é muito gratificante. É lindo o parto normal. O nascimento é o fenômeno de maior importância do universo. O parto humanizado é maravilhoso.

\section{Discurso dos profissionais que optaram pela profissão que exercem por outros interesses exceto por vocação}

Hoje em dia, a pessoa que não tiver uma profissão está dificil. Obstetricia cansa demais. e precisa acordar nas madrugadas. Hoje em dia só dá para fazer obstetricia nos plantões. Para sobreviver precisa ter pelo menos um emprego público.

\section{Por que escolheu este Hospital para trabalhar?}

La vida a gente nem sempre escolhe o que quer. No serviço puiblico você não escolhe. você é escolhido. As vezes você escolhe o que quer e não escolhe bem : às vezes você não tem a opção de escolher e acaba em lugares onde você tem experiências 
gratificantes . Hoje em dia para quem está se formando está muito mais dificil arranjar emprego.

\section{Está satisfeito com o que vem desempenhando aqui?}

Satisfeita a gente nunca fica. O ser humano é um eterno insatisfeito. A insatisfação éa marca do progresso. A busca por mudanças é constante. Sempre é tempo de adquirir mais conhecimentos. Sempre dá para fazer mais do que está se fazendo. O desempenho sempre deve ser melhorado. O trabalho exige constante aprendizado. Tem muitas pessoas que as vezes gosta de uma determinada especialidade, mas as vezes não gosta do setor aonde está trabalhando. O contato com um grande número de pessoas é gratificante. Se você trabalha num bom ambiente tudo vem a satisfazer. Não é tão dificil agradar um usuário dentro do hospital. Toda pessoa quando faz o que gosta, ela dá o melhor de si. Faz tudo para fazer o melhor. Profissionais de saúde procuram fazer o melhor para a paciente. Em pleno século XXI a mulher sentir dor na hora do parto é ridiculo. A gente fica satisfeita quando vê as pessoas elogiando o nosso hospital. A humanização muda a relação entre as pessoas. Quando a ficha cai, a humanização avança. Quando deixam o funcionário falar, as coisas avançam. Em vez

de apontar os erros tem que apontar as qualidades. É suh-humano você ter três auxiliares de enfermagem para cuidar de quarenta mães e de quarenta bebês. O médico não ganha um salário para poder se dedicar em tempo integral. Hoje em dia quem não tem dois empregos passa fome.

\section{O que você entende por Humanização da Assistência Materno-Neonatal}

Humanizar é não atrapalhar o nascimento. É o nascer bem e dignamente. É o que é melhor para mãe e o neném. É tirar a dor da paciente. Não dá para descolar a mãe da criança. do recém-nascido. Qualquer coisa que você transmita para mãe está indiretamente transmitindo para o filho. Tudo que ela receber também ela estará transferindo para a criança. O parto natural. o parto normal. vai ser mais natural ainda com esse trabalho de humanização. Humanização é você estar dando um apoio psicológico para mãe. Orientando para ela amamentar, da importância da 
amamentação, da importância do vinculo maternal. O parto humanizado tem que ser uma coisa mais carinhosa, mais atenciosa porque ela está numa situação fragilizada,

não doente, porém fragilizada. Não precisa ter curso de parto para se ter parto humanizado. Todo mundo gosta de carinho. Garantir o conforto, privacidade, alimentação, oferecer líquidos, a possibilidade da gestante caminhar, escolher a posição para seu parto. Preparar a gestante para o inesperado, cesárea por exemplo. garantindo a qualidade do atendimento. Favorecer a presença de um acompanhante no pré-natal e parto. Possibilitar a presença do pai. A gente tem que concentrar o nosso esforço total na parte de atendimento, conforto e calor humano em cima da entidade mãe. É a forma natural de nascer e ser recebido pelo mundo. Humanização é a pessoa humana. O entendimento entre o ser humano sadio, saudável, não é fácil. Humanização do parto é um parto humano, é um parto com dedicação. Se as mulheres não forem preparadas. não dá para fazer parto humanizado. Elas falam que querem parto normal da boca para fora. Na hora que estão na cama gemendo de dor, todas querem cesárea. Fica dificil fazer parto humanizado se elas chegam dizendo que não podem ter parto normal. A realidade é uma for do trabalho de parto e no trabalho de parto a realidade é outra. totalmente diferente. Agüentar marido de paciente bêbado não é fácil. As mulheres despreparadas gritam muito no parto.

\section{Quanto aos itens de humanização nesta instituição}

É o contato é o saber do funcionário, é o perguntar, é a troca que a gente tem com alguns funcionários sobre os problemas da Maternidade. Por ser uma Maternidade pública. esta é muito boa. Às vezes tem pessoas de fora que tem convênio e deixam o convênio e vem ser atendido aqui. Às vezes elas ficam bravas: não, mas eu quero ficar. me deixe ficar porque eu gosto daqui. É melhor estar aqui sendo bem tratada do que estar em um hotel cinco estrelas sendo desprezada.

\section{Quanto aos itens de desumanização nesta instituição}

A realidade do nosso pais é muito contraditoria. No hospital público podemos encontrar as diferentes classes de pessoa. O médico às vezes acha que sabe tudo. 
Pessoas que não vestem a camisa da instituição, principalmente os médicos que acham que são deuses. O governo precisa liberar verba porque hoje em dia a situação não está fácil

A estrutura física do hospital atrapalha o processo de humanização da assistência?

Para haver humanização a gente precisa de sensibilidade não de estrutura fisica. Aqui é igual coração de mãe, sempre cabe mais um. A gente pode tratar bem as pessoas, independente do tamanho do local. Hospital pequeno demais atrapalha a comunicação.

Todo mundo falando ao mesmo tempo acaba um atrapalhando o serviço do outro.

\section{Qual o profissional que oferece mais resistência no processo de humanização?}

O parto humanizado é uma coisa mais demorada. A gente é treinada parar ser mais resolutivo. O médico é sempre a parte aonde vai estourar as coisas. Os médicos são muito estressados. Não tem cabimento o profissional atrapalhar a humanização. $O$ médico quando sensibilizado é o maior colaborador.

\section{Qual o profissional que mais colabora no processo de humanização?}

As entermeiras. elas até são humanizadas, só que é tanta burocracia no papel que elas se perdem no papel e não tem tempo para a paciente. Ás vezes você vê enfermeiro que trata bem. tem enfermeiro que não trata bem. tem médico que é super bonzinho, tem outros que não são. Os médicos colaboram muito também. mas a enfermagem é que

está mais tempo com a paciente. É em ultimo caso que as mulheres chamam o médico. a primeira palavra que vem na boca sempre é a enfermeira, chama a enfermeira. $O$ médico vem. passa a visita e vai embora e há desencontro médico, porque o plantonista vem. amanhã vem outro, depois vem outro depois de amanhã vem outro. Começa do Pronto Socorro. aqui a mãe é hem recebida à gente orienta. a gente a recebe bem. As vezes nós temos mães chorosas. entâo você procura humanizar ela aqui. a gente tentar passar uma coisa boa para elas aqui. Dai a pessoa chega aqui esta deprimida. chorosa e quando ela encontra você e você conversa com ela. deixa ela a vontade ela já 
melhora. Os auxiliares de enfermagem começam o bom atendimento, a gente que recebe elas, deixa elas a vontade, conversam, ouvem o que elas tem a declarar. É um serviço que depende muito um do outro, porque não adianta você ser bem atendida aqui e ser mal atendida lá em cima. A assistente social se não fosse tão complicada poderia colaborar mais ainda na humanização. Todo neonatologista compreende o bebê, sabe respeitar a identidade do feto. O auxiliar de enfermagem é o profissional mais acolhedor. Os auxiliares de enfermagem a maioria são humanos. $O$ auxiliar de enfermagem costuma ter mais paciência. Somente a motivação faz com que projetos sejam implantados com sucesso. E uma coisa de vestir a camisa mesmo, ou você veste a camisa ou você não veste a camisa. Dá para contar nos dedos os profissionais que colaboram com o parto humanizado.

\section{O atendimento ao pré-natal influência o processo de humanização da assistência?}

Fazer um bom pré-natal é fundamental. É o inicio de toda a humanização. A primeira impressão é a que fica. Quando você vai fazer uma coisa que você não conhece, você vai mais insegura. com medo. O pré-natal é importantíssimo. Quando ela começa ser preparada no pré-natal, ela fica mais sem medo. ela não vem tão armada para o hospital. O pré-natal é o início. a partir de lá preparam ela para nove meses depois ela vir ganhar o bebê. O pré-natal na instituição pública é melhor do que os de convênios que de 5 em 5 minutos tem que se atender uma paciente. O pré-natal com qualidade trás muitos resultados. Um pré-natal humanizado faz parte do ciclo de nascimento.

\section{A história de vida dos profissionais influencia o processo de humanização da assistência?}

Nossas experiências e nossas emoções estão sempre presentes em todas as nossas ações. Cada um de nós trazemos traços próprios desde a infância. Quando você é criado com amor. no mínimo devolverá amor. Nós somos o que construimos na nossa historia de vida. Alguém com experiência de dar e receber afeto certamente estará mais preparada para a experiência da humanização. Aquele que não recebeu afeto nem saberá do que você está falando. Cada um tem uma forma de encarar a vida. Porque tem médicos que 
fazem a sua profissão por amor, tem outros que já fazem até mesmo por interesse financeiro. Estes médicos muito novinhos não têm humanização. Se a pessoa não está interessada em ajudar primeiro a pessoa e depois o pagamento dela. eu acho que ela não tem a minima condição de fazer um parto humanizado. A vida realmente não é nada de flores e perfumes. Atender até 80 fichas no plantão, assim não dá para fazer humanização. Toda história de vida dos atores envolvidos nas ações de saúde influenciam, modificam e interferem no trabalho desenvolvido. Tem que ter um jogo de

cintura, para estar entrando na porta e deixando a sua vida particular lá fora. $O$ profissional que vem com problema de casa, ele desabafa com certeza na mãezinha. Casa é casa, serviço é serviço e trabalho é trabalho. Aqui você vem para trabalhar e tem que procurar tudo de melhor para você fazer e não misturar as estações. Cada cabeça pensa

de um jeito. Cada um pode ser um profissional que soma ou diminui para a humanização. Existem aqueles que já tem no seu âmago predisposição para ajudar as pessoas. Nós seres humanos, nós estamos aqui para ajudar uns aos outros. Nós todos dependemos um do outro. Aqui ninguém é melhor do que ninguém. Quando buscamos melhorar as relações usuário/profissional, profissional/profissional, chefias profissionais, estamos trabalhando com relações entre pessoas.

\section{A história de vida das pacientes influencia o processo de humanização da assistência?}

A obstetricia é uma caixa de surpresas. Aquele que não sabe dar afeto tem maiores dificuldades de entender a necessidade do outro. Aquele que nunca recebeu afeto não saberá reconhecer o tratamento mais humano proposto pela humanização no atendimento. As mulheres daqui da região são muito sofridas. Conhecendo a história de vida da paciente é muito mais fácil para gente trabalhar na humanização. Se a paciente tem uma história de vida complicada, ela acaba dando mais trabalho. Se ela já teve uma complicação na gestação anterior, então ela já vem com aquilo, marcado. Se é uma gestante que o pai põe para fora de casa. ela vai chegar aqui se sentindo meio coagida. Sé é uma gestante que sofre violência da familia, desprezo, preconceito. ela vai se colocar na defensiva. Mulheres que sofreram violência não tem parto normal de modo algum. Nem pensar em fazer parto normal em adolescente que não quer a 
gravidez. E o trabalho da gente é estar prestando uma qualidade de serviço a quem realmente está precisando. O ser humano é muito versátil e sensivel. Só é compreensivo quem consegue enxergar o intimo delas. Nem sempre é assim, nem todo mundo aceita as coisas. Tem marido de paciente que é muito ignorante. Tem marido que não sabe que o exame de toque faz parte de todo procedimento e acha que vai fazer sacanagem com a mulher dele. O ser humano é muito de estar querendo que você entenda o problema dele e sofra junto com ele. A cultura da cesárea está muito sedimentada entre as mulheres. Elas já chegam aqui pedindo cesárea. As pacientes se comportam geralmente bem, quem sempre desestrutura o trabalho é o acompanhante. O ponto de

vista religioso é muito importante. A religião resgata a auto-estima, traz novos horizontes para esta mulher. Quem não tem um passado, quem não tem um problema!

\subsubsection{Discurso do sujeito coletivo}

Com fundamento no material extraído nas entrevistas em profundidade com o cliente interno e de acordo com a metodologia de LEFÈVRE e LEFÈVRE 2000, chegou-se aos seguintes discursos: 


\section{DISCURSO DO SUJEITO COLETIVO}

\section{Por que escolheu este hospital para trabalhar?}

\begin{tabular}{|c|c|c|}
\hline $\begin{array}{c}\text { IDEIA } \\
\text { CENTRALA }\end{array}$ & $\begin{array}{l}\text { Médicos (Obstetras, Residentes, Neonatologistas, } \\
\text { Anestesiologistas, UTI Materno e Neonatal) }\end{array}$ & Direçåo do HMI e Ambulatório \\
\hline $\begin{array}{c}\text { Foi convidado } \\
\text { pela } \\
\text { Administração } \\
\text { do Hospital }\end{array}$ & $\begin{array}{l}\text { No inicio não foi a minha escolha. Em um dos governos uma colega foi } \\
\text { convidada para assumir o hospital no aspecto administrativo e ela me pediu } \\
\text { uma colaboração, se eu poderia ajudá-la e quem sabe fazer este hospital a } \\
\text { maternidade que é hoje. Eu vim para cá com outros amigos, e foi feito um } \\
\text { concurso público, eu prestei o concurso, entrei e estou aqui desde a época que } \\
\text { abriu o hospital até nos dias de hoje. Eu fui indicado no começo. O hospital } \\
\text { começou com indicaçðes de outras pessoas. Eu fui convidado para trabalhar } \\
\text { aqui e me sinto muito honrado desde então. Eu trabalhava no hospital da rede } \\
\text { privada, este hospital teve uma reestruturaça e eu fui convidado para } \\
\text { trabalhar aqui. Na época eu conhecia a chefe da residência e ela conhecendo o } \\
\text { meu modo de trabalho disse que precisava de uma pessoa como eu aqui neste } \\
\text { hospital. Então foi através da residência que eu comecei aqui no hospital. Eu } \\
\text { me identifico com as pessoas que trabalham aqui e eu fui convidado e prestei o } \\
\text { concurso público, passei e estou aqui. } \\
\text { Sujeitos: (O1, O2, O4, O3, Al) }\end{array}$ & $\begin{array}{l}\text { Na vida a gente nem sempre escolhe o que quer. As vezes você escolhe o que quer } \\
\text { e não escolhe bem e as vezes você não tem a opção de escolher e acaba em lugares } \\
\text { onde você têm experiências gratificantes. No meu caso, eu comecei como médico } \\
\text { concursado no antigo INAMPS no ambulatório que hoje é o ambulatório da } \\
\text { Maternidade Interlagos. Desde } 1983 \text { que eu estou ali atendendo como obstetra } \\
\text { ginecologista e em } 1999 \text { surgiu a oportunidade. A Maternidade estava querendo } \\
\text { implantar o seu ambulatório próprio de obstetricia e como eu tinha uma experiência } \\
\text { razoável no setor, eu fui convidado pela Diretora da Maternidade naquela época, } \\
\text { para vir implantar e criar o serviço de ambulatório aqui nesta Maternidade e a coisa } \\
\text { foi evoluindo, o trabalho frutificou no ambulatório e eu tive a oportunidade de } \\
\text { depois com a saida da diretora anterior, de assumir a diretoria da Maternidade } \\
\text { Interlagos. Então, eu cheguei aqui convidado para participar da administração e } \\
\text { ajudar na reconstrução daqui. Surgiu a oportunidade, e eu aceitei. } \\
\text { Sujeitos: (DG, DC, DRH) }\end{array}$ \\
\hline
\end{tabular}

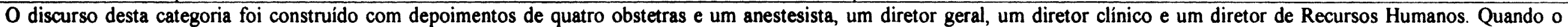

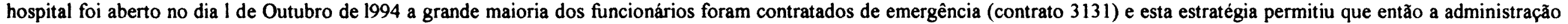
escolhesse a dedo os seus colaboradores. Posteriormente houveram os concursos e mais de $50 \%$ desses profissionais tornaram efetivos. 


\section{DISCURSO DO SUJEITO COLETIVO}

\section{Por que escolheu este hospital para trabalhar?}

\begin{tabular}{|c|c|c|c|}
\hline $\begin{array}{c}\text { IDEIA } \\
\text { CENTRALA }\end{array}$ & $\begin{array}{l}\text { Profissionais da área } \\
\text { Administrativa }\end{array}$ & Outros profissionais da área Assistencial & $\begin{array}{l}\text { Líderes Setoriais } \\
\text { de Acolhimento }\end{array}$ \\
\hline $\begin{array}{c}\text { Foi convidado } \\
\text { pela } \\
\text { Administração } \\
\text { do Hospital }\end{array}$ & $\begin{array}{l}\text { Na inauguração do Hospital } \\
\text { Maternidade Interlagos, eu fui } \\
\text { convidada para vir trabalhar } \\
\text { aqui, para abrir o Departamento } \\
\text { Pessoal que não tinha } \\
\text { Departamento Pessoal aberto } \\
\text { aqui. Então fui convidada a vir } \\
\text { para cá, e como moro perto } \\
\text { aqui, tudo encaixou. Então aí } \\
\text { foi que eu iniciei aqui no } \\
\text { hospital. Sujeitos: (OA3) }\end{array}$ & $\begin{array}{l}\text { Eu trabalhava no Servidor Municipal e um dos Diretores do HMI, trabalhava no CEPACO, onde eu } \\
\text { trabalhava tinha uma farmacêutica que era amiga do diretor do HMI e ela trabalhava no CEPACO e no } \\
\text { Servidor e o diretor do HMI estava procurando uma pessoa para trabalhar aqui, pois ele estava montando } \\
\text { um serviço de atendimento as parturientes e queria montar uma equipe de obstetrizes e enfermeiras } \\
\text { obstetras naquela época e ele queria que o atendimento fosse feito pela enfermagem e não pelo médico. } \\
\text { Quando o Diretor daqui soube que eu estava no trabalho de humanização, ele me convidou para eu vir } \\
\text { ajudar a implantar a Humanizaçăo da Assistência aqui.. E eu fui chamada para fazer parte da equipe. Eu } \\
\text { moro na zona Norte, aqui é extremo Sul, é meio longe. O salário do serviço público não é muito bom. Ele } \\
\text { me convidou para trabalhar aqui, eu aceitei, eu não tinha muita experiência, eu trabalhava no Municipal eu } \\
\text { não era enfermeira, eu era ainda auxiliar, mesmo formada eu trabalhava como auxiliar. Na verdade eu não } \\
\text { escolhi, Havia um cargo disponivel e eu aceitei. Ele me convidou, eu aceitei e estou aqui desde 1998. } \\
\text { Sujeitos: (E2, E1, P2, F2) }\end{array}$ & \\
\hline
\end{tabular}

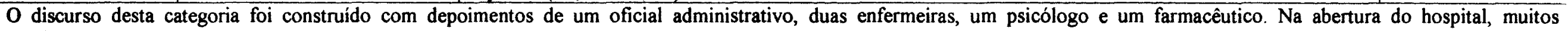
funcionários contratados de emergência tiveram seus contratos renovados por pelo menos uma vez caso a administração julgasse necessário

\begin{tabular}{|c|c|c|c|}
\hline $\begin{array}{c}\text { IDEIA } \\
\text { CENTRALB }\end{array}$ & $\begin{array}{c}\text { Médicos (Obstetras, Residentes, Neonatologistas, Anestesiologistas, UTI } \\
\text { Materno e Neonatal) }\end{array}$ & $\begin{array}{l}\text { Outros Profissionais } \\
\text { da Área Assistencial }\end{array}$ & $\begin{array}{l}\text { Profissionais da Área } \\
\text { Assistencial }\end{array}$ \\
\hline $\begin{array}{c}\text { Não } \\
\text { escolheu, } \\
\text { passou no } \\
\text { concurso do } \\
\text { estado }\end{array}$ & $\begin{array}{l}\text { Esse hospital aqui, faz parte da residência do Pérola Byghton. Eu passei no SUS e eu gostava do } \\
\text { Pérola, por causa da parte de gineco e a obstetrícia é aqui no Interlagos. A gente faz a parte de } \\
\text { ginecologia no Pérola Byghton e aqui se localiza a área de obstetricia. O volume de pacientes aqui é } \\
\text { muito grande. Lá no Pérola chega a } 3.000 \text { consultas/dia. O importante do Pérola, é que lá tem todas } \\
\text { as sub-especialidades dentro da ginecologia. E uma que me interessa é fazer mastologia. Os } \\
\text { Residentes ficaram sabendo que abriram o Hospital e que tinha vaga aqui, me chamaram, depois de } \\
\text { um tempo teve o primeiro concurso, eu prestei, passei e eu ainda estava no final da Residência } \\
\text { quando eu passei. Aqui é um hospital bem renomado e eu sabia que aqui eu ia estar preparada depois } \\
\text { para atender bem as pacientes e para o mercado de trabalho também. Sujeitos: (RD, RA, RB, O5) }\end{array}$ & $\begin{array}{l}\text { Eu fiz concurso e fui } \\
\text { chamada para cá. } \\
\text { Sujeitos: (TL) }\end{array}$ & $\begin{array}{l}\text { Não foi opção. Eu entrei aqui } \\
\text { porque eu prestei concurso, a } \\
\text { opção era apoio ao usuário. Logo } \\
\text { de inicio, eu não tinha muita } \\
\text { experiência aqui no hospital e na } \\
\text { primeira e segunda semana eu já } \\
\text { consegui me identificar um pouco } \\
\text { no serviço. É a minha cara para } \\
\text { dizer a verdade. Sujeitos: (OAS) }\end{array}$ \\
\hline
\end{tabular}


DISCURSO DO SUJEITO COLEIIVO

Por que escolheu este hospital para trabalhar?

\begin{tabular}{|c|c|c|c|}
\hline $\begin{array}{c}\text { IDEIA } \\
\text { CENTRALC }\end{array}$ & Profissionais da área Administrativa & $\begin{array}{c}\text { Outros } \\
\text { profissionais da } \\
\text { drea Assistencial }\end{array}$ & $\begin{array}{l}\text { Lideres Setoriais } \\
\text { de Acolhimento }\end{array}$ \\
\hline $\begin{array}{l}\text { Foi } \\
\text { encaminhado } \\
\text { pela empresa } \\
\text { onde trabalhava }\end{array}$ & $\begin{array}{l}\text { Foi uma coincidência. Eu vim trazer minha sobrinha aqui para fazer exame, ai comecei a conversar com o rapaz } \\
\text { daqui. Depois, eu fui encaminhado pela empresa para este hospital. Năo escolhi, fui encaminhado pela empresa. } \\
\text { Entăo não tive nenhum problema. Eu conheci esse hospital pela empresa. A empresa conseguiu contrato aqui, a } \\
\text { empresa que tem contrato aqui. Adoro trabalhar aqui. Se um dia eu sair daqui eu vou sentir muita falta, pelo fato } \\
\text { de estar ajudando as mãezinhas, paizinhos. Sujeitos: (S2, S1, S4, AL2) }\end{array}$ & & \\
\hline
\end{tabular}

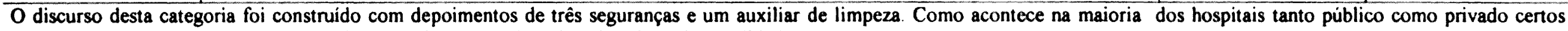
setores como Segurança, Nutriçăo, Serviços Gerais săo terceirizados visando maior qualidade

\begin{tabular}{|c|c|c|}
\hline $\begin{array}{c}\text { IDELA } \\
\text { CENTRAL D }\end{array}$ & Direçåo do HMI e do Ambulatório & Outros profissionais da área Assistencial \\
\hline $\begin{array}{c}\text { Identificação } \\
\text { com os } \\
\text { programas } \\
\text { de } \\
\text { Humanizacã } \\
\text { o do Hospital }\end{array}$ & $\begin{array}{l}\text { Eu gosto, por ter objetivos do Amigo da Criança, a implantaça do parto humanizado Então eu acabei } \\
\text { optando por trabalhar em hospitais que fizessem o parto humanizado. Este hospital, ele visa o parto } \\
\text { humanizado e ele é um Hospital Amigo da Criança, que tem os objetivos que enquadram com aquilo } \\
\text { que eu penso. Trabalhei no Hospital Estadual da Vila Alpina, que também é do Governo Estadual e ele } \\
\text { também faz parto humanizado. } \\
\text { Ao terminar a faculdade passei por um estágio de dois anos em uma Clínica Social de Psicologia que } \\
\text { atendia uma população mais carente. Surgiu neste periodo o interesse em realizar meu trabalho em uma } \\
\text { unidade de saúde pública. Após realizaça de concurso público fui contratada para exercer esta função } \\
\text { no Posto de Atendimento Médico Cidade Dutra. O contrato com o Hospital ocorreu a partir de } 2000 \\
\text { com a incorporação do PAM Cidade Dutra, passei a ter um maior contato com o HMI. A escolha se deu } \\
\text { em função dos programas oferecidos pelo Hospital, a partir da Iniciativa Hospital Amigo da Criança } \\
\text { comecei a participar mais ativamente das atividades de humanização da unidade. Então, eu vim fazer } \\
\text { uma entrevista e na época que eu vim o Hospital estava pleiteando o titulo "Amigo da Criança". Eu } \\
\text { passei na entrevista, passei na prova e vim trabalhar no ambulatório. Modificamos todo o ambulatorio } \\
\text { da Maternidade Interlagos. Então, para mim trabalhar aqui na Maternidade Interlagos é um grande } \\
\text { desafio, porque é uma constante mudança de tentar melhorar sempre o serviço público. Eu tenho aqui o } \\
\text { Hospital Maternidade Interlagos como um desafio para minha pessoa. Sujeitos: (N1, N2, N3, DA, E) }\end{array}$ & $\begin{array}{l}\text { Sempre eu soube que aqui era uma Maternidade que tinha } \\
\text { tudo para dar certo em relação a humanização, como eu fui } \\
\text { sempre muito voltada para esta questão da humanizaçăo, } \\
\text { como eu sou integrante do Colegiado do Ministério da } \\
\text { Saúde, com relaçăo ao prêmio Galba de Araújo, isso foi } \\
\text { realmente uma coisa muito importante para mim, já fui } \\
\text { também do estado, então quando a Diretora daqui soube que } \\
\text { eu estava nesse trabalho, ela me convidou para vir } \\
\text { exatamente ajudar a implantar a Humanização da } \\
\text { Assistência aqui. Então è isso, nós estamos tentando a cada } \\
\text { dia melhorar as condiçסes para que a Humanização seja } \\
\text { realmente efetivada em todos os meandros que tem que ser } \\
\text { efetivados, entåo é neste sentido que a gente esta } \\
\text { construindo, se organizando cada vez mais para que isso } \\
\text { ocorra. Fiz o concurso em } 1997 \text { e já sabia que era um } \\
\text { Hospital somente de maternidade e que eu estava } \\
\text { completamente inserida. } \\
\text { Sujeitos: (E2, E3) }\end{array}$ \\
\hline
\end{tabular}

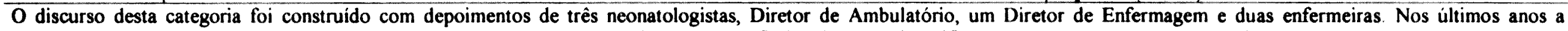
instituiçăo tem se voltado para os Programas de Humanização da Assistência e certos profissionais que se identificam com os mesmos tem procurado trabalhar no HMI 


\section{DISCURSO DO SUJEITO COIETIVO}

\section{Por que escolheu este hospital para trabalhar?}

\begin{tabular}{|c|c|c|c|}
\hline $\begin{array}{c}\text { IDEIA } \\
\text { CENTRALE }\end{array}$ & $\begin{array}{c}\text { Profissionais da área } \\
\text { Administrativa }\end{array}$ & Outros profissionais da área Assistencial & $\begin{array}{l}\text { Lideres Setoriais } \\
\text { de Acolhimento }\end{array}$ \\
\hline $\begin{array}{l}\text { Mora perto do } \\
\text { Hospital }\end{array}$ & $\begin{array}{l}\text { Porque é um lugar próximo de onde eu } \\
\text { moro. Então já me facilitaria bastante e, } \\
\text { eu prestei o concurso porque, eu } \\
\text { realmente não tinha nenhuma outra } \\
\text { opção e fui colocada aqui no RH porque } \\
\text { antes eu já trabalhava mexendo com o } \\
\text { pessoal, e era uma firma particular, mas } \\
\text { eu mexia muito com papéis, eu sempre } \\
\text { gostei disso. Então fui colocada aqui e } \\
\text { me dei muito bem. Era o mais próximo } \\
\text { da minha casa e eu sempre gostei do } \\
\text { HMI, porque eu já tive uma filha aqui e, } \\
\text { achei muito dez a limpeza do local. Eu } \\
\text { estava desempregada. Ai como não tinha } \\
\text { outra opção, eu fiquei neste setor } \\
\text { mesmo. } \\
\text { Sujeitos: (OA2, AL3, AL1) }\end{array}$ & $\begin{array}{l}\text { Eu não escolhi, eu moro aqui perto. Eu sou concursada, eu prestei concurso, passei e vim } \\
\text { trabalhar aqui. Na verdade este Hospital ele existe há muito tempo, e eu moro aqui na } \\
\text { região. Então eu sempre imaginei: "Ai meu Deus, puxa vida como que eu queria, se um } \\
\text { dia eu fizer uma faculdade ou fazer alguma coisa relacionado a saúde, eu queria trabalhar } \\
\text { aqui". É uma coisa de carinho mesmo, é uma coisa que eu passava na avenida e via a } \\
\text { Maternidade, porque lá da avenida dá para ver só a ponta do prédio e eu idealizava aqui, } \\
\text { porque eu achava que trabalhar aqui seria um lugar legal para trabalhar pelo fato de ser } \\
\text { perto de casa e você está sempre em contato com as pessoas próximas de você, da } \\
\text { comunidade. Eu acho que foi isso, eu sempre quis mesmo trabalhar por este lado. Este } \\
\text { hospital foi inaugurado em } 1994 \text { eu estava fazendo curso e eu fiquei animada, eu pensei: } \\
\text { "eu terminando o curso eu vou lá procurar emprego". Então foi isso, eu terminei em } \\
\text { dezembro, vim aqui em meados de maio, junho eu já vim procurar emprego. Ai fiz uma } \\
\text { entrevista e eu dou graças a Maternidade, porque hoje em dia quem está se formando está } \\
\text { muito mais dificil de arranjar emprego e este Hospital ele abriu os braços para o pessoal } \\
\text { recém formado. Então, a gente não teve tanta dificuldade de ter o primeiro emprego e essa } \\
\text { Maternidade deu essa oportunidade. A gente entrou fazendo uma entrevista. } \\
\text { Sujeitos: (E6, AE3) }\end{array}$ & \\
\hline
\end{tabular}

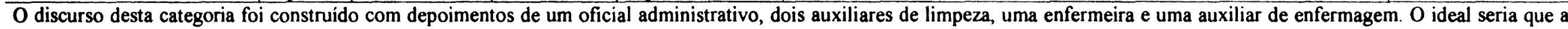
maioria dos funcionários morassem perto dos seus trabalhos. Isto também seria um fator de humanização. 


\section{DISC CURSO DO SUJEITO COIETIVO}

\section{Por que escolheu este hospital para trabalhar?}

\begin{tabular}{|c|c|c|c|}
\hline $\begin{array}{c}\text { IDEIA } \\
\text { CENTRALF }\end{array}$ & Profissionais da d́rea Administrativa & Outros profissionais da área Assistencial & $\begin{array}{l}\text { Líderes Setoriais } \\
\text { de Acolhimento }\end{array}$ \\
\hline $\begin{array}{c}\text { Por } \\
\text { indicação de } \\
\text { amigos }\end{array}$ & $\begin{array}{l}\text { Eu tinha uma vizinha que trabalhava aqui, e eu estava } \\
\text { desempregada, ela disse que tinha uma vaga e eu vim meio } \\
\text { desinteressada, ai fiz o teste, a chefe perguntou se eu poderia } \\
\text { começar no mesmo dia. Eu comecei em um ritmo acelerado, } \\
\text { fiquei uma semana trabalhando doze horas para conhecer os } \\
\text { setores. Porque o arquivo, ele era vinculado a mais alguns } \\
\text { setores, recepcão, central de guardas, portarias. Cada dia a } \\
\text { gente ficava em um setor, tinha atendimento de telefone, a } \\
\text { gente elaborava o censo, era tudo vinculado em um único } \\
\text { setor, ai depois foi desvinculando. Agora está só o arquivo e } \\
\text { eu continuo no arquivo. Então, eu escolhi na influencia de } \\
\text { uma vizinha minha, que trabalhava aqui, e ela falou que eu } \\
\text { tinha uma grande oportunidade de crescer aqui. Então, foi } \\
\text { através dela que eu consegui entrar, porque a gente não era } \\
\text { concursado na época, era só por contrato e ela me colocou } \\
\text { aqui, e eu dei continuidade. } \\
\text { Sujeitos: (OAl, OA4) }\end{array}$ & $\begin{array}{l}\text { É até meio engracado, porque, eu não sou daqui. Quando eu vim para cá, eu vim } \\
\text { procurar emprego. Esse hospital quando estava em formaça, tinha um grupo de } \\
\text { enfermeiros em Santos que me chamaram para vir para cá, estava montando o } \\
\text { serviço de enfermagem. O pessoal foi embora, não se adaptou ao hospital. Eles } \\
\text { disseram que aqui era maternidade, quando eu fiz estágio na minha faculdade, } \\
\text { uma área que eu detestei foi maternidade, eu falei assim: eu não quero trabalhar } \\
\text { em maternidade. Ai eu vim para Såo Paulo e tinha essa vaga no hospital aqui, ai } \\
\text { eu entrei, e foi um desafio para mim, porque na época eu não gostava, e depois } \\
\text { eu fui gostando de maternidade, tanto é que eu fiz pós-graduaçao em obstetricia. } \\
\text { Então, eu tinha pessoas amigas que trabalhavam comigo em outro hospital e eu } \\
\text { morava na época em outra região, eu tive que me transferi para Zona Sul. Eu } \\
\text { gostava de crianças, mas não de maternidade, mas acabei me adaptando e } \\
\text { gostando. Eu gosto de estar atendendo esse lado mais carente da população, eu vi } \\
\text { que tinha tudo haver comigo. Eu acho muito importante dar um atendimento } \\
\text { mais especifico a essas pessoas. Eu sempre tive curiosidade de saber, como é } \\
\text { trabalhar em hospital público, na área pública. } \\
\text { Sujeitos: (E7, E4, E5, F1) }\end{array}$ & \\
\hline
\end{tabular}

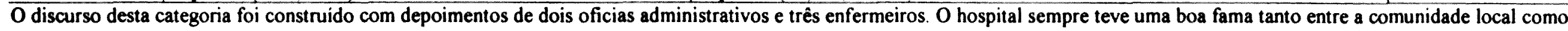
entre a acadêmica e muitos profissionais escolheu a instituição por este motivo 


\section{DISCURSO DO SUJEITO (CI.ETIVO)}

\section{Por que escolheu este hospital para trabalhar?}

\begin{tabular}{|c|c|c|}
\hline $\begin{array}{c}\text { IDEIA } \\
\text { CENTRALG }\end{array}$ & $\begin{array}{l}\text { Profissionais da área } \\
\text { Administrativa }\end{array}$ & Outros profissionais da área Assistencial \\
\hline $\begin{array}{c}\text { Sempre } \\
\text { sonhou } \\
\text { trabalhar em } \\
\text { Maternidade }\end{array}$ & & $\begin{array}{l}\text { Eu tinha um sonho de ingressar na maternidade, trabalhar na maternidade. Eu era atendente. Comecei como } \\
\text { atendente em um posto de saúde perto da minha casa, depois eu fiz o curso de auxiliar de enfermagem que fo } \\
\text { em } 94 \text {, ai eu me demiti. Ingressei aqui como auxiliar contratada, depois eu efetivei, e continuo aqui, porque eu } \\
\text { gosto de maternidade, eu gosto de trabalhar na maternidade. Este Hospital já estava na minha trilha faz muito } \\
\text { tempo. Desde a época que estudava eu tinha colegas que trabalhavam aqui, eu tinha muita vontade de trabalhar } \\
\text { aqui. Inclusive por três vezes eu estive aqui e næa conseguia falar com a supervisora geral da enfermagem, } \\
\text { porque ela sempre estava ocupada, mas da quarta vez eu consegui. Conversei com ela e ela: "tudo bem, eu vou } \\
\text { te dar uma chance, e se você for bem a gente faz a contrataçăo". Fiquei dois meses como } 3131 \text {, depois fui para } \\
733 \text {, fui duas vezes } 733 \text {. Eu prestei concurso nesta época e entrei como concursada. Hoje eu sou concursada. Eu } \\
\text { sempre quis trabalhar em hospital, em especializaça hospitalar. Eu morava perto do Hospital das Clinicas, e eu } \\
\text { sempre tive vontade de trabalhar em hospital e, esse hospital aqui acabou acontecendo na minha vida, e eu } \\
\text { gostei muito. Veio bem de encontro com o que eu estava desejando. Sujeitos: (AE1, AE2, P1) }\end{array}$ \\
\hline
\end{tabular}

Líderes Setoriais de Acolhimento

Eu tinha um sonho de ingressar na maternidade, trabalhar na maternidade. Eu era atendente. Comecei como em um posto de saúde perto da minha casa, depois eu fiz o curso de auxiliar de enfermagem que foi gosto de maternidade, eu gosto de trabalhar na maternidade. Este Hospital já estava na minha trilha faz muito tempo. Desde a época que estudava eu tinha colegas que trabalhavam aqui, eu tinha muita vontade de trabalhar aqui. Inclusive por três vezes eu estive aqui e não conseguia falar com a supervisora geral da enfermagem, porque ela sempre estava ocupada, mas da quarta vez eu consegui Conversei com ela e ela: "tudo bem, eu vou te dar uma chance, e se você for bem a gente faz a contratação". Fiquei dois meses como 3131, depois fui para 733, fui duas vezes 733. Eu prestei concurso nesta época e entrei como concursada. Hoje eu sou concursada. Eu sempre tive vontade de trabalhar em hospital e esse hospital aqui acabou acontecendo na minha vida e eu gostei muito. Veio bem de encontro com o que eu estava desejando. Sujeitos: (AE1, AE2, P1)

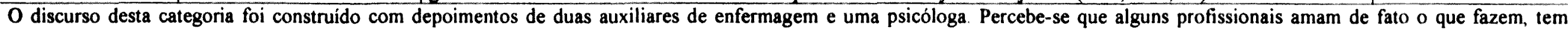
vocação para trabalhar em maternidade e têm consciência dos seus processos de trabalho.

\begin{tabular}{|c|c|c|}
\hline $\begin{array}{c}\text { IDEIA } \\
\text { CENTRALH }\end{array}$ & Médicos (Obstetras, Residentes, Neonatologistas, Anestesiologistas, UTI Materno e Neonatal) & $\begin{array}{l}\text { Direção do } \\
\text { HMI e Amb }\end{array}$ \\
\hline $\begin{array}{l}\text { E um bom hospital } \\
\text { se comparado aos } \\
\text { outros do Estado }\end{array}$ & $\begin{array}{l}\text { Eu gosto muito daqui. Acho que aqui é um hospital que funciona relativamente bem perante os outros que a gente conhece. Por isso é que eu } \\
\text { fico, porque se não, não. Este hospital é um dos melhores dentro do SUS de São Paulo, um hospital bem renomado e, aqui eu sabia que eu ia } \\
\text { aprender bastante na minha profissão, e ia estar preparada depois para atender bem as pacientes e para o mercado de trabalho. Sujeitos: (OS, } \\
\text { RB) }\end{array}$ & \\
\hline
\end{tabular}

deficiências, o HMI é um dos melhores hospitais do Estado 


\section{DISCURSO DO SUJEITO COLETIVO}

\section{Você está satisfeita (o) com o que você vem desempenhando aqui? $O$ que precisa ser melhorado?}

\begin{tabular}{|c|c|c|}
\hline $\begin{array}{c}\text { IDEIA } \\
\text { CENTRALA }\end{array}$ & $\begin{array}{c}\text { Médicos (Obstetras, Residentes, Neonatologistas, } \\
\text { Anestesiologistas, UTI Materno e Neonatal) }\end{array}$ & Direção do HMI e Ámbulatório \\
\hline $\begin{array}{c}\text { Está } \\
\text { Medianamente } \\
\text { satisfeito, pois } \\
\text { tem } \\
\text { expectativas de } \\
\text { mais melhorias }\end{array}$ & $\begin{array}{l}\text { A gente sempre acha que a gente pode desempenhar mais. Eu } \\
\text { acho que eu tenho muita coisa ainda para fazer. Tem muita coisa } \\
\text { que eu posso modificar, que eu posso melhorar, tem muita coisa } \\
\text { que eu posso aprender. Aliás, eu nesse tempo que eu estou na } \\
\text { Maternidade eu estou aprendendo bastante coisa. Então, eu acho } \\
\text { que tem muita coisa ainda para gente poder movimentar e } \\
\text { conseguir um acréscimo profissional muito grande. Mas de uma } \\
\text { maneira geral o nosso trabalho aqui é bastante importante, a } \\
\text { gente vê que a gente faz diferença. Tem algumas coisas que } \\
\text { deveriam ser bem melhores, claro! Todos os serviços têm os seus } \\
\text { defeitos e suas qualidades, é obvio que tem muitos pontos bons, } \\
\text { mas eu acho que falta um pouco para melhorar. Aqui, se eu fosse } \\
\text { falar eu falaria mais em termos de aprendizado, porque eu estou } \\
\text { no aprendizado. Então, eu acharia em termos da humanização do } \\
\text { parto fica dificil porque eu não conheço muito o trabalho do } \\
\text { hospital. } \\
\text { Sujeitos: (N2, N3, RC) }\end{array}$ & $\begin{array}{l}\text { Sempre tem alguma coisa para ser melhorado; quando você está satisfeito praticamente o } \\
\text { processo, ele fica estaguinado, se eu estou satisfeito eu não tenho mais nada para fazer. Então, } \\
\text { satisfeito nós nunca ficamos. O ser humano é um eterno insatisfeito. Gosto muito do que faço e } \\
\text { tenho as habilidades necessárias para desenvolver bem meu trabalho. Quanto a melhorias, } \\
\text { sempre é tempo de adquirir mais conhecimentos. Satisfeito a gente nunca fica, porque você } \\
\text { sempre sabe que dá para fazer mais do que está se fazendo. Só que às vezes nós dependemos de } \\
\text { recursos, tanto materiais, como colaboração de outros profissionais para você desempenhar } \\
\text { melhor, mas atualmente, nós estamos até com uma diretoria nova, então novidades virão por aí, } \\
\text { então eu digo, estou satisfeita no momento sim, mas com certeza podendo fazer muito mais. O } \\
\text { desempenho sempre deve ser melhorado. A busca por mudanças é constante, gostaria de ter a } \\
\text { possibilidade de estabelecer uma maior parceria com as lideranças do HMI, na busca de uma } \\
\text { maior autonomia dos funcionários responsáveis pelos setores. Acredito que ainda apresento uma } \\
\text { postura centralizadora de delegar poderes. Seria fundamental para o processo de humanização. O } \\
\text { trabalho exige constante aprendizado, é diversificado, o contato com um grande número de } \\
\text { pessoas é gratificante. } \\
\text { Sujeitos: (DG, DE, DRH, DA) }\end{array}$ \\
\hline
\end{tabular}

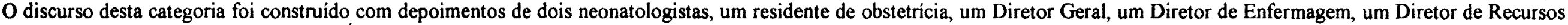
Humanos e um Diretor de Ambulatório. É o sonho de muitos profissionais da Instituição constatar no HMI a implantação da Humanização da Assistência Materno-Neonatal. 


\section{DISCURSO DO SUJEITO COLETIVO}

\section{Você está satisfeita (o) com o que você vem desempenhando aqui? $O$ que precisa ser melhorado?}

\begin{tabular}{|c|c|c|c|}
\hline $\begin{array}{c}\text { IDELA } \\
\text { CENTRALB }\end{array}$ & $\begin{array}{l}\text { Médicos (Obstetras, Residentes, Neonatologistas, Anestesiologistas, } \\
\text { UTI Materno e Neonatal) }\end{array}$ & Direção do HMI e Ambulatório & $\begin{array}{l}\text { Outros profissionais } \\
\text { da área Assistencial }\end{array}$ \\
\hline $\begin{array}{c}\text { Está } \\
\text { satisfeito, } \\
\text { devido } \\
\text { melhora } \\
\text { progressiva } \\
\text { da qualidade } \\
\text { assistencial } \\
\text { na instituição }\end{array}$ & $\begin{array}{l}\text { Da época que eu entrei aqui, até hoje, este hospital só tem a melhorar. Tem } \\
\text { melhorado a cada dia. Aqui é uma maternidade, e em relação ao ano passado } \\
\text { para cá, melhorou muito. Nós estamos implantando agora a humanização do } \\
\text { parto, analgesia de parto, tudo que favoreça a mulher. Então, eu estou bastante } \\
\text { satisfeito aqui. As condutas eu achei que foram melhoradas na parte de } \\
\text { humanização propriamente dita. Eu acho que melhorou bastante. O pessoal } \\
\text { está interessado em melhorar na parte teórica da coisa, mas tem que por em } \\
\text { prática isso. Acho que já, melhorou muito do ano passado para cá. Eu estou } \\
\text { gostando bastante. Eu acho que aqui é um hospital muito bom, dá para } \\
\text { aprender bastante coisa na parte de obstetricia, tem muito volume, tem muitos } \\
\text { casos de alto risco. Então, eu estou satisfeita por ter escolhido aqui, eu acho } \\
\text { que dá para aprender bastante neste hospital aqui. Sujeitos: (RD, Al, RA) }\end{array}$ & $\begin{array}{l}\text { Pessoalmente estou satisfeito, mas eu acredito que } \\
\text { algumas pessoas não. Atualmente a área fisica precisa ser } \\
\text { melhorada, depois encampamento mais de serviço. } \\
\text { Comparando de sete anos para cá, isso aqui evoluiu } \\
1.000 \% \text {. A gente já realizou diversos trabalhos, a gente } \\
\text { melhorou uma série de outras coisas e técnicas. Nós } \\
\text { conquistamos um avanço em relação a parte técnica dos } \\
\text { nossos profissionais. Nós estamos limitados hoje pela área } \\
\text { fisica e estamos limitados simplesmente porque nós não } \\
\text { temos como encampar mais serviços ao cliente. O objetivo } \\
\text { da administração seria de que tivéssemos espaço e ai a } \\
\text { gente abriria novos serviços, melhoraria mais ainda a } \\
\text { assistência. Sujeitos: (DC) }\end{array}$ & $\begin{array}{l}\text { Estou muito satisfeita } \\
\text { Eu acho que no meu } \\
\text { exercicio, nada precisa } \\
\text { ser mudado, claro que eu } \\
\text { procuror sempre } \\
\text { melhorar, sempre inovar } \\
\text { e sempre trazer coisas } \\
\text { novas para cá. } \\
\text { Sujeitos: (P1) }\end{array}$ \\
\hline
\end{tabular}

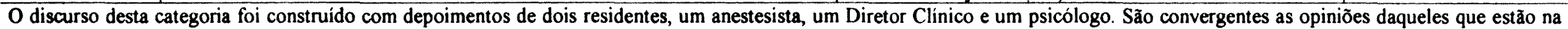
instituiçăo desde a sua abertura, da progressiva melhora da qualidade assistencial do Hospital apesar da sua estrutura fisica inadequada.

\begin{tabular}{|c|c|c|}
\hline $\begin{array}{c}\text { IDEIA } \\
\text { CENTRALC }\end{array}$ & Médicos (Obstetras, Residentes, Neonatologistas, Anestesiologistas, UTI Materno e Neonatal) & $\begin{array}{r}\text { Direcão do } \\
\text { HMI e A mb. }\end{array}$ \\
\hline $\begin{array}{c}\text { Está } \\
\text { regularmente } \\
\text { satisfeito } \\
\text { devido } \\
\text { consultas de } \\
\text { pré-natal no } \\
\text { P. Socorro }\end{array}$ & $\begin{array}{l}\text { A nivel de Pronto Socorro, aqui, a gente faz muita consulta de pré-natal. Então, daria para aliviar e a gente dar uma atenção maior lá para cima, } \\
\text { para os casos que realmente necessitam da nossa atenção e a gente acaba atendendo muito ambulatório aqui em baixo. A gente atende até a hora } \\
\text { do almoço } 60 \text { consultas. A maioria são consultas de ambulatório, eu apontaria ai } 40 \% \text { de consultas de ambulatório. Tanto que a maioria não fica, } \\
\text { a maioria acaba indo embora, a gente acaba drenando, vem gente dizendo que está com atraso menstrual, com queixa que não é de PS e a gente } \\
\text { acaba perdendo um tempão aqui, sendo que lá em cima você sabe como que é, que requer bastante a nossa atenção e a gente acaba ficando aqui. } \\
\text { Mas ai é mais o lado de conscientização da paciente. Eu acho que não é porque aqui não funciona bem, muito pelo contrário. A nível de porta eu } \\
\text { acho que deveria ter um médico que só fizesse a triagem e dissesse: "você vai passar, você eu vou encaminhar para o ambulatório", para só } \\
\text { agilizar o atendimento. A nivel de pré-parto eu acho que funciona bem, eu acho que agora depois de muitas melhoras dos profissionais. No } \\
\text { começo era muito difícil. Agora melhorou muito, eu não tenho muito o que falar do Pré-Parto e do Centro Obstétrico. Sujeitos: (O5) }\end{array}$ & \\
\hline
\end{tabular}




\section{DISCIRSO DO SUJEITO COIEIIVO}

\section{Você está satisfeita (o) com o que você vem desempenhando aqui? O que precisa ser melhorado?}

\begin{tabular}{|c|c|}
\hline $\begin{array}{c}\text { IDELA } \\
\text { CENTRAL D }\end{array}$ & Direçăo do HMI e Ambulatório \\
\hline $\begin{array}{c}\text { Tem muitos } \\
\text { profissionais } \\
\text { doentes e } \\
\text { readaptados } \\
\text { na instituição } \\
\text { e não } \\
\text { existem } \\
\text { outros para } \\
\text { substituí-los }\end{array}$ & $\begin{array}{l}\text { A defasagem de funcionários é muito grande, é complicado isso. Quer dizer, a gente tem bastante funcionário em licença médica. A } \\
\text { maioria dos funcionários da Rede Pública por serem concursados, são funcionários que já estão numa idade um tanto avançada e não tem } \\
\text { gente para repor o lugar. Hoje eu estava comentando com as meninas que eu não sei mais o que fazer, eu cheguei a um ponto que eu não sei } \\
\text { mais o que fazer. Tem profissionais que precisam de assistência psicológica e/ou psiquica. Inclusive eu estou com um auxiliar de } \\
\text { enfermagem que foi passar por uma avaliação porque tem problemas psiquiátricos e ele está proibido de exercer a função. Precisava estar } \\
\text { viabilizando assistência psicologia para alguns profissionais. Precisaria sim, mas isso não deveria ser melhorado somente aqui para o } \\
\text { Hospital, deveria ser melhorado na Rede. Deveria existir na rede um local especifico para tal. Existe assistência no Hospital do Servidor } \\
\text { Estadual, mas não funciona, não dá conta da demanda. É muito complicado uma psicóloga atender o próprio funcionário de dentro da } \\
\text { mesma instituição a qual ela trabalha, porque o funcionário pode achar a qualquer momento que a pessoa está perseguindo ela por causa } \\
\text { dos problemas. Deveria existir uma estrutura independente do Hospital, onde pudesse estar sendo trabalhado estes profissionais na área da } \\
\text { saúde. Os funcionários se negam a ir para o Servidor porque dizem que lá demora no atendimento, não tem vaga. Os funcionários que } \\
\text { ficam na casa, devido uma pressão de acúmulo de serviço, começam a sofre uma pressão psicológica muito grande, um estresse emocional } \\
\text { muito grande. Porque os que ficam tem que fazer as suas atividades e mais as do que estão de licença. Os funcionários estão passando por } \\
\text { um processo geral de envelhecimento, de adoecimento. Para senhora ter uma idéia eu já tive plantão em que tinham três auxiliares de } \\
\text { enfermagem no Alojamento Conjunto com quarenta pacientes. É sub-humano isso de você ter três auxiliares de enfermagem para cuidar de } \\
\text { quarenta mães e de quarenta bebês O que mais precisaria estar trabalhando mesmo é a consciência das pessoas. Sujeitos: (DE, SE) }\end{array}$ \\
\hline
\end{tabular}

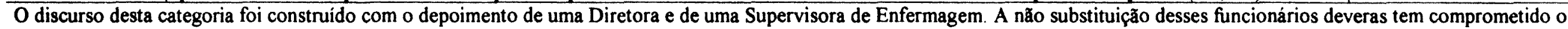

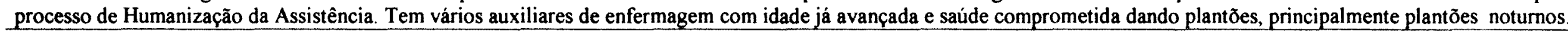

\begin{tabular}{|c|c|c|c|}
\hline $\begin{array}{c}\text { IDEIA } \\
\text { CENTRALE }\end{array}$ & $\begin{array}{c}\text { Profissionais da área } \\
\text { Administrativa }\end{array}$ & Outros profissionais da área Assistencial & $\begin{array}{l}\text { Líderes Setoriais } \\
\text { de Acolhimento }\end{array}$ \\
\hline $\begin{array}{l}\text { Com a presença do R1 e do R2 a } \\
\text { enfermeira obstetrica não está } \\
\text { tendo a oportunidade de fazer } \\
\text { parto, só atuando no pré-parto }\end{array}$ & & $\begin{array}{l}\text { Eu acho que precisa ser melhorado, com certeza. Ultimamente está tendo } \\
\text { Residente, são dois R1, que ficam no pré-parto e um R2, então a gente não está } \\
\text { tendo mais a oportunidade de fazer o parto como a gente fazia antes. A gente está } \\
\text { mais acompanhado o parto, e o pré-parto, praticamente não fazemos mais parto. } \\
\text { Sujeitos: (E5) }\end{array}$ & \\
\hline
\end{tabular}




\section{DISCURSO DO SUJEITO COLETIVO}

Você está satisfeita (o) com o que você vem desempenhando aqui? O que precisa ser melhorado?

\begin{tabular}{|c|c|c|}
\hline $\begin{array}{c}\text { IDEIA } \\
\text { CENTR.ALF }\end{array}$ & Direção do HMI e A mbulatório & $\begin{array}{c}\text { Lideres Setoriais de } \\
\text { Acolhimento }\end{array}$ \\
\hline $\begin{array}{l}\text { A humanização } \\
\text { iniciará quando os } \\
\text { profissionais } \\
\text { tomarem } \\
\text { consciência do seu } \\
\text { papel na } \\
\text { instituicão }\end{array}$ & $\begin{array}{l}\text { Acho que quando as pessoas tomarem consciência do papel delas na instituição e como tratar o próximo, a instituição } \\
\text { melhora. Porque estruturalmente tem profissionais de boa qualidade aqui, a única coisa ruim que tem aqui é o descaso com o } \\
\text { paciente e com o colega. O problema está nas pessoas e não na instituição. Uma coisa que eu tento fazer para melhorar é } \\
\text { levantar a auto-estima do funcionário, tentar estar trabalhando isso, só que eu não vou falar para você que é fácil, porque não } \\
\text { é fácil, é dificil porque a maioria deles não querem ser ajudados. Isso desanima, você chega uma hora que você fala: "eu já } \\
\text { estou cansada, eu tento, eu me mato de fazer as coisas para ajudar e não consigo". O maior problema é que as pessoas olham } \\
\text { muito para o umbigo delas e não costumam olhar para o que se passa ao redor. Então, se o meu colega está ali sendo } \\
\text { prejudicado, problema dele. Não é a grande maioria, mas tem. Eu não sei mais o que fazer. Sujeitos: (DE) }\end{array}$ & $\begin{array}{l}\text { A auxiliar de enfermagem fica } \\
\text { chamando, pois o médico } \\
\text { demora no atendimento e } \\
\text { quando vem manda para } \\
\text { remoção e como é tarde e já } \\
\text { não tem mais ônibus os } \\
\text { acompanhantes ficam muito } \\
\text { nervosos. }\end{array}$ \\
\hline
\end{tabular}

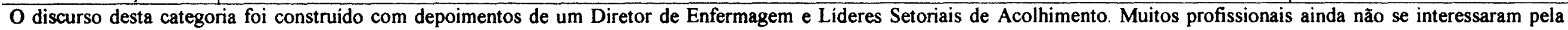

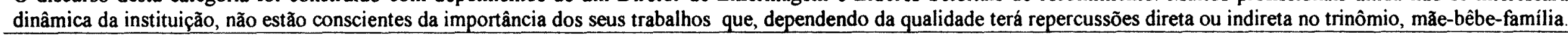

\begin{tabular}{|c|c|c|}
\hline $\begin{array}{c}\text { IDELIA } \\
C E N T R A L G\end{array}$ & Profissionais da área Administrativa & $\begin{array}{l}\text { Outros profissionais } \\
\text { da área Assistencial }\end{array}$ \\
\hline $\begin{array}{l}\text { Está satisfeito } \\
\text { porque está } \\
\text { atuando na } \\
\text { área e com } \\
\text { pessoas que } \\
\text { gosta }\end{array}$ & $\begin{array}{l}\text { Em primeiro lugar, estou muito satisfeita porque o pessoal do DP, posso dizer que nós somos muito unidas. A gente trabalha aqui não só } \\
\text { como colegas de trabalho, a gente tem uma amizade. Além disso, é um pessoal que a gente se dá muito bem, então nosso trabalho rende } \\
\text { quando você trabalha num lugar que você se sente bem, e eu me sinto muito bem trabalhando aqui com elas. Eu gosto muito de trabalhar } \\
\text { em RH, e agora eu estou me formando em pedagogia, com habilitação em RH, então tudo veio a encaixar. Então, eu gosto de RH, e } \\
\text { gosto das amizades que eu tenho aqui dentro, são espetaculares, então eu não tenho nada contra, e isso vem ajudar muito, porque se você } \\
\text { trabalha num bom ambiente tudo vem a satisfazer. Então eu me sinto bem aqui, trabalhando aqui, minhas colegas colaboram comigo, } \\
\text { para mim é o suficiente. O ambiente de trabalho é bom. Muito bom. Totalmente bom. É bem a minha cara mesmo, eu não consigo nem } \\
\text { imaginar sair daqui. Adoro, adoro, adoro. Tenho paixão por aqui. Eu sei que é muito trabalho com o público, mas aqui é só trabalhar com } \\
\text { o público mesmo. Eu trabalhava em contas, trabalhei em vendas, trabalhei em mercado, trabalhei em um monte de coisas. Só que é aqui é } \\
\text { uma coisa do lado carente, são as necessidades deles, a gente sempre consegue satisfazer eles. Não é tão dificil você agradar um usuário } \\
\text { dentro do hospital. Pelo menos na minha parte eu acho que não. Eu estou muito contente mesmo. Não pretendo de forma alguma sair } \\
\text { daqui. Eu gosto daqui, eu gosto das pessoas daqui. É muito bom. O pessoal é muito gente fina mesmo. Gosto muito. Gosto do ambiente. } \\
\text { Eu sempre fui muito bem tratada. Sujeitos: (OA2. OA3, OA5, AL1, AL2, AL3) }\end{array}$ & \\
\hline
\end{tabular}




\section{DISCURSO DO SUJEITO COLETIVO}

\section{Você está satisfeita (o) com o que você vem desempenhando aqui? O que precisa ser melhorado?}

\begin{tabular}{|c|c|c|}
\hline $\begin{array}{c}\text { IDEIA } \\
\text { CENTR } A L H\end{array}$ & $\begin{array}{l}\text { Profissionais da área } \\
\text { Administrativa }\end{array}$ & Outros profissionais da área Assistencial \\
\hline $\begin{array}{c}\text { Não está } \\
\text { satisfeito. É } \\
\text { emergente } \\
\text { melhorar o } \\
\text { relacionamento } \\
\text { humano na } \\
\text { instituição }\end{array}$ & $\begin{array}{l}\text { Os seguranças estão } \\
\text { preocupados com suas escalas, } \\
\text { quando falta funcionário, fica } \\
\text { obrigando o funcionário a ficar } \\
\text { só no setor sem condição de } \\
\text { trabalho O funcionário precisa } \\
\text { comer, ir ao banheiro e levar } \\
\text { exames no laboratório. } \\
\text { Sujeitos: (S4) }\end{array}$ & $\begin{array}{l}\text { Em primeiro lugar, eu acho que precisaria ser melhorado o relacionamento humano. Falta } \\
\text { muito aqui. Eu acho que a gente precisa levantar uma bandeira branca que está faltando } \\
\text { aqui. Precisa ter mais contato, mais conversa, mais diálogo entre nós. Eu acho que existe } \\
\text { pouca comunicação entre todas as categorias de todos os profissionais. A gente precisava } \\
\text { conversar mais, sentar mais, em vez de uma querer puxar o tapete da outra que existe } \\
\text { muito e não é só aqui não, são em todos os setores. Em vez das pessoas verem os erros dos } \\
\text { outros elas verem as qualidades, em vez de apontar os erros tem que apontar as qualidades. } \\
\text { A hora que ver um erro não ir levar o erro para chefia e dizer: "olha eu acho que isto aqui } \\
\text { não está bom, o que você acha se a gente fizer isso ou fizer aquilo para mudar?". Resolver } \\
\text { as falhas internamente. Satisfeito a gente nunca está. Eu acho que à medida que a gente vai } \\
\text { trabalhando e conversando com os parceiros dentro da instituição, nós vamos a cada dia, } \\
\text { colhendo frutos e aglutinando pessoas que tenham o mesmo espirito e daquelas que não } \\
\text { tem, com a nossa insistência a gente começa a ver que as pessoas vão começando a se } \\
\text { integrar nesta questão da humanização, porque a nossa formação na verdade foi muito } \\
\text { intervencionista. E apesar de eu ter tido uma formação mais intervencionista, sempre eu } \\
\text { busquei esta parte, esta outra parte da humanização. E tem outras pessoas que ainda } \\
\text { continuam, desenvolvendo uma dessas atividades intervencionistas, então nós temos que } \\
\text { mudar isto. Então, tem horas que "a insatisfação é a marca do progresso". O fato de você } \\
\text { está insatisfeito, é um estimulo que te motiva a melhorar cada dia que passa. Então, eu não } \\
\text { estou satisfeito, eu quero mais ainda melhorar o trabalho, melhorar o atendimento. A gente } \\
\text { está com alguns projetos, e a diretoria tem conhecimento desse projeto de melhorar o } \\
\text { nosso atendimento aqui. Sujeitos: (E1, F2, E2) }\end{array}$ \\
\hline
\end{tabular}

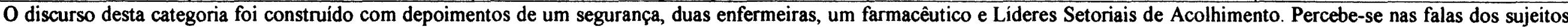

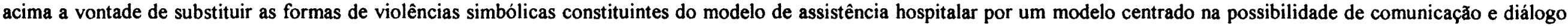

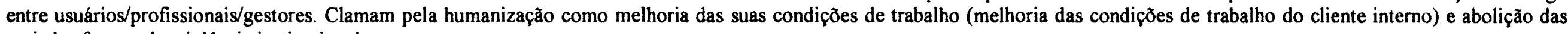
variadas formas de violência institucional. 


\section{DISCURSO DO SUJEITO COL ETIVO}

\section{O que você entende por Humanização da Assistência Materno-Neonatal?}

\begin{tabular}{|c|c|c|c|}
\hline $\begin{array}{c}\operatorname{IDE} I A \\
C E N T R I L A\end{array}$ & $\begin{array}{l}\text { Médicos (Obstetras, Residentes, Neonatologistas, } \\
\text { Anestesiologistas, UTI Materno e Neonatal) }\end{array}$ & $\begin{array}{c}\text { Direçao do } \\
\text { HMI e } \\
\text { Ambulatório }\end{array}$ & Profissionais da área Administrativa \\
\hline $\begin{array}{c}\text { Atender bem } \\
\text { as pacientes, } \\
\text { desde a sua } \\
\text { admissão no } \\
\text { hospital até a } \\
\text { sua alta }\end{array}$ & 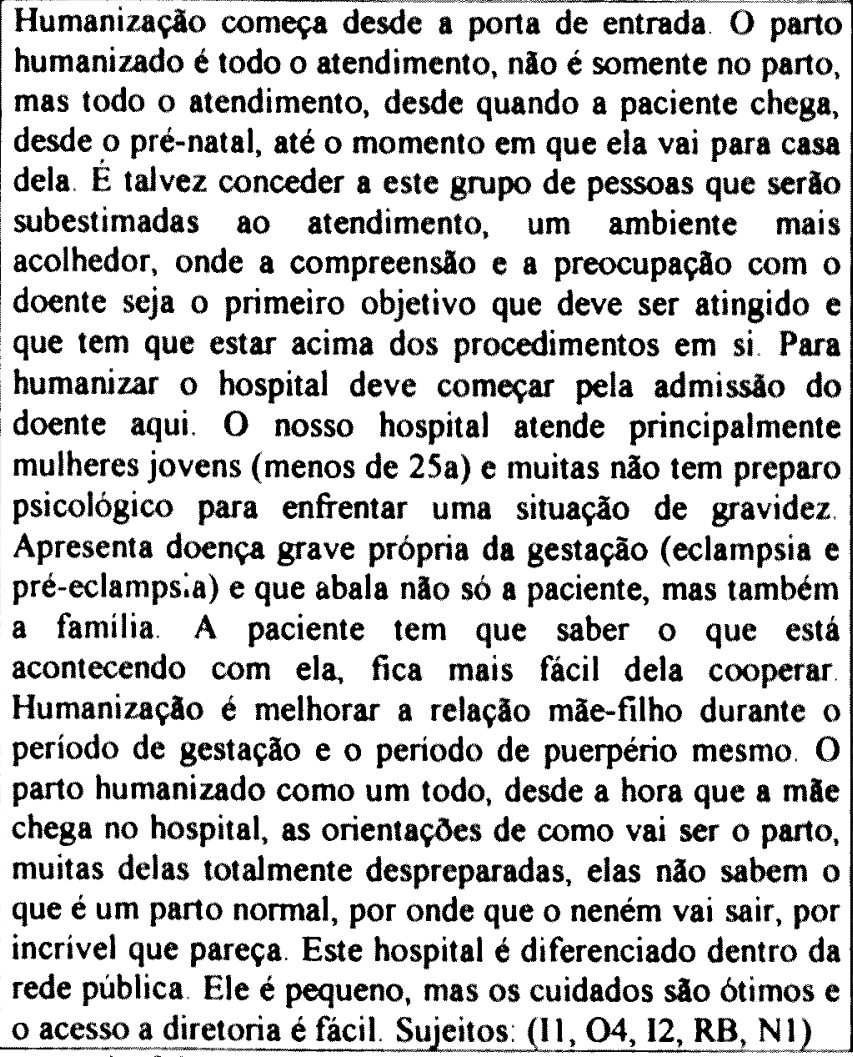 & 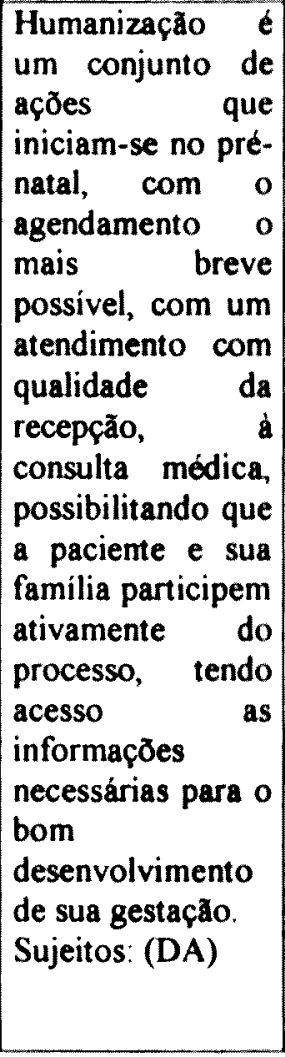 & 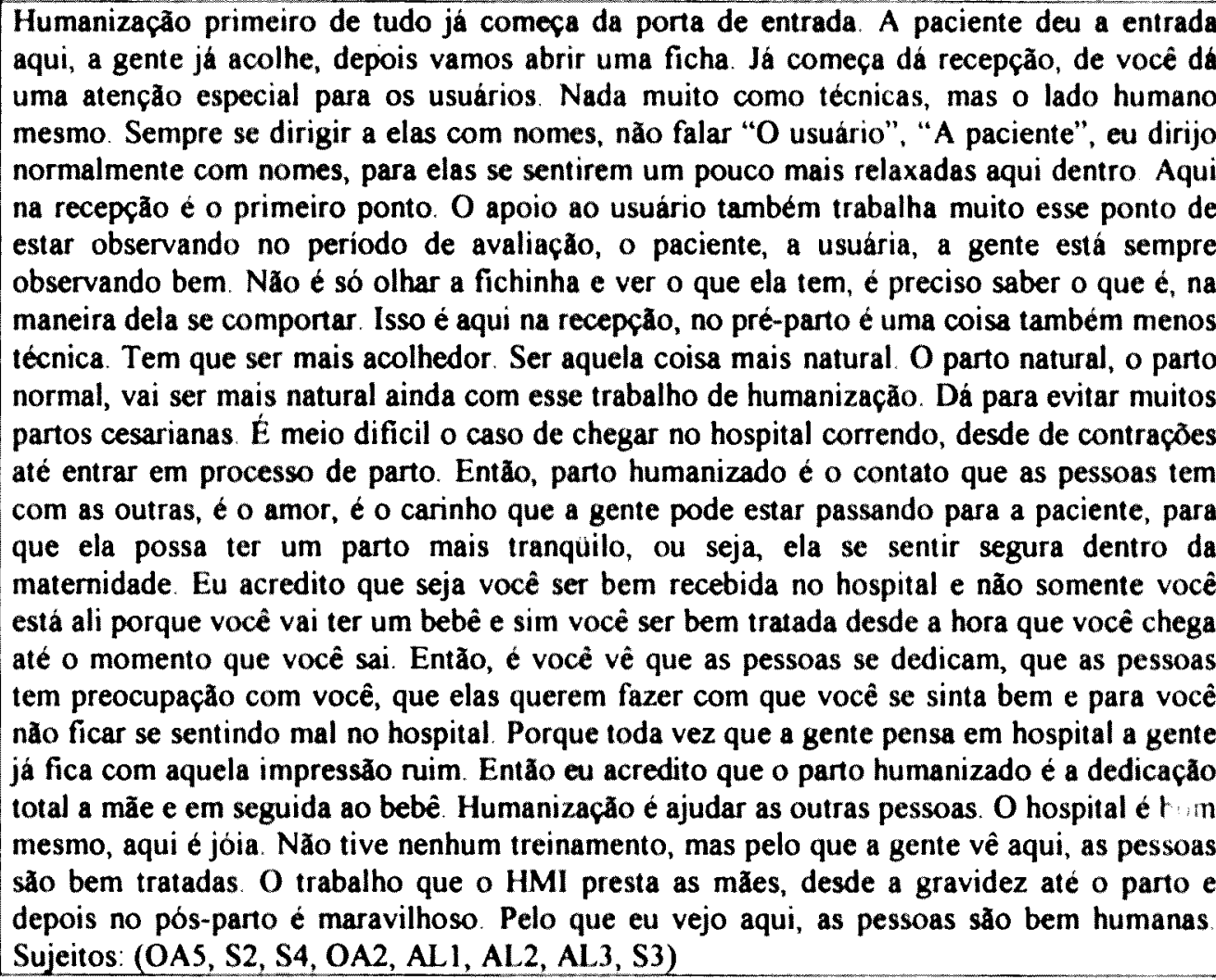 \\
\hline
\end{tabular}

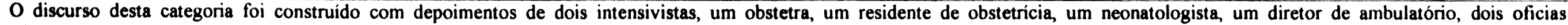
administrativos, três seguranças e três auxiliares de limpeza. 


\section{DISCIRSO DO SUJEITO COI ETIVO}

\section{O que você entende por Humanização da Assistência Materno-Neonatal?}

\begin{tabular}{|c|c|c|}
\hline $\begin{array}{c}\text { IDELA } \\
\text { CENTRALB }\end{array}$ & $\begin{array}{c}\text { Médicos (Obstetras, Residentes, Neonatologistas, } \\
\text { Anestesiologistas, UTI Materno e Neonatal) }\end{array}$ & Outros profissionais da área Assistencial \\
\hline $\begin{array}{c}\text { Parto com mãe } \\
\text { e filho } \\
\text { saudáveis }\end{array}$ & $\begin{array}{l}\text { O parto normal logo quando o neném nasce com uma nota boa, ele } \\
\text { está do lado da mãe, ele se sente melhor, ele se aquece mais rápido, } \\
\text { ele não tem aqueles efeitos de frio, alguns efeitos que a gente } \\
\text { provoca, faz o neném a ser submetido por afastamento da mãe. Parto } \\
\text { humanizado é oferecer uma boa assistência, tanto para mãe como } \\
\text { para o bebê, para que ambos, saiam muito bem. A mãe passa nove } \\
\text { meses esperando o neném, ela espera sair daqui com o bebê em bom } \\
\text { estado assim como ela chegou, porque ela esperou nove meses por } \\
\text { isso. } \\
\text { Sujeitos: }(\mathrm{N} 1, \mathrm{~N} 4, \mathrm{RC})\end{array}$ & $\begin{array}{l}\text { Parto humanizado é o que é melhor para mãe e para o neném. Eu entendo assim. Parto } \\
\text { humanizado é aquele parto que seria melhor para a paciente, para ela ter a opção de escolher } \\
\text { aquilo que é melhor para ela. Mas parto humanizado, é aquele calor humano que você dá } \\
\text { para paciente, é ela poder escolher, ter liberdade, que todo mundo tem que ter a sua } \\
\text { liberdade de escolha, não chegar lá, colocar ela, e você vai fazer isso, você vai fazer aquilo, } \\
\text { de repente não é bom para ela. Eu acho que é fundamental, é super importante. O parto } \\
\text { humanizado é bom para mãe, para o bebê e para toda a sociedade. Tem que ser mais } \\
\text { divulgado, ter mais enfermeiras obstétricas, mais médicos conscientes do que é } \\
\text { humanização, tem muitas palestras, mas muitos são a favor, outros não são a favor. } \\
\text { Sujeitos: (E7, E8) }\end{array}$ \\
\hline
\end{tabular}

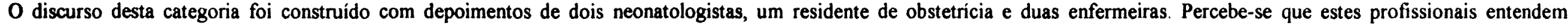
humanização como a capacidade de oferecer atendimento de qualidade articulando os avanços tecnológicos com o bom relacionamento 


\section{DISCURSO DO SUJEITO COLETIVO}

\section{O que você entende por Humanização da Assistência Materno-Neonatal?}

\begin{tabular}{|c|c|c|}
\hline $\begin{array}{c}\text { IDELA } \\
\text { CENTRALC }\end{array}$ & $\begin{array}{l}\text { Médicos (Obstetras, Residentes, Neonatologistas, } \\
\text { Anestesiologistas, UTI Materno e Neonatal) }\end{array}$ & $\begin{array}{l}\text { Direçåo do HMI } \\
\text { e Ambulatório }\end{array}$ \\
\hline $\begin{array}{l}\text { A mulher ter } \\
\text { um parto o } \\
\text { mais natural } \\
\text { possível }\end{array}$ & $\begin{array}{l}\text { O parto ć um processo natural, é um parto que a parturiente se } \\
\text { sinta bem sem passar pelos mecanismos e por situaçães que a } \\
\text { levem ao constrangimento. É a mãe ter o neném o mais natural } \\
\text { possível. Já é o momento do nascimento do filho, a família está, } \\
\text { um amigo dando atenção a mulher, um enlace familiar muito } \\
\text { gostoso no momento do nascimento da criança, a criança } \\
\text { sentindo a presença do pai, e da mãe, e essa humanização, tudo } \\
\text { leva a crer que há melhora da paciente rápida, ela tem uma } \\
\text { recuperação muito rápida e diminui o tempo de internação dela. } \\
\text { Sujeitos: }(\mathrm{O} 3, \mathrm{~A} 1)\end{array}$ & $\begin{array}{l}\text { E a forma natural de } \\
\text { nascer e ser recebido } \\
\text { pelo mundo. E o } \\
\text { nascer bem } \\
\text { dignamente. } \\
\text { Sujeitos: (DU) }\end{array}$ \\
\hline
\end{tabular}

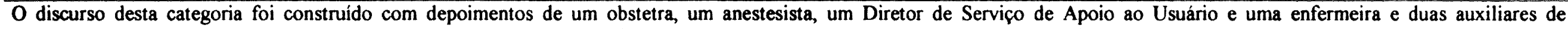
enfermagem. Estes profissionais tem a mulher como a protagonista principal do parto. Compreendem o evento como de muita significação para a mulher e sua família.

\begin{tabular}{|c|c|c|}
\hline $\begin{array}{c}\text { IDEIA } \\
\text { CENTRAL D }\end{array}$ & Médicos (Obstetras, Residentes, Neonatologistas, Anestesiologistas, UTI Materno e Neonatal) & $\begin{array}{c}\text { Direção do HMI e } \\
\text { Ambulatório }\end{array}$ \\
\hline $\begin{array}{l}\text { Visita prévia a } \\
\text { maternidade onde } \\
\text { vai ter o filho }\end{array}$ & $\begin{array}{l}\text { Desde a hora que ela chega no hospital, que ela conhece o hospital, conhece o berçário, e é conversado com ela ,os } \\
\text { médicos, os ginecologistas, os neonatologistas, tirado as informaçð̃es sobre a gravidez, explicado passo a passo como que } \\
\text { vai ser a condução do caso dela, do parto dela, ela se sente mais segura, na hora ela fica mais tranqüila, apesar de todas as } \\
\text { dores. Sujeitos: (N1) }\end{array}$ & \\
\hline \multicolumn{3}{|c|}{ 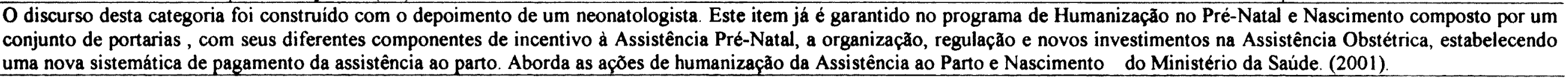 } \\
\hline
\end{tabular}




\section{DISCIRSO DO SUJEITO COI.ETIVO}

\section{O que você entende por Humanização da Assistência Materno-Neonatal?}

\begin{tabular}{|c|c|c|}
\hline $\begin{array}{c}\text { IDEIA } \\
\text { CENTRALE }\end{array}$ & Médicos (Obstetras, Residentes, Neonatologistas, Anestesiologistas, UTI Materno e Neonatal) & $\begin{array}{l}\text { Direçå do HMI } \\
\text { e Ambulatório }\end{array}$ \\
\hline $\begin{array}{c}\text { Contato } \\
\text { precoce mãe- } \\
\text { bebê (Vínculo } \\
\text { satisfatório } \\
\text { mãe-bebê) }\end{array}$ & $\begin{array}{l}\text { O momento do parto não é um momento făcil para a mulher e ela se sente mais segura, ela fica mais tranquila e tende a correr mais } \\
\text { tranqüilamente esse parto. E o neném logo que nasce, já ficando ao lado dela, para o neném é excelente, parto normal para o neném é } \\
\text { melhor. Até um tempo atrás o neném nascia super bem, com uma nota alta, e rapidamente eles já eram afastados da mãe, hoje a gente vê } \\
\text { que os bebezinhos que nascem bem, com o pediatra ao lado avaliando o nascimento da criança, para ver se eles têm um apgar bom, esses } \\
\text { bebês não precisam ser afastados da mãe logo ao nascimento, isso ocorre um rompimento materno-fetal. Então o importante é o neném } \\
\text { nascer, e ser colocado logo no colo da mãe, ser estimulado a amamentação, esse contato pele a pele é muito importante para o neném. É um } \\
\text { trabalho que as maternidades agora vem desenvolvendo e eu acho extremamente importante, que é o contato precoce da mãe com o filho na } \\
\text { hora de fazer o parto. Realmente melhora muito as condiç̃es do bebê, tanto condições fisicas quanto psicológicas, o bebê se sente muito } \\
\text { mais aceito, muito mais acolhido, muito mais protegido e isso influencia depois no desenvolvimento da criança. } \\
\text { Sujeitos: (NI, RB) }\end{array}$ & $\begin{array}{l}\text { Năo dá para descolar a } \\
\text { mãe da criança, do } \\
\text { recém-nascido. Apesar } \\
\text { da criança ter nascido, } \\
\text { o binômio não pode } \\
\text { ser separado. As açðes } \\
\text { estão intimamente } \\
\text { ligadas. } \\
\text { Sujeitos: (DG) }\end{array}$ \\
\hline
\end{tabular}

\begin{tabular}{|c|c|c|}
\hline $\begin{array}{c}\text { IDEIA } \\
\text { CENTRALF }\end{array}$ & $\begin{array}{l}\text { Médicos (Obstetras, Residentes, Neonatologistas, } \\
\text { Anestesiologistas, UTI Materno e Neonatal) }\end{array}$ & Outros profissionais da área Assistencial \\
\hline $\begin{array}{l}\text { Humanização é o parto } \\
\text { assistido pelo médico e } \\
\text { obstetriz e com } \\
\text { analgesia }\end{array}$ & $\begin{array}{l}\text { O meu ponto de vista de humanização, acho que é um pouquinho diferente } \\
\text { do contexto geral da humanizaçăo, humanizaçăo é de preferência a mulher } \\
\text { ter um parto sem dor, um parto com analgesia, que seja conduzido, que o } \\
\text { médico fique do lado, que a obstetriz fique do lado. Pelo menos um dos } \\
\text { dois acompanhe esse parto. E que a partir do momento que possa ter uma } \\
\text { complicação você está do lado para poder intervir. } \\
\text { Sujeitos: (RD) }\end{array}$ & $\begin{array}{l}\text { Talvez o que eu entendo não é o mesmo que os outros profissionais } \\
\text { entendem, porque eu acho que a humanização do parto não vem a calhar } \\
\text { muito com a humanizaça que todo mundo esta fazendo, porque para mim } \\
\text { humanização é não deixar que a paciente sinta dor. A partir do momento que } \\
\text { a paciente sinta dor, que a mãezinha sinta dor para dar o leite para o seu } \\
\text { filho, sinta dor para dar a luz, já não é mais humanização Eu respeito os } \\
\text { outros profissionais, mas esse é o meu ponto de vista. } \\
\text { Sujeitos: (E6) }\end{array}$ \\
\hline \multicolumn{3}{|c|}{ 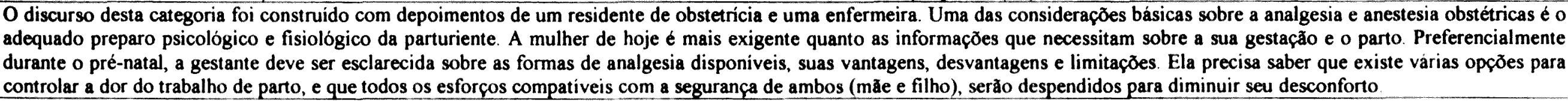 } \\
\hline
\end{tabular}




\section{DISCURSO DO SUJEITO COLETIVO}

\section{O que você entende por Humanização da Assistência Materno-Neonatal?}

\begin{tabular}{|c|c|c|c|}
\hline $\begin{array}{c}\text { IDEIA } \\
\text { CENTR ALG }\end{array}$ & Profissionais da area Administrativa & Outros profissionais da área Assistencial & $\begin{array}{l}\text { Líderes Setoriais } \\
\text { de Acolhimento }\end{array}$ \\
\hline $\begin{array}{c}\text { Devolver ao } \\
\text { parto seu lado } \\
\text { humano que o } \\
\text { excesso de } \\
\text { tecnologia lhe } \\
\text { tirou }\end{array}$ & 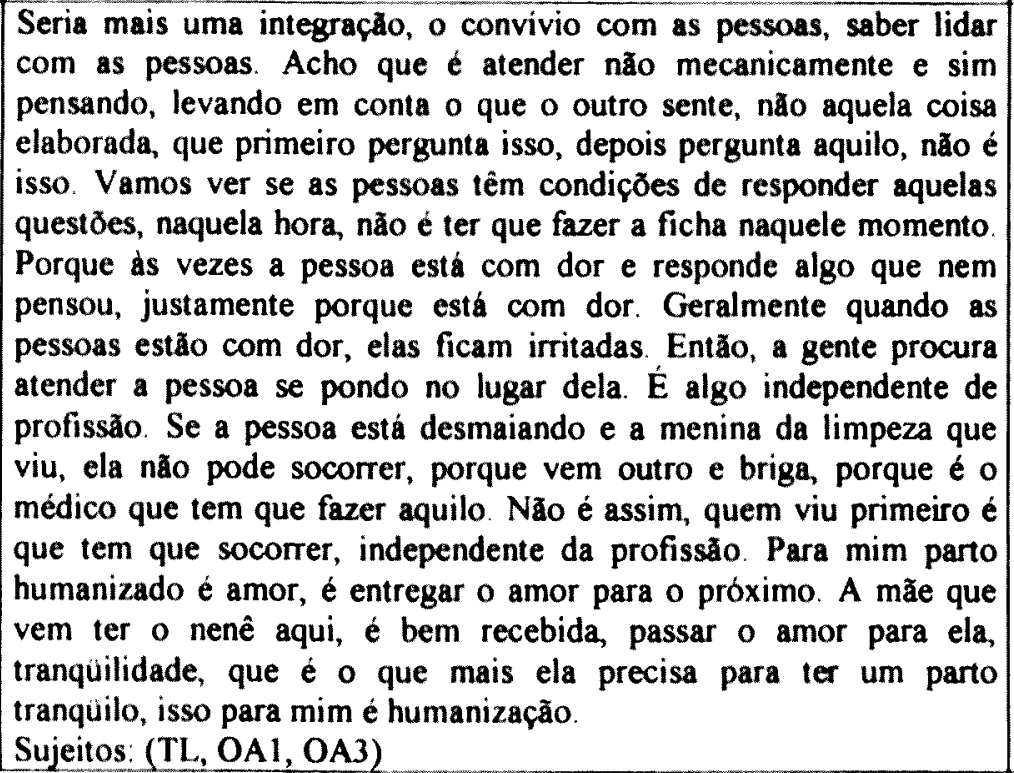 & $\begin{array}{l}\text { E você poder devolver ao parto aquilo que lhe cabe O lado humano } \\
\text { que ele tem. Por conta da tecnologia, referente a máquina e não a } \\
\text { tecnologia humana, que se foi conquistando ao longo dos anos, } \\
\text { ficou um pouco distanciado do lado humano, esse lado das } \\
\text { maquinas, dos equipamentos, essas coisas das técnicas, eu acho que } \\
\text { é extremamente importante. A gente precisa disso. A medicina } \\
\text { contribuiu muito positivamente com isso. Só que agora quando } \\
\text { você pensa muito num lado, estou me especializando, quero } \\
\text { descobrir as máquinas, as técnicas novas, é natural que de repente, } \\
\text { você vai esquecendo um outro lado, que eu acho que com os anos } \\
\text { foi o que aconteceu. E hoje em dia, eu sinto que está acontecendo } \\
\text { uma busca, um retornar, juntar as duas coisas. Agora a gente tem } \\
\text { equipamentos, novas técnicas. Mas também, sabemos que há } \\
\text { importância, de todo o lado humano. A gente está tentando se } \\
\text { recuperar através de um parto humanizado. E eu acho que é } \\
\text { extremamente importante Năo é aquela coisa que você pega. E um } \\
\text { carinho, é uma atençăo } \\
\text { Sujeitos: (PI, F1) }\end{array}$ & \\
\hline
\end{tabular}




\section{DISCURSO DO SUJEITO COLETIVO}

\section{Cite itens de humanização neste hospital.}

\begin{tabular}{|c|c|c|}
\hline $\begin{array}{c}\text { IDEIA } \\
C E N T R A L A\end{array}$ & Médicos (Obstetras, Residentes, Neonatologistas, Anestesiologistas, UTI Materno e Neonatal) & $\begin{array}{c}\text { Direçå do HMI e } \\
\text { Ambulatório }\end{array}$ \\
\hline $\begin{array}{r}\text { Implan } \\
\text { algumas } \\
\text { Humani } \\
\text { Assis } \\
\text { Mat } \\
\text { Neon } \\
\text { aboli } \\
\text { con } \\
\text { proscri } \\
\text { OMS e } N \\
\text { da } S\end{array}$ & $\begin{array}{l}\text { o espaço é muito restrito, o que a gent } \\
\text { amamentação exclusiva é um ponto } \\
\text { faz um bom acolhimento, desde as } \\
\text { profissionais, de todas as áreas são as } \\
\text { eu conheço. Aqui tratam muito melho } \\
\text { do profissional também, mas de uma } \\
\text { que eu pude observar, os nenês logo } \\
\text { amigo da criança. Tudo isso é um em } \\
\text { a proximidade deles, a proximidade } \\
\text { afetivas, um desenvolvimento adequa } \\
\text { criança. Outros pontos importantes s } \\
\text { Materno, todo o empenho que é feitc } \\
\text { amamentar. Tem o "Projeto Canguru } \\
\text { contato direto com o corpo da mãe. } \\
\text { pessoal aqui, a equipe médica, na u } \\
\text { carinhoso, a gente procura ver muito } \\
\text { esses são os pontos mais fortes de } \\
\text { profissionais envolvidos para que }\end{array}$ & $\begin{array}{l}\text { Projetos como: Iniciativa Hospital } \\
\text { Amigo da Criança, Método Mãe } \\
\text { Canguru, Humanização do } \\
\text { Atendimento Hospitalar, CQH, } \\
\text { Grupo de apoio a mães e bebês } \\
\text { internados, favorecem uma } \\
\text { mudança de postura profissional, } \\
\text { melhor atendimento, integração } \\
\text { dos serviços. O HMI, apresenta } \\
\text { um atendimento de qualidade, com } \\
\text { profissionais competentes e } \\
\text { envolvidos com o projeto da } \\
\text { unidade. As dificuldades } \\
\text { encontradas fazem parte de um } \\
\text { processo de formação de um grupo } \\
\text { de funcionários em constante } \\
\text { mudança. O acolhimento que está } \\
\text { sendo implantado agora. } \\
\text { Sujeitos: (DA, DE) }\end{array}$ \\
\hline \multicolumn{3}{|c|}{ 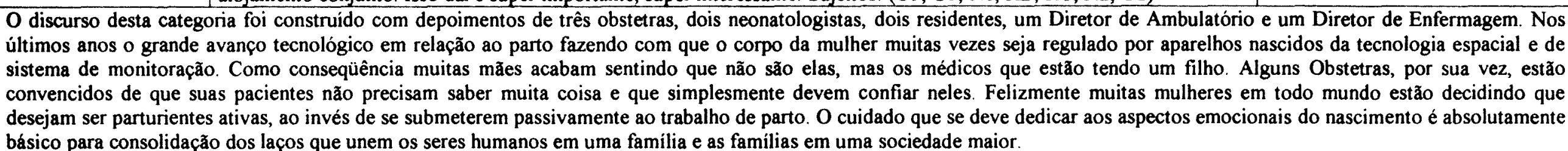 } \\
\hline
\end{tabular}




\section{DISCIRSO DO SUJEITO COI HIIVO}

\section{Cite itens de humanização neste hospital.}

\begin{tabular}{|c|c|c|}
\hline $\begin{array}{c}\text { IDEIA } \\
\text { CENTRALB }\end{array}$ & $\begin{array}{l}\text { Médicos (Obstetras, Residentes, Neonatologistas, } \\
\text { Anestesiologistas, UTI Materno e Neonatal) }\end{array}$ & Direçăo do HMI e Ambulatório \\
\hline $\begin{array}{l}\text { Colaboração e } \\
\text { empenho da } \\
\text { administração } \\
\text { no Processo de } \\
\text { Humanização } \\
\text { da Assistência } \\
\text { Materno- } \\
\text { Neonatal }\end{array}$ & $\begin{array}{l}\text { O estimulo da Diretoria para humanizar o Hospital é ponto de } \\
\text { humanização. O acolhimento da administração com os } \\
\text { profissionais que trabalham aqui melhorou muito. A nova } \\
\text { administração é mais acolhedora, bem mais acolhedora. } \\
\text { Hoje,também estamos ajudando muito nisso, estamos sempre } \\
\text { querendo ser humanos, em relação ao atendimento de qualquer } \\
\text { paciente, de qualquer parente, não só da paciente, mas de } \\
\text { qualquer acompanhante, eles tem necessidade de saber tudo. } \\
\text { Sujeitos: (O3, O5, O1) }\end{array}$ & $\begin{array}{l}\text { Se a gente for citar alguma coisa, muitos podem até achar que não faz parte da humanização, } \\
\text { mas nós temos várias coisas, várias atitudes simples que são pontos de humanização. E o } \\
\text { contato, é o saber do funcionário, é o perguntar, é a troca que a gente tem com alguns } \\
\text { funcionários sobre os problemas da Maternidade, os problemas do funcionário e procurar } \\
\text { atendê-los. Nós já tivemos experiências em vários setores aqui onde antes algumas coisas eram } \\
\text { solicitadas e simplesmente ignoradas, uma simples parede pintada em um setor de lavanderia, ou } \\
\text { de rouparia. Uma má exaustão na cozinha, são coisas que às vezes passam despercebidas. A } \\
\text { gente só pensa em geralmente melhorar o Centro Obstétrico, em melhor sala de parto e } \\
\text { esquecemos realmente de alguns setores. Nós criamos uma sala de atendimento no pronto } \\
\text { socorro, uma sala de atendimento onde, uma sala de atendimento humanizada mesmo, não há } \\
\text { dúvidas. Nós criamos uma sala de atendimento no pronto socorro, uma sala de atendimento, uma } \\
\text { sala de atendimento humanizada mesmo, não há dúvidas. A paciente é acolhida, ela tem onde } \\
\text { ficar com o acompanhante enquanto aguarda a internação, ou aguarda uma possivel remoção. } \\
\text { Nós temos também, nós conseguimos agora um aparelho novo de ultra-sonografia, então nós } \\
\text { temos exames de ultra-sonografia de última geração aqui na própria maternidade para atender as } \\
\text { nossas pacientes. O aparelho de ultra-sonografia estando na Maternidade ele passa a ser } \\
\text { automaticamente de } 24 \text { horas a disposição. A gente está tentando cumprir a risca o programa de } \\
\text { humanização do atendimento. Enquanto elas esperam para fazer o ultra- som, o acompanhante } \\
\text { fica, ele pode ficar na sala do acolhimento. É, Em alguns setores a gente não consegue fazer a } \\
\text { contento por problemas de espaço fisico, mas a gente está programando reformas para esses. } \\
\text { Mas sempre que possivel desde que não atrapalhe o setor, o acompanhante pode ficar junto com } \\
\text { a gestante em todas as atividades da Maternidade. A filosofia da instituição é totalmente voltada } \\
\text { para o atendimento humanizado. }\end{array}$ \\
\hline
\end{tabular}

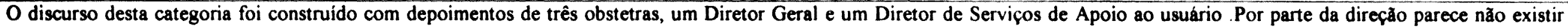
alienaçåo politica na organizaçăo. Senten-se conscientizados do processo de trabalho 


\section{DISCIRSO DO SUJEITO COI EIVO}

Cite itens de humanização neste hospital.

\begin{tabular}{|c|c|c|}
\hline $\begin{array}{c}\text { IDEIA } \\
\text { CENTR.ALC }\end{array}$ & Médicos (Obstetras, Residentes, Neonatologistas, A nestesiologistas, UTI Materno e Neonatal) & $\begin{array}{l}\text { Direcáo do HMI } \\
\text { e A mbulatório }\end{array}$ \\
\hline $\begin{array}{l}\text { Disponibilidade } \\
\text { de analgesia de } \\
\text { parto }\end{array}$ & $\begin{array}{l}\text { Na área da neonatologia, o ponto da humanizaçåo que a gente está fazendo mais uma dinamização, é a analgesia de parto. Em } 1995 \text {,aqui } \\
\text { essa idéia era quase que abolida e hoje em todos os plantões é feito a analgesia de parto, numa base de dez a doze analgésias por } \\
\text { plantão. Eles dão bastante anestesia para parto normal, parto normal sem dor e isso é importante, eles fazem uma analgesia. } \\
\text { Sujeitos. (Al, Nl) }\end{array}$ & \\
\hline
\end{tabular}

\begin{tabular}{|c|c|c|}
\hline $\begin{array}{c}I D E I A \\
C E N T R A L D\end{array}$ & $\begin{array}{l}\text { Médicos (Obstetras, Residentes, Neonatologistas, } \\
\text { Anestesiologistas, UTI Materno e Neonatal) }\end{array}$ & Outros Profissionais da Área Assistencial \\
\hline $\begin{array}{c}\text { Atuação das } \\
\text { voluntárias como } \\
\text { Doulas ("A migas da } \\
\text { Parturiente") }\end{array}$ & $\begin{array}{l}\text { O ponto mais positivo são as voluntárias, as voluntárias aqui } \\
\text { dentro, são os pontos positivos da humanização. } \\
\text { Sujeitos: (O1) }\end{array}$ & $\begin{array}{l}\text { Inclusive o nosso hospital está até trabalhando com as Doulas, que ajudam } \\
\text { também. Infelizmente pela planta fisica não ajudar, não dá para desenvolver tanto, porque } \\
\text { se tem um espaço aqui nesse hospital muito pequeno, então não tem nem como propiciar } \\
\text { melhor conforto para ela. A gente tenta com o que tem, amenizar todos os problemas, } \\
\text { toda aquela dificuldade que ela tem, durante o pré-parto, o momento da dor, estar ao lado } \\
\text { dela na dilataçăo. As doulas ficam junto dela ajudando, a gente tenta trabalhar da melhor } \\
\text { maneira possivel, na medida que se pode. Sujeitos: (E8) }\end{array}$ \\
\hline
\end{tabular}




\section{DISCURSO DO SUJEITO COLETIVO}

\section{Cite itens de desumanização neste hospital.}

\begin{tabular}{|c|c|c|}
\hline $\begin{array}{c}\text { IDEIA } \\
\text { CENTRALA }\end{array}$ & $\begin{array}{c}\text { Médicos (Obstetras, Residentes, Neonatologistas, Anestesiologistas, UTI Materno e } \\
\text { Neonatal) }\end{array}$ & Direçăo do HMI \\
\hline $\begin{array}{l}\text { pres } \\
\text { acom! }\end{array}$ & $\begin{array}{l}\text { principalmente o acompanhante masculino porq } \\
\text { acompanhante a paciente teria que ficar isoladin } \\
\text { Parto deveria ter mais leitos. Muitas vezes a co } \\
\text { onde várias pacientes ficam na mesma sala, is } \\
\text { aspecto assim, todas as pacientes vêem as outras. } \\
\text { pacientes, de dar atenção devida a cada uma, da } \\
\text { atrapalha. Justamente, um pré-parto pequeno, as } \\
\text { inviável você por um acompanhante. Mesmo se } \\
\text { acompanhante junto, fica meio dificil. O nosso pr } \\
\text { parto humanizado, para ter conforto, acolhime } \\
\text { humanizado, tem que ter um acompanhante, e aq } \\
\text { de um monte de mulher em trabalho de parto, qu } \\
\text { vista, colocasse assim, não digo um parto para c } \\
\text { andar. No parto humanizado a gente não coloca o } \\
\text { as pessoas tem como ficar nas posiçðes que ficar } \\
\text { fisica boa para isso. O que mais que pega aqui } \\
\text { bem mesmo para por aqui, mas eu não acho qu } \\
\text { houve casos, por exemplo, da gente ter um pré-pa } \\
\text { cadeiras lá do pré-parto porque não tem mais lei } \\
\text { maior uma sala de parto maior. todas as paci }\end{array}$ & $\begin{array}{l}\text { No momento não tem como entrar o acompanhante } \\
\text { masculino por causa que o pré-parto é coletivo, mas } \\
\text { nós já temos um projeto de fazer uma construção de } \\
\text { uma área anexa e inauguração de sete leitos de PPP } \\
\text { aqui no hospital Næo esqueça que estar o } \\
\text { acompanhante do lado é um fator que você tem como } \\
\text { ajuda, mas também é um fator que vai contaminar e } \\
\text { vai prejudicar a assistência porque você aumenta o } \\
\text { risco de contaminação, a falta de espaço para } \\
\text { movimentação e cria tumulto no ambiente que você } \\
\text { não tem necessidade. Hoje já temos ultimamente um } \\
\text { trabalho realmente muito tumultuado lá em cima } \\
\text { Inclusive as vezes com acesso de paciente na área, } \\
\text { além do próprio médico assistente, do residente, da } \\
\text { enfermagem, certamente é um excesso de pessoal } \\
\text { dentro de uma área muito restrita e pequena e isso faz } \\
\text { com que impeça que entre o acompanhante } \\
\text { independente do sexo masculino ou feminino. Isso } \\
\text { influi demais no ambiente. Se comparar as dimensðes } \\
\text { no pré-parto que cabe seis leitos, realmente eu acho } \\
\text { que nós estamos trabalhando em condições muito } \\
\text { errônea, mas infelizmente a gente não tem muita } \\
\text { opçåo. (DC) }\end{array}$ \\
\hline \multicolumn{3}{|c|}{ 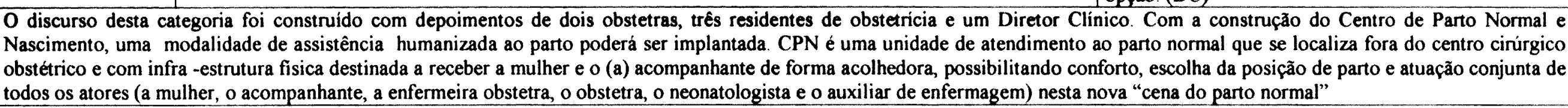 } \\
\hline
\end{tabular}




\section{DISCURSO DO SUJEITO COI.EIIVO}

\section{Cite itens de desumanização neste hospital.}

\begin{tabular}{|c|c|c|c|c|}
\hline $\begin{array}{c}\text { IDEIA } \\
\text { CENTRALB }\end{array}$ & $\begin{array}{c}\text { Direção do HMI e } \\
\text { Ambulatório }\end{array}$ & $\begin{array}{c}\text { Profissionais da Área } \\
\text { Administrativa }\end{array}$ & Outros Profissionais da Área Assistencial & $\begin{array}{c}\text { Lideres Setoriais de } \\
\text { Acolhimento }\end{array}$ \\
\hline $\begin{array}{c}\text { Os } \\
\text { profissionais } \\
\text { nåo se interam } \\
\text { do processo de } \\
\text { trabalho da } \\
\text { instituição }\end{array}$ & $\begin{array}{l}\text { Tem esse ponto das pessoas não se } \\
\text { conscientizarem que são gente, são } \\
\text { outras pessoas que estão ali, } \\
\text { podendo ser um familiar seu, ou } \\
\text { algum conhecido. Mesmo que não } \\
\text { seja, é uma pessoa que está ali, que } \\
\text { merece o mesmo cuidado que você. } \\
\text { Descaso, não vou dizer que são } \\
\text { todos os profissionais, mas alguns } \\
\text { profissionais deixam as pacientes } \\
\text { lá, horas e horas sem dar uma } \\
\text { satisfação para ela do que vai } \\
\text { acontecer com ela, cria uma certa } \\
\text { ansiedade e isso para mim é um } \\
\text { descaso grande. A paciente pode } \\
\text { esperar sim, desde que você chegue } \\
\text { para e explique qual o processo que } \\
\text { vai acontecer e o que vai ser feito } \\
\text { com ela. } \\
\text { Sujeitos: (DRH, DE) }\end{array}$ & $\begin{array}{l}\text { Eu acredito que tenha assim ainda } \\
\text { alguns profissionais que precisam } \\
\text { ser mais conscientes do que seria } \\
\text { um parto humanizado, que tem } \\
\text { alguns profissionais que deixam } \\
\text { muito a desejar no atendimento as } \\
\text { pacientes. Seria a conscientização } \\
\text { destes profissionais, um } \\
\text { treinamento adequado para que } \\
\text { todos eles possam realmente se } \\
\text { dedicar. O profissional ele tem } \\
\text { que realmente se dedicar a fazer } \\
\text { um servico legal. } \\
\text { Sujeitos: (OA2) }\end{array}$ & $\begin{array}{l}\text { As pessoas que não vestem a camisa da instituição, } \\
\text { principalmente os médicos que acham que são deuses. } \\
\text { Inclusive eu tive conversando, com o diretor clínico } \\
\text { no sentido de que, todos os residentes, de que todas as } \\
\text { pessoas viessem estagiar neste hospital, que já é uma } \\
\text { proposta para 2003, que nós déssemos um, fizéssemos } \\
\text { aqui assim uma, exposição para que as pessoas já } \\
\text { saibam qual é a filosofia do hospital. Qual é a } \\
\text { filosofia? O que nós queremos? Qual é a nossa meta? } \\
\text { O que nós precisamos para humanizar? Para que } \\
\text { todos os residentes daqui, todos os estagiários sejam } \\
\text { eles residentes, sejam auxiliares de enfermagem ou } \\
\text { estagiário de qualquer categoria, que passem por esta } \\
\text { explanação de motivos pelos quais a gente quer, para } \\
\text { que isso seja humanizado. Ainda falta muito, por } \\
\text { parte de todos os profissionais. As pessoas necessitam } \\
\text { ter humanidade dentro de si, bom senso e muito amor } \\
\text { ao próximo. Respeito, profissionalismo e e } \\
\text { conhecimento técnico cientifico. É quando você deixa } \\
\text { de fazer o que você tem que fazer, quando você deixa } \\
\text { para que o outro faça, passa a não ligar. } \\
\text { Sujeitos: (E5, E2, E3, E4) }\end{array}$ & $\begin{array}{l}\text { Gostariamos que as pacientes da } \\
\text { SEMI-INTENSIVA, tivessem um } \\
\text { acompanhamento mais preciso, } \\
\text { para que elas não fiquem tão } \\
\text { ansiosas e tanto tempo } \\
\text { hospitalizadas, pois elas ficam } \\
\text { bastante depressivas, embora } \\
\text { estamos aqui para dar todo apoio } \\
\text { a elas Aproveitando a } \\
\text { oportunidade, para que as } \\
\text { enfermeiras tenham autonomia } \\
\text { quanto aos auxiliares e equipe em } \\
\text { seus setores. }\end{array}$ \\
\hline
\end{tabular}

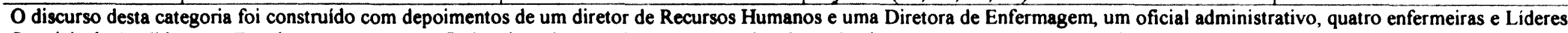
Setoriais de Acolhimento. Em alguns setores os profissionais embora projetem a pespectiva de equipe integração encontram-se em situaçðes de agrupamento 


\section{DISCIIRSO DO SUJEITO COIEIIVO}

\section{Cite itens de desumanização neste hospital.}

\begin{tabular}{|c|c|c|}
\hline $\begin{array}{c}I D E I A \\
C E N T R A L C\end{array}$ & Direçåo do HMI e A mbulatório & Líderes Setoriais de Acolhimento \\
\hline $\begin{array}{c}\text { A área de } \\
\text { humanização } \\
\text { não } \\
\text { acompanha a } \\
\text { área técnica } \\
\text { que no HMI é } \\
\text { de primeira } \\
\text { qualidade }\end{array}$ & $\begin{array}{l}\text { Nós temos dentro da Maternidade uma coisa muito importante, nós temos um atendimento técnico } \\
\text { de primeira qualidade, mas o atendimento humano ainda não acompanha o nosso atendimento } \\
\text { técnico. A gente tem que incrementar açães nesta área de humanização, e isso é uma parte que } \\
\text { ainda não me dá satisfação total dentro desta entidade. A gente tem dentro da Maternidade algumas } \\
\text { coisas, não digo que sejam completamente desumanas, mas algum atendimento que ainda merece } \\
\text { um pouquinho mais de trato. Vai desde a parte médica, que o médico as vezes ele acha que sabe } \\
\text { tudo. A parte técnica a gente não discute, mas na parte da humanização a área médica talvez seja o } \\
\text { setor que por incrivel que pareça, que está mais atrasado no item humanização. Mas, isso tudo é } \\
\text { compensado às vezes na parte técnica. É um bom médico, um bom cirurgiåo, mas o trato, o lidar } \\
\text { com a paciente, neste caso deixa a desejar. Nós temos carência na parte médica, nós temos carência } \\
\text { na parte de recepça,o, nós temos carência também na parte de enfermagem. Cada setor tem a sua } \\
\text { peculiaridade e cada setor está deficiente em alguma coisa. A gente tenta incrementar ações nessa } \\
\text { área. A parte médica para mim, ainda é a parte mais resistente no processo de humanização. } \\
\text { Sujeitos: (DG) }\end{array}$ & $\begin{array}{l}\text { A mudança tem que vir do superior, acho que a diretoria, os } \\
\text { médicos têm que ser mais humanos, porque a maioria das } \\
\text { vezes que ocorre problemas com a gente, com o atendimento, } \\
\text { os culpados são os médicos, porque eles são desumanos, não } \\
\text { se colocam no lugar da pessoa em nenhum instante e o parto } \\
\text { normal acaba saindo anormal. Acho que também o noturno } \\
\text { deveria ter as normas, porque aqui neste hospital a diretoria só } \\
\text { funciona de dia (diurno). A noite é completamente diferente. } \\
\text { Tam,bem acho que a diretoria deveria sensibilizar e se colocar } \\
\text { no lugar de quem fica } 12 \text { horas sem lanche da tarde. A } \\
\text { enfermagem precisa ter mais acolhimento e interação com a } \\
\text { recepção. Dar maior atenção aos funcionários noturnos e as } \\
\text { adolescentes em geral, mesmo as que não fazem Pré-Natal } \\
\text { aqui. }\end{array}$ \\
\hline
\end{tabular}

\begin{tabular}{|c|c|c|c|}
\hline $\begin{array}{c}\text { IDEIA } \\
\text { CENTRALD }\end{array}$ & $\begin{array}{c}\text { Profissionais da Área } \\
\text { Administrativa }\end{array}$ & Outros profissionais da área Assistencial & $\begin{array}{l}\text { Lideres Setoriais } \\
\text { de Acolhimento }\end{array}$ \\
\hline $\begin{array}{l}\text { A lógica atual da } \\
\text { residência médica na } \\
\text { grande maioria dos } \\
\text { locais, propicia/ estimula } \\
\text { o excesso de intervenção } \\
\text { em nome do aprendizado }\end{array}$ & & $\begin{array}{l}\text { Eu gostaria que estivesse uma humanização do parto que nós não temos ainda, mas nós vamos } \\
\text { ter. Nós estamos com uma carência de funcionários muito grande. Pelo fato de nós termos } \\
\text { residência médica aqui, as mães são muito mal tratadas, manuseadas, às vezes são até muito } \\
\text { induzida, as vezes até se força um fórcipes, eu acho que isso é normal, eles tem que aprender, } \\
\text { Mas forçar um fórcipe desnecessário não da. No Pré-Parto e no Centro Obstétrico que eu } \\
\text { encontro mais pontos de desumanizaçảo, mas depois que ela desce a situação se normaliza } \\
\text { novamente. Sujeitos: (E2) }\end{array}$ & \\
\hline
\end{tabular}

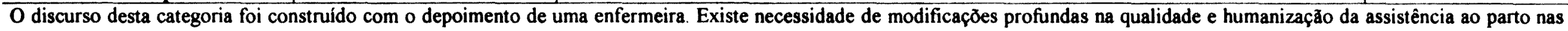
maternidades brasileiras. 


\section{DISCURSO DO SUJEITO COLETIVO}

\section{Cite itens de desumanização neste hospital.}

\begin{tabular}{|c|c|c|c|}
\hline $\begin{array}{c}\text { IDEIA } \\
\text { CENTRALE }\end{array}$ & Profissionais da Área Administrativa & $\begin{array}{l}\text { Outros Profissionais } \\
\text { da Área Assistencial }\end{array}$ & $\begin{array}{c}\text { Lideres Setoriais de } \\
\text { Acolhimento }\end{array}$ \\
\hline $\begin{array}{l}\text { O ponto fraco do IIMI é a } \\
\text { recepção pois não acolhe a } \\
\text { paciente emocionalmente } \\
\text { descompensada }\end{array}$ & $\begin{array}{l}\text { A recep̧ăo para mim eu acho que poderia ser melhor. Tem recepcionistas aqui do } \\
\text { hospital que poderiam tratar melhor quem vem de fora, por exemplo, se a pessoa vem } \\
\text { nervosa tentar tranqüilizar e não colocar mais lenha na fogueira, acho que aqui o que } \\
\text { falha, o ponto fraco daqui do hospital é a recepção. Eu acredito que seja as } \\
\text { recepcionistas, a entrada para mim, está tendo um bloqueio muito grande, está tendo } \\
\text { uma falha, que se tentar humanizar primeiro as recepcionistas, tudo vai fluir, mas do } \\
\text { jeito que está eu acho que o bloqueio está ai. } \\
\text { Sujeitos: (OA3, OA4) }\end{array}$ & & \\
\hline
\end{tabular}




\section{DISCURSO DO SUJEITO COLETIVO}

\section{A estrutura fisica deste hospital atrapalha o processo de humanização da assistência?}

\begin{tabular}{|c|c|c|}
\hline $\begin{array}{c}\text { IDEIA } \\
\text { CENTRALA } \\
\end{array}$ & $\begin{array}{c}\text { Direçåo do HMI e } \\
\text { Ambulatório }\end{array}$ & Outros Profissionais da Área Assistencial \\
\hline $\begin{array}{c}\text { A estrutura } \\
\text { física dificulta } \\
\text { mas não } \\
\text { impede o } \\
\text { processo de } \\
\text { Humanização } \\
\text { da Assistência }\end{array}$ & $\begin{array}{l}\text { A gente não tem estrutura } \\
\text { fisica grande o suficiente } \\
\text { para esta- fazendo o trabalho } \\
\text { de humanização do jeito que } \\
\text { nós queremos, mas isso não } \\
\text { impede. Atrapalha em termos } \\
\text { de espaço fisico. O nosso } \\
\text { maior sonho é fazer o pré- } \\
\text { parto, o parto humanizado, só } \\
\text { que a estrutura física do local } \\
\text { impede você estar colocando } \\
\text { o pai ou o acompanhante lá } \\
\text { dentro. Então, assim dá para } \\
\text { se fazer? Dá, mas é um } \\
\text { espaço muito pequeno. Às } \\
\text { vezes acaba atrapalhando o } \\
\text { profissional que está lá e a } \\
\text { familia não fica tão a a } \\
\text { vontade. Ao meu ponto de } \\
\text { vista se fosse um local que } \\
\text { tivesse uma estrutura fisica } \\
\text { maior, mais abrangente eu } \\
\text { acho que seria maravilhoso. } \\
\text { Sujeitos: (DE) }\end{array}$ & 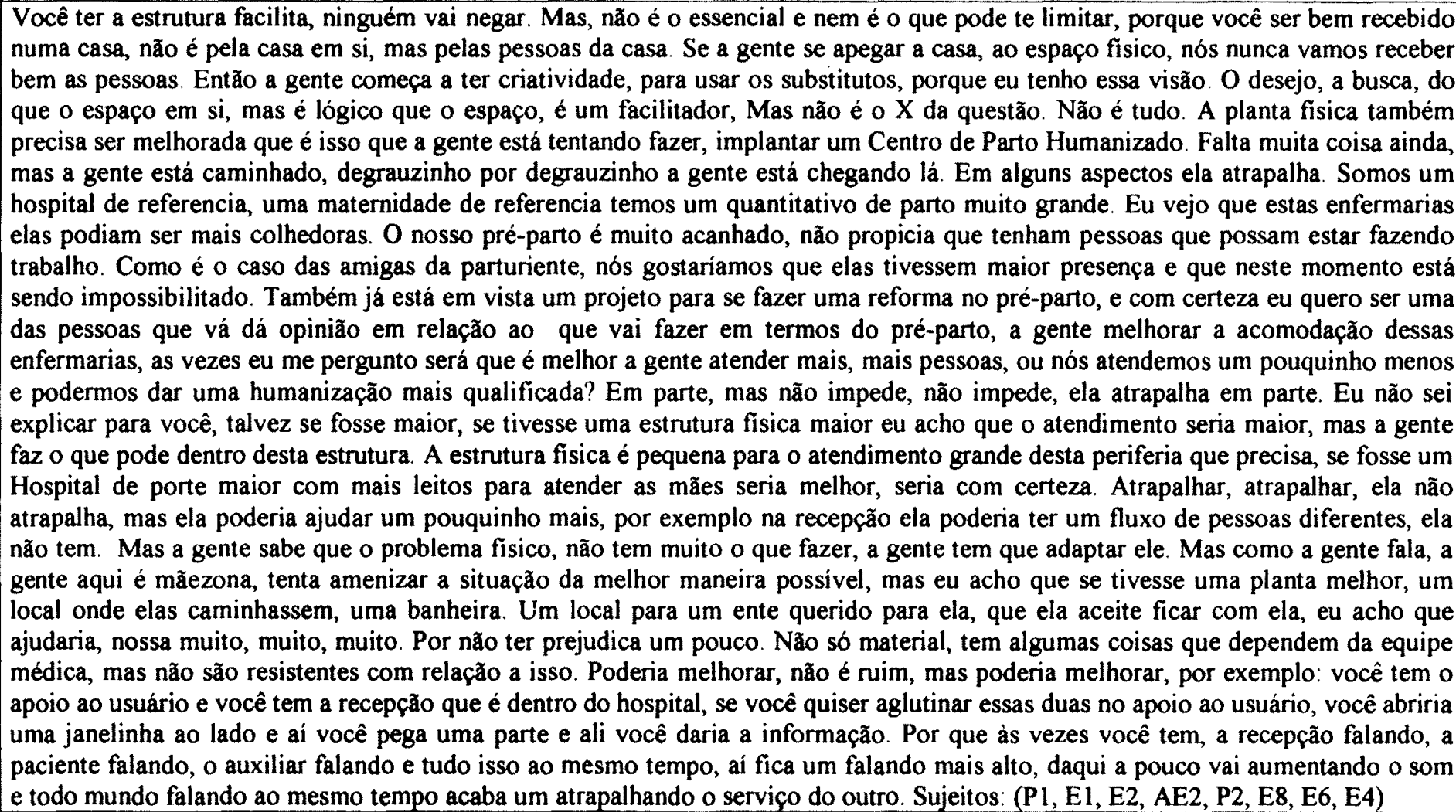 \\
\hline \multicolumn{3}{|c|}{ 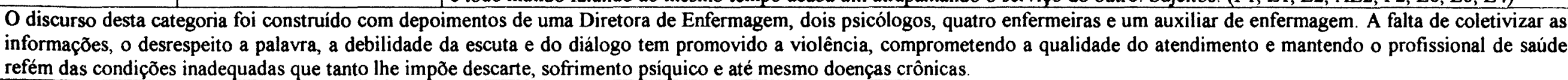 } \\
\hline
\end{tabular}




\section{DISCURSO DO SUJEITO COLETIVO}

A estrutura fisica deste hospital atrapalha o processo de humanização da assistência?

\begin{tabular}{|c|c|c|c|}
\hline $\begin{array}{c}\text { IDÉ IA } \\
\text { CENTRALB }\end{array}$ & Profissionais da Área Administrativa & $\begin{array}{l}\text { Outros Profissionais } \\
\text { da Área Assistencial }\end{array}$ & $\begin{array}{l}\text { Lideres Setoriais } \\
\text { de Acolhimento }\end{array}$ \\
\hline $\begin{array}{c}\text { A humanização da } \\
\text { assistência depende mais } \\
\text { dos Funcionários do que } \\
\text { da estrutura física da } \\
\text { instituição }\end{array}$ & $\begin{array}{l}\text { Não. Aqui é igual coração de mãe, sempre cabe mais um. A estrutura fisica? Acho que não, } \\
\text { porque para haver humanização a gente precisa de sensibilidade, não estrutura fisica, estrutura } \\
\text { humana. Acho que não atrapalha. Acho que soma.Eu acho que não, eu acho que depende mais } \\
\text { dos funcionários em si, do que realmente do espaço, porque eu acho que quando a gente, pode } \\
\text { tratar bem Não, acho que está um bom padrão. Não influência nada. O que influência } \\
\text { primeiramente, é o mal atendimento. Se de repente entra uma mãe, que a gente sabe que o ela } \\
\text { está passando ali, não é făcil. Então as vezes o má atendimento, essas coisas todas. A estrutura } \\
\text { fisica está ótimo, algumas coisas que precisam ser feitas no caso, melhorar a qualidade do } \\
\text { elevador, estas coisas todas, é uma coisa que eu creio que mais para frente a direção do } \\
\text { hospital vai estar agilizando, depende de verba, agora em termos de estrutura fisica está } \\
\text { ótimo. Não atrapalha, inclusive a gente vê aqui quando os médicos, o empenho que eles têm, } \\
\text { a gente não deixa muito superlotar, não tem essa dificuldade. Sujeitos: (S2,OA1, OA2,S4) }\end{array}$ & & \\
\hline \multicolumn{4}{|c|}{ 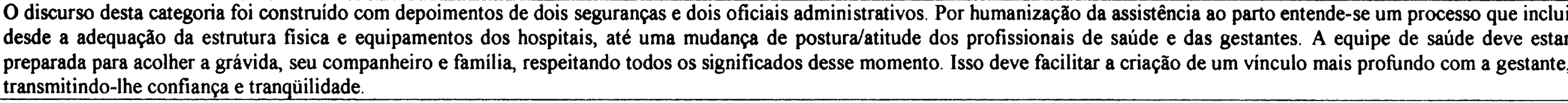 } \\
\hline
\end{tabular}




\section{DISCIRSO DO SUJEITO COI.EIIVO}

\section{Qual o profissional que tem maior resistência ao processo de humanização da assistência?}

\begin{tabular}{|c|c|c|}
\hline $\begin{array}{c}\text { IDEIA } \\
\text { CENTRALA }\end{array}$ & $\begin{array}{c}\text { Médicos (Obstetras, Residentes, Neonatologistas, Anestesiologistas, UTI Materno } \\
\text { e Neonatal) }\end{array}$ & Direção do HMI e A mbulatório \\
\hline $\begin{array}{c}\text { O processo de } \\
\text { humanização da } \\
\text { assistência } \\
\text { independe da } \\
\text { especialidade } \\
\text { e/ou profissão } \\
\text { do profissional, } \\
\text { mas sim o seu } \\
\text { comportamento }\end{array}$ & $\begin{array}{l}\text { Eu acho que qualquer profissional pode atrapalhar, esse processo, e qualquer profissional pode ajudar, o } \\
\text { profissional que tem contato direto com a mãe. Principalmente no trabalho de parto. Depende da } \\
\text { atuação profissional, da conscientização que ele tem no trabalho dele, se ele é um profissional } \\
\text { consciente, que trabalhe sério, ele vai está somando para a humanizaçăo, o trabalho de parto. Se ele não } \\
\text { for um profissional tão consciente assim, isso vai ser só mais um detalhe, sem importância em todos os } \\
\text { aspectos do hospital, vão ser motivos suficientes para ele não dispensar uma atenção de humanização } \\
\text { para mãe. Então, eu acho que depende de cada um, isso cada um pode ser, ou um profissional que preza } \\
\text { pela humanização ou que não. O fato de atrapalhar ou facilitar a humanização da assistência não } \\
\text { depende de nenhuma categoria especifica, mas da formação, do perfil do profissional de saúde. Eu } \\
\text { conheço neonatologistas que aqui tem fama de ser humanizados, que quando ele aparece na sala de } \\
\text { parto ele desumaniza o parto. Só dá palpite errado. Não, depende que exista um acordo entre os } \\
\text { ginecologistas e os neonatologistas, eu acho que tem tudo para dar certo, ambos tem que falar a mesma } \\
\text { língua,. Não pode eu tomar uma postura desumanizada e GO a postura humanizada, dá tudo errado o } \\
\text { parto. Os dois tem que seguir a mesma postura, e aí dá certo. Eu acho que qualquer profissional pode } \\
\text { atrapalhar, esse processo, e qualquer profissional pode ajudar, o profissional que tem contato direto com } \\
\text { a mãe. Principalmente no trabalho de parto. Depende da atuação profissional, da conscientização que } \\
\text { ele tem no trabalho dele, se ele é um profissional consciente, que trabalhe sério, ele vai está somando } \\
\text { para a humanização, o trabalho de parto. Se ele não for um profissional tão consciente assim, isso vai } \\
\text { ser só mais um detalhe, sem importância em todos os aspectos do hospital, vão ser motivos suficientes } \\
\text { para ele não dispensar uma atenção de humanização para mãe. Então, eu acho que depende de cada um, } \\
\text { isso cada um pode ser, ou um profissional que preza pela humanização ou que não. } \\
\text { Sujeitos: (RB, O6, Nl) }\end{array}$ & $\begin{array}{l}\text { Não existe nominação, todos ajudam ou todos atrapalha. } \\
\text { Esta relacionado a pessoa e não a profissional. É o que } \\
\text { eu falei no começo, quem colabora e quem realmente } \\
\text { exerce os processos de humanização ou não são pessoas } \\
\text { que estão nesse na instituição, a instituição tem o limite } \\
\text { do que você pode fazer, agora ultrapassou o limite de } \\
\text { instituição é de cada um, depende da sensibilização que } \\
\text { cada um vai ter sobre a atividade. O profissional que } \\
\text { mais atrapalha no processo de humanização é aquele } \\
\text { que não entende a importância da humanização na } \\
\text { assistência materno-neonatal. Ele pode ser, desde o } \\
\text { médico até o porteiro. Se ele não percebe que isso faz } \\
\text { diferença ele atrapalha toda a equipe. Não o profissional } \\
\text { eu acho que é a pessoa, porque querendo ou não os } \\
\text { profissionais em si, profissão é uma profissão a toa, } \\
\text { porque as vezes pode ser um faxineiro que colabore e } \\
\text { isso não quer dizer nada. Então eu acho que é a pessoa e } \\
\text { não o profissional. } \\
\text { Sujeitos: (DC, DU, DE) }\end{array}$ \\
\hline \multicolumn{3}{|c|}{ 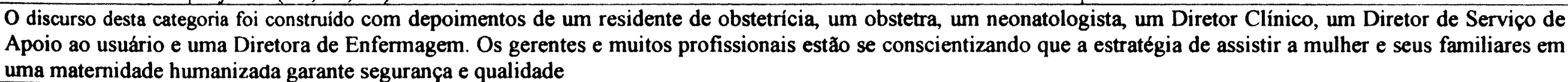 } \\
\hline
\end{tabular}




\section{DISCURSO DO SUJEITO COLETIVO}

\section{Qual o profissional que tem maior resistência ao processo de humanização da assistência?}

\begin{tabular}{|c|c|c|}
\hline $\begin{array}{c}\text { IDEIA } \\
\text { CENTRALB }\end{array}$ & Médicos (Obstetras, Residentes, Neonatologistas, Anestesiologistas, UTI Materno e Neonatal) & $\begin{array}{l}\text { Direção do HMI } \\
\text { e Ambulatório }\end{array}$ \\
\hline $\begin{array}{c}\text { O médico é o } \\
\text { profissional } \\
\text { que mais } \\
\text { dificulta o } \\
\text { processo de } \\
\text { Humanização } \\
\text { da Assistência }\end{array}$ & 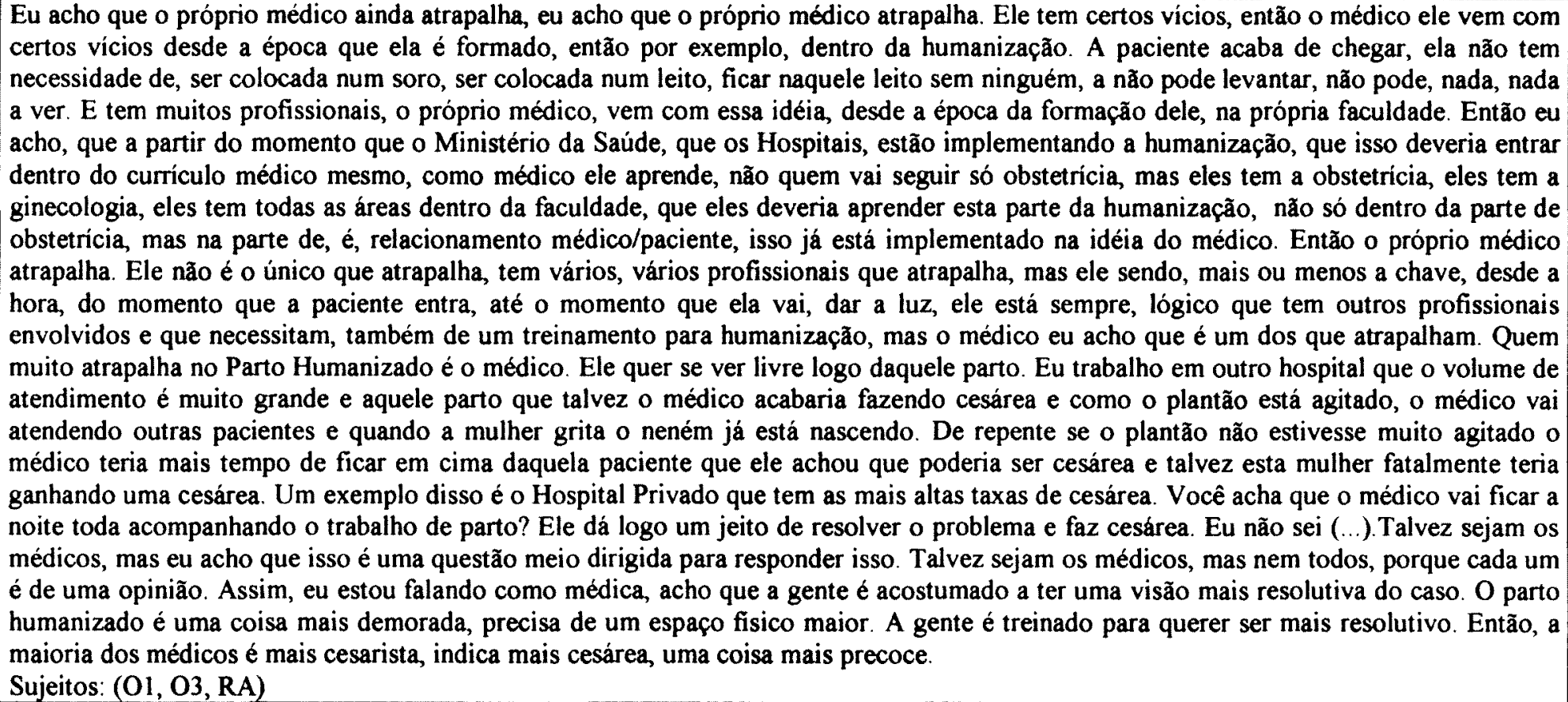 & $\begin{array}{l}\text { Não é que atrapalha, } \\
\text { ele tem mais } \\
\text { resistência a cooperar. } \\
\text { Ele não chega a } \\
\text { atrapalhar, mas } \\
\text { normalmente ele a } \\
\text { mais resistente a } \\
\text { cooperar. O médico } \\
\text { normalmente a esses } \\
\text { tipos de ações eles são } \\
\text { meio resistentes. } \\
\text { Sujeitos: (DG) }\end{array}$ \\
\hline
\end{tabular}

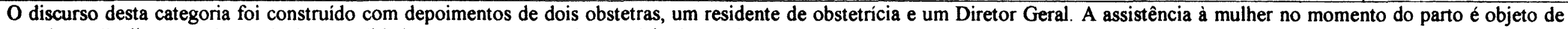

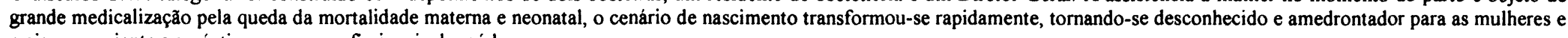
mais conveniente e asséptico para os profissionais de saúde. 


\section{DISCURSO DO SUJEITO COLETIVO}

\section{Qual o profissional que tem maior resistência ao processo de humanização da assistência?}

\begin{tabular}{|c|c|c|}
\hline $\begin{array}{c}\text { IDEIA } \\
\text { CENTR ILC }\end{array}$ & $\begin{array}{l}\text { Profissionais da área } \\
\text { Administrativa }\end{array}$ & Outros profissionais da área Assistencial \\
\hline $\begin{array}{l}\text { O médico é o } \\
\text { profissional } \\
\text { que mais } \\
\text { dificulta o } \\
\text { processo de } \\
\text { Humanização } \\
\text { da Assistência }\end{array}$ & & $\begin{array}{l}\text { Na verdade, eu acho que aqui no caso alguns médicos realmente são bem desumanos, nem olham no olho do paciente. Não pode } \\
\text { deixar o usuário perambulando por ai e as vezes ele acaba indo para qualquer lado, são esses profissionais talvez, que poderiam } \\
\text { melhorar um pouquinho. Olha pela formação é o médico que atrapalha mais, porque ele vem com uma formação muito, ah, muito, } \\
\text { muito forte com aquela coisa de maior poder. Então isso, e pela cultura, a formação que ele teve também. Então muito me alegrou na } \\
\text { tese, na dissertação de mestrado de uma colega nossa, que o orientador médico pela primeira vez tinha orientado uma enfermeira e } \\
\text { que ele a convidou para, para dar aula para os médicos das universidades, para eles entenderem o que é humanização, como se deve } \\
\text { pensar, o que, como se deve tratar uma mulher, uma parturiente. Mas assim, eu acho que quando complica eu acho que o médico } \\
\text { que tem que intervir logo, então, a gente fica numa situação mais estressante do que uma enfermeira obstetriz, ou de uma auxiliar, ou } \\
\text { de que uma Doula, assim, no caso de vocês que estão fazendo este negócio de parto humanizado. O médico é sempre a parte aonde } \\
\text { vai estourar as coisas. Entåo, ele tem uma visão mais voltada para catástrofe. Mas, eu não acho que ele atrapalhe, eu acho que se ele } \\
\text { for bem treinado, bem orientado e tal, eu acho que ele seria o que mais facilitaria, porque, ao mesmo tempo que ele é o maior } \\
\text { entrave de vocês, ele seria o maior facilitador, também se for bem treinado, bem orientado e se tiver um espaço fisico adequado e se } \\
\text { demonstrarem que isso dai vai ser uma coisa boa, Depende, tem alguns Go, e tem alguns neonatologistas, ou seja, não são a favor da } \\
\text { humanização, então não tem aquela visão, é desorientado, o outro já acha que a humanização é, "o parto humanizado, esse parto de } \\
\text { cócoras, esse parto de ficar dando banho, e isso ai! Então, é complicado. Eu acho que os médicos, alguns por não aderirem a isso, é, } \\
\text { prejudica. Sujeitos: (P2, E2, F1) }\end{array}$ \\
\hline
\end{tabular}




\section{DISCURSO DO SUJEITO COLETIVO}

\section{Qual o profissional que tem maior resistência ao processo de humanização da assistência?}

\begin{tabular}{|c|c|c|c|}
\hline $\begin{array}{c}\text { IDÉIA } \\
\text { CENTRAL D }\end{array}$ & $\begin{array}{c}\text { Prof. área } \\
\text { Administrativa }\end{array}$ & Outros profissionais da área Assistencial & $\begin{array}{c}\text { Líderes } \\
\text { Setoriais de } \\
\text { Acolhimento }\end{array}$ \\
\hline $\begin{array}{l}\text { O residente de obstetrícia é o profissional } \\
\text { que mais dificulta o processo de } \\
\text { humanização da assistência, pois no intuito } \\
\text { de aprender acabam manuseando muito as } \\
\text { pacientes }\end{array}$ & & $\begin{array}{l}\text { Eu acho que é o residente. Como eles estão no intuito de aprender, eles } \\
\text { manuseiam muito as pacientes, eles tocam desnecessariamente, eles fazem um } \\
\text { fórcipe às vezes desnecessariamente. Não que eles estejam errados, porque } \\
\text { eles têm que aprender, mas fazem muitos procedimentos desnecessários. } \\
\text { Sujeitos: (E1) }\end{array}$ & \\
\hline
\end{tabular}




\section{DISCURSO DO SUJEITO COI E'TIVO}

\section{Qual o profissional que mais colabora com o processo de humanização da assistência?}

\begin{tabular}{|c|c|c|c|}
\hline $\begin{array}{c}\text { IDEIA } \\
\text { CENTRALA }\end{array}$ & $\begin{array}{l}\text { Médicos (Obstetras, Residentes, Neonatologistas, } \\
\text { Anestesiologistas, UTI Materno e Neonatal) }\end{array}$ & Direção do HMI e Ambulatório & $\begin{array}{l}\text { Profissionais da área } \\
\text { Administrativa }\end{array}$ \\
\hline $\begin{array}{l}\text { A Auxiliar de } \\
\text { Enfermagem é } \\
\text { a profissional } \\
\text { que mais } \\
\text { colabora no } \\
\text { processo de } \\
\text { Humanização } \\
\text { da Assistência }\end{array}$ & $\begin{array}{l}\text { A Diretoria tenta incentivar bastante o parto humanizado, mas } \\
\text { infelizmente o espaço fisico pega muito aqui (...). O Auxiliar de } \\
\text { Enfermagem colabora e as voluntárias também. Só que atualmente elas } \\
\text { não estão entrando mais e atuando como Doulas, dificultaram a entrada } \\
\text { delas porque o espaço fisico do pré-parto é muito pequeno e depois } \\
\text { chegaram os Residentes, parte dos auxiliares de enfermagem. Porque eu } \\
\text { vejo que eles tem um carinho, eles (aux. de enfermagem) que trocam a } \\
\text { paciente, eles vão conversando, eles vão explicando o que vai fazer, } \\
\text { para onde agora elas vão, eles que levam em todo o trajeto. Olha eu não } \\
\text { posso falar em um termo geral, eu fico muito aqui em baixo, mas o } \\
\text { pouco tempo que eu vejo os auxiliares de enfermagem são muito mais } \\
\text { humanizados. e modo geral, os profissionais da enfermagem são bem } \\
\text { mais acolhedores que os médicos. Eles são mais tolerantes e sensiveis } \\
\text { (...). Eu acho que os auxiliares, assim, porque eles que ficam mais no } \\
\text { pré-parto. O auxiliar mesmo. A obstetriz, fica mais de dia, a noite não } \\
\text { tem obstetriz. Então, eu acho que quem fica mais controlando mesmo, } \\
\text { são os residentes. No caso que é a gente que fica em cima bastante, mas } \\
\text { as vezes você entra em uma cesárea, entra em um procedimento mais } \\
\text { demorado, você não fica lá toda hora e ela está com sede, ela pede para } \\
\text { o auxiliar. Então, eu acho que é o auxiliar de enfermagem, o residente } \\
\text { quando tem hospital com residente. O residente tem mais condiçðes de } \\
\text { ficar mais próximo e dar uma acolhida melhor. A obstetriz, eu acho que } \\
\text { é a equipe como um todo, mas eu acho que quem fica mais assim, é o } \\
\text { auxiliar de enfermagem, porque está mais próximo e todo o tempo do } \\
\text { processo. } \\
\text { Sujeitos: (O3, O5, O6, RA) }\end{array}$ & $\begin{array}{l}\text { O profissional mais simples, normalmente ele parece que ele } \\
\text { está mais, ele vivencia mais o processo de humanização, } \\
\text { certo? Talvez, ele está mais, aquele profissional que está } \\
\text { sempre mais perto da mãe é o auxiliar de enfermagem, eu } \\
\text { acho que é a pessoa mais sensibilizada para este processo. O } \\
\text { que colaboram mais com as pessoas, o número maior são os } \\
\text { auxiliares de enfermagem, mas ao meu ponto de vista. As } \\
\text { enfermeiras, é complicado, tem umas que são humanas, tem } \\
\text { outras que não estão nem ai. Os auxiliares de enfermagem a } \\
\text { maioria são humanos. As enfermeiras elas até são, só que } \\
\text { assim é tanta burocracia no papel que elas se perdem no } \\
\text { papel e não tem tempo para paciente. Hoje eu estou quase } \\
\text { louca, você não tem noção eu to quase louca. O que mais } \\
\text { colabora é o pessoal da porta de entrada. Os meu auxiliares } \\
\text { do Pronto Socorro eu acho que são as pessoas que mais } \\
\text { fazem o papel de humanização. Ultimamente os auxiliares } \\
\text { estão mais acolhidos ao contrário de anos anteriores. Desde } \\
\text { quando eu vim para cá para Maternidade, já tem quatro anos } \\
\text { que eu estou na Maternidade, mas eu estava no ambulatório } \\
\text { e tem um ano e meio que estou aqui, eu acho que melhorou } \\
\text { bastante perto daquilo que era antes. Só que ainda falta } \\
\text { muito e é complicado porque você mexer com a estrutura } \\
\text { emocional de funcionário, você mexer com crenças de } \\
\text { funcionários é complicado. } \\
\text { Sujeitos: (DG, DE) }\end{array}$ & $\begin{array}{l}\text { Os auxiliares, os auxiliares } \\
\text { estão o tempo todo, desde } \\
\text { a entrada, da pessoa aqui } \\
\text { na portaria do PS. Todo } \\
\text { processo até a saida, é o } \\
\text { contato direto apropriado. } \\
\text { Sujeitos: (S2) }\end{array}$ \\
\hline
\end{tabular}




\section{DISCURSO DO SUJEITO COLE'TIVO}

\section{Qual o profissional que mais colabora com o processo de humanização da assistência?}

\begin{tabular}{|c|c|c|}
\hline $\begin{array}{c}\text { IDEIA } \\
\text { CENTRALB }\end{array}$ & \begin{tabular}{|c|} 
Médicos (Obstetras, Residentes, Neonatologistas, \\
Anestesiologistas, UTI Materno e Neonatal)
\end{tabular} & Outros Profissionais da Área Assistencial \\
\hline $\begin{array}{c}\text { A obstetriz é a } \\
\text { profissional } \\
\text { que mais } \\
\text { colabora no } \\
\text { processo de } \\
\text { humanização }\end{array}$ & $\begin{array}{l}\text { Eu acho que a enfermeira obstetriz quando bem orientada é } \\
\text { uma que, eu acho que por ser mulher, vai acompanhar melhor } \\
\text { a paciente e é a que tem a maior facilidade ali com ela, durante } \\
\text { o trabalho de parto ela que está sempre mais do lado. As vezes } \\
\text { até mais que o médico. enfermeira obstétrica se ela tiver perfil } \\
\text { e for bem treinada, ela evita muitas intervenções } \\
\text { desnecessárias (...). Aqueles que tem mais contato com o } \\
\text { paciente, eu acho que são os que conseguem exercitar isso } \\
\text { melhor, então eu acho que a equipe de enfermagem, a obstetriz } \\
\text { é a que acaba conseguindo exercitar mais a humanização, } \\
\text { porque ela tem mais proximidade com o paciente. } \\
\text { Sujeitos: (RD, O6, N2) }\end{array}$ & $\begin{array}{l}\text { Eu vejo que é a enfermagem, a enfermagem ela colabora mais. Olha eu acredito que até pela } \\
\text { própria formação nossa de cuidar. Então você está cuidando você quer ver que aquilo, que aquele } \\
\text { procedimento que você vai fazer possa até ser doloroso, alguma coisa assim, mas é pro bem-estar } \\
\text { da paciente, naquele momento que você está nesse processo do cuidar você ao mesmo tempo, está } \\
\text { falando, você está conversando, muitas vezes ela te conta a vida dela, você pode dar um apoio. } \\
\text { Então eu acho que é muito essa coisa do apoio, porque na realidade você nota assim, que é em } \\
\text { ultimo caso que elas chamam o médico, a primeira palavra que vem na boca sempre é a } \\
\text { enfermeira, chama a enfermeira. Eu acho que são as enfermeiras. Eu acho assim, por já ter uma } \\
\text { mentalidade assim, de ajudar o próximo, de trabalhar mais o lado emocional da mulher, de estar } \\
\text { mais constante, porque eu acho que o médico só deixa a prescrição, eu acho que já, a enfermagem, } \\
\text { a enfermeira, já cuida, já trata, já tenta zelar, já dá um apoio emocional, um apoio em todos os } \\
\text { momentos dificeis do paciente, que muitas vezes a equipe médica não dá. Não tenha dúvida que é } \\
\text { a Obstetriz e as Enfermeiras obstétricas. Na assistência de um modo geral as auxiliares de } \\
\text { enfermagem, principalmente perto da porta, elas são muito humanas, tem auxiliares de } \\
\text { enfermagem que fica segurando na mão da parturiente, ficam conversando. A enfermagem, está } 24 \\
\text { horas com a paciente. O médico vem passa a visita e vai embora e muitas vezes o médico (...), háa } \\
\text { desencontro médico, porque o plantonista vem, amanhã vem outro, depois vem outro de amanhã } \\
\text { vem outro. Então, a enfermagem não, a enfermagem está todo dia, ela está constante, ela está do } \\
\text { lado da paciente. Então, quando a paciente tem alguma coisa para falar é com a enfermagem que } \\
\text { ela fala, porque o médico nem sempre está aqui. Os médicos colaboram muito também, mas a } \\
\text { enfermagem é que está mais tempo com a paciente. } \\
\text { Sujeitos: (E2, E8, E1, E6) }\end{array}$ \\
\hline
\end{tabular}




\section{DISCURSO DO SUJEITO COLETIVO}

\section{Qual o profissional que mais colabora com o processo de humanização da assistência?}

\begin{tabular}{|c|c|c|}
\hline $\begin{array}{c}\text { IDÉIA } \\
\text { CENTRALC }\end{array}$ & $\begin{array}{c}\text { Médicos (Obstetras, Residentes, Neonatologistas, Anestesiologistas, UTI Materno e } \\
\text { Neonatal) }\end{array}$ & $\begin{array}{l}\text { Direção do HMI } \\
\text { e Ambulatório }\end{array}$ \\
\hline $\begin{array}{l}\text { As voluntárias ("A migas da } \\
\text { Parturiente") são as que mais } \\
\text { colaboram no processo de } \\
\text { Humanização da Assistência }\end{array}$ & $\begin{array}{l}\text { Atualmente dentro do hospital, acho que o que mais colabora, atualmente såo as voluntárias. Pelo que eu vejo aqui } \\
\text { dentro, no nosso serviço. Elas passam muita tranquilidade para a mulher. As amigas da parturiente são figuras } \\
\text { indispensáveis nessa maternidade } \\
\text { Sujeitos: }(\mathrm{O} 1, \mathrm{~N} 4, \mathrm{E} 1)\end{array}$ & \\
\hline
\end{tabular}

\section{DISCURSO DO SUJEITO COLETIVO}

\section{Qual o profissional que mais colabora com o processo de humanização da assistência?}

\begin{tabular}{|c|c|c|}
\hline $\begin{array}{c}\text { IDEIA } \\
\text { CENTRAL D }\end{array}$ & $\begin{array}{c}\text { Médicos (Obstetras, Residentes, Neonatologistas, } \\
\text { Anestesiologistas, UTI Materno e Neonatal) }\end{array}$ & Direção do HMI e Ambulatório \\
\hline $\begin{array}{l}\text { O neonatologista é } \\
\text { o profissional que } \\
\text { mais colabora no } \\
\text { processo de } \\
\text { Humanização da } \\
\text { Assistência }\end{array}$ & $\begin{array}{l}\text { Eu vou puxar a sardinha para o meu lado, eu acho que é o neonatologista, } \\
\text { porque é o que eu vejo mais na sala do parto, apesar que eu faço pouco } \\
\text { trabalho de parto aqui, eu sou mais alojamento conjunto. É claro que é o } \\
\text { neonatologista e alguns poucos obstetras que desde há muito tempo tem } \\
\text { lutado pela humanização do parto. Todo neonatologista compreende o bebê, } \\
\text { sabe respeitar a identidade do feto. } \\
\text { Sujeitos: }(\mathrm{N} 1, \mathrm{~N} 3)\end{array}$ & $\begin{array}{l}\text { Eu vejo pela colaboração, em todos os setores tem colaboração, você tem } \\
\text { colaboração na área de obstetrícia, você tem colaboração na área de } \\
\text { neonatologia, você tem ,na área dos anestesistas por incrivel que pareça, certo? } \\
\text { Salvo algumas exceções. Os anestesistas eles participam muito do processo de } \\
\text { humanização. O neonatologista em principio por estar mais vivenciando mais os } \\
\text { problemas da mãe e do recém-nascido, normalmente eles são mais accessíveis a } \\
\text { este tipo de ação, eles colaboram mais } \\
\text { Sujeitos: (DG) }\end{array}$ \\
\hline
\end{tabular}

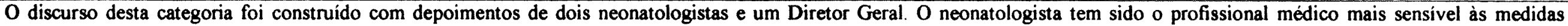

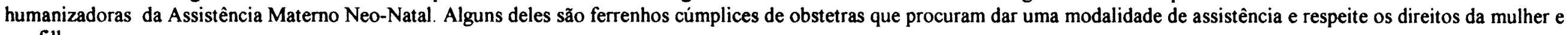
seu filho. 


\section{DISCIRSO DO SUJEITO COLE'TIVO}

\section{Você acha que o Pré-Natal influencia o processo de humanização da assistência?}

\begin{tabular}{|c|c|c|}
\hline $\begin{array}{c}\text { IDEIA } \\
\text { CENTRALA } \\
\end{array}$ & Médicos (Obstetras, Residentes, Neonatologistas, Anestesiologistas, UTI Materno e Neonatal) & $\begin{array}{c}\text { Direção do HMI e } \\
\text { Ambulatório }\end{array}$ \\
\hline $\begin{array}{l}\text { O pré-natal é a } \\
\text { oportunidade do } \\
\text { estabelecimento de } \\
\text { um bom vínculo } \\
\text { entre médico e } \\
\text { paciente }\end{array}$ & $\begin{array}{l}\text { Com certeza. A mãe que é bem acompanhada no pré-natal, tem um pré-natal bem orientado, é bem tratada no pré-natal, ela se sente } \\
\text { acolhida, ela se sente protegida, ela se sente ajudada, ela se sente apoiada. E, nossa ela vai ter um parto muito mais tranqüilo, vai ser } \\
\text { uma mãe que vai está bem orientada no momento do trabalho de parto. Depois em questão do retorno, do puerpério, ela vai retorna } \\
\text { a maternidade. Então, a gente vai ter um acompanhamento com essa mãe, vai ser uma paciente nossa, realmente com uma relação } \\
\text { médico/paciente muito melhor, que vai melhorar muito o trabalho de parto dela e a recuperação pós-parto também. A humanização } \\
\text { do parto começa no pré-natal, não começa ali na sala de pré-parto, ao contrário, aquilo ali é uma consequêêcia de todo o trabalho } \\
\text { que já foi feito, durante os meses de pré-natal. Se o pré-natal é bem orientado, qualquer mãe tem condição de fazer um ótimo } \\
\text { trabalho de parto No pré-natal o profissional tem mais condiçðes de conhecer a mulher não só do ponto de vista obstétrico, mas de } \\
\text { modo holistico. } \\
\text { Sujeitos: }(\mathrm{RB}, \mathrm{O})\end{array}$ & \\
\hline \multicolumn{3}{|c|}{ 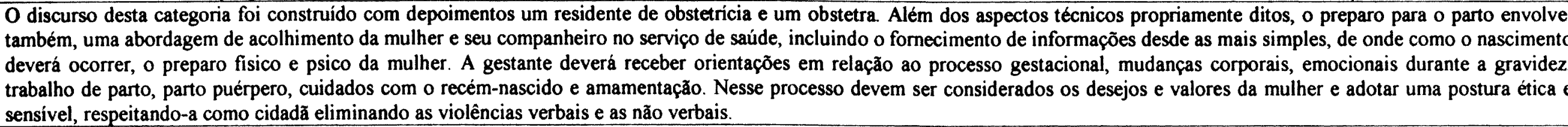 } \\
\hline
\end{tabular}




\section{DISCURSO DO SUJEITO COLETIVO}

\section{Você acha que a história de vida do profissional influencia o processo de humanização da assistência?}

\begin{tabular}{|c|c|c|}
\hline $\begin{array}{c}\text { IDEIA } \\
\text { CENTRALA }\end{array}$ & Médicos (Obstetras, Residentes, Neonatologistas, Anestesiologistas, UTI Materno e Neonatal) & $\begin{array}{c}\text { Direção do HMI } \\
\text { e Ambulatório }\end{array}$ \\
\hline $\begin{array}{c}\text { O profissional } \\
\text { com antecedentes } \\
\text { de maus } \\
\text { resultados } \\
\text { obstétricos na } \\
\text { profissão é mais } \\
\text { intervencionista }\end{array}$ & $\begin{array}{l}\text { Lógico, quando uma pessoa teve uma formação mais intervencionista, quando a pessoa viu muita desgraça, porque a obstetricia é uma } \\
\text { caixa de surpresas. É lindo o parto normal, o parto humanizado é uma teoria maravilhosa, agora eu já vi muitas vezes o parto que era } \\
\text { para ser normal, grandes multíparas que era para dar tudo certo e de repente acontece alguma coisa, que tem que virar uma cesárea de } \\
\text { urgência. Então assim, eu acho que a formação da pessoa ajuda, a personalidade também, às vezes tem gente que acha que já vai dá } \\
\text { mais certo, já é mais otimista, tem gente que já viu tanta coisa que acha que vai dá errado, então já intervir logo, a primeira coisa que } \\
\text { acontece, o partograma não está indo muito bem, ou então outra coisa a pessoa já intervir. Outros tem mais, é a visão, a vivencia pessoal } \\
\text { da pessoa, junto com a formação aonde fez faculdade, aonde fez residência, é um monte de fator junto, a parte emocional, a parte da } \\
\text { personalidade, não tem assim, uma coisa assim um perfil do profissional que seria bom para humanização, eu acho que não existe isso, } \\
\text { eu acho que vai muito haver dá parte de formação acadêmica, mas muito mais da parte da personalidade, ou então as vezes aonde a } \\
\text { gente fez a residência influi bastante, se você viu um lugar que estava o aspecto você acredita mais que dê certo, agora se você viu um } \\
\text { lugar que não era muito, você já não acredita e isso é uma coisa nova. A maior parte das pessoas que teve formação em GO, até agora, } \\
\text { foi uma formação não voltada para isso, agora que está surgindo isso. Eu sei que é antigo, mas a implementação mesmo, pelo Ministério } \\
\text { da Saúde, não faz muito tempo. Então eu acho que tudo isso está relacionado. É claro, eu acho que sim. O profissional que teve uma } \\
\text { experiência muito ruim com humanização, com o parto humanizado, ele vai ter mais ressalvas com o parto humanizado do que o } \\
\text { profissional que só teve boas experiências. } \\
\text { Sujeitos: (RA, N2) }\end{array}$ & \\
\hline
\end{tabular}




\section{DISCURSO DO SUJEITO COLETIVO}

\section{Você acha que a história de vida do profissional influencia o processo de humanização da assistência?}

\begin{tabular}{|c|c|c|c|}
\hline $\begin{array}{c}\text { IDELA } \\
C E N T R A L B\end{array}$ & Profissionais da Area Administrativa & $\begin{array}{l}\text { Outros Profissionais } \\
\text { da Área Assistencial }\end{array}$ & $\begin{array}{l}\text { Lideres Setoriais } \\
\text { de Acolhimento }\end{array}$ \\
\hline $\begin{array}{l}\text { A dificuldade de } \\
\text { certos } \\
\text { profissionais em } \\
\text { lidar com seus } \\
\text { problemas } \\
\text { pessoais têm } \\
\text { comprometido o } \\
\text { acolhimento ao } \\
\text { usuário }\end{array}$ & $\begin{array}{l}\text { Se ele não tiver estrutura psicológica para saber como que funciona a humanização, acho que influência } \\
\text { sim. Precisa ter uma estrutura psicológica. Agora eu acho que a do profissional influência mais, porque } \\
\text { ele vai se doar, a paciente ela vai estar carente, vai estar com dor, com carência de ajuda, a historia da } \\
\text { paciente acho que até não influência tanto, acho que a do profissional influência mais. Sim, porque o } \\
\text { profissional que vem com problema de casa, ele desabafa com certeza na mãezinha, isso a gente vê muito } \\
\text { aqui, acontece muito, então. Isso vem de berço. Eu conheço muitos funcionários aqui que não tem a } \\
\text { mínima, a mínima vocação para lidar com o público, é um fator principal para você poder atender bem. } \\
\text { Porque a pessoa normalmente está aqui, eu acho que mais pela profissão, pelo dinheiro, do que por ajudar } \\
\text { a pessoa. Então, eu acho que isso vem de berço. Se a pessoa não está, interessada em ajudar primeiro a } \\
\text { pessoa e depois o pagamento dela, eu acho que ela não tem a minima condição de fazer um parto } \\
\text { humanizado. Sujeitos: OAl, OA3, OA4) }\end{array}$ & & \\
\hline \multicolumn{4}{|c|}{ 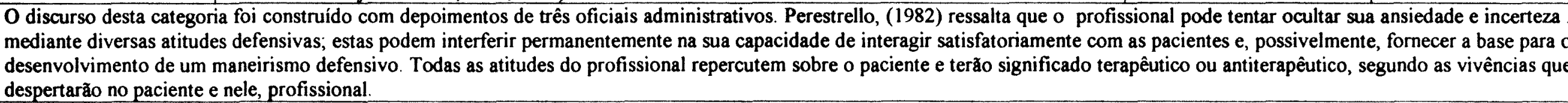 } \\
\hline
\end{tabular}




\section{DISCURSO DO SUJEITO COLETIVO}

\section{Você acha que a história de vida da paciente influencia o processo de humanização da assistência?}

\begin{tabular}{|c|c|c|c|}
\hline $\begin{array}{c}\text { IDEIA } \\
C E N T R A L F\end{array}$ & Profissionais da Área Administrativa & Outros Profissionais da Área Assistencial & $\begin{array}{l}\text { Líderes Setoriais } \\
\text { de Acolhimento }\end{array}$ \\
\hline $\begin{array}{l}\text { Nåo só a história de } \\
\text { vida das pacientes, } \\
\text { mas também as } \\
\text { questões sócio- } \\
\text { econômica-culturais } \\
\text { infuenciam o } \\
\text { processo de } \\
\text { humanização da } \\
\text { assistência }\end{array}$ & $\begin{array}{l}\text { Também, Porque eu acho assim, tem que ver se é, por } \\
\text { exemplo, à gestação foi planejada, ou seja, se ela realmente } \\
\text { ela está feliz com esta, com a gestação, ou seja com a } \\
\text { situação que ela está vivendo em si. Então influência muito, } \\
\text { quer dizer se é uma gravidez desejada, tudo eu creio que vai } \\
\text { correr bem. Se tudo for bem com a mãe, agora se é uma } \\
\text { gravidez que a mãe não desejou, ou seja, aconteceu tal, acho } \\
\text { que influência. Influencia sim, porque eu já peguei muita } \\
\text { paciente aqui que é cabeça dura, que tem medo até de um } \\
\text { dentista quanto mais de um médico obstétrico. Onde } \\
\text { pessoas, maridos de pacientes que não deixava a mulher ter } \\
\text { um exame de toque por puro preconceito. Tem muito marido } \\
\text { de paciente que é muito ignorante, não sabe que o exame de } \\
\text { toque faz parte de todo o procedimento que ela tem que ter e } \\
\text { acha que vai fazer sacanagem com a mulher dele. Eu acho } \\
\text { que até o que influencia muito são os parentes da paciente, } \\
\text { do que a própria paciente. Tem acompanhantes de paciente } \\
\text { que brigam muito com a gente, achando que a gente está } \\
\text { fazendo tudo errado, que a gente está fazendo um processo } \\
\text { lento, mas é de acordo com as possibilidades que o hospital } \\
\text { nos fornece. Eu já peguei acompanhante assim. } \\
\text { Sujeitos: (S4, OA4) }\end{array}$ & $\begin{array}{l}\text { Eu acho que sim. Porque tem muitas pacientes, que a gente, as vezes } \\
\text { elas se abrem com a gente, você vai conversar, você vê, mulher de } \\
\text { bandido, mulher que foi estuprada, mulher que foi estuprada pelo } \\
\text { marido, atrapalha um pouco. Não que atrapalhe ela sempre, ela traz com } \\
\text { ela. Então as vezes, a gente, tem paciente que está mal, você vai } \\
\text { conversar, ai ela começa a contar um pouco da vida dela, que é dureza, } \\
\text { as vezes passa fome. Não tem nem onde morar direito. As vezes é um } \\
\text { filho que os pais não aceitam a criança, filho que é rejeitado pelo } \\
\text { marido, pelo namorado. A história de vida da mulher também } \\
\text { influencia, porque se ela foi criada com outros hábitos culturais, então } \\
\text { colocamos assim, uma indigena que vem para uma maternidade, não } \\
\text { vai dar certo, não vai dar certo, porque? Porque ela tem hábitos culturais } \\
\text { diferenciados. Inclusive tem algumas religiões, algumas culturas que } \\
\text { quando a mulher vai dar a luz, a familia inteirinha tem que ficar do lado. } \\
\text { Isso eu assisti muito porque meu pai tinha uma clientela diferente e era } \\
\text { assim a cultura, todos estavam na hora do parto, a familia inteirinha, se } \\
\text { tinha S0 componentes, tava todo mundo na maternidade esperando o } \\
\text { nascimento daquela criança. E ali no quarto que a gente tinha que pedir } \\
\text { para as pessoas saírem, para mulher não ficar estressada, mas a cultura é } \\
\text { que obrigava a mulher a fazer aquilo. } \\
\text { Sujeitos: (E7, E2) }\end{array}$ & \\
\hline
\end{tabular}


Frente a programas que primam pela melhoria da qualidade do atendimento ao paciente, produto final de um hospital. tais como os programas propostos pelo Ministério da Saúde (MINISTÉRIO DA SAÚDE. 2001 A: Parto, B 2001). fez-se necessário desencadear processos de mudança que apontassem para o fato de que a satisfação de seus clientes externos passasse antes de mais nada, pela satisfação de seus clientes internos, que nada mais são do que seus colaboradores.

O termo "humanização" tem sido empregado constantemente na assistência à saúde. É a base de um amplo conjunto de iniciativas, geralmente designando a forma de assistência que valoriza a qualidade do cuidado do ponto de vista técnico, associada ao reconhecimento dos direitos do paciente, de sua subjetividade e cultura, além do reconhecimento do profissional (DESLANDES 2004).

O conceito de "humanização da assistência" tem sido mais direcionado a uma diretriz de trabalho. um movimento de parceria dos profissionais e gestores, com vistas a melhoria da qualidade assistencial. Implica ainda a valorização do cliente interno e do diálogo intra e inter-equipes.

O termo passou a ser mais usado por ocasião da regulamentação do Programa Nacional de Humanização da Assistência Hospitalar (PNHAH) por parte do Ministério da Saúde em maio de 2000, e este assunto é também incluido na pauta da Conferência Nacional de Saúde. realizada em dezembro do mesmo ano. O PNHAH constitui uma politica ministerial bastante singular se comparada a outras do setor. pois se destina a promover uma nova cultura de atendimento à saúde (MINISTÉRIO DA SAÚDE 2000) no Brasil. O objetivo fundamental do PNHAH seria o de aprimorar as relaçòes entre profissionais, entre usuários/profissionais (campo das interações face-a-face) e entre hospital e comunidade (campo das interações sócio-comunitárias). visando a melhoria da qualidade e à eficácia dos serviços prestados por estas instituiçōes (MINISTÉRIO DA SAÚDE 2000). Atualmente o Programa foi substituido por uma perspectiva transversal. constituindo uma política de assistência e nào mais um programa especifico (provisoriamente intitulada "Humaniza SUS").

Certamente depois de grandes investimentos nas conquistas da ciência emerge o dever e a necessidade de reavaliar nossas posturas. e o que em verdade conquistamos. A ninguém parece plausivel que o fenômeno do nascimento seja relegado a desasistência. porém o preço debitado pela super-mecanização parece estar cada dia mais alto. 
Explode no pensamento de certos profissionais da área materno-infantil, apropriando-se do discurso de JONES (2004) uma questão: Pode um fenômeno tão visceralmente feminino como o nascimento ser conduzido por pressupostos filosóficos tão absolutamente masculinos? Da resposta desta questão certamente aparecerão novos posicionamentos, novas visões e uma reavaliação do que realmente foi conquistado até o momento.

Existem muitos novos profissionais no mercado que pretendem ter uma visão mais abrangente e respeitosa do nascimento. Listas na Internet (Amigas do Parto. Doulas) normativas da OMS, etc... gradativamente vai mudando o modo de pensar dos profissionais em direção a uma nova forma de entender o nascimento humano e suas repercussões sociais. Livros são escritos nesse sentido; artigos publicados, revistas editadas e congressos realizados. Entretanto, nossa realidade pouco se modifica. A crueza do dia-a-dia parece não se afetar por estas iniciativas. Porque, apesar das claras indicaçoes de que uma postura médica mais suave e menos violenta tem resultados melhores, tem prevalecido as altas taxas de intervenção, altos índices de cesariana e conseqüentemente resultados insatisfatórios para a saúde das mães e seus filhos?

Humanização do nascimento lida com a reorganização de um sistema de poder. Não se troca poderes sem ter certeza de que o novo modelo supera o anterior e as evidências têm demonstrado que o atual sistema de atenção a mulher no ciclo gravídico puerperal necessita ser repensado (COCHRANE 2001).

Este estudo considerou ainda dois aspectos diferenciados que precisavam ser associados: tecnologia e a boa administração de relacionamentos. Segundo MERHY (1997). o emprego de tais interações, voltadas para a produção do cuidado. também representa uma forma de tecnologia, a "tecnologia leve" e constitui um elemento crucial de gestão. Justamente nos territórios dessas "tecnologias leves", isto é, que dizem respeito à produção de vínculos. acolhimento. autonomização e de gestão do processo de trabalho. ocorrem atualmente as principais reestruturações produtivas do setor saúde (MERHY 2002). Para o autor. as transições tecnológicas na saúde estão inscritas no modo de atuaça do trabalho vivo em ato e nos processos de gestão do cuidado (MERHY. 2002). Ai se constitui a arena de embate entre modelos médicos neoliberais e aqueles oriundos do movimento sanitário, que defendem um modelo de atençào orientado pela "radical defesa da vida". 
De acordo com DESLANDES (2004), desconsiderar tal debate pode gerar uma atribuição de incompatibilidades. de maior resistência entre os que trabalham com o que há "de objetivo" (tecnologias) e com os que trabalham com o "subjetivo" (relacionamentos), além de ignorar o quão potente são, por exemplo. as tecnologias de escuta e de negociação das regras comportamentais e organizacionais.

Tais ponderações nos fizeram refletir que as interações entre os atores (profissionais e pacientes) são influenciadas por lógicas culturais que as antecedem. Assim, para pensar as (im) possibilidades comunicacionais entre os sujeitos na organização hospitalar antes de tudo foi necessário pensar/ refletir sobre a própria cultura da organização. De acordo com RIVERA (2003), dois aspectos de uma fina dialética foi evidenciado: o da cultura organizacional, como conjunto de referências compartilhadas. que condiciona todo um sistema de regras que vai orientar as formas de gestào e a lógica de ação dos atores. seja a capacidade de os atores influenciarem a mudança das regras, e conseqüentemente a cultura. Em outros termos, se a cultura organizacional se constitui a partir do agir comunicativo dos seus agentes, em processos de aprendizagem e em busca de consenso, suas configurações simbólicas podem ser questionadas em um nivel discursivo (RIVERA 2003).

Entendemos que as possibilidades comunicacionais só se ampliam se toda a cultura de atendimento hospitalar/ ambulatorial caminhar para uma nova modalidade. para "uma nova cultura de atendimento“. Esta só se viabilizaria se for incentivada uma abertura de diálogo. do nível de gestão à organização harmoniosa mais cotidiana do encontro entre gestores, profissionais e usuários. Compartilhamos com RIVERA (2003). que para mudar as regras do jogo organizacional e as bases da cultura é preciso ir além da mudança das "estruturas mentais".

Humanizar a assistência é humanizar a produção desta assistência. 


\section{CONCLUSÕES}

A Pesquisa de Clima Organizacional consistiu em um levantamento de opiniões que caracterizaram a representação da realidade organizacional. retratando o que os funcionários da instituição acreditavam estar acontecendo em um determinado momento. resultando em um diagnóstico sobre a situação atual da organização. Os subsídios fornecidos pela Pesquisa de Clima Organizacional proporcionaram a organização um mapeamento das percepções sobre o ambiente interno da instituição sendo um importante ponto de partida para mudanças $e$ desenvolvimento organizacional.

No desenvolvimento do estudo foi possivel observar que de um modo geral a instituição apresentava sérios comprometimentos em sua cultura organizacional, tais como:

- Deficiência do diálogo - debilidade do processo comunicacional entre profissionais e gestores e entre profissionais e usuários. Impossibilidades da comunicação, presentes no modelo da assistência e nas motivações que mobilizam o cuidado com a paciente;

- As violências simbólica e real que existe na ausência da comunicação;

- Os espaços de "permitir a voz". o acesso à verbalização das demandas dos funcionários eram meramente espaços formais. fictícios:

- Baixa motivação dos funcionários:

- Dicotomia entre tecnologia e fator humano. sobretudo entre os obstetras no tocante a organização da assistência materna;

- Carga excessiva de trabalho, sobretudo os auxiliares de enfermagem:

- Precárias condições de trabalho dos funcionários do SAME (recepcionista) que atuam no Pronto Socorro:

- Equipamentos de trabalho inadequados;

- A não legitimidade da interação profissional-outro (o nào respeito ao outro) no cotidiano das açòes de saúde:

- Ausência de liderança em certos setores de trabalho:

- Os fluxos de trabalho eram muito alienados do resultado final deste trabalho: 
- Os profissionais de saúde desde o segurança até a alta direção não se apropriavam devidamente do seu processo de trabalho e pode-se concluir que este fator contribuia significativamente para desmotivação dos profissionais, sobretudo da área de enfermagem.

As pressões decorrentes da organização do trabalho são fontes significativas de sofrimento. Dentre elas, foi destacado as tensões provenientes do convivio cotidiano com os acompanhantes das pacientes de alto risco gestacional internadas, denunciadora das dificuldades vividas nas relações sociais de trabalho.

$\mathrm{O}$ envelhecimento e adoecimento de parte dos profissionais, sobretudo os auxiliares de enfermagem como um dos principais problemas de saúde pública da instituição é responsável pelo sofrimento cada vez maior de pessoas.

Todavia a ausência de uma lógica contratual por parte da Secretaria de Estado da Saúde que trabalha com duas lógicas contratuais (o funcionário efetivo e o contratado de emergência) e isto repercute na lógica do trabalho da instituição.

O diagnóstico constatado em certos setores foi bem claro: profissionais saudáveis. com menos conflitos e com maior motivação constituíam equipes ativas e mais competentes. Totalmente o inverso do que vinha ocorrendo, sobretudo no UTI neonatal. no Pronto Socorro e no Berçário.

No processo de observação assistemática do trabalho dos profissionais do HMI o fato mais significativo que chamou a atenção da pesquisadora foi o ambiente comum de trabalho na sala de parto. Os profissionais têm considerado este local como qualquer ambiente comum de trabalho, ambiente este em perfeita harmonia com a ética da produçâo industrial. A frieza dos profissionais que participam do nascimento contrastou com a magnitude do evento em si.

Todavia. o diagnóstico de clima organizacional do HMI revelou uma organização com uma cultura forte, porém flexivel para assimilar mudanças. Há uma harmonia entre os valores que geram a cultura e que estão caracterizados. difundindo assim um ambiente que propicia aprendizagem organizacional. uma cultura que gera aprendizado. 
Este estudo evidenciou que outras ações paralelas e integradas estariam sendo desenvolvidas para melhoria das condições de infra-estrutura, seja das instalações físicas. adequação de equipamentos. e outras. Percebe-se constante preocupação do discurso principalmente da administração do hospital, em não parecer que há uma proposta de substituição das condições estruturais da qualidade do atendimento, reconhecidos como fundamentais, por um modelo baseado somente "no bom relacionamento profissional-paciente". 


\section{CONSIDERAÇÕES FINAIS}

Apesar das dificuldades e resistências, os profissionais de saúde se conscientizaram que a estratégia de assistir a mulher e seus familiares em uma maternidade humanizada garante segurança e qualidade.

A organização estudada se continuar valorizando a qualidade de vida e a excelência do trabalho preocupando-se com estas questões contribuirá para o incremento da auto-estima dos funcionários, e fará com que eles comecem a compartilhar os valores e os objetivos da organização. Será o início da implantação de um espírito de equipe favorável. onde estas começarão a seguir a direção dos objetivos comuns.

Com o desenvolvimento do diagnóstico de Clima Organizacional do HMI pode se observar melhora do ambiente, da harmonia e cooperação em muitos setores. $\mathbf{E} \overline{0}$ imprescindiveis o estimulo desta situação e a manutenção da mesma assim como dos espaços de reflexão que foram criados para o novo momento institucional (implementação da Humanização da Assistência Materno-Neonatal) para que os profissionais continuem refletindo sobre suas práticas, suas atuações e responsabilização profissional.

O fortalecimento e manutenção do Comitê de Acolhimento e Humanização da Assistência Materno-Neonatal do Hospital Maternidade Interlagos. implantado no final desta pesquisa como instrumento de humanização entre a administração/ cliente interno/ cliente externo. Este é formado por um representante efetivo e um ou dois suplentes. eleitos pelos seus pares. teve sua estrutura sedimentada e balizada nos resultados das oficinas. O objetivo da implantação deste Comitê foi, entre outros fatores. implementar em parceria com a Diretoria Institucional. o desenvolvimento de lideres de equipe dos distintos setores de trabalho, ampliando as habilidades dos participantes. facilitando suas condições de gestores de equipes no cotidiano organizacional. Este Comitê aborda temática específica. direcionado à demanda organizacional e à liderança contemporânea. Seus integrantes são compostos por: qualquer funcionário eleito pelos seus pares.

A partir de metas trabalhadas em conjunto com os lideres setoriais de acolhimento. o processo de implantação da humanização da assistência certamente será acelerado devendo colaborar no grande desafio de resgatar a dimensão humana. de 
forma que a equipe de funcionários possa alcançar satisfação e motivação integral. $\mathrm{Na}$ prática, espera-se que os Lideres Setoriais de Acolhimento provoquem mudanças efetivas que conscientizem as equipes da necessidade das suas responsabilidades visando atingir a harmonia. o respeito e a qualidade nas relações de trabalho. Partimos do pressuposto de que será no diálogo, no respeito às diferenças. no trabalho de cooperação e no comprometimento de todos que se manterá e surgirá às relações interpessoais. sadias e solidárias.

Esta modalidade de atenção certamente reforçará o trabalho em equipe interdisciplinar. viabilizando o abandono das rotinas e intervenções obstétricas rotineiras como: uso de enema, tricotomia, jejum no trabalho de parto, manutenção da parturiente no leito com restrição da deambulação espontânea. amniotomia precoce. indução. realização do parto em Centro Cirúrgico sem acompanhante, posição litotômica durante o parto. realização indiscriminada de episiotomia, afastamento do recém nascido da mãe entre três a seis horas de vida.

A estrutura fisica pequena e inadequada do HMI sobretudo a do pré-parto justificou o desencadeamento do projeto de construção do Centro de Parto Normal que é um espaço propicio para exercício da cidadania, pois ali nasce um cidadão, ali a mãe. seu filho e os acompanhantes têm garantidos seus direitos e são tratados como protagonistas principais e participantes do processo de nascimento e não simplesmente sujeitos passivos da ação profissional automatizada e impessoal

Neste espaço pode ser realizado o parto vaginal e endossamos a posição vertical de parir uma vez que as pesquisas demonstraram que as mulheres que deram a luz nesta posição, referiram uma situação enriquecedora e gratificante e que alem do cuidado diferenciado prestado pelos profissionais de saúde. as ações das "amigas da parturiente" nesse momento terão um papel fundamental no nivel de satisfação das mulheres.

As voluntárias do HMI e que exercem as funções de Doulas não estão ocupando o lugar de um profissional já existente, mas sim ocupando um espaço vazio, do acompanhamento contínuo desde a gestação até o puerpério. Não só proporcionar segurança para as mulheres no momento de parir. mas oferecer-lhes aquilo que tinham antigamente e que foi retirado pela civilização contemporânea: o afeto. a parceria. a feminilidade. o calor. a alegria. o sentido de aconchego e segurança dos seus lares. 
Diante do discurso dos funcionários de que o despreparo da mulher no pré-natal representa um entrave no processo de humanização do parto, deverá ser reavaliado a assistência ao pré-natal que ocorre no ambulatório do HMI. Conforme preconiza o MINISTÉRIO DA SAÚDE (2000), o principal objetivo de pré-natal é prestar assistência à mulher desde o início de sua gravidez, onde ocorrem mudanças físicas e emocionais, que cada gestante vivencia de forma distinta. A assistência ao pré-natal é o primeiro passo para o parto e nascimento humanizados.

Temos consciência que. modificações profundas na cultura ocorrem em prazos dilatados. porque necessitam de acomodações nas camadas mais profundas do código de crenças dos profissionais, da administração e dos próprios usuários. $\mathrm{O}$ tempo para que estas reacomodaçôes ocorram é fundamental para a sua solidez.

$\mathrm{O}$ gerente e os lideres setoriais precisam continuar refletindo e não subestimar as reações dos funcionários e nem desprezar o fato de como eles podem influenciar positiva ou negativamente outros indivíduos e grupos durante a implantação das mudanças.A resistência a elas continuará sendo superada a partir do momento que os clientes internos continuarem sendo educados e preparados antecipadamente para as mesmas.

O processo de educação e de comunicação poderá envolver reuniões, discussões. oficinas. relatórios e memorandos. Será que somente o fato de cada gerente ter preparado apresentações audiovisuais, explicando as mudanças e suas razões para os grupos de profissionais envolvidos no processo. a mudança será desencadeada?

Quando a resistência estiver baseada em informaçào ou análise inadequadas e inexatas o programa de educação e comunicação será o mais indicado. Exigirá, porém. um bom relacionamento interpessoal entre os indicadores da mudança e os resistentes. Serão passos imprescindiveis a participação e envolvimento destes em algum aspecto do projeto e da implantação da mudança e dar atenção às suas sugestões. As pessoas envolvidas participando intensamente no projeto e na implementação da humanização da assistência como sujeitos ativos e não meramente como sujeitos passivos. Isto representará inicialmente profunda mudança na filosofia e na cultura organizacional da instituição. pois a participação e o envolvimento dos funcionários deverão ocupar uma posição eminentemente democrática. 
O comprometimento pessoal e íntimo da maioria do cliente interno e ainda a participação da comunidade serão fundamentais para que as transformações continuem acontecendo e tenham pleno êxito.

Outras resistências poderão ser contornadas concedendo facilitação e apoio no sentido de ajudar o cliente interno a se ajustar às transformações necessárias .Estas ações poderão incluir aconselhamento, treinamento interno nas novas funções, planos de desenvolvimento e aquisição de novos conhecimentos e novas habilidades para preparar as pessoas para a inovação. $\dot{E}$ saudável a instituição municiar seu pessoal com as ferramentas e técnicas sobre como fazer a mudança e a inovação. Simplesmente, a instituição divulga entre seus funcionários a tecnologia, o saber fazer, isto é, o conhecimento da mudança. E, cada gerente e lider setorial deverão continuar sendo educados e instruidos sobre os comportamentos de mudança e inovação, visando instruir e educar seus liderados.

Pontos convergentes entre o cliente interno podem ser ressaltados tais como: necessidade de investir em condições estruturais de sustentação da atenção humanizada ao parto e nascimento como a implantação do Centro de parto Normal, apoio à estrutura do Comitê de Acolhimento e Humanização da Assistência Materno-Neonatal; politicas de $\mathrm{RH}$ que reduzam as inseguranças trabalhistas e técnicas; evitar distorções da concepção de "inversão do modelo": ampliar a difusão para a comunidade sobre o programa de Humanização da Assistência sobretudo no ciclo gravídico-purperal. suas diretrizes e normas de funcionamento.

Com o desenvolvimento do programa "Acolhimento e humanização do cliente interno: o caminho mais curto para a humanização da assistência". espera-se que a transformação idealizada pelos clientes interno e tão merecida pelo cliente externo possa de fato ocorrer. tendo em vista que já se observa significativas mudanças ambientais nos diferentes setores do Hospital e Ambulatório e que o HMI seja um espaço propício para exercício da cidadania. pois ali nasce um cidadão, ali mãe e familiares precisam terem garantidos seus direitos. serem tratados como atores participantes do processo de nascimento e não simplesmente sujeitos passivos da ação profissional automatizada e impessoal. 
Espera-se que certos gerentes sejam transformados de controlador, supervisor e conseqüentemente autocrata em educador, orientador. líder, motivador, comunicador $\mathrm{e}$ multiplicador dos esforços de mudança.

Apenas a comunicação/sensibilização não será suficiente para viabilizar as mudanças principalmente no HMI e também no ambulatório. Foi e continua sendo necessário, sobretudo educação. Toda a organização, desde a direção máxima até os funcionários da limpeza deverão estar totalmente sintonizados com os mesmos ideais de mudança e inovação. A convergência de objetivos será fundamental e a maioria dos funcionários já sabem perfeitamente o que fazer, como, quando e onde.

Em referência à violência institucional no HMI serão necessários mais cursos que abordem a subjetividade do profissional e do usuário nas práticas assistenciais e no trabalho multidisciplinar em parceria com o Centro de Desenvolvimento de Recursos Humanos da SES-SP. enfocando entre outras variáveis a saúde psíquica do trabalhador de saúde. e ao mesmo tempo criando metodologia de transmissão e construção de saber coletivo sobre o tema.

Analisando a relação entre trabalho e saúde, através de atividades realizadas com auxiliares de enfermagem e enfermeiras do HMI, que atuam junto ao berçário e alojamento conjunto. dentro da questão trabalho e saúde, foi enfocado. mais especificamente, as fontes geradoras de estresse psíquico para esses trabalhadores. Consideram que o programa Acolhendo o Cliente Interno é fundamental. pois este colabora no processo e na forma de organização do trabalho. Através do Diagnóstico de Clima Organizacional da instituição, foi fornecido subsídios ao Comitê de Acolhimento e Humanização da Assistência. acerca dos pontos negativos e positivos do HMI e seu Ambulatório. entre outros fatores a existência de riscos e cargas geradores de desgaste com conseqüentes repercussões para a saúde física e mental dos trabalhadores.

$O$ novo contexto social traz novos desafios para o acolhimento $\mathrm{e}$ desenvolvimento de ações de humanização com o cliente interno. Solicita-se das instituições formadoras de Recursos Humanos para a saúde da formação de cidadãos criticos. capazes de compreender as implicações do desenvolvimento cientifico. tecnológico e econômico para sua qualidade de vida e atuação profissional. É preciso reconhecer que. em uma sociedade em que a tecnologia se faz presente em vários 
contextos, estas são importantes ferramentas, mas também não se deve deixar seduzirse por elas.

Espera-se que. como resultado do trabalho em equipe podera se instalar uma boa comunicação entre as diferentes áreas e membros, conseqüência do início do "empoderamento" dos funcionários, sendo possivel eles expressarem em liberdade e confiança suas idéias e sentimentos. 


\section{REFERÊNCIAS}

Alvarães A. Pesquisa de clima organizacional: medindo a temperatura da empresa. [on-line]. São Paulo. Disponível em: <URL: http://www.rh.com.br/ler.php?cod=3263>. [2002mar 26].

Amick BC, Celentano DD. Structural determinants of the psychosocial work environment: introducing technology in the work stress framework. Ergonomics 1991; 34 (5): 625-46.

Atallah NA, Castro AA. Medicina baseada em evidências: o elo entre a boa ciência e a boa prática clínica. Diagnóstico e Tratamento 1997; 54-55.

Ballint M. O bom médico. Rev Bras Educ Méd 1997; 21 (1): 39-46.

Barbaut J. O nascimento através dos tempos e dos povos. Lisboa: Terramar; 1990.

Baremblitt G. Compêndio de análise institucional e outras correntes: teoria e prática. Rio de Janeiro: Rosa dos Tempos; 1992.

Basile ALO. Schirmer J, Ribeiro MI. Implantação de um centro de parto normal. Rev Paul Enf 2002; 2 (21).

Bennis WG. Os gênios da organização: as forças que impulsionam a criatividade das equipes de sucesso. Rio de Janeiro: Campus; 1999.

Berquó E. Brasil, um caso exemplar, anticoncepção e partos cirúrgicos, a espera de uma ação exemplar. Estud Fem 1993; 1 (2): 366-81.

Brinkerhoff RO, GILL SJ. The learning alliance: systems thinking in human resource development. San Francisco: Jossey-Bass; 1994. 
Calder B. Focus group and the nature of qualitative marketing research. J. Marketing Res 1977; (14): 353-64.

Camano L. O "absurdo do abuso" na arte e ciência obstétrica - Índice abusivo de cesáreas pode ser contornado com a volta do professor na sala de parto. Sogesp, 1999;

Caplan S. Using focus group methodology for ergonomic design. Ergonomics 1990; 33 (5): $527-33$.

Chen HT. Theory-driven evaluations. Newbury Park: Sage Publications; 1990.

Cochrane Library. Issue 3, 2001. OXFORD: update Sofware. Disponivel em: $<$ http://www.bireme.br/cochrane/>. [2001 Dez 31].

Codo W. Cidadania, trabalho e saúde mental: notas para um debate. In: Encontro Nacional da ABRASCO; 1993; São Paulo (BR). São paulo;1993.

Collingwood J, Collingwood, C. The NLP Field guide: part 1: a reference manual of practitioner level patterns publisher: Sydney: Emergent Publications; 2001.

Conselho Federal de Medicina. Natural é parto normal (Campanha). Cesáreas: vergonha nacional, JCFM 1997 nov; 10 (87): 18-19.

Conselho Regional de Medicina do Estado de São Paulo. Parto normal pede passagem; Reduzir cesáreas e melhorar a qualidade da assistência obstétrica. CREMESP 1997 (N Esp): 7-9.

Davis-Floyd $R$. Birth as an american rite of passage. Berkeley: University of California Press; 1992.

Davis-Floyd R. Sargent C, (editor). Introduction. Childbirth and authoritative knowledge: cross-cultural perspectives. Berkeley: University of California Press; 
1997. Introduction.

Dejours C. A loucura do trabalho. $3^{\text {a }}$ ed. São Paulo: Cortez; 1988.

Dejours C, Dessors D, Desriaux F. Por um trabalho, fator de equilibrio. Rev Adm Empres 1993; 33 (3).

Deslandes SF. Análise do discurso oficial sobre humanização da assistência hospitalar. Ciênc Saúde Coletiva 2004; 9 (1): 7-14.

Diniz CSG. Entre a técnica e os direitos humanos: Possibilidades e limites da humanização da assistência ao parto. São Paulo; 2001. [Tese de Doutorado Faculdade de Medicina da USP].

Douglas M. How institutions think. Syracuse, Nova York: Syracuse University Press; 1986.

Falconi Filho A. Programação neurolinguística. [on-line]. Disponivel em: <URL: http://www.acessa.com/viver/arquivo/ser_holistico/2004/02/12-pnl/>. [2004 fev 12].

Flood RL. Rethinking the fifth discipline: learning with the unknowable. Londres: Routledge; 1999.

Forrester K. Agression and assault against nurses in the workplace: practices and legal Issues, J.Law.Med 9 (4):386-91, 1977.

Fox RC. Is there a new medical student? A comparative view of medical socialization in the 1950 and the 1970s. In: Fox RC. Essays in medical sociology: journeys into the field. $2^{\text {nd }}$ ed. New Brunswick: Transaction Books; 1998. p. 78-101.

Gil AC. Métodos e técnicas de pesquisa social. São Paulo: Atlas; 1999.

Godoy AS. A pesquisa qualitativa e sua utilização em administração de Empresas. Rev 
Adm Empres 1995; 35 (4): 65-71.

Heloiani JR, Capitão CG. Saúde mental e psicologia. S Paulo perspect 2003; 17 (2): 102-05.

Jewkes R, Abrahams NMVO Z. Why do nurses abuse patientes? Reflections from South African obstetric service. Soc Sci Med 1998; 47(11): 1781-795.

Jones RH. Humanização do parto: qual o verdadeiro significado? Disponível em: <URL: http://www.amigasdoparto.com.br/ac015.html>. [2001 dez 31].

Jones RH. As metamorfoses do parto: como o parto passou a ser assunto médico. Disponivel em: <URL: http://www.amigasdoparto.com.br/ac007.html>. [2002 mar 26].

Jones RH. Memórias do homem de vidro: reminiscências de um obstetra humanista.Porto Alegre, 2004.

Kervasdoué J. A saúde e o sistema de saúde na França. Disponível em: <URL: http://www.france.org.br/abr/imagesdelafrance/Formato\%20PDF/saude.pdf $>$. [2002 jul 15].

Klaus MH, Kennel JH. The doula: an essential ingredient of childbirth rediscovered. Acta Paediatr 1997; 86: 1034-6.

Kray L., Gonzalez R. Differential weighting in decision versus advice: i'll do this, you do that. J Behav Decision Making 1999; 12:207-17.

Kray L. Contingent weighting in self-other decision making. Organ Behav Hum Decision Proc 2000; 83: 82-106.

Krueger RA. Focus group: a practical guide for applied research. Thousand Oaks:SAGE; 1994. 
Lèfevre F, Lefêvre AMC, Teixeira JJV, organizadores. O discurso do sujeito coletivo: uma nova abordagem metodológica em pesquisa qualitativa. Caxias do Sul: EDUCS; 2000a.

Lèfevre F, Lèfevre AMC. A fala do social II. São Paulo; 2000b.

Leikind BJ, McCarthy WJ. An investigation of firewalking. In: Buffalo KF, editor. The hundreth monkey and other paradigms of the paranormal. New York: Prometheus Books; 1991.

Light D. Uncertainty and control in professional training. J Health Soc Behav 1979; 20:310-22.

Lippi UG, Ribeiro Neto JÁ, Rattner D. Parto por enfermeira ou reforma na obstetrícia? [Debate] Rev Ser Méd 1998: 22-9.

Litwin G, Stringer R. Motivation and organizational climate. Boston: Harvard University Press; 1968.

Luz R. Clima organizacional. Rio de Janeiro: Qualitymark; 1995.

Mariotti H. Organizações de aprendizagem: educação continuada e a empresa do futuro. São Paulo: Atlas; 2000.

Melchior R. Avaliação da organização da assistência ambulatorial a pessoas vivendo com HIV/AIDS no Brasil. São Paulo; 2003. [Tese - de Doutorado Faculdade de Saúde Pública da USP]

Merhy EE. Em busca do tempo perdido: a micropolítica do trabalho vivo em saúde. In: MERHY EE., ONOCKO R, organizadores. Agir em saúde: um desafio para o público. São Paulo: Hucitec/Lugar Editorial; 1997. p. 71-112. 
Merhy EE. Saúde: a cartografia do trabalho vivo. São Paulo: Hucitec; 2002.

Minayo MCS. O desafio do conhecimento: pesquisa qualitativa em saúde. São Paulo/Rio de Janeiro: Hucitec/Abrasco; 1998.

Ministério da saúde. Programa de humanização no pré-natal e nascimento. Brasília, 2000.

Ministério da Saúde. Parto, aborto e puerpério: assistência humanizada à mulher. Brasilia: Centro de Documentação do Ministério da Saúde; 2001 la.

Ministério da Saúde. Programa Nacional de Humanização da Assistência Hospitala - PNHAH. Brasília, 2001b.

Ministério da Saúde. Sistema de Informações de Nascidos Vivos (SINASC) [on-line]. Disponível em: <URL: http:// www.saude.sp.gov.br/ dsaude/ informes/ 7saude_mulher/html/saude_mulher.htm>. [2002 abr 13].

Moraes Araújo SDT. Decisão médica e tipo de parto: relação entre discurso e prática. São Paulo; 2005. [Tese - de Doutorado - Hospital do Servidor Público Estadual].

Neme B. Obstetrícia básica. $2^{\mathrm{a}}$ ed. São Paulo, Sarvier; 2000.

Newstrom DK, John W. Comportamento humano no trabalho. São Paulo: Pioneira; 1996. v.2.

Nogueira MLA. Residência médica: um estudo prospectivo sobre dificuldades na tarefa assistencial e fontes de estresse. São Paulo; 1994. [Tese - Escola Paulista de Medicina]. 
Odent M. Birth and the origins of viiolence. Primal Health Research 1994; 2 (3).

Odent M. A cientificação do amor. São Paulo: Terceira Margem: 2000.

Orretveit J. Purchasing for health gain: the problems and prospects for purchasing for health gain in the 'managed markets' of the NHS and other European health systems. European Journal of Public Health 1993; 3:77-84.

Paciornick M. Aprenda a viver com os indios: o parto de cócoras, desempenho sexual, ginástica índia, comer e descomer. Rio de Janeiro: Espaço e Tempo: 1987.

Parasuraman A. Marketing research. Toronto: Addison-Wesley. 1986.

Parolin SRH. A criatividade nas organizações: um estudo comparativo das abordagens sociointeracionistas de apoio à gestão empresarial. Cad Pesq Adm 2003; 10 (1): 9- 26.

Pereira MJB. O trabalho da enfermeira no serviço de assistência domiciliar potência para (re) construção prática de saúde e de enfermagem. Ribeirão Preto: 2001. [Tese de Doutorado - Escola de Enfermagem de Ribeirão Preto da USP].

Perestrello D. A medicina da pessoa. Rio de Janeiro: Atheneu: 1982.

Petterson B. Leadbetter. D. Bowie. V. Supporting nursing satff exposed to violence at work. Inter J Nurs Stud 1999: 36: 479-86.

Porreco RP. High cesarean section rate: a new perspective. Obstet Gynecol 1985: $65: 307-11$.

Rattinger H. Sicherheitspolitik der Bundesrepublik Deutschland: Eine Einfuehrung in ihre buendnispolitischen Grundlagen. Berlin: Colloquium. 1988.

Rattner D. Subsídios para a avaliação da qualidade do processo de assistência ao 
Rattner D. Subsídios para a avaliação da qualidade do processo de assistência ao parto. São Paulo; 1991. [Tese - Faculdade de Saúde Pública da Universidade de São Paulo].

Rattner D. Sobre a hipótese de estabilização das taxas de cesáreas do Estado de São Paulo, Brasil. Rev Saúde Pública 1996; 30:19-33.

Recureda López JA. Influencia del apoyo profesional en la mejora del trabajo de parto. Enferm Cient 1999; 206 (207): 55-9.

Riesco MLG. O preparo da gestante para o parto na formação da enfermeira obstetra. Rev Paul Enferm 1994; 13 (1/3): 39-46.

Rivera FJU. Cultura e liderança comunicativa. In: Rivera FJU, organizador. Análise estratégica em saúde e gestão pela escuta. Rio de Janeiro: Fiocruz; 2003. p. 185-218.

Robbins S. Comportamento organizacional. $8^{\mathrm{a}}$ ed. Trad. de Christina Ávila de Menezes. Rio de Janeiro: LTC; 1998.

Robertson A. Empowering women: checking active birth. Sidney, Australia: ACE Graphics; 1994.

Ryan R, Deci EL On happiness and human potential: review of rescearch on hedonic and eudamonic Well-being. Ann Rev Psycol 2001; 52: 141-66

Scalabrin AC, Casado T. Do hedonismo à eudaimonia: tratado de bem estar psicológico no trabalho. São Paulo; 2002. [Tese - Faculdade de Economia, Administração e Contabilidade da USP].

Schiehll E, Morissette R. Motivation, measurement and rewards from a performance evaluation perspective. RAC 2000; 4 (3): 7-24. 
Schirmer J. Assistência ao parto: novas medidas adotadas pelo Ministério da Saúde. São Paulo: Acta Paul Enf 2000; 13: 22.

Schulenburg JMG. Forming and reforming the market for thirdy-party purchasing of health care: a german perspective. Soc Sci Med 1994; 39:1.473-1.481.

Schumutte P, Ryff C. Personality and well-being: reexamining methods and meanings. J Persona Soc Psychol 1997; 73 (3): 549-559.

Secretaria de Estado da Saúde. Humanização da assistência. São Paulo: Coordenação dos Institutos de Pesquisa; 2003.

Secretaria de Estado da Saúde. Comitê Estadual de Vigilância a Morte Materna (CEVMM). São Paulo; 2004.

Secretaria Municipal de Saúde. Boletim CEINFO ,Distritos de Saúde. 2002.

Silva RC. Metodologias participativas para trabalhos de promoção de saúde e cidadania. São Paulo: Vetor; 2002.

Tanaka ACA, Mitsuiki L. Estudo da mortalidade materna em 15 cidades brasileiras. São Paulo: Unicef; 1999.

Toledo F, Millioni B. Dicionário de recursos humanos. $3^{\mathrm{a}}$ ed. São Paulo: Atlas; 1986.

Triviños ANS. Introdução à pesquisa em ciências sociais: a pesquisa qualitativa em educação. São Paulo: Atlas; 1992.

Wagner M. Pursuing the birth machine: the search for appropriate perinatal technology. London/Sydney: ACE Graphics; 1994.

Wilheim J. A caminho do nascimento: uma ponte entre o biológico e o psíquico. $2^{\mathrm{a}}$ ed. São Paulo: Casa do Psicólogo; 2003. 
World Health Organization (WHO). Family and reproductive health. Safe motherhood unit. maternal and newborn health care in normal birth: a practical guide. Report of a Technical Working Group. Geneva; 1996. 54p.

\section{CONSULTAS}

Almeida Junior ALMVM. O paradoxo estratégico-gerencial do nosso tempo: a centralização de poder e a busca pela humanização das empresas. São Paulo; 2002. [Dissertação de Mestrado- Fundação Getúlio Vargas ].

Bardin L. Análise de conteúdo. Trad. de Luis Antero Reto e Augusto Pinheiro. Lisboa: Edições 70; 1997.

Becker HS. Métodos de pesquisa em ciências sociais. $3^{\text {a }}$ ed. São Paulo: Hucitec; 1997.

Bertoni RB. O agir humano como um desvio necessário do equilibrio contigente. São Paulo; 2002. [Dissertação de Mestrado- Fundação Getúlio Vargas ].

Casagrande RJ. Valores organizacionais: uma análise no contexto educacional. São Paulo; 2001. [Dissertação de Mestrado- Fundação Getúlio Vargas ].

Contadiopoulos AP, Champagne F, Povtin L, Denis JL, Bijle P. Saber preparar uma pesquisa. São Paulo: Hucitec, Rio de Janeiro. Abrasco; 1997.

Donabedian A. Criteira, Norms and Standards of Quality: What Do They Mean? AJPH, 1981; 71 (4): 409-12.

Festinger L, Katz D. A pesquisa na psicologia social. Rio de Janeiro: FGV; 1984.

Guerra Al. Influência dos estilos gerenciais no clima organizacional São Paulo; 2000. [Dissertação de Mestrado- Fundação Getúlio Vargas ]. 
Haim M. Diferenças principais entre líderes e gerentes e seus respectivos papéis na organização São Paulo; 2003. [Dissertação de Mestrado- Fundação Getúlio Vargas ].

Lèfevre F; Lefêvre AMC. Os novos instrumentos no contexto da pesquisa qualitativa. In: Lèfevre $\mathrm{F}$, Lefêvre $\mathrm{AMC}$, Teixeira JJV, organizadores. $O$ discurso do sujeito coletivo: uma nova abordagem metodológica em pesquisa qualitativa. Caxias do Sul: EDUCS; 2000. p. 11-35.

Lima EE. A percepção da comunidade interna: um estudo de caso. São Paulo; 2001. [Dissertação de Mestrado- Fundação Getúlio Vargas ].

Lund MLMP. Limites e possibilidades da gestão holística. São Paulo; 2002. [Dissertação de Mestrado- Fundação Getúlio Vargas ].

Minayo MCS, Deslandes SF, Cruz-Neto O, Gomes R. Pesquisa social: teoria, método e criatividade. Petrópolis: Vozes; 1995.

Organização Nacional de Acreditação. Manual das organizações prestadoras de serviços hospitalares. Pelotas, RS: Editora da Universidade Católica de Pelotas; 2001. 


\section{ANEXOS}

\section{ANEXO 1 - AVALIAÇÃO DE CLIMA ORGANIZACIONAL}

Para finalidades práticas, assim definimos Clima Organizacional: é a maneira como nos sentimos no ambiente de trabalho. Você encontrará abaixo descrições das principais dimensões do Clima Organizacional. Sua tarefa é avaliar dois aspectos básicos. Para isso. você usará sua sensibilidade e poder de observação. Os aspectos são:

- O Clima Organizacional Atual (A) Isto é: como você acha que a situação está no momento.

- O Clima Organizacional Ideal (I) Ou seja: como você acha que a situação deveria estar.

\section{Como Preencher o Questionário.}

Para cada item você dará uma pontuação, de 1 a 10. Isso será feito colocando a letra A acima da pontuação que você der para o Clima Organizacional Atual, e uma letra I acima da que for dada para o Clima Organizacional Ideal, que você considera como o estado desejado.

1. CONFORMISMO - Quando a instituição é muito rigida. seus membros sofrem limitações excessivas. Há regras demais. As pessoas gostariam de ter mais liberdade para trabalhar. No entanto. acabam aceitando a situação. Nesta instituição (unidade administrativa. posto de saúde, hospital. etc.), o grau de conformismo é:

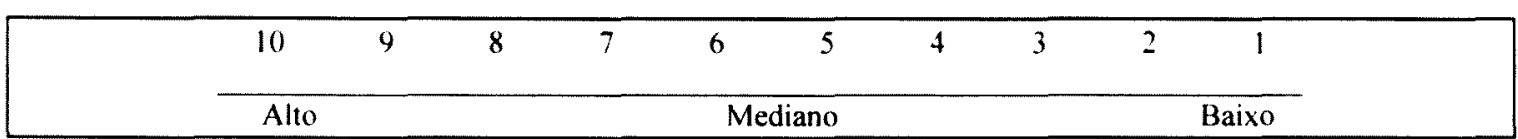

2. RESPONSABILIDADE - Em condições satisfatórias, a diretoria (chefia) delega bastante responsabilidade aos funcionários. Isso permite que eles tenham liberdade para tomar decisões e resolver problemas, sem precisar a todo momento perguntar a um superior o que fazer. Nesta instituição o nível de delegação de responsabilidade é:

\begin{tabular}{|l|l|l|l|l|l|l|l|l|l|}
\hline 1 & 2 & 3 & 4 & 5 & 6 & 7 & 8 & 9 & 10 \\
\cline { 2 - 6 } & Pouca ou nenhuma & & \multicolumn{1}{|c|}{ Mediana } & & & & Alta \\
\hline
\end{tabular}

\section{MOTIVAÇÃO E COMPROMETIMENTO COMPARTILHADO - Em} condições ideais. a diretoria (chefia) valoriza a qualidade de vida e a excelência do 
trabalho e se preocupa com elas. Isso aumenta a auto-estima das pessoas, e faz com que elas compartilhem os valores e objetivos da instituição. Nesta instituição o nível de motivação e comprometimento é:

\begin{tabular}{|c|c|c|c|c|c|c|c|c|}
\hline 1 & 2 & 3 & 4 & 5 & 6 & 7 & 8 & $\begin{array}{ll}9 & 10\end{array}$ \\
\hline & eno & & & & iano & & & Grande \\
\hline
\end{tabular}

4. RECOMPENSAS - Representam o grau em que os membros da instituição sentem que estão sendo reconhecidos e recompensados pelo seu trabalho, e não ignorados. criticados e punidos com freqüência. Nesta instituição, o nivel de recompensas é:

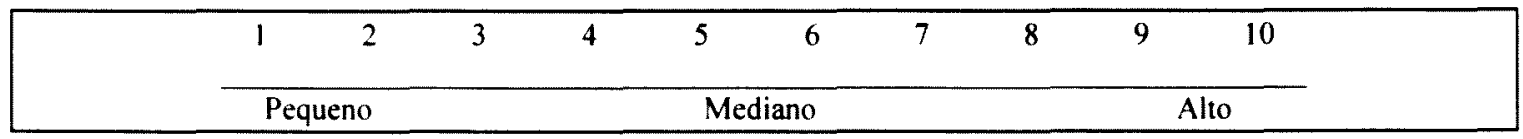

5. COMUNICAÇÃO E CLAREZA ORGANIZACIONAL - Representa o grau de ordem, bom funcionamento, transparência de atitudes e clareza de definição de objetivos da instituição. Nesta instituição, o nível de clareza organizacional é:

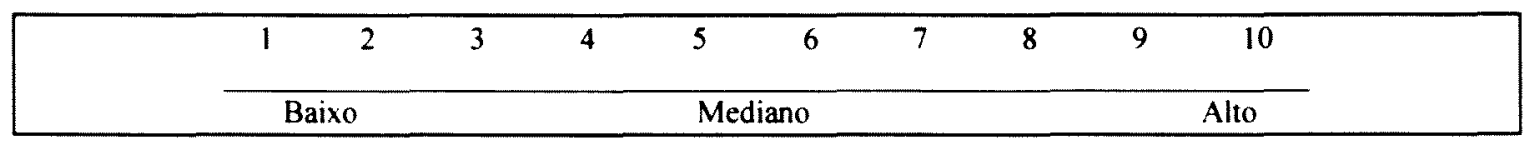

6. CALOR HUMANO E APOIO - Esta dimensão reflete a amizade e o entendimento que devem existir na instituição. Os membros confiam uns nos outros e se apóiam mutuamente. Nesta instituição o grau de calor humano é:

\begin{tabular}{|llllllllll|}
\hline 1 & 2 & 3 & 4 & 5 & 6 & 7 & 8 & 9 & 10 \\
\hline & Baixo & & & & & & \\
\hline
\end{tabular}

7. VERTICALIDADE - Significa excesso de hierarquia e pouca flexibilidade. A tendência predominante é para o autoritarismo e rigidez de atitudes e posições. Nesta instituição. o nivel de verticalidade é:

\begin{tabular}{|lllllllllll|}
\hline 10 & 9 & 8 & 7 & 6 & 5 & 4 & 3 & 2 & 1 \\
\hline & Alto & & \multicolumn{1}{|c|}{ Mediano } & & & & Baixo \\
\hline
\end{tabular}

8. HORIZONTALIDADE - Representa o grau de informalidade de uma instituição. Ele é muitas vezes excessivo, e nesses casos surgem com freqüência boatos, intrigas de 
corredor e ressentimentos. A horizontalidade em si não é um mal; o que se deve evitar é a sua extensão além dos limites razoáveis. Nesta instituição o nível de horizontalidade é:

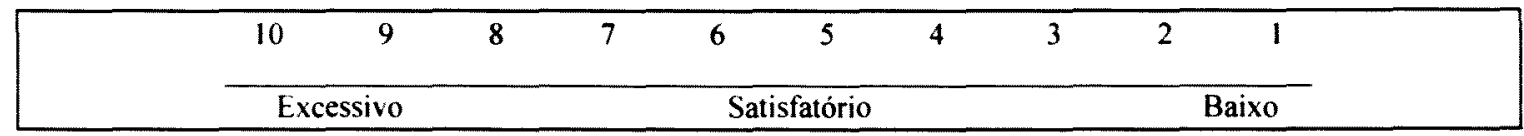




\section{ANEXO 2 - FORMULÁRIO DE CONSENTIMENTO INFORMADO}

\section{Somente para os profissionais de saúde, gerentes de saúde e outros profissionais} que trabalham na instituição estudada (Hospital Maternidade Interlagos e seu

$$
\text { Ambulatório - SES-SP) }
$$

\section{FORMULÁRIO DE CONSENTIMENTO INFORMADO}

Estamos fazendo uma pesquisa no Hospital Maternidade Interlagos e no Ambulatório com o objetivo de melhorar o atendimento ao parto, e para saber mais sobre o que os profissionais de saúde, os administradores, pensam a respeito da assistência humanizada ao parto e nascimento. A pesquisa faz parte de um programa de doutorado - Departamento de Epidemiologia da Faculdade de Saúde Pública da Universidade de São Paulo.

Para isso, estamos acompanhando o atendimento prestado pelos profissionais desta instituição, a começar do guarda que fica na entrada da instituição até o administrador geral, incluindo os profissionais que estão prestando assistência direta no processo do trabalho de parto, parto e puerpério de algumas paturientes admitidas neste serviço. Sua participação é totalmente voluntária, mas seu depoimento pode ser de grande valia na melhoria da qualidade dos serviços de atenção materno-infantil.. Se você aceitar fazer parte da pesquisa, será garantido sigilo total do autor das informações. seu nome não vai aparecer em nenhum lugar, pois você pode escolher um nome falso. se assim o desejar.

Se você não quiser participar da pesquisa, não terá nenhum problema. nenhum constrangimento para o desenvolvimento de suas atividades aqui no hospital e/ou ambulatório.

Você tem alguma dúvida? (Anotar e responder as dúvidas, eventualmente incluí-la como esclarecimento, por escrito)

Consentimento para a realização da entrevista

( ) SIM. consinto ( ) NÃO consinto

Como você quer que o seu nome apareça (escolha um nome falso) 
Você tem alguma dúvida? (Anotar e responder as dúvidas, eventualmente incluí-la como esclarecimento, por escrito)

Se eu necessitar consultar a sua ficha profissional para entender melhor o seu depoimento, você me autoriza?

Você tem alguma dúvida? (Anotar e responder as dúvidas, eventualmente incluí-la como esclarecimento, por escrito)

Consentimento para acesso ao prontuário e/ou currículum

( ) SIM, consinto ( ) NÃO consinto

Nome do profissional por extenso

Assinatura do profissional

Assinatura da pesquisadora

de

de 2002 . 


\section{ANEXO 3 - Roteiro para os Grupos Focais}

1. Fale sobre os pontos negativos (pontos de desumanização) do seu setor de trabalho e da instituição como um todo.

2. Você acha que é possivel os pontos negativos serem eliminados ou transformarem-se em positivos?

3. Após reflexão acerca dos pontos negativos, do que e de quem depende a superação destes pontos negativos? Você pode ser franco e dizer tudo que você achar, sem medo de nenhuma represália. Se você não quiser falar pode escrever no papel o que você e/ou os seus companheiros pensam. Não é necessário se identificar, todavia é importante que você identifique o seu setor de trabalho ou o setor aonde você aponta os pontos negativos.

4. Sua opinião é importantíssima! Dê sugestões de melhora a curto, médio e longo prazo.

5. Fale sobre os pontos positivos (pontos de humanização) do seu setor de trabalho e da instituição como um todo.

6. Dê sugestões de como manter e/ou incrementar os pontos positivos.

7. Se desejar. fale ou escreva como você se sente no seu setor de trabalho e na instituição como um todo. 


\section{ANEXO 4 - Roteiro das Entrevistas em profundidade}

Trata-se de uma pesquisa de uma Tese de Doutorado do Departamento de Epidemiologia da Faculdade de Saúde Pública da USP.

Título do Trabalho: Humanização da Assistência Materno-Neonatal sob a ótica da Epidemiologia

1- Por que optou por esta profissão/especialidade?

2- Por que você escolheu este hospital para trabalhar? Conte-me um pouco sobre como você chegou até aqui?

3- Você está satisfeito com o seu desempenho aqui? O que precisa ser melhorado?

4- O que você entende por Humanização da Assistência Materno-Neonatal? (Pré-natal. Parto e Puerpério Humanizados).

5- Cite itens gerais de Humanização e da Assistência Materno-Neonatal nesta instituição?

6- Cite itens de deshumanização de modo geral e da Assistência Materno-Neonatal nesta instituição?

7- Você acha que a estrutura fisica deste hospital atrapalha a humanização?

8- Qual o profissional que mais atrapalha no processo de Humanização? Porque?

9- Qual o que mais colabora no processo de humanização? Porquê?

10- Você acha que o atendimento ao pré-natal influência o processo de humanização?

11- Você acha que a história de vida dos profissionais influência o processo de humanização?

12- Você acha que a história de vida da paciente influência o processo de humanização? 


\section{ANEXO 5 - Parte dos resultados das entrevistas em profundidade}

\section{DISO URSO DO SUJFITO COLETIVO}

\section{Por que optou por esta profissão /especialização?}

\begin{tabular}{|c|c|}
\hline $\begin{array}{l}\text { IDEI.A } \\
\text { CENTRAL.A }\end{array}$ & $\begin{array}{l}\text { Médicos (Obstetras, Neonatologistas, Anestesiologistas, U'TI Materno } \\
\text { e Neonatal) }\end{array}$ \\
\hline $\begin{array}{c}\text { Por } \\
\text { vocação }\end{array}$ & $\begin{array}{l}\text { Optei por ser médica porque eu sempre gostei dessa área da saúde, eu sempre fui ligada a } \\
\text { isso. A ginecologia-obstericia é uma área da medicina que eu acho extremamente } \\
\text { humana, de muito contato. É uma área que envolve muitas coisas, envolve clínica, } \\
\text { envolve cirurgia, envolve psicologia, chega bem perto da intimidade da paciente, você } \\
\text { pode cuidar da paciente como um todo. Desde a minha formação na faculdade que eu } \\
\text { sempre tive inspiração por obstetrícia, porque eu acho que é uma parte muito bonita, ver a } \\
\text { vida fluindo que é o nenenzinho nascendo, é uma nova vida. Eu acho que tem tudo de } \\
\text { muito bonito. Eu sempre tive interesse em ajudar as pessoas. Eu gosto da parte de } \\
\text { obstetrícia, do nascimento em si. Sempre foi um sonho, um sonho de criança, era uma } \\
\text { vontade desde criança, e graças a Deus eu consegui realizar essa vontade. Então, até hoje } \\
\text { eu me sinto realizada, mas eu quero realizar ainda mais. Desde a infầncia que eu tenho } \\
\text { interesse. Na escola eu gostava de biologia, acabei me dedicando na área de biológica; no } \\
\text { final prestei vestibular. Gosto. gosto da minha profissão de médico primeiro e depois sou } \\
\text { ginecologista obstetra. Gosto de coraçăo. A área que a gente passou na faculdade foi a } \\
\text { área de pediatria e berçário, que engloba a neonatologia, que foi a área que mais me } \\
\text { chamou a atenção, dos cuidados com o bebê. Então, eu achei que eu me identifiquei } \\
\text { melhor nesta área, acho que eu gosto mais, sinto mais prazer de trabalhar nesta área do } \\
\text { que com adulto. Eu sou pediatra, eu gosto muito de criança. Me identifiquei na minha } \\
\text { formação profissional enquanto pediatra, depois foi surgindo as oportunidades, as portas } \\
\text { foram se abrindo. Eu tive a oportunidade de ser neonatologista. Eu abracei e acabei me } \\
\text { adaptando e me sinto bem nessa parte da medicina. Me sinto segura. } \\
\text { Sujeitos: (RB, RC. RA, Ol, O3, O2, N1, N3, N4) }\end{array}$ \\
\hline
\end{tabular} Direção do HMI e Ambulatório

Afi
Afinidade profissional. A opçăo ocorreu quando estava no colegial, durante as aulas de psicologia. o tema era interessante o que me levou a novas leituras e a escolha da profissão. A Maternidade sempre foi uma coisa que me sensibilizou muito. A especialidade ginecologia/obstetricia, na maioria das vezes ela vem puxada inicialmente pela obstetrícia; a gente começa fazendo partos, normalmente é o primeiro contato que a gente tem com a parte prática da medicina. Depois de algum tempo é que as pessoas escolhem se vai ser obstetra, ou se vai ser ginecologista. Mas, a formaçåo inicial de todo mundo é de ser um obstetra. E eu sempre me dediquei muito a obstetrícia, eu sou um obstetra, sempre fui um obstetra, sempre fui uma pessoa admiradora da maternidade. Essa entidade maternidade sensibiliza a todos nós. Obstetrícia é uma especialidade gratificante. é uma especialidade de muita alegria, uma especialidade de muito conforto, de muito calor humano. Então isso aí atrai quem é muito ligado nesses itens. Eu gosto de cuidar das pessoas. Eu me sinto bem. Eu me dôo. Eu acho importante. A minha profissão é uma coisa que eu amo de paixão. Também Gosto do trabalho administrativo. Eu gosto de administrar saberes.

Sujeitos: (DA, DG, DC, DU, DE)

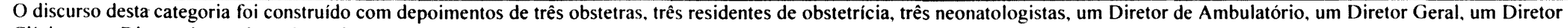
Clínico, um Diretor de Apoio ao Usuário e uma Diretora de Enfermagem. 


\section{DISCURSO DO SUJEITO COLETIVO}

\section{Por que optou por esta profissão lespecialização?}

\begin{tabular}{|c|c|c|c|}
\hline $\begin{array}{c}\text { IDEIA } \\
\text { CENTRALA }\end{array}$ & $\begin{array}{l}\text { Profissionais da área } \\
\text { Administrativa }\end{array}$ & Outros profissionais da área Assistencial & \begin{tabular}{|c} 
Lideres Setoriais \\
de Acolhimento
\end{tabular} \\
\hline $\begin{array}{c}\text { Por } \\
\text { vocação }\end{array}$ & $\begin{array}{l}\text { Em } \text { I }^{\circ} \text { lugar optei porque eu gosto da } \\
\text { profissão, desde criança eu sempre } \\
\text { sonhei em trabalhar na área de } \\
\text { segurança. com público. Quando eu } \\
\text { era criança eu queria ser polícia, já } \\
\text { que eu não sou policia eu vou ajudar a } \\
\text { população de outra maneira. Então eu } \\
\text { tenho essa facilidade de lidar com o } \\
\text { público, por isso que eu optei por esta } \\
\text { área da segurança. Eu gosto desde } \\
\text { criança. A gente pode estar ajudando } \\
\text { no que pode. } \\
\text { Sujeitos: (S4.S2) }\end{array}$ & 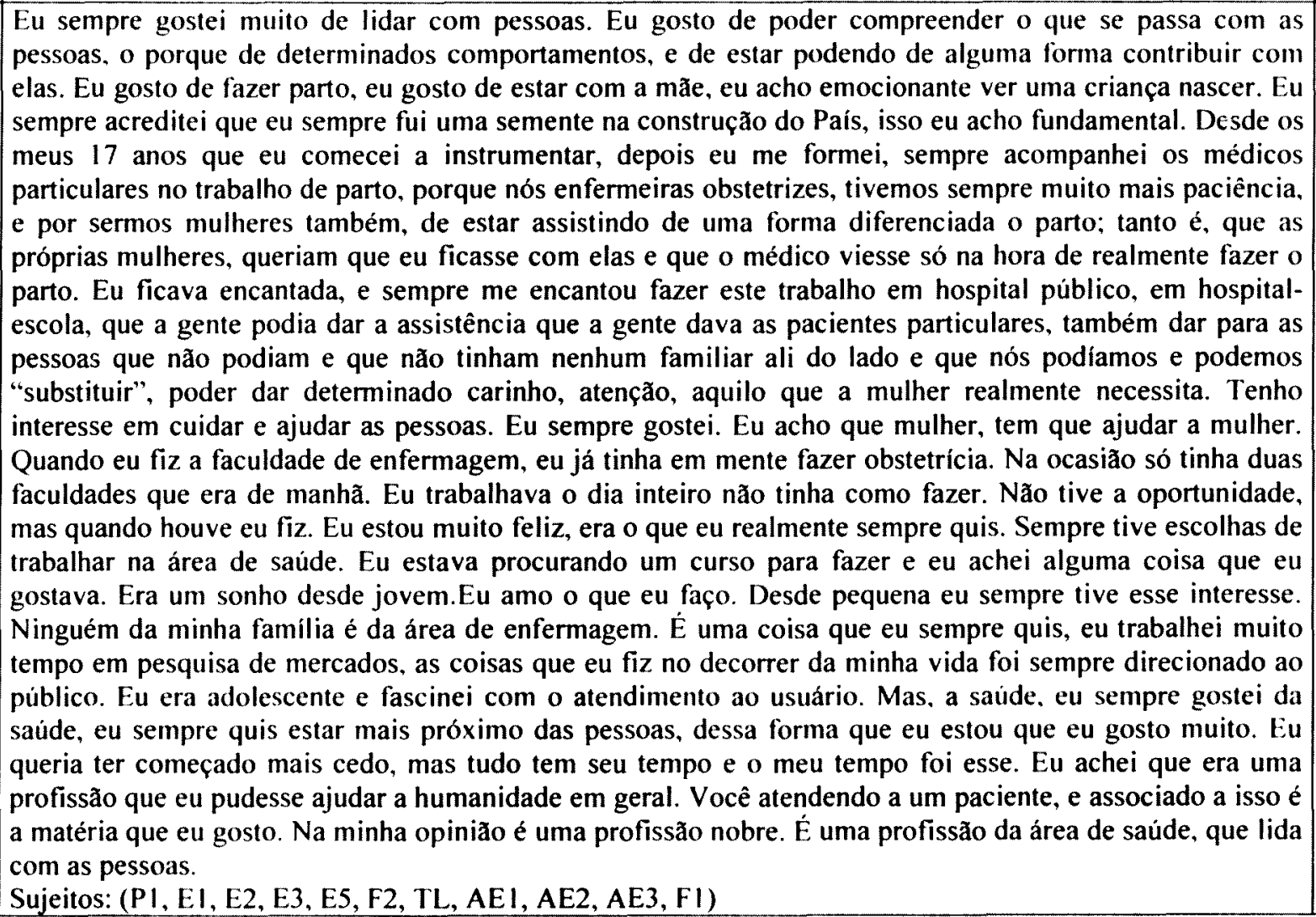 & \\
\hline
\end{tabular}




\section{DISCURSO DO SUJFITO COLFTIVO}

\section{Por que optou por esta profissão lespecialização?}

\begin{tabular}{|c|c|c|c|}
\hline $\begin{array}{c}\text { IIDEIA } \\
\text { CENTRALB }\end{array}$ & Profissionais da área Administrativa & $\begin{array}{l}\text { Outros profissionais } \\
\text { da área Assistencial }\end{array}$ & $\begin{array}{l}\text { Lideres Setoriais } \\
\text { de Acolhimento }\end{array}$ \\
\hline $\begin{array}{l}\text { Por maiores } \\
\text { oportunidades } \\
\text { de trabalho }\end{array}$ & $\begin{array}{l}\text { Năo tive outra opção, eu estou fazendo porque é uma questão de desemprego, mas eu gosto da profissão. Tem } \\
\text { mais campo de trabalho essa profissão, por isso que eu optei. Optei, devido o campo de trabalho. Também } \\
\text { está sendo uma profissão muito procurada e fácil de arrumar emprego. E hoje em dia a pessoa que não tiver } \\
\text { uma profissåo hoje no mercado de trabalho, está dificil. Então eu optei por esta profissão por que é fácil } \\
\text { arrumar serviço e também você tem que ter um estudo, você tem que ser formado na profissão. É uma } \\
\text { profissão que eu gosto de desempenhar, você está sempre conhecendo gente diferente. Você se sente mais a } \\
\text { vontade. É uma profissão que você tem que ter muita responsabilidade também. Estou gostando, porque eu } \\
\text { nunca tinha trabalhado de auxiliar de limpeza, mas estou gostando. Eu já trabalhei em várias áreas da limpeza } \\
\text { e nunca tinha trabalhado em área hospitalar ainda. Foi a primeira experiência. } \\
\text { Sujeitos: (ALI, SI, S3, AL2, AL3) }\end{array}$ & & \\
\hline
\end{tabular}

\section{DISCURSO DO SUJEITO COLETIVO}

\section{Por que optou por esta profissão /especialização?}

\begin{tabular}{|c|c|c|}
\hline $\begin{array}{c}\text { IDEIA } \\
\text { CENRALC }\end{array}$ & $\begin{array}{c}\text { Médicos (Obstetras, Neonatologistas, Anestesiologistas, } \\
\text { UTI Materno e Neonatal) }\end{array}$ & Direção do HMI e Ambulatório \\
\hline $\begin{array}{l}\text { Gosta mais de } \\
\text { Ginecologia porém } \\
\text { faz Obstetricia por } \\
\text { oportunidade de } \\
\text { trabalho }\end{array}$ & $\begin{array}{l}\text { Eu gosto mais da ginecologia. Bem mais da ginecologia. } 100 \% \\
\text { ginecologia. Eu faço plantão de obstetrícia porque aqui eu sou } \\
\text { concursada, é o único lugar que eu tenho um vínculo maior. Por isso é } \\
\text { que eu fico. Porque a obstetrícia não é uma parte que eu goste, que eu } \\
\text { me interesse. Eu gosto muito da Ginecologia, eu adoro. } \\
\text { Sujeitos: (O5) }\end{array}$ & $\begin{array}{l}\text { Eu me identifico mais com Ginecologia. Eu sou treinado nas duas especialidade, } \\
\text { tenho formação nas duas especialidades. Como eu estou ficando mais velho eu faço } \\
\text { mais gineco, porque obstetrícia cansa demais, eu não preciso acordar nas } \\
\text { madrugadas, mas eu gosto de obstetrícia. } \\
\text { Sujeitos: (DC) }\end{array}$ \\
\hline
\end{tabular}




\section{DISCURSO DO SU.JEITO COLETIVO}

\section{Por que optou por esta profissão /especialização?}

\begin{tabular}{|c|c|c|}
\hline $\begin{array}{c}\text { II)EIA } \\
\text { CINTRALI }\end{array}$ & Médicos (Obstetras, Neonatologistas, Anestesiologistas, UTI Materno e Neonatal) & Direção do HMI e Ambulatório \\
\hline $\begin{array}{l}\text { Incomodo pela } \\
\text { incompatibilidade } \\
\text { da dor das } \\
\text { parturientes e a } \\
\text { presenca do } \\
\text { recurso anestésico }\end{array}$ & $\begin{array}{l}\text { Anestesia, como o nome já está falando é a ciência que estuda a dor, é o conforto para os pacientes no } \\
\text { ato cirúrgico. Então, eu escolhi anestesia porque eu detestava ver as pacientes sofrerem nos Prontos } \\
\text { Socorros da vida, nos hospitais. Na época eu não me contentava em ver o sofrimento do ser humano, o } \\
\text { ser humano com dor, sendo que existia milhões de indicaçães ali naquele momento, naquele local e } \\
\text { ninguém as empregava. } \\
\text { Sujeitos: (A1. A2) }\end{array}$ & \\
\hline
\end{tabular}

\section{DISCURSO DO SUJEITO COLETIVO}

\section{Por que optou por esta profissão /especialização?}

\begin{tabular}{|c|c|c|}
\hline $\begin{array}{l}\text { IDEIA } \\
\text { CENTRALE }\end{array}$ & $\begin{array}{c}\text { Médicos (Obstetras, Residentes, Neonatologistas, Anestesiologistas, UTI Materno e } \\
\text { Neonatal) }\end{array}$ & Direção do HMI e Ambulatório \\
\hline $\begin{array}{l}\text { Gosta de lidar } \\
\text { com situaçōes } \\
\text { críticas }\end{array}$ & $\begin{array}{l}\text { Grande parte dos cardiologistas acabam fazendo UTI. Já estou acostumado a lidar com pacientes mais graves e } \\
\text { você acaba desenvolvendo uma personalidade para enfrentar situações críticas e saber lidar melhor com o stress. } \\
\text { Me preocupo muito com o meu semelhante. Tenho uma certa afinidade por lidar com pacientes mais criticos. } \\
\text { Sujeitos: }(11,12)\end{array}$ & \\
\hline
\end{tabular}




\section{DISCURSO DO SU.JEITO COLETIVO}

\section{Por que optou por esta profissão /especialização?}

\begin{tabular}{|c|c|c|}
\hline $\begin{array}{c}\text { UDEIA } \\
\text { CENTRALI }\end{array}$ & Médicos (Obstetras, Neonatologistas, Anestesiologistas, UTI Materno e Neonatal) & Direção do HMI e Ambulatório \\
\hline $\begin{array}{l}\text { Gosta de lidar } \\
\text { com a criança, } \\
\text { mas não com } \\
\text { sua família }\end{array}$ & $\begin{array}{l}\text { Quando eu entrei na Faculdade eu queria ser pediatra, depois no } 6^{\circ} \text { ano eu desisti e quis fazer obstetricia. Eu não sei se } \\
\text { teve uma causa, eu não vou nem te dizer que era porque eu gostava, porque eu adora, não. O meu negócio era criança, } \\
\text { mas depois que eu passei pela pediatria eu vi que não era aquilo, porque a gente não ficava só com as crianças em si, } \\
\text { era muita mãe, muita encheção e eu acabei optando por obstetrícia depois. Mas, nada no particular porque eu gostava. } \\
\text { Sujeitos: (O5) }\end{array}$ & \\
\hline
\end{tabular}

\section{DISCURSO DO SUJEITO COLETIVO}

\section{Por que optou por esta profissão lespecialização?}

\begin{tabular}{|c|c|c|}
\hline $\begin{array}{c}I D E I A \\
\text { CENTR } A L G\end{array}$ & Médicos (Obstetras, Neonatologistas, Anestesiologistas, UTI) & Direção do HMI e Ambulatório \\
\hline $\begin{array}{l}\text { Neonatologia é a } \\
\text { área da medicina } \\
\text { mais distante das } \\
\text { doencas }\end{array}$ & $\begin{array}{l}\text { O contato com os bebês para mim é muito prazeroso. Eu acho que é a parte principal da infância e é muito gostoso } \\
\text { você tirar um bebê que vai ter toda uma vida pela frente e melhorar as condições de vida para ele. Tem a urgência, } \\
\text { tem a parte bonita da medicina. É a parte mais longe da doença possível, é o nascimento. E você tem a possibilidade } \\
\text { de ter um dia-a-dia mais normal. } \\
\text { Sujeitos: (N2) }\end{array}$ & \\
\hline
\end{tabular}




\section{DISCURSO DO SU.JFITO COLETIVO}

\section{Por que optou por esta profissão /especialização?}

\begin{tabular}{|c|c|c|}
\hline $\begin{array}{c}\text { IDEIA } \\
\text { CENRAL }\end{array}$ & $\begin{array}{c}\text { Médicos (Obstetras, Neonatologistas, Anestesiologistas, UTI } \\
\text { Materno e Neonatal) }\end{array}$ & Outros profissionais da área Assistencial \\
\hline $\begin{array}{l}\text { Optou por ser } \\
\text { una tradição } \\
\text { de familia }\end{array}$ & $\begin{array}{l}\text { É uma profissão que eu me identifico muito. É uma tradição da nossa família. E } \\
\text { é uma coisa que eu me sinto muito realizado comigo também na profissão que eu } \\
\text { escolhi. } \\
\text { Sujeitos: }(\mathrm{O} 4)\end{array}$ & $\begin{array}{l}\text { A minha mãe era obstetriz e eu queria fazer obstetrícia. mas quando eu fiz o } \\
\text { curso eu não quis a área e segui na área de enfermagem. } \\
\text { Sujeitos: (E6) }\end{array}$ \\
\hline
\end{tabular}

\section{DISCURSO DO SU.JEITO COLETIVO}

\section{Por que optou por esta profissão /especialização?}

\begin{tabular}{|c|c|c|}
\hline $\begin{array}{c}\text { IDEI.4 } \\
\text { CENTRALI }\end{array}$ & Direção do HMI e Ambulatório & Profissionais da Área Administrativa \\
\hline $\begin{array}{l}\text { Nãu optou pela } \\
\text { profissão, passou no } \\
\text { concurso público }\end{array}$ & $\begin{array}{l}\text { Na verdade no serviço público você não escolhe } \\
\text { vocé é escolhido. Não existe plano de carreira. Eu } \\
\text { gosto do trabalho administrativo. } \\
\text { Sujeitos: (DU) }\end{array}$ & $\begin{array}{l}\text { Na época em que eu soube que tinham aberto concurso eu estava desempregada. então eu prestei o } \\
\text { concurso, consegui passar. Eu estava desempregada e a única opção era prestar um concurso público, e } \\
\text { eu prestei o concurso. Eu fiz um pequeno descritivo do que eu fazia antes e fui colocada aqui para } \\
\text { trabalhar no RH. Eu iniciei não aqui no Hospital Maternidade Interlagos, iniciei no Núcleo } 2 \text { e optei } \\
\text { por administraçăo, a parte administrativa por que eu me adapto mais a mexer com papeis. Então RH era } \\
\text { o que eu queria mesmo, porque eu já tinha Irabalhado cm RII em outras empresas. Eu também estava } \\
\text { procurando alguma coisa na parte de administração. E surgiu essa oportunidade e eu agarrei. Não foi } \\
\text { opção. Eu entrei porque eu prestei concurso e entrei aqui. Logo de inicio, eu não tinha muita } \\
\text { experiência aqui no hospital e na primeira e segunda semana eu já consegui me identificar um pouco no } \\
\text { serviço. É a minha cara para dizer a verdade. Eu fui escolhida, e não escolhi. } \\
\text { Sujeitos: (OA2, OA3, OA4, OA5, OAl) }\end{array}$ \\
\hline
\end{tabular}




\section{DISCURSO DO SUJFITO COLETIVO}

\section{Por que optou por esta profissão /especialização?}

\begin{tabular}{|c|c|c|c|}
\hline $\begin{array}{c}\text { IDEIA } \\
(E N T R I L J\end{array}$ & $\begin{array}{l}\text { Profissionais da área } \\
\text { Administrativa }\end{array}$ & Outros profissionais da área Assistencial & $\begin{array}{l}\text { Lideres Setoriais } \\
\text { de Acolhimento }\end{array}$ \\
\hline $\begin{array}{l}\text { Não passou no } \\
\text { vestibular de } \\
\text { medicina }\end{array}$ & & $\begin{array}{l}\text { Quando foi para eu fazer vestibular eu optei por medicina, mas nåo passei, então eu fiz enfermagem. Foi o que } \\
\text { eu passei. enfermagem. Eu fui fazer, nåo porque eu queria, foi o que eu passei no vestibular, aí comecei a } \\
\text { faculdade, e gostei. } \\
\text { Sujeitos: (E7) }\end{array}$ & \\
\hline
\end{tabular}

\section{Por que optou por esta profissão /especialização?}

\begin{tabular}{|c|c|c|c|}
\hline IDEIACENTRALK & $\begin{array}{l}\text { Profissionais da área } \\
\text { Administrativa }\end{array}$ & Outros profissionais da área Assistencial & $\begin{array}{l}\text { Líderes Setoriais } \\
\text { de Acolhimento }\end{array}$ \\
\hline $\begin{array}{l}\text { Sua história de vida } \\
\text { influenciou na sua decisãn }\end{array}$ & & $\begin{array}{l}\text { Eu escolhi enfermagem, porque eu já trabalhava na Santa Casa de Santos, e é uma forma de você } \\
\text { estar fazendo algo por alguém e, não deixar que as pessoas de repente morram no hospital; uma } \\
\text { vez que eu perdi meu pai também, nas mesmas condições. Então uma coisa foi puxando a outra } \\
\text { e você acaba na área da saúde. } \\
\text { Sujeitos (E4) }\end{array}$ & \\
\hline
\end{tabular}




\section{DISC IIRSO DO SUJEITO COLFTIVO}

\section{Você está satisfeita (o) com o que você vem desempenhando aqui? O que precisa ser melhorado?}

\begin{tabular}{|c|c|c|c|c|}
\hline \multicolumn{2}{|c|}{ CENTRALI } & \multicolumn{2}{|c|}{ Médicos (Obstetras, Residentes, Neonatologistas, Anestesiologistas, UTI Materno e Neonatal) } & \\
\hline $\begin{array}{l}\text { Está satisfeito, } \\
\text { "ão apontou po } \\
\text { serem melhor }\end{array}$ & $\begin{array}{l}\text { mas } \\
\text { antos a } \\
\text { ados }\end{array}$ & \multicolumn{2}{|c|}{$\begin{array}{l}\text { Eu estou extremamente satisfeito, mas é claro que a gente procura melhorar cada vez mais o atendimento e dar atenção para nossas } \\
\text { pacientes. Eu procuro fazer o melhor. Até agora estou satisfeito sim, é bem puxado, bastante corrido mesmo, claro que tem coisas } \\
\text { que precisam melhorar. Mas muitas coisas estão ótimas, não tem tantas queixa assim não. } \\
\text { Sujeitos: }(\mathrm{O} 4, \mathrm{~N} I, \mathrm{RB})\end{array}$} & \\
\hline \multicolumn{5}{|c|}{ foi construido com depoimentos de um obstetra, um neonatologista e um residente de obstetricia. } \\
\hline $\begin{array}{c}\text { IDEIA } \\
\text { CENTRALJ }\end{array}$ & \multicolumn{2}{|r|}{$\begin{array}{l}\text { Profissionais da área } \\
\text { Administrativa }\end{array}$} & \multicolumn{2}{|l|}{ Outros profissionais da área Assistencial } \\
\hline $\begin{array}{l}\text { Estí satisfeito, } \\
\text { mas não } \\
\text { apontou } \\
\text { pontos a serem } \\
\text { melhorados }\end{array}$ & \multicolumn{2}{|c|}{$\begin{array}{l}\text { Bom. devido o pouco tempo que eu } \\
\text { estou aqui, eu estou satisfeito. } \\
\text { Devido a gente estar lidando com o } \\
\text { público, você pode estar ajudando } \\
\text { de várias maneiras. Uma palavra } \\
\text { amiga, um apoio, alguma coisa que } \\
\text { seja útil naquele momento. Estou } \\
\text { satisfeito por este fato mesmo, dá } \\
\text { ligação entre nós e os pacientes, do } \\
\text { apoio que a gente passa para elas. A } \\
\text { gente fica satisfeito de ver como o } \\
\text { nosso trabalho está sendo produtivo. } \\
\text { Sujeitos: (S3, S2, S4) }\end{array}$} & \multicolumn{2}{|c|}{$\begin{array}{l}\text { Eu gosto desta área, embora seja uma maternidade, tem todo um enfoque da internação. Acho que é um momento muito } \\
\text { delicado na vida do ser humano, quando ele está internado, mesmo que seja para ter um bebê e ate por estar tendo um bebê. } \\
\text { Então eu acho que eu estou satisfeita. Eu acho que, não são todos, mas tem muitas pacientes que te gratificam nessa parte. } \\
\text { Atualmente, eu estou trabalhando no alojamento conjunto, que é uma área que você não tem tanto contato com a paciente, } \\
\text { mas eu digo assim na hora do parto, eu gosto de fazer parto. No trabalho de parto, você faz o parto, depois você vê a } \\
\text { gratificação da paciente com você. Porque na minha opinião, a paciente que está em trabalho de parto, ela está muito frágil, } \\
\text { então de repente a atenção que você dá para ela, quando termina o parto ela te gratifica. Mas, eu gosto desse trabalho, e aqui } \\
\text { também no alojamento conjunto é bom também. Eu estou muito satisfeita. Estou desempenhando uma coisa boa. Eu faço o } \\
\text { período da tarde e eu trabalho com o Alojamento Materno e eu gosto muito desta área. Eu tenho podido ajudar as mãezinhas a } \\
\text { aleitar os seus bebês. Gosto muito do que eu faço. Toda pessoa quando faz o que gosta, ela dá o melhor de si. Ela faz tudo } \\
\text { para fazer o melhor. Eu creio que todo mundo está satisfeito com o meu trabalho, pelo menos é o que eu entendo e eu também } \\
\text { me sinto muito satisfeita com o que eu faço. Procuro fazer sempre o melhor. Eu faço o que eu gosto, não tenho problemas } \\
\text { nenhum, nem com chefia, nem com ninguém. Então, eu não tenho reclamações. Estou satisfeita aqui. } \\
\text { Sujeitos: (PI, E7, AE1, E6, AE2, TL, Fl) }\end{array}$} \\
\hline
\end{tabular}
farmacêutico. 


\section{DISCURSO DO SUJEITO COLETIVO}

Você está satisfeita (o) com o que você vem desempenhando aqui? O que precisa ser melhorado?

\begin{tabular}{|c|c|c|}
\hline $\begin{array}{c}I D E L A \\
C E N T R A L K\end{array}$ & Médicos (Obstetras, Residentes, Neonatologistas, Anestesiologistas, UTI Materno e Neonatal) & $\begin{array}{c}\text { Direção do HMI e } \\
\text { Ambulatório }\end{array}$ \\
\hline $\begin{array}{l}\text { stá satisfeito por } \\
\text { ter vinculos } \\
\text { tisfatórios com a } \\
\text { instituição }\end{array}$ & $\begin{array}{l}\text { Hoje eu me sinto satisfeita. Hoje eu já estou do outro lado da moeda, não sou mais a plantonista do hospital somente. } \\
\text { Muitas vezes eu só vinha prestar um trabalho naquele dia, acabou o plantão e você não tem mais vínculo. Eu já tenho } \\
\text { vínculo com tudo, com todos os profissionais do hospital e da parte administrativa. Então, hoje eu acho que eu faço } \\
\text { muito mais do que antigamente. } \\
\text { Sujeitos: (OI) }\end{array}$ & \\
\hline
\end{tabular}




\section{DISCIRSO DO SUJEITO COLETIVO}

\section{O que você entende por Humanização da Assistência Materno-Neonatal?}

\begin{tabular}{|c|c|c|}
\hline $\begin{array}{l}\text { IDEIA } \\
\text { CENTRALH }\end{array}$ & $\begin{array}{l}\text { Médicos (Obstetras, Residentes, Neonatologistas, Anestesiologistas, } \\
\text { UTI Materno e Neonatal) }\end{array}$ & Direção do HMI e Ambulatório \\
\hline $\begin{array}{l}\text { Tratar a } \\
\text { pacicnte com } \\
\text { dignidade, } \\
\text { apoia-la en } \\
\text { todas as } \\
\text { circunstancias, } \\
\text { respcitando } \\
\text { todas suas } \\
\text { caracteristicas }\end{array}$ & 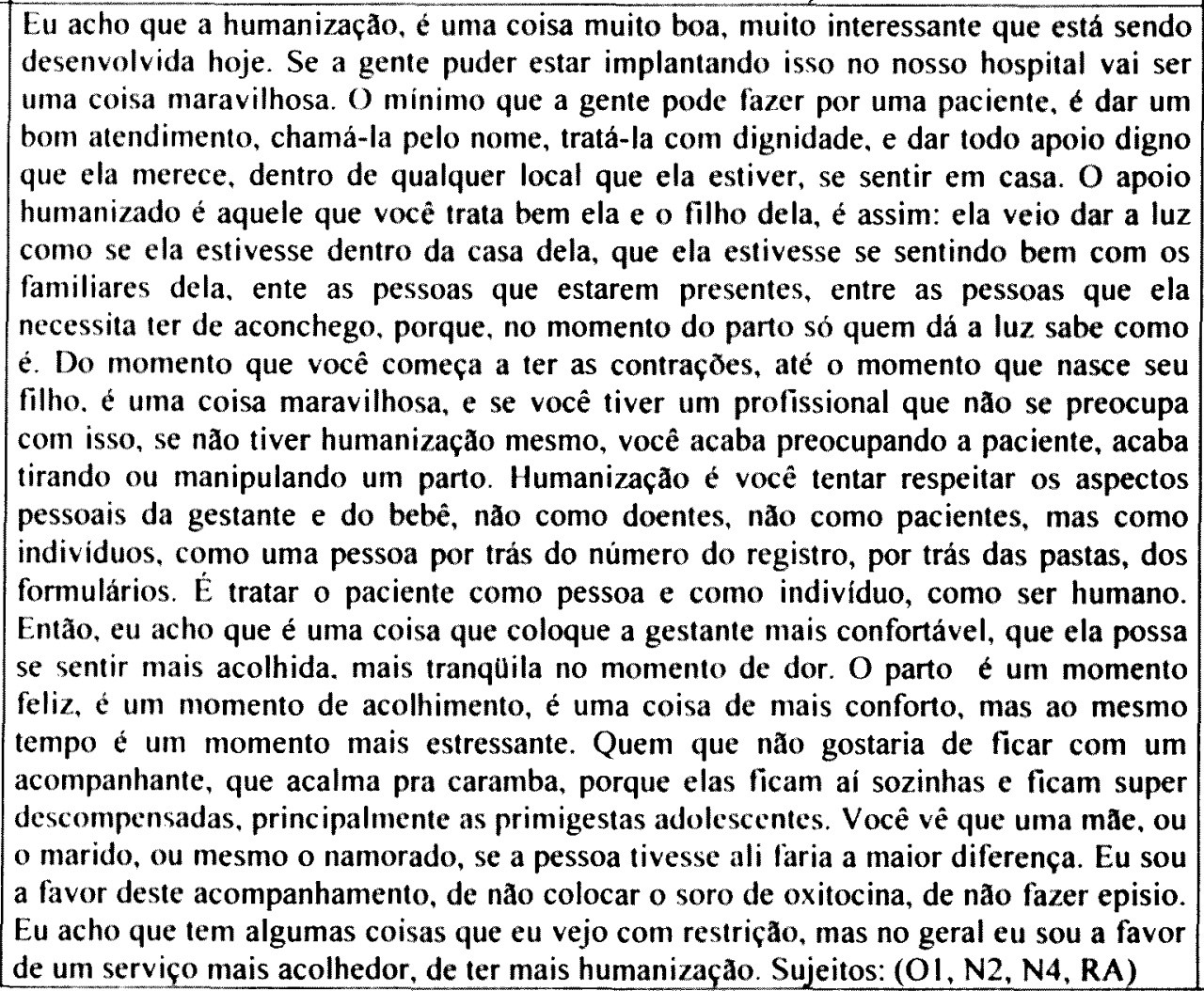 & 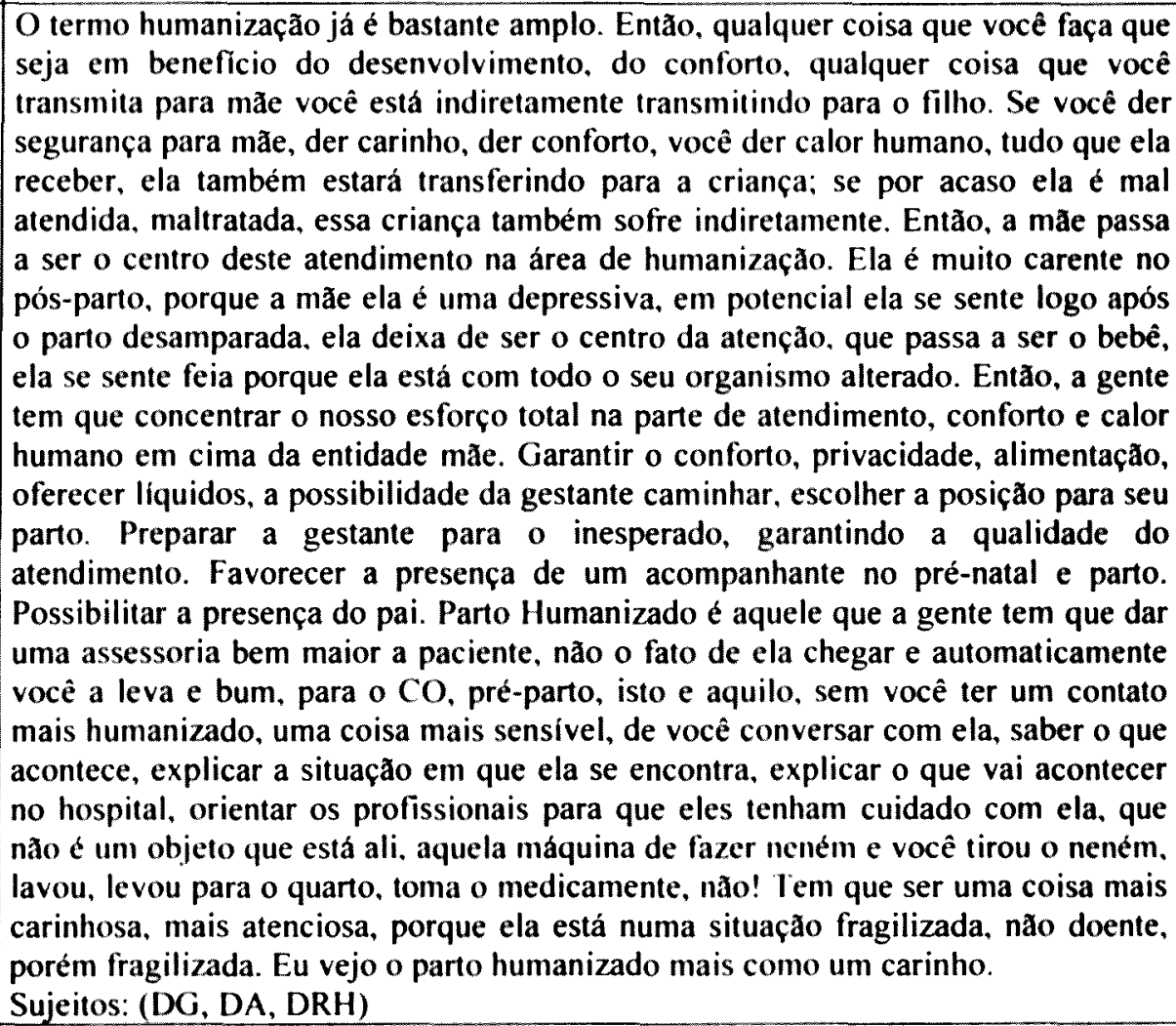 \\
\hline
\end{tabular}

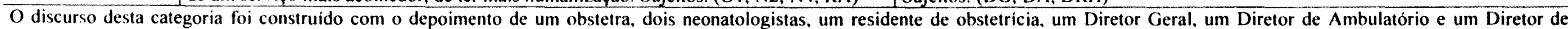

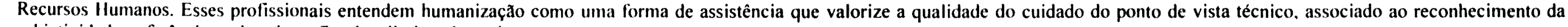
subjetividade. referências culturais. enfim dos direitos da paciente. 


\section{DISCURSO DO SUJEITO COLETIVO}

\section{O que você entende por Humanização da Assistência Materno-Neonatal?}

\begin{tabular}{|c|c|c|c|}
\hline $\begin{array}{c}\text { IDEI } \\
C E N T R A L I\end{array}$ & $\begin{array}{l}\text { Profissionais da área } \\
\text { Administrativa }\end{array}$ & Outros profissionais da área Assistencial & $\begin{array}{l}\text { Líderes Setoriais } \\
\text { de Acolhimento }\end{array}$ \\
\hline $\begin{array}{l}\text { Tratar a } \\
\text { paciente com } \\
\text { dignidade, } \\
\text { apoia-la em } \\
\text { todas as } \\
\text { circunstâncias. } \\
\text { respeitando } \\
\text { todas suas } \\
\text { caracteristicas }\end{array}$ & & 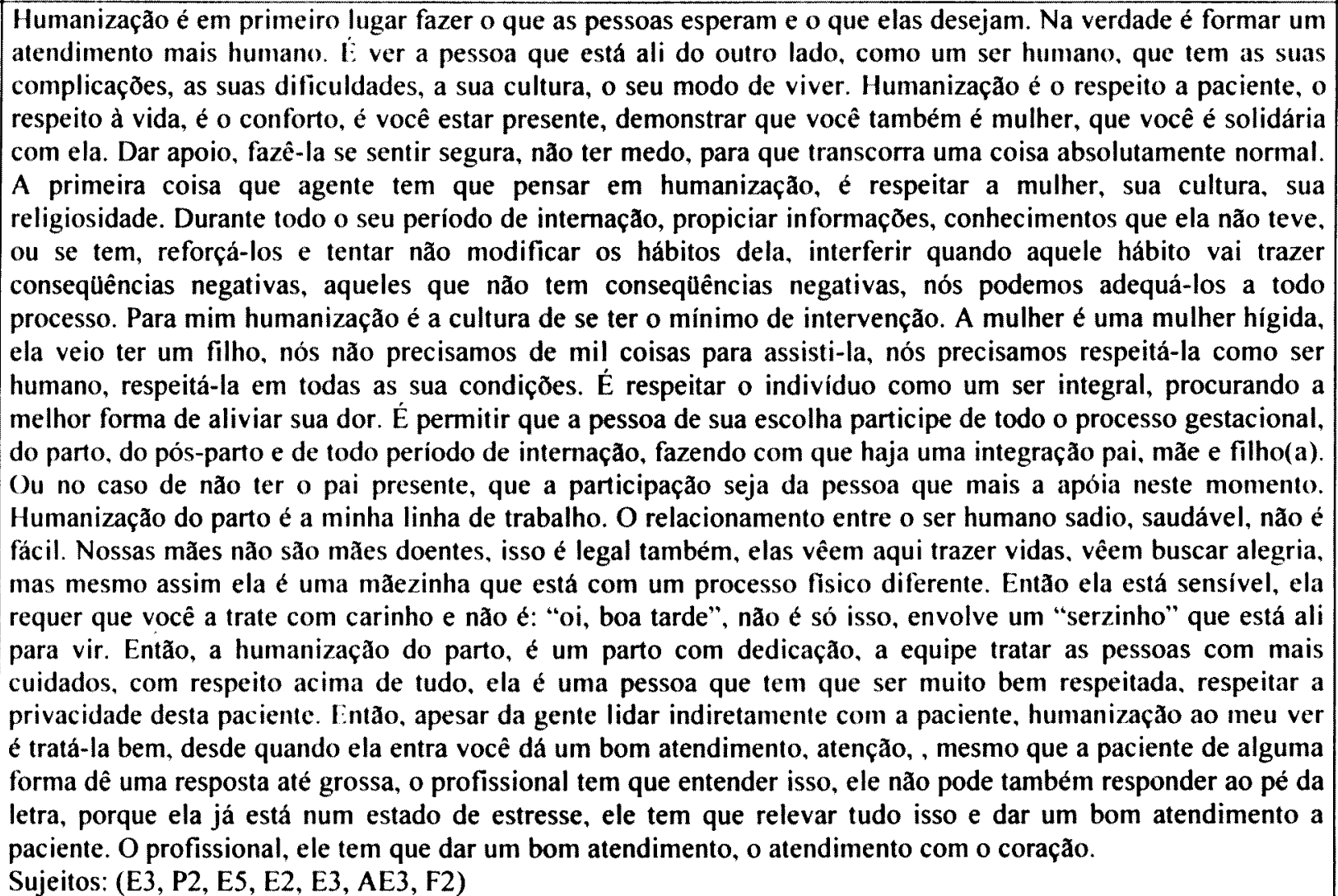 & \\
\hline
\end{tabular}




\section{DISCIRSO DO SUJFITO COLETIVO}

\section{O que você entende por Humanização da Assistência Materno-Neonatal?}

\begin{tabular}{|c|c|c|}
\hline $\begin{array}{c}\text { IDIIA } \\
\text { CENTRILJ }\end{array}$ & Médicos (Obstetras, Residentes, Neonatologistas, Anestesiologistas, UTI Materno e Neonatal) & Direção do HMI e Ambulatório \\
\hline $\begin{array}{l}\text { Finvolvimcnto } \\
\text { não si dos } \\
\text { profissionais e } \\
\text { da } \\
\text { administração } \\
\text { como também } \\
\text { do usuário }\end{array}$ & $\begin{array}{l}\text { No parto humanizado, você tem que ser humano no parto, humano no aspecto de relacionamento. Então, a paciente } \\
\text { primeiro ela tem que entender o que é o parto humanizado, o paciente, não é só os profissionais envolvidos, e desta } \\
\text { integração entre o paciente e os profissionais envolvidos, médico, enfermeiro a própria administração do hospital, tem } \\
\text { que estar bem integrada, bem trabalhada, como se fosse um relógio, para poder não ter suas falhas. Humanização começa } \\
\text { desde a porta de entrada. É talvez conceder a este grupo de pessoas que serão subestimadas ao atendimento, um ambiente } \\
\text { mais acolhedor, onde a compreensão e a preocupação com o doente seja o primeiro objetivo que deve ser atingido e que } \\
\text { tem que estar acima dos procedimentos em si. Para humanizar o hospital deve começar pela admissão do doente aqui. } \\
\text { Sujeitos: }(\mathrm{O} 2, \mathrm{II})\end{array}$ & $\begin{array}{l}\text { Os profissionais envolvidos deverão } \\
\text { evitar procedimentos invasivos, } \\
\text { dolorosos e desnecessários, atualmente } \\
\text { não mais indicados cientificamente, } \\
\text { como por exemplo a raspagem de pelos, } \\
\text { episiotomia, etc. } \\
\text { Sujeitos: (DA) }\end{array}$ \\
\hline
\end{tabular}

O discurso desta categoria foi construido com depoimentos de um obstetra e um intensivista.

\begin{tabular}{|c|c|c|}
\hline $\begin{array}{c}I D E I A \\
\text { CENTRALK }\end{array}$ & Médicos (Obstetras, Residentes, Neonatologistas, Anestesiologistas, UTI Materno e Neonatal) & $\begin{array}{c}\text { Direçāo do HMI e } \\
\text { Ambulatório }\end{array}$ \\
\hline $\begin{array}{l}\text { O despreparo } \\
\text { da população } \\
\text { difículta o } \\
\text { processo de } \\
\text { Humanização } \\
\text { da Assistência }\end{array}$ & $\begin{array}{l}\text { Eu não sei se o nosso povo tem a educação para entrar nesse esquema do parto humanizado, eu sinceramente acho que não. As } \\
\text { mulheres pacientes, porque os profissionais você vai mudar algumas coisas, você vai dar uma palestra e fala: "olha daqui para frente } \\
\text { você vai ser assim", acredito que em um mês, dois, três nós vamos entrar no ritmo. Mas, eu acho que a população não tem uma } \\
\text { educação, não tem um entendimento sobre o parto humanizado. As mulheres falam que querem parto normal da boca para fora, } \\
\text { porque na hora que elas estão na cama gemendo de dor, você pode subir ali e todas querem cesárea, dizem que querem cesárea } \\
\text { agora. A gestante no transcorrer do pré-natal ela tem que ser educada para o parto normal. Porque todas que disseram que queriam } \\
\text { parto normal eu tenho certeza que estavam fora de trabalho de parto. Então, a realidade é uma fora do trabalho de parto e no trabalho } \\
\text { de parto a realidade é outra, totalmente diferente. } \\
\text { Sujeitos: }(\mathrm{O} 5,12, \mathrm{O} 2)\end{array}$ & \\
\hline
\end{tabular}

O discurso desta categoria foi construido com depoimentos de dois obstetras e um intensivista. A cultura da cesárea está muito forte entre a comunidade. 


\section{DISC IRSO DO SUJEITO COLETIVO}

\section{Cite itens de humanização neste hospital.}

\begin{tabular}{|c|c|c|}
\hline $\begin{array}{c}\text { II)IIA } \\
\text { CENTRALE }\end{array}$ & $\begin{array}{l}\text { Profissionais da área } \\
\text { Administrativa }\end{array}$ & Outros profissionais da área Assistencial \\
\hline $\begin{array}{l}\text { Implantação } \\
\text { de algumas } \\
\text { ações de } \\
\text { Humanizaçio } \\
\text { da Assistência } \\
\text { Materno- } \\
\text { Neonatal e } \\
\text { abolição de } \\
\text { condutas } \\
\text { proscritas pela } \\
\text { OMS e } \\
\text { Ministério da } \\
\text { Saúde }\end{array}$ & 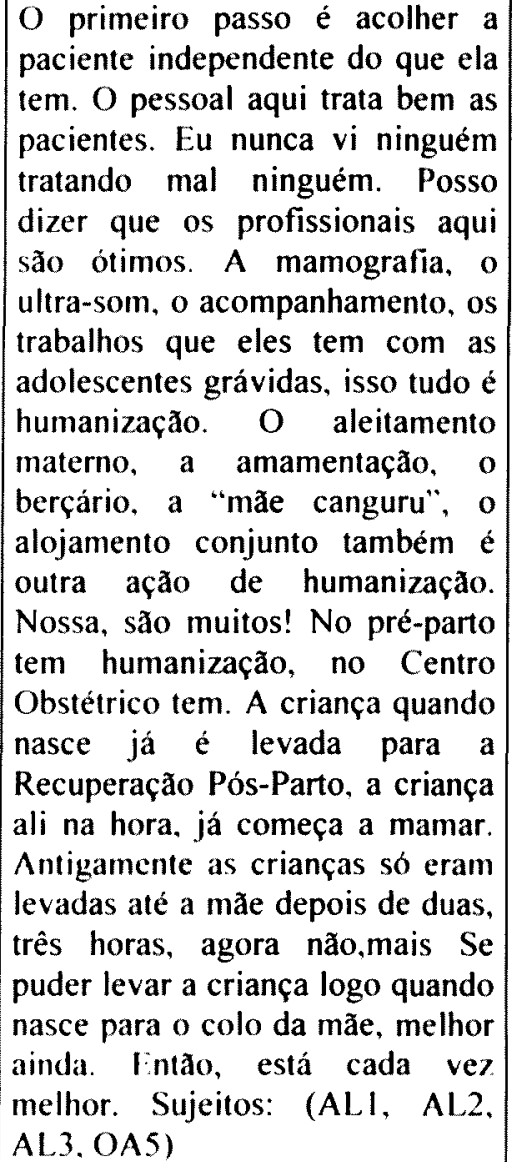 & 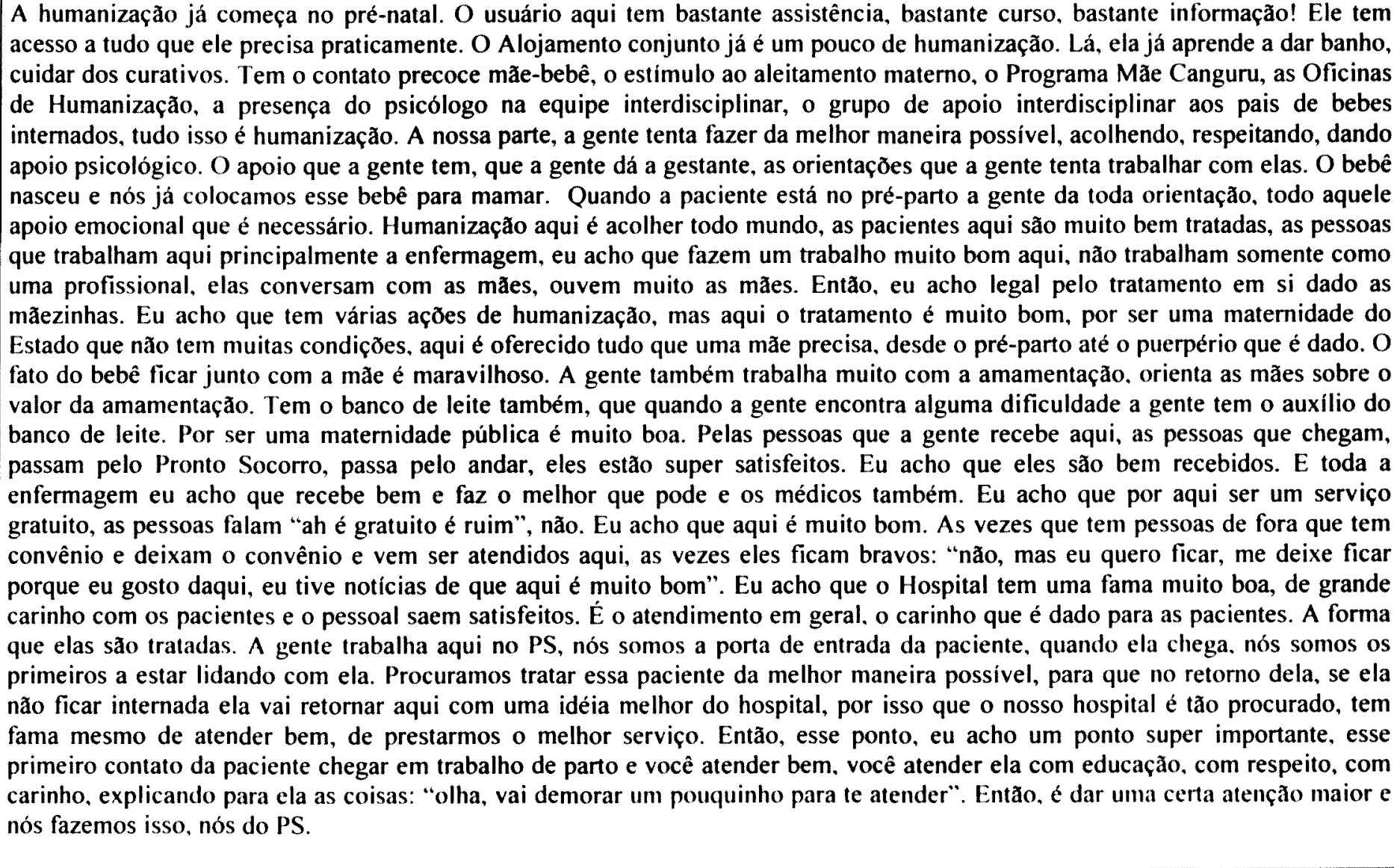 \\
\hline
\end{tabular}




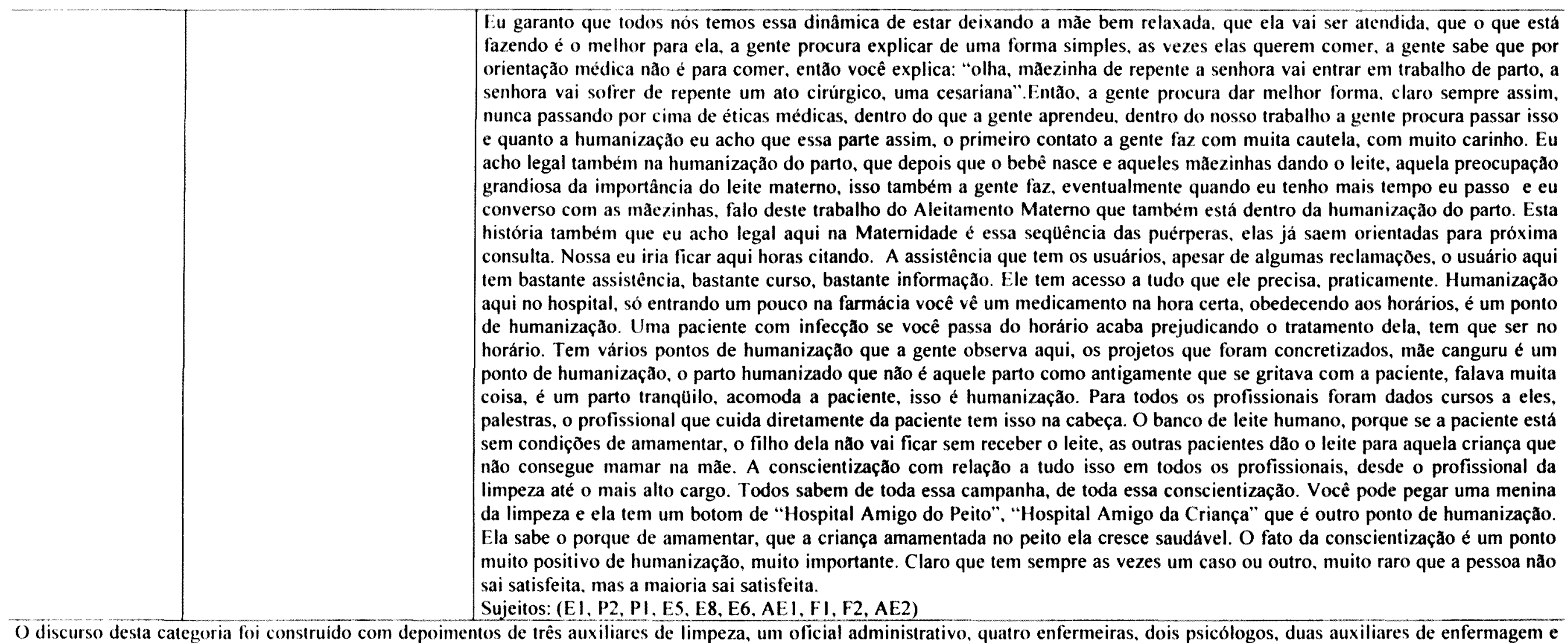
um farmacêutico. 


\section{DISCURSO DO SU,JEITO COLETIVO}

\section{Cire itens de humanização neste hospital.}

\begin{tabular}{|c|c|c|c|}
\hline $\begin{array}{l}\text { IIIIA } \\
\text { CINTRILI }\end{array}$ & $\begin{array}{l}\text { Médicos (Obstetras, Residentes, Neonatologistas, } \\
\text { Anestesiologistas, UTI Materno e Neonatal) }\end{array}$ & Direção do HMI e Ambulatório & $\begin{array}{c}\text { Outros profissionais da Área } \\
\text { Assistencial }\end{array}$ \\
\hline $\begin{array}{l}\text { Alualmente parte } \\
\text { dos profissionais } \\
\text { jí estão } \\
\text { sensibilizados/ } \\
\text { capacitados para } \\
\text { assistência } \\
\text { humanizada }\end{array}$ & $\begin{array}{l}\text { Pontos de humanização eu vejo vários. Os próprios profissionais } \\
\text { trabalham numa estrutura que você precisa prepará-los para poder fazer } \\
\text { a humanizaçåo do parto, nåo é querer fazer parto humanizado, primeiro } \\
\text { precisa preparar as equipes, preparar os profissionais envolvidos para } \\
\text { que possam dar bom atendimento nesse aspecto de humanização ao } \\
\text { parto e os profissionais aqui eståo sendo preparados. O atendimento a } \\
\text { paciente está cada dia melhorando. As pessoas aqui såo muito humanas, } \\
\text { os funcionários aqui tratam bem as gestantes, a parte da enfermagem é } \\
\text { bem orientada da parte de aleitamento, todo mundo orienta bem aqui, } \\
\text { tanto no pré-parto quanto nas enfermarias, tanto no puerpério imediato } \\
\text { quanto no pré-natal. A parte humana é boa aqui. as pessoas em si e o } \\
\text { treinamento dos funcionários é bom. } \\
\text { Sujeitos: (O2, RA) }\end{array}$ & $\begin{array}{l}\text { Todo local a gente sabe que tem } \\
\text { profissionais que vestem a camisa e } \\
\text { profissionais que nåo vestem. então tem } \\
\text { setores que tem pessoas que realmente } \\
\text { lidam com essa parte de humanização, } \\
\text { tratam a pessoa como ela merece, com o } \\
\text { cuidado que ela merece, como se } \\
\text { estivessem se colocando no lugar dela e } \\
\text { tem pessoas que nåo cumprem isso, } \\
\text { acha que é uma máquina que está ali e } \\
\text { você tira o neném acabou e pronto, vem } \\
\text { a próxima e vem a próxima. } \\
\text { Sujeitos: (DRH) }\end{array}$ & $\begin{array}{l}\text { Várias pessoas já estâo voltadas para esta } \\
\text { queståo da humanizaçăo. a queståo de respeito, } \\
\text { e outras pessoas para essa questão de } \\
\text { intervencionista dentre de si, a questão cultural } \\
\text { mesmo. Isto que nós precisamos melhorar, } \\
\text { várias intervençóes.que alguns ainda } \\
\text { continuam utilizando, que não devem utilizar, } \\
\text { que é hinema, a ocitocina, a tricotomiase, etc. } \\
\text { E isto precisa ser muito mudado. } \\
\text { Sujeitos: (E2) }\end{array}$ \\
\hline
\end{tabular}

O discurso desta categoria foi construído com depoimentos de um obstetra, um residente de obstetricia, um Diretor de Recursos Humanos e uma enfermeira. 


\section{DISCURSO DO SUJEITO COLETIVO}

\section{Cite itens de humanização neste hospital.}

\begin{tabular}{|c|c|c|c|}
\hline $\begin{array}{c}\text { IDÉIA } \\
\text { CENTRALG }\end{array}$ & $\begin{array}{l}\text { Médicos (Obstetras, Residentes, } \\
\text { Neonatologistas, A nestesiologistas, } \\
\text { UTI Materno e Neonatal) }\end{array}$ & $\begin{array}{l}\text { Outros } \\
\text { profissionais da } \\
\text { Area Assistencial }\end{array}$ & Lideres Setoriais de Acolhimento \\
\hline $\begin{array}{l}\text { A instituição tem } \\
\text { mais pontos de } \\
\text { desumanização do } \\
\text { que de humanização }\end{array}$ & $\begin{array}{l}\text { Aqui tem mais pontos de desumanizaçåo } \\
\text { do que de humanizaçåo. Mas a gente nåo } \\
\text { pode generalizar, porque a gente tem } \\
\text { pessoas que se dedicam muito aqui. } \\
\text { Sujeitos: (O1) }\end{array}$ & $\begin{array}{l}\text { Humanizaçăo aqui } \\
\text { neste hospital, está um } \\
\text { pouco dificil, pela área } \\
\text { fisica. Ainda deixa a } \\
\text { desejar a humanização } \\
\text { aqui. A gente não } \\
\text { pode receber os } \\
\text { parentes da paciente, } \\
\text { porque a planta fisica } \\
\text { não permite. } \\
\text { Sujeitos: (E7, E5) }\end{array}$ & $\begin{array}{l}\text { A Enfermeira aplica advertência, alegando reclamação de paciente, sendo que ao } \\
\text { solicitar a cópia na ouvidoria, a reclamação não existia, nada foi feito, porém, a } \\
\text { advertência foi aplicada e o prêmio incentivo foi afetado. Contratado aqui é tratado } \\
\text { como cachorro. O pessoal contratado é mais descriminado pela chefia e colegas de } \\
\text { trabalho e ainda pegam no pé, falam que não vai ser renovado o contrato. Acho que os } \\
\text { funcionários do HMI recebem uma explicação oficial da Secretaria Estadual de Saúde, } \\
\text { sobre não sair o código da Maternidade e do Hospital Regional Sul para o concurso dos } \\
\text { auxiliares de enfermagem e sabemos que há vagas para a categoria. Enfermeiras recém } \\
\text { formadas que entram na profissão sem concurso ficam querendo descontar sua raiva do } \\
\text { dia-a-dia nos funcionários. Enfermeiras que sabem até menos que auxiliares antigas. } \\
\text { Falta de companheirismo. Tratamento diferenciado por parte da chefia. Falta de } \\
\text { material. Falta de espaço. Internação maior que a capacidade do pré-parto. Falta de } \\
\text { cooperação dos colegas a respeito do horário e serviço. Médicos que demoram para } \\
\text { descer para atender o cliente. Educaçăo continuada do HMI precisa ser mais presente } \\
\text { no treinamento em serviço dos funcionários. }\end{array}$ \\
\hline
\end{tabular}




\section{DISCURSO DO SUIEITO COLETIVO}

\section{Cite itens de humanização neste hospital.}

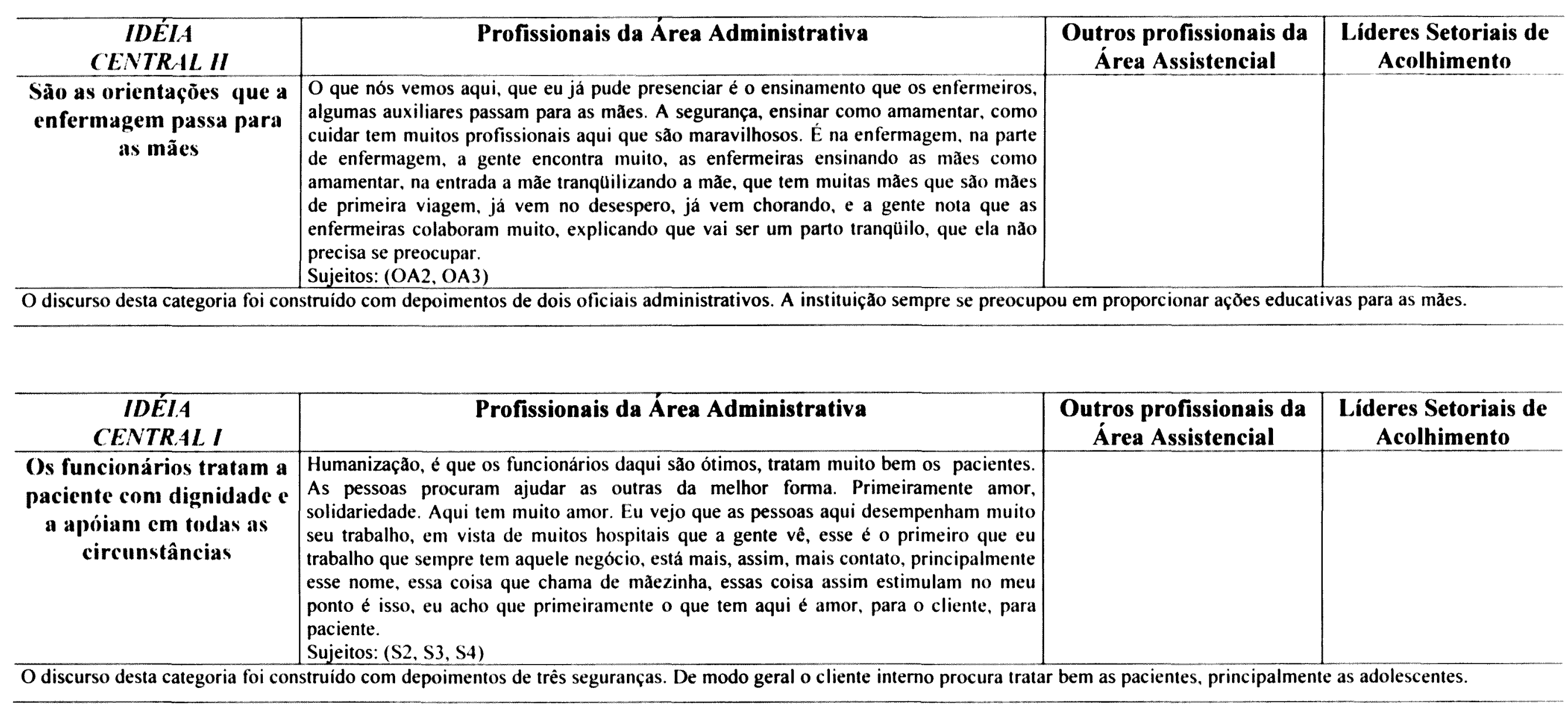




\section{DISCURSO DO SUJEITO COI.FIVO}

\section{Cite itens de desumanização neste hospital.}

\begin{tabular}{|c|c|c|c|}
\hline $\begin{array}{c}\text { IDEIA } \\
\text { CENTRALF }\end{array}$ & $\begin{array}{c}\text { Direção do HMI e } \\
\text { Ambulatório }\end{array}$ & Outros Profissionais da Área Assistencial & $\begin{array}{l}\text { Profissionais da Área } \\
\text { Administrativa }\end{array}$ \\
\hline $\begin{array}{l}\text { O espaço físico } \\
\text { de modo geral } \\
\text { é inadequado }\end{array}$ & $\begin{array}{l}\text { grande fator de } \\
\text { desumanização é o espaço } \\
\text { fisico. Se você não tem espaço } \\
\text { para acolher os familiares, o } \\
\text { marido na sala de parto, se você } \\
\text { não tem espaço para fazer uma } \\
\text { sala de acolhimento adequada, } \\
\text { se não tem área fisica para } \\
\text { poder acomodar as pacientes no } \\
\text { pós-parto, você vai limitar } \\
\text { bastante esse tipor de } \\
\text { atendimento. } \\
\text { Sujeitos: (DU, DC) }\end{array}$ & 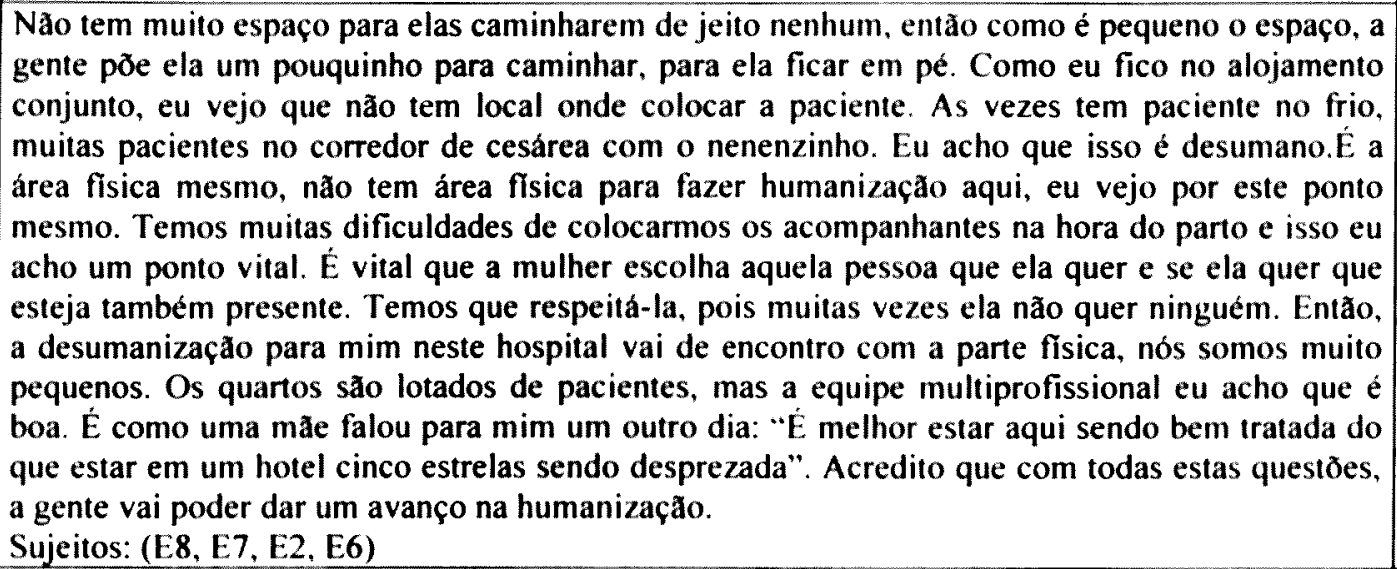 & \\
\hline
\end{tabular}




\section{DISCURSO DO SUJEITO COLETIVO \\ Cite itens de desumanização neste hospital.}

\begin{tabular}{|c|c|c|c|c|}
\hline $\begin{array}{c}\text { IDÉIA } \\
\text { CENTR.1LG }\end{array}$ & Direção do HMI e Ambulatório & $\begin{array}{c}\text { Profissionais da Área } \\
\text { Administrativa }\end{array}$ & $\begin{array}{c}\text { Outros Profissionais da } \\
\text { Área Assistencial }\end{array}$ & $\begin{array}{l}\text { Lideres Setoriais de } \\
\text { Acolhimento }\end{array}$ \\
\hline $\begin{array}{c}\text { As condiçòes } \\
\text { estruturais } \\
\text { (equipamentos } \\
\text { insuficientes e } \\
\text { deficientes, } \\
\text { superlotação) } \\
\text { do hospital, } \\
\text { não propicia } \\
\text { motivação } \\
\text { para o parto } \\
\text { humanizado }\end{array}$ & 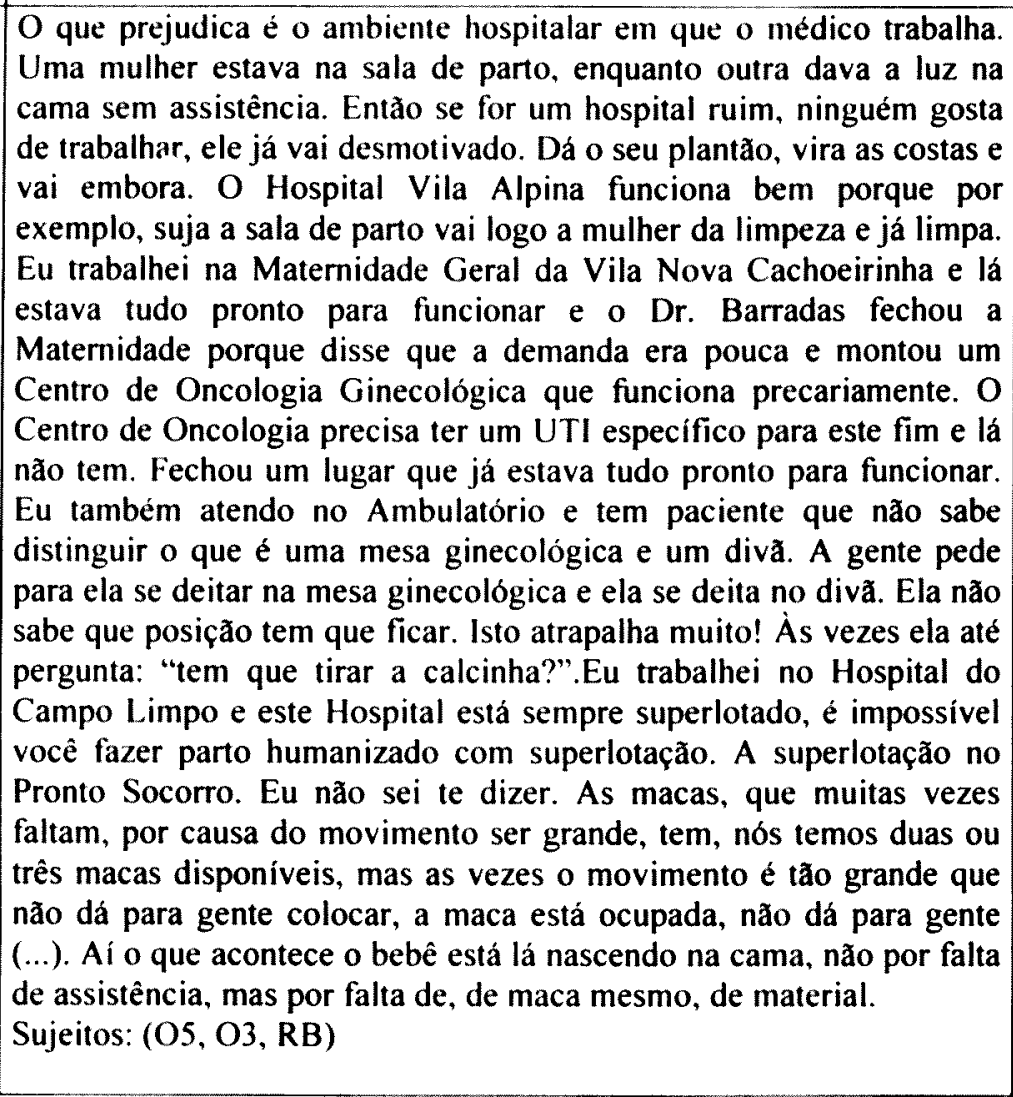 & $\begin{array}{l}\text { O elevador. As mãezinhas } \\
\text { de cesariana, querem subir } \\
\text { logo para ver o bebê no } \\
\text { berçário, elas têm que } \\
\text { subir pela escada. Algumas } \\
\text { até tem que parar degrau } \\
\text { por degrau, respirar fundo } \\
\text { para continuar subindo. } \\
\text { Então eu acho que isso è } \\
\text { desumanização. Eu acho } \\
\text { desumano os velhinhos } \\
\text { subirem as escadas. E tem } \\
\text { também deficientes. É não } \\
\text { tem elevador e as vezes } \\
\text { eles precisam subir até } \\
\text { aqui. As vezes precisa } \\
\text { alguém carregar. } \\
\text { Sujeitos: (S2, ALL) }\end{array}$ & $\begin{array}{l}\text { Não dá para fazer aquela coisa, } \\
\text { porque infelizmente falta muita } \\
\text { coisa aqui. Mas o que tem a gente } \\
\text { trabalha. O banho, a gente dá, nós } \\
\text { não temos a banheira, não temos } \\
\text { bola, mas a gente tem o nosso } \\
\text { chuveirinho, a nossa cadeirinha, e } \\
\text { a gente tenta trabalhar da melhor } \\
\text { maneira possivel. A gente não } \\
\text { tem um material legal, para } \\
\text { deixar ela de cócoras, então a } \\
\text { gente orienta como que ela fica. } \\
\text { Enfim, dar-se um jeitinho, mas } \\
\text { assim, material, planta fisica } \\
\text { infelizmente falta. Eu não digo } \\
\text { total, mas eu acho assim meio, } \\
\text { desconfortável, quando está } \\
\text { superlotado a maternidade e as } \\
\text { mães têm que ficar na maca por } \\
\text { um tempo até surgir vaga no } \\
\text { quarto, para poder voltar para } \\
\text { cama. Que as vezes na maca, fica, } \\
\text { sem poder amamentar o neném } \\
\text { direito, sem poder virar. Isso eu } \\
\text { acho desumano é bem } \\
\text { desconfortável. } \\
\text { Sujeitos: (E8, AE I) }\end{array}$ & 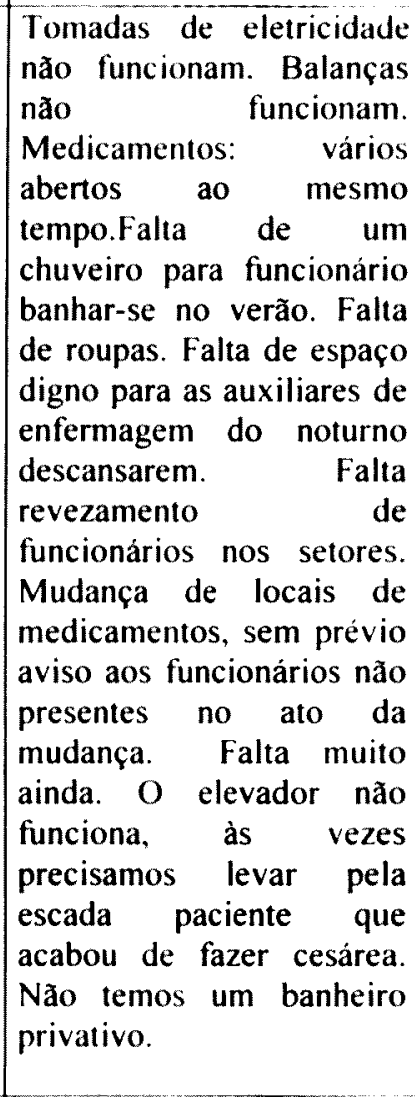 \\
\hline
\end{tabular}

O discurso desta categoria foi construído com depoimentos de dois obstetras, um residente de obstetrícia, um segurança, um auxiliar de limpeza, uma enfermeira, um auxiliar de enfermagem e Lideres Setoriais de Acolhimento. 


\section{DISCURSO DO SUJEITO COLETIVO}

Cite itens de desumanização neste hospital.

\begin{tabular}{|c|c|c|c|}
\hline $\begin{array}{c}I D E I A \\
C E N T R A L H\end{array}$ & \begin{tabular}{|c|} 
Médicos (Obstetras, Residentes, \\
Neonatologistas, Anestesiologistas, \\
UTI Materno e Neonatal)
\end{tabular} & Profissionais da Área Administrativa & Outros Profissionais da Área Assistencial \\
\hline $\begin{array}{l}\text { Não vêpontos } \\
\text { de } \\
\text { desumanização } \\
\text { no hospital }\end{array}$ & $\begin{array}{l}\text { Eu nåo vejo desumanização nesse } \\
\text { hospital, nesse objetivo. Eu não vejo } \\
\text { desumanização. Eu não percebi nenhum } \\
\text { ponto, em especial, mas talvez eu não } \\
\text { tenha percebido ainda. Porque eu estou } \\
\text { aqui há } 5 \text { meses, mas humanização eu } \\
\text { reparei, mas desumanização ainda não. } \\
\text { Sujeitos: }(\mathrm{O} 2, \mathrm{O} 5, \mathrm{~N} 1)\end{array}$ & $\begin{array}{l}\text { Acontecimentos acontecem em todos os } \\
\text { hospitais, isso ai a gente não está livre disso. } \\
\text { Mas, por enquanto eu não tenho, uma, uma } \\
\text { formalidade, eu acho que aqui, para mim é ótimo. } \\
\text { Em vista de muitos hospitais aqui esta 100\%. } \\
\text { Sempre tem que estar melhorando. Melhorando, } \\
\text { investir mais na área de enfermagem, investir } \\
\text { mais na aparelhagem. As pacientes terem mais } \\
\text { conforto. Mas de resto acho que ta um bom } \\
\text { padrão. Em vista de muitos hospitais particulares, } \\
\text { aqui está um bom padrão. Nós na área de } \\
\text { segurança que temos contato diretamente com o } \\
\text { povo, com o público, a gente sempre fica } \\
\text { sabendo. O hospital é ótimo. Em todo lugar tem } \\
\text { que estar arrumando. Não, isso aí eu nunca vi } \\
\text { nada, nunca vi assim nada errado. Se eu visse eu } \\
\text { não iria deixar de falar. Críticas mesmo, de falar, } \\
\text { "olha, tem isso esta errado", isso que faz mudar, a } \\
\text { gente crescer. Por isso, que hoje temos o apoio ao } \\
\text { usuário, por isso que temos tantas coisas boas. Se } \\
\text { eu fosse uma usuária, uma coisa que eu ficaria } \\
\text { muito triste é eu chegar no hospital, ser internada } \\
\text { e eu ser removida, mas isso eu não considero } \\
\text { desumano. Eu não vejo nada de errado, que seja } \\
\text { desumano aqui neste hospital. Não vejo mesmo. } \\
\text { Sujeitos: (S4, AL2, AL3, OA5) }\end{array}$ & $\begin{array}{l}\text { Eu acho que aqui não tem não. Aqui os faxineiros, os auxiliares, eu } \\
\text { acho que aqui todo mundo recepciona bem, os funcionários tratam } \\
\text { bem, tem um carinho. Assim que o pessoal chegam tratam bem. O } \\
\text { cliente que se diz assim agora, não é mais paciente, ele quer ser bem } \\
\text { recebido e ele é bem recebido. Ele sobe, ele tem toda atenção desde } \\
\text { aqui, no Centro Cirúrgico, no Pré-Parto. Enfim, todo mundo trabalha } \\
\text { em conjunto. Eu acho que aqui a equipe é muito boa, eu acho, pelo } \\
\text { que a gente está aqui dentro a gente vê. A idéia de todo mundo que } \\
\text { trabalha neste Hospital é não ter, estar levando um rótulo de } \\
\text { desumanização, é uma palavra que ainda existe no nosso vocabulário, } \\
\text { mas muito pelo contrário nosso trabalho é um trabalho voltado, é um } \\
\text { trabalho sério, uma preocupação grande pelo melhor atendimento, o } \\
\text { respeito. Enfim, é baseado nisso. Então, pontos de desumanização eu } \\
\text { desconheço. Olha, sinceramente, te juro, eu estou sendo muito } \\
\text { sincera. Das pessoas falarem assim: "nossa que desumano!". A única } \\
\text { coisa que as vezes a gente fica assim, porque a gente trabalha aqui no } \\
\text { PS, a gente gostaria que todas as mãezinhas que viessem para cá em } \\
\text { trabalho de parto ficasse aqui. Mas, a demanda é muito grande, não é } \\
\text { que é desumano ela ser transferida para um Hospital tão bom quanto } \\
\text { este, mas assim é que você fica chateada, poxa. A própria mãezinha } \\
\text { fala: "ah enfermeira, ah por favor fala com o médico", porque elas } \\
\text { pensam que depende da gente e não depende nem do médico para } \\
\text { elas ficarem aqui. Então, realmente você fica penalizada pela } \\
\text { situação, mas desumano, olha sinceramente, sinceramente, eu não } \\
\text { vejo, na minha equipe, aqui, eu não vejo nada que identificasse } \\
\text { desumano. } \\
\text { Sujeitos: (AE2, AE3) }\end{array}$ \\
\hline
\end{tabular}

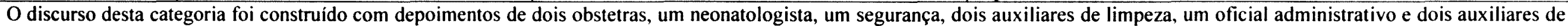
enfermagem. 


\section{DISCURSO DO SUJEITO COLETIVO}

\section{Cite itens de desumanização neste hospital.}

\begin{tabular}{|c|c|c|}
\hline $\begin{array}{c}\text { IDEIA } \\
\text { CENTRALI }\end{array}$ & $\begin{array}{l}\text { Médicos (Obstetras, Residentes, Neonatologistas, Anestesiologistas, UTI } \\
\text { Materno e Neonatal) }\end{array}$ & Outros Profissionais da Área Assistencial \\
\hline $\begin{array}{l}\text { Admissão de } \\
\text { grande volume } \\
\text { de parturientes } \\
\text { despreparadas } \\
\text { para o parto } \\
\text { normal }\end{array}$ & $\begin{array}{l}\text { A paciente vem para o cá sem orientação que deveria ser dada no pré-natal e isto aí cria um pouco } \\
\text { de insegurança na paciente, ela fica sem saber o que vai acontecer com ela. Para se ter } \\
\text { acompanhante cai naquilo que eu falei da educação, a gente sabe que até para a paciente seria a } \\
\text { melhor coisa ter um acompanhante, seja ele quem for. Mas, eu acho que o nosso povo não é } \\
\text { educado para isso, porque para gente fica extremamente dificil porque daí a gente ia ter a paciente } \\
\text { e mais o acompanhante para tomar conta, para explicar, para enfim. Para o profissional de saude } \\
\text { fica muito mais dificil, a não ser que tivesse todo um aporte antes destas duas pessoas chegarem ao } \\
\text { hospital, ter um preparo. Em uma dor que a paciente sentir o marido se descompensar, então quer } \\
\text { dizer que. E esta paciente também ser educada, porque tem paciente que sente uma dorzinha, faz } \\
\text { um escândalo desse tamanho e daí vai virar uma grande festa o negócio. Então, eu acho que para } \\
\text { paciente seria a melhor coisa, mas desde que isso fosse realmente ensinado e conduzido desde o } \\
\text { começo do pré-natal, porque o que falta no nosso povo é a educação básica. } \\
\text { Sujeitos: (O3, O5) }\end{array}$ & $\begin{array}{l}\text { Desumano é quando as mulheres chegam para nós, e que não } \\
\text { fez um pré-natal adequado. Durante o pré-natal ela teve muita } \\
\text { dificuldade, quase não fez, fez uma, duas consultas. Por não } \\
\text { fazerem, elas não sabem o que está acontecendo, é problemático } \\
\text { no momento do pré-parto, no momento do parto. É muito dificil, } \\
\text { é mais complicado ainda, dá trabalho, eu acho que o pré-natal é } \\
\text { fundamental, para humanização. Então falta isso. O pré-natal, } \\
\text { que em determinados lugares não propiciam para ela. Fica meio } \\
\text { complicado, ai chega para nós, já é um problema, porque a gente } \\
\text { tenta amenizar da melhor maneira possivel. Então começa, eu } \\
\text { acho que a humanização, desde o pré-natal se ela não tem um } \\
\text { pré-natal legal, provavelmente, já começa não ter uma } \\
\text { humanização adequada. (E8) }\end{array}$ \\
\hline
\end{tabular}




\section{DISCURSO DO SUJEITO COLETIVO}

\section{Cite itens de desumanização neste hospital.}

\begin{tabular}{|c|c|c|c|c|c|}
\hline $\begin{array}{c}\text { IDÉLA } \\
\text { CENTRALJ }\end{array}$ & \multicolumn{2}{|l|}{ Profissionais da Área Administrativa } & \multicolumn{2}{|c|}{$\begin{array}{l}\text { Outros Profissionais } \\
\text { da Área Assistencial }\end{array}$} & $\begin{array}{l}\text { Lideres Setoriais } \\
\text { de Acolhimento }\end{array}$ \\
\hline $\begin{array}{c}\text { Obstáculos a } \\
\text { implantação da } \\
\text { inter- } \\
\text { disciplinaridade } \\
\text { no acolhimento ao } \\
\text { usuário }\end{array}$ & \multicolumn{2}{|c|}{$\begin{array}{l}\text { É justamente isso, da profissão, da especialização, se o médico é especializado em retirar a dor, vamos } \\
\text { dizer, então só ele pode fazer isso e, se o pessoal da limpeza é recolher o lixo, só ele pode fazer isso. } \\
\text { Quando é colocado a humanização, a pessoa que viu primeiro, na hora, não pode esperar um minuto para } \\
\text { socorrer. Então, quem viu primeiro tem que socorrer, existe um atrito, quando alguém vai socorrer, porque a } \\
\text { outra pessoa que deveria, que é dado essa profissão, que não socorreu, se senti invadida. Existe mesmo, } \\
\text { acontece muito, nós do arquivo muitas vezes estamos na recepção, as vezes uma paciente está com dor, ela } \\
\text { pede para chamar o médico, que para paciente, ela não sabe, o que cada um tem que fazer, ela não sabe que } \\
\text { é a enfermeira, que tem que fazer aquilo. Então, ela pede paro o primeiro que aparece, ela esta com dor, aí a } \\
\text { gente vai e faz, a enfermeira se sente ofendida, várias vezes a gente levou bronca dela: "Invadindo nosso } \\
\text { setor, isso não é função de vocês". } \\
\text { Sujeitos: (OAI) }\end{array}$} & & & \\
\hline \multicolumn{6}{|c|}{ O discurso desta categoria foi construído com o depoimento de um oficial administrativo. } \\
\hline \multicolumn{6}{|c|}{ Cite itens de desumanização neste hospital. } \\
\hline $\begin{array}{c}\text { IDÉ IA } \\
\text { CENTR } 1 L K\end{array}$ & $\begin{array}{l}\text { Médicos (Obstetras, Residentes, Neonatologistas, } \\
\text { Anestesiologistas, UTI Materno e Neonatal) }\end{array}$ & \multicolumn{2}{|c|}{$\begin{array}{c}\text { Profissionais da Área } \\
\text { Administrativa }\end{array}$} & \multicolumn{2}{|c|}{$\begin{array}{l}\text { Líderes Setoriais de } \\
\text { Acolhimento }\end{array}$} \\
\hline $\begin{array}{c}\text { As ações de } \\
\text { humanização } \\
\text { estão evoluindo } \\
\text { lentamente na } \\
\text { instituição }\end{array}$ & $\begin{array}{l}\text { Os profissionais já tiveram treinamento, mas não se dispõem a quebrar os seus } \\
\text { paradigmas. Existe analgesia de parto disponivel no Hospital há muito tempo, é só } \\
\text { os obstetras pedirem, mas há pouca solicitação. } \\
\text { Sujeitos: (N4) }\end{array}$ & \multicolumn{2}{|c|}{$\begin{array}{l}\text { Um ponto de desumanização do parto, é } \\
\text { que as açðes de humanização estão indo } \\
\text { muito devagar. Não está indo com } \\
\text { rapidez do jeito que era planejado. } \\
\text { Sujeitos: (OA4) }\end{array}$} & & \\
\hline
\end{tabular}




\section{DISCURSO DO SUJEITO COLETIVO}

\section{Cite itens de desumanização neste hospital}

\begin{tabular}{|c|c|c|}
\hline $\begin{array}{c}\text { IDEIA } \\
\text { CENTRALL } \\
\end{array}$ & $\begin{array}{l}\text { Profissionais da área } \\
\text { Administrativa }\end{array}$ & Lideres Setoriais de Acolhimento \\
\hline $\begin{array}{l}\text { Ausência de uma lígica } \\
\text { contratual por parte da } \\
\text { Secretaria de Estado da } \\
\text { Saúde }\end{array}$ & $\begin{array}{l}\text { "Ganhar todas iguais, porque nåo esta sendo } \\
\text { assim e somos todos do mesmo setor". } \\
\text { Sujeitos: (ZI) }\end{array}$ & $\begin{array}{l}\text { Não têm refeiçðes para os funcionários terceirizados .eles năo são do Estado e não têm direito a } \\
\text { alimentaçăo. Os funcionários contratados são mais precionados que os efetivos. Se a gente fala que } \\
\text { não pode fazer extra dizem que não vão renovar nosso contrato. Trabalhamos sob pressão }\end{array}$ \\
\hline
\end{tabular}

\begin{tabular}{|c|c|c|c|}
\hline $\begin{array}{c}\text { IDEIA } \\
\text { CENTRALM }\end{array}$ & Profissionais da Área Administrativa & $\begin{array}{c}\text { Outros Profissionais da Área } \\
\text { Assistencial }\end{array}$ & $\begin{array}{c}\text { Lideres Setoriais de } \\
\text { Acolhimento }\end{array}$ \\
\hline $\begin{array}{l}\text { Carência de treinamentos } \\
\text { para todos os } \\
\text { profissionais (desde o } \\
\text { segurança ate os médicos) }\end{array}$ & $\begin{array}{l}\text { Cursos, treinamentos, muitos treinamentos, eu acredito que treinamento } \\
\text { iria resolver todos esses problemas, e quem não tivesse de acordo tentar } \\
\text { colocar em outro setor, e colocar pessoas de perfil para receber a } \\
\text { mãezinha. Treinamento está faltando aqui, tanto para, desde a } \\
\text { recepcionista, desde o guarda até o médico. } \\
\text { Sujeitos: (OA3) }\end{array}$ & & \\
\hline
\end{tabular}




\section{DISCURSO DO SUJEITO COLETIVO}

\section{A estrutura fisica deste hospital atrapalha o processo de humanização da assistência?}

\begin{tabular}{|c|c|c|}
\hline $\begin{array}{c}\text { IDELIA } \\
\text { CENTRALC }\end{array}$ & $\begin{array}{l}\text { Médicos (Obstetras, Residentes, Neonatologistas, Anestesiologistas, } \\
\text { UTI Materno e Neonatal) }\end{array}$ & Direção do HMI e Ambulatório \\
\hline $\begin{array}{l}\text { A estrutura } \\
\text { física } \\
\text { atrapalha o } \\
\text { processo de } \\
\text { Humanização } \\
\text { da Assistência }\end{array}$ & $\begin{array}{l}\text { Nosso hospital é um hospital pequeno, ele tem um porte pequeno. Necessitariam de mais } \\
\text { espaço fisico para ele. Atrapalha, obviamente atrapalha, a estrutura fisica ela é, você } \\
\text { precisa ter espaço, para você poder fazer a humanização, das formas que estão sendo } \\
\text { elaboradas. Você tem que ter espaço para poder o marido vir, é, para ter, que andar, tem } \\
\text { que ficar, ele tem que comer a vontade, ele fica a vontade o paciente, na realidade e tem } \\
\text { que ter um profissional a disposição, desde a enfermeira obstétrica, um médico na } \\
\text { urgência, no atendimento de urgência, está todo mundo voltado aquela paciente, } \\
\text { preparados voltados para aquela paciente. O espaço físico não permite a paciente andar, } \\
\text { não proporciona maior liberdade para paciente. Se você tivesse um espaço maior para ter } \\
\text { os pré-partos adequados para humanização e o pai ou a mãe da gestante, o ente querido } \\
\text { que ela queria que estivesse ali naquele momento com ela, teria que nascer dali, do pré- } \\
\text { parto ao centro cirúrgico, essas pessoas sempre acompanhando ela e com um espaço fisico } \\
\text { limitado a gente não tem como recebê-los. O que limita, ele ficará melhor, é o espaço } \\
\text { fisico, em todos os projetos que a gente tinha para, tanto que nós estamos implantando } \\
\text { agora a humanização do parto, analgesia de parto, tudo que favoreça a mulher, porque em } \\
\text { pleno século XXI a pessoa sentir dor na hora do parto é ridiculo. Atrapalha, nesse ponto } \\
\text { atrapalha. As vezes tem seis, as vezes tem dez pacientes lá dentro, fica inviável você por } \\
\text { um acompanhante. Mesmo se por exemplo, é uma adolescente que você deveria por um } \\
\text { acompanhante junto, fica meio dificil. Já houve casos, por exemplo, da gente ter um pré- } \\
\text { parto cheio, onde as pacientes chegam ficar até, sentadas em cadeiras lá do pré-parto } \\
\text { porque nåo tem mais leitos para elas. Então, quer dizer, se fosse, um pré-parto maior, uma } \\
\text { sala de parto maior, todas as pacientes estariam alojadas, nos seus leitos. Que é muito } \\
\text { mais confortável. Eu acho que atrapalha muito, porque não tem como colocar } \\
\text { acompanhante, não dá para ter uma assistência boa em parte humanização sem ter um } \\
\text { espaço maior. Eu acho que não dá. } \\
\text { Sujeitos: (OI, O2, O3, Al, RD, RB, RA) }\end{array}$ & $\begin{array}{l}\text { Com certeza. Se você nåo tem espaço para acolher os familiares, o } \\
\text { marido na sala de parto, se você não tem espaço para fazer uma sala de } \\
\text { acolhimento adequada, se você não tem área fisica para poder acomodar } \\
\text { as pacientes no pós-parto e as condiçoes que você tem de assistência, } \\
\text { você vai limitar bastante esse tipo de atendimento. A filosofia existe, a } \\
\text { intenção existe, mas se você não tem espaço para acomodar é } \\
\text { impossivel ser plenamente aquilo que você está querendo. No momento } \\
\text { não tem como entrar o acompanhante masculino por causa que o pré- } \\
\text { parto é coletivo, mas nós já temos um projeto de fazer uma construção } \\
\text { de uma área anexa e inauguração de sete leitos de ... aqui no hospital. } \\
\text { Hoje em dia é inviável termos o acompanhante feminino do pré-parto, } \\
\text { pelo fluxo de trabalho, pela área fisica estreita, por excesso de pessoas } \\
\text { Não esqueça que estar o acompanhante do lado é um fator que você tem } \\
\text { como ajuda, mas também é um fator que vai contaminar e vai prejudicar } \\
\text { a assistência porque você aumenta o risco de contaminação, a falta de } \\
\text { espaço para movimentação e cria tumulto no ambiente que você não } \\
\text { tem necessidade. Hoje já temos ultimamente um trabalho realmente } \\
\text { muito tumultuado lá em cima. Inclusive as vezes com acesso de } \\
\text { paciente na área, além do próprio médico assistente, do residente, da } \\
\text { enfermagem, certamente é um excesso de pessoal dentro de uma área } \\
\text { muito restrita e pequena e isso faz com que impeça que entre o } \\
\text { acompanhante independente do sexo masculino ou feminino. Isso influi } \\
\text { demais no ambiente. Se comparar as dimensões no pré-parto que cabe } \\
\text { seis leitos, realmente eu acho que nós estamos trabalhando em } \\
\text { condiçð̃es muito errônea, mas infelizmente a gente não tem muita opção } \\
\text { Sujeitos: (DC) }\end{array}$ \\
\hline
\end{tabular}




\section{DISC CIRSO DO SUJEITO COLETIVO}

\section{A estrutura física deste hospital atrapalha o processo de humanização da assistência?}

\begin{tabular}{|c|c|c|c|}
\hline $\begin{array}{c}\text { IDÉlA } \\
\text { CENTRALC }\end{array}$ & Profissionais da área Administrativa & Outros profissionais da área Assistencial & $\begin{array}{l}\text { Líderes Setoriais } \\
\text { de Acolhimento }\end{array}$ \\
\hline $\begin{array}{l}\text { A estrutura } \\
\text { física } \\
\text { atrapalha o } \\
\text { processo de } \\
\text { Humanização } \\
\text { da Assistência }\end{array}$ & $\begin{array}{l}\text { Muito, eu acho que atrapalha sim, as vezes aqui é um local que } \\
\text { muitas mãezinhas vem procurar o Hospital Maternidade Interlagos, e } \\
\text { várias vezes elas não podem ser internadas aqui e têm que ser } \\
\text { transferidas para um local muito longe, e isso eu acho que se o } \\
\text { hospital fosse maior para atender toda demanda seria bom. } \\
\text { Atrapalha, atrapalha muito. Porque o hospital foi construido para ser } \\
\text { um hospital geral, aos poucos que ele foi se tornando maternidade. } \\
\text { Então, ele não tem uma infra-estrutura para, humanização do parto. } \\
\text { Tanto esse, como muitos hospitais que eu conheço, que são prédios } \\
\text { antigos, que só tem estrutura para coisas que eram antigas e nem se } \\
\text { pensava nisso antes. Sem dúvida! Atrapalha mesmo. Vamos } \\
\text { considerar o alojamento conjunto, eu Acho o alojamento conjunto } \\
\text { uma coisa muito boa. É bom, mas eu acho um pouquinho apertado. } \\
\text { Tanto que tem mães adolescentes que vêem visitar o hospital, } \\
\text { permanecer no hospital e não tem condições. É lei? É lei. Ela pode? } \\
\text { Pode, deve até, mas não tem condiçąes dela ficar mesmo a vontade. } \\
\text { Nem tem ambiente de colocar uma cadeira do lado. Esse hospital está } \\
\text { pequeno. Na situação de ter tanta, gente procurando ele, eu acho ele } \\
\text { pequeno. O berçário também, eu acho um pouquinho pequenininho, } \\
\text { mas também não vai tanta criança para o berçário. Mas é isso, o resto } \\
\text { eu não vejo, nem aqui em baixo mesmo, eu acho que está bem } \\
\text { distribuido, é só mesmo no alojamento conjunto tem hora que a gente } \\
\text { passa um sufoco lá em cima e não dá para fazer aquele sucesso, coisa } \\
\text { de humanização mesmo, acaba ficando bem apertadinho mesmo. } \\
\text { Mas, fora isso, nada. } \\
\text { Sujeitos: (OA3. OA4, OA5) }\end{array}$ & $\begin{array}{l}\text { Atrapalha, bastante. O hospital tem muita demanda de paciente, } \\
\text { sempre está lotado, não dá para você dar aquela atenção especial, } \\
\text { porque tem muita gente. Tem muita demanda de paciente, para pouco } \\
\text { leito, tanto no alojamento conjunto, como no pré-parto. A estrutura } \\
\text { fisica é pequena. Pela demanda, ele é um hospital pequeno, poderia } \\
\text { aumentar um pouco mais. O espaço fisico aqui é muito, muito } \\
\text { precário, a área fisica é precária. Aqui no PS nós dispomos de dois } \\
\text { leitos aqui, antes eram quatro, mas agora melhorou um pouco, mas } \\
\text { ainda não é o ideal. Eu realmente, nisso eu sou sincera o espaço fisico } \\
\text { aqui é uma coisa assim que é muito dificil tanto para o funcionário } \\
\text { como para paciente é complicado, complicado mesmo. Mas, eu sei } \\
\text { que é uma coisa que não depende da, é uma coisa que teria que ir para } \\
\text { um outro lugar, teria que sabe, ou então começar a alugar todas as } \\
\text { casa aqui em volta. Então, é uma coisa assim que, chegou uma hora } \\
\text { que é uma situação que a gente enfrenta, todos nós enfrentamos, mas } \\
\text { a gente tem que está entendendo que é uma coisa que é assim até ser } \\
\text { solucionado, não depende do Diretor, da Dra. Não depende assim, a } \\
\text { gente precisaria ir para um outro lugar ou ocupar todas as residências } \\
\text { aqui, a parte administrativa saísse fora daqui, aqui ficasse só o } \\
\text { Hospital, mas acho que nem assim suportaria a demanda. Á́ sim, isso } \\
\text { é verdade, aliás é um ponto crítico aqui da Maternidade é o nosso } \\
\text { espaço. Tudo é pequeno, tem o pré-parto, o banheiro, as nossas } \\
\text { salinhas aqui, onde você vai é pequeno, tudo é pequeno. O espaço } \\
\text { fisico aqui realmente deixa a desejar e isso acaba acarretando alguns } \\
\text { contratempos. } \\
\text { Sujeitos: (E7, AEl, AE3) }\end{array}$ & \\
\hline
\end{tabular}




\section{DISCURSO DO SUJEITO COLETIVO}

\section{A estrutura física deste hospital atrapalha o processo de humanização da assistência?}

\begin{tabular}{|c|c|c|}
\hline $\begin{array}{c}\text { IDEIA } \\
\text { CENTRALD }\end{array}$ & $\begin{array}{l}\text { Médicos (Obstetras, Residentes, Neonatologistas, } \\
\text { Anestesiologistas, UTI Materno e Neonatal) }\end{array}$ & Direção do HMI e Ambulatório \\
\hline $\begin{array}{l}\text { A estrutura } \\
\text { física } \\
\text { atrapalha } \\
\text { muito pouco o } \\
\text { processo de } \\
\text { Humanização } \\
\text { da Assistência }\end{array}$ & $\begin{array}{l}\text { Um pouquinho. A demanda do hospital é alta, essa região é } \\
\text { muito carente, acho que precisaria de um hospital um pouco } \\
\text { maior, acho que precisava distribuir um pouco melhor as mães, } \\
\text { porque em épocas do ano, nós temos uma super lotação. A gente } \\
\text { precisava, talvez um pouco maior. Enfermarias um pouco } \\
\text { maiores, bem arejadas para as mães poderem se acomodar } \\
\text { melhor e passar suas } 48 \text { horas mais bem acomodadas. É dificil de } \\
\text { responder isso. Eu acho que todo o hospital que é por andares, } \\
\text { tipo você tem uma distância entre pronto socorro e atendimento, } \\
\text { pronto socorro e berçário, você tem uma dificuldade maior, mas } \\
\text { eu não acho que em termo de humanização isso seja algum } \\
\text { impedimento, tanto que a gente tem a enfermaria do hospital e o } \\
\text { banco de leite é no terceiro andar, e em menos de trinta } \\
\text { segundos, ou o berçarista ou a enfermeira do banco de leite ta no } \\
\text { Alojamento Conjunto, esta junto da mãe. Então, eu não acho que } \\
\text { atrapalha não, eu não vejo pontos negativos quanto a isso. } \\
\text { Sujeitos: (N1, N2) }\end{array}$ & $\begin{array}{l}\text { E, a estrutura fisica em algumas situações ela atrapalha um pouco. Uma estrutura muito acanhada, } \\
\text { uma estrutura muito pequena para um processo médico, pode as vezes comprometer a saúde da } \\
\text { gestante, da parturiente. Em alguns setores a gente procura ampliar, para que possa dar o suporte } \\
\text { necessário para que aquelas pessoas que vão ali circular não prejudique o atendimento. O principal } \\
\text { é o procedimento, agora também, a gente tem que ajudar para que este procedimento tenha } \\
\text { sucesso,para que a parte emocional da paciente tenha suporte também. Se a gente poder juntar as } \\
\text { duas coisas, é o ideal. A estrutura fisica não impede o processo de humanização. Uma má estrutura } \\
\text { fisica, ela atrapalha que você implante um projeto a contento. Mas a estrutura fisica por mais } \\
\text { acanhada que ela seja, ela não impede que você implante um processo de humanização. Seria mais } \\
\text { eficiente se tivesse um espaço amplo, para implantar salas de PPP. Mais espaço nos facilitaria no } \\
\text { trabalho de acolhimento do binômio mãe x bebê. A nossa estrutura fisica, ela é muito pequena. } \\
\text { Mas a gente consegue se manter aqui dentro. Quanto a humanização, não sei se isso afeta tanto, } \\
\text { porque, a estrutura fisica ela atrapalha um pouco por ser pequena, mas dá para se movimentar. } \\
\text { Porque se a gente consegue trabalhar num local, que a estrutura fisica é pequena, mas a gente } \\
\text { continua fazendo um ótimo trabalho, como todo mundo tem conhecimento, então a estrutura não } \\
\text { vai bloquear nada, eu acho que o atendimento, a pessoa, o funcionário tem que se conscientizar } \\
\text { disso. Sujeitos: (DG, DU, DRH) }\end{array}$ \\
\hline
\end{tabular}




\section{DISCURSO DO SU.JEITO COI.FIVIO}

\section{Qual o profissional que mais colabora com o processo de humanização da assistência?}

\begin{tabular}{|c|c|c|}
\hline $\begin{array}{c}\text { IDEIA } \\
\text { CENTRALE }\end{array}$ & $\begin{array}{l}\text { Médicos (Obstetras, Residentes, } \\
\text { Neonatologistas, Anestesiologistas, } \\
\text { UTI Materno e Neonatal) }\end{array}$ & Outros Profissionais da Área Assistencial \\
\hline $\begin{array}{l}\text { Todos } \\
\text { colaboram no } \\
\text { processo de } \\
\text { Iumanização } \\
\text { da Assistência }\end{array}$ & $\begin{array}{l}\text { Acho que todo mundo colabora, não tem } \\
\text { essa de qual mais colabora, todo mundo } \\
\text { tem que colaborar, desde que esteja no } \\
\text { programa de humanização ao parto e uma } \\
\text { forma geral aqui no hospital, eu acho que } \\
\text { tanto a equipe médica, GO, anestesista, } \\
\text { pediatra, a equipe de enfermagem. Por nós } \\
\text { sermos um hospital pequeno, acho que } \\
\text { todo mundo se conhece, como todo mundo } \\
\text { se vê toda semana, o clima já é diferente, o } \\
\text { tratamento já é mais familiar. } \\
\text { Sujeitos: (O2, N2) }\end{array}$ & 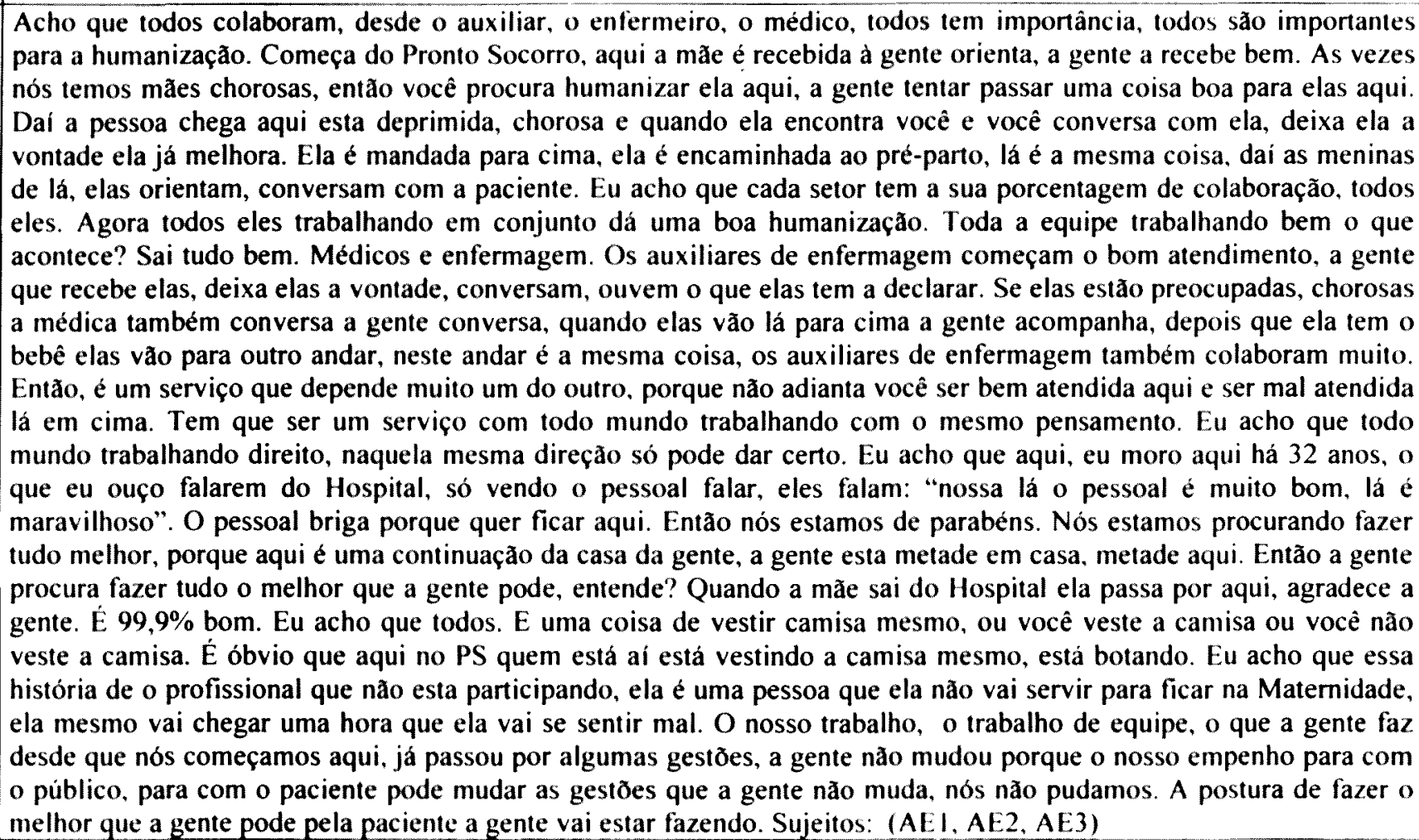 \\
\hline
\end{tabular}




\section{DISCURSO DO SUJEITO COLETIVO}

Qual o profissional que mais colabora com o processo de humanização da assistência?

\begin{tabular}{|c|c|c|}
\hline $\begin{array}{c}\text { IDEEIA } \\
\text { CENTR.ALF }\end{array}$ & \begin{tabular}{|c|} 
Médicos (Obstetras, Residentes, \\
Neonatologistas, Anestesiologistas, UTI \\
Materno e Neonatal)
\end{tabular} & Direção do HMI e Ambulatório \\
\hline $\begin{array}{c}\text { O processo de } \\
\text { humanização da } \\
\text { assistência } \\
\text { independe da } \\
\text { especialidade } \\
\text { e/ou profissão do } \\
\text { profissional, mas } \\
\text { sim o seu } \\
\text { comportamento }\end{array}$ & $\begin{array}{l}\text { Depende de cada um. Depende do compromisso } \\
\text { de cada um eu acho com a profissão. Bem isso } \\
\text { mesmo, do compromisso, o comprometimento } \\
\text { mesmo. } \\
\text { Sujeitos: (RB, RC) }\end{array}$ & $\begin{array}{l}\text { Em termos institucionais novamente volta aquele ponto, não dá para nominar categoria, neste momento, } \\
\text { nesta primeira avaliação você considera isso, pode ser que em um segundo momento, em uma outra } \\
\text { avaliação daqui a algum tempo você mude de opinião. Não dá para nominar e eu não considero como } \\
\text { categorias que colaboram mais ou sejam mais contrárias ao processo. O profissional que tem claro os } \\
\text { objetivos da instituição, seus valores, suas metas e está sensibilizado para a importância de estabelecer uma } \\
\text { parceria nas aç̃̃es que realiza com o usuário que está atendendo. O profissional que sabe ouvir, } \\
\text { compreender e acredita na capacidade de ação, escolha e participação do outro. O profissional tecnicamente } \\
\text { capaz, disposto a apreender e a mudar. Atividades motivacionais são aquelas que mais podem colaborar no } \\
\text { processo de humanização. Numa estrutura como a da saúde, onde não existe plano de carreira e nem } \\
\text { recompensas pecuniárias pelo desempenho, somente a motivação faz com que projetos sejam implantados } \\
\text { com sucesso. O que ajuda muito são treinamentos para os funcionários, para eles saberem o que é o parto } \\
\text { humanizado. Então, muitas pessoas não sabem ainda o que é o parto humanizado. Então eu acho que o } \\
\text { treinamento para as pessoas saberem a divulgação de que isso ocorre. É mais importante. } \\
\text { Sujeitos: (DC, DA, DU, DRH) }\end{array}$ \\
\hline
\end{tabular}
e um Diretor de Recursos Humanos. 


\section{DISCURSO DO SUEITO COLETIVO}

Qual o profissional que mais colabora com o processo de humanização da assistência?

\begin{tabular}{|c|c|c|}
\hline $\begin{array}{l}\text { IDELA } \\
\text { CENTRALG }\end{array}$ & $\begin{array}{c}\text { Médicos (Obstetras, Residentes, Neonatologistas, Anestesiologistas, UTI Materno } \\
\text { e Neonatal) }\end{array}$ & $\begin{array}{c}\text { Direção do HMI e } \\
\text { Ambulatório }\end{array}$ \\
\hline $\begin{array}{l}\text { Oprocesso de humanizaçāo da } \\
\text { assistência independe da } \\
\text { especialidade c/ou profissāo do } \\
\text { profissional, mas sim de um pré- } \\
\text { natal con qualidade }\end{array}$ & $\begin{array}{l}\text { Uma assistência ao pré-natal, desde o inicio, desde a primeira consulta do pré-natal, as gestantes serem } \\
\text { preparadas para isso, ter reuniðes com elas explicando tudo o que acontece, mostrando o material que } \\
\text { vai ser usado, tirando o estigma da anestesia, o estigma que muitas delas acham que essa anestesia para } \\
\text { tirar a dor vai inibir o trabalho de parto dela, ela se sente insegura, ela acha que aquilo vai prejudicar o } \\
\text { nenê dela e nada disso acontece, tudo isso é para o conforto dela, para ela ter um parto humanizado, } \\
\text { normal. } \\
\text { Sujeitos: (Al) }\end{array}$ & \\
\hline
\end{tabular}




\section{DISCIRSO DO SUJEITO (OI.ETIVO}

\section{Qual o profissional que tem maior resistência ao processo de humanização da assistência?}

\begin{tabular}{|c|c|c|c|}
\hline $\begin{array}{c}I D E I A \\
C E N T R A L E\end{array}$ & $\begin{array}{l}\text { Profissionais da área } \\
\text { Administrativa }\end{array}$ & Outros profissionais da área Assistencial & $\begin{array}{c}\text { Lideres Setoriais } \\
\text { de Acolhimento }\end{array}$ \\
\hline $\begin{array}{l}\text { O processo de } \\
\text { humanização da } \\
\text { assistência } \\
\text { independe da } \\
\text { especialidade } \\
\text { e/ou profissão do } \\
\text { profissional, mas } \\
\text { sim o seu } \\
\text { comportamento }\end{array}$ & & $\begin{array}{l}\text { Eu não acho que tenha profissional que atrapalhe mais, e nem profissional que atrapalhe menos. Eu } \\
\text { acho que é sempre a questão da conduta mesmo e da atitude. Eu acho que a partir do momento que o } \\
\text { profissional, as vezes até o profissional que num determinado momento. Tomou uma atitude que, } \\
\text { pareceu uma atitude, que a gente, aí esse daí foi desumanizado, nossa que horror! De repente se os } \\
\text { outros que estão em volta, conseguem se antenar com isso, e usar isso como uma coisa de crescimento, } \\
\text { vira um degrau. Que até faz você discutir o assunto. Você viu o que fulano fez? Então, a gente para pra } \\
\text { pensar sobre aquilo. Não dá para você dizer, que um é melhor, que um é pior, que um ajudou mais, que } \\
\text { um atrapalhou mais, eu acho que é uma questão de conjunto e de equipe. Eu acho que é por aí. Olha, eu } \\
\text { não vejo assim qual o profissional que atrapalha mais, vai muito de pessoa para pessoa. Pode ser } \\
\text { médico, enfermeiro, o que for, auxiliar, que as vezes trata bem os pacientes, outros não, isso eu acho, } \\
\text { que vai muito da pessoa. Acho que não tem um profissional que atrapalha, não vou falar, o médico, o } \\
\text { enfermeiro, o auxiliar, não. Acho que todos são da mesma equipe, então todo mundo tem a sua } \\
\text { participação. Não sei quem não atrapalha, muitas vezes você vê o médico atrapalhou. Pode ser até a } \\
\text { pessoa dela, nem todo mundo é igual. Tem um que trata melhor, outro que é mais carrasco, outro que } \\
\text { não liga. Não acho que tem um profissional que atrapalha, acho que todos trabalham bem. Nenhum } \\
\text { profissional. Acho que é a pessoa que não tem vontade, que ela não tem aquele espírito esportivo, } \\
\text { aquele espirito de querer ajudar, de ficar em harmonia com o pessoal. } \\
\text { Sujeitos: (PI, E7, Fl) }\end{array}$ & \\
\hline
\end{tabular}




\section{DISCURSO DO SUJEITO COLETIVO}

\section{Você acha que o Pré-Natal influencia o processo de humanização da assistência?}

\begin{tabular}{|c|c|c|}
\hline $\begin{array}{c}I D E I A \\
C E N T R / / B\end{array}$ & Profissionais da Área Administrativa & Outros Profissionais da Área Assistencial \\
\hline $\begin{array}{l}\text { O Pré-Natal } \\
\text { é a base da } \\
\text { humanização } \\
\text { devido as } \\
\text { ações } \\
\text { educativas }\end{array}$ & $\begin{array}{l}\text { Influencia sim, porque eu acho que você fazendo o pré- } \\
\text { natal, você já fica mais por dentro da situação, Já sabe o } \\
\text { que vai acontecer mais para frente. Com certeza. A mãe } \\
\text { fica ciente de tudo que pode estar ocorrendo. Ela já vai } \\
\text { ciente do hospital, onde é, ela sai do pré-natal } \\
\text { praticamente dentro de todos os conhecimentos. Todos } \\
\text { os conhecimentos para o bem do seu filho ela já vai sair. } \\
\text { Influencia sim, as pessoas chegam aqui desorientadas, } \\
\text { não sabem qual balcão que ela procura, chegam com um } \\
\text { papel que às vezes com um endereço que não é daqui, } \\
\text { outro diferente, então agente procura ajudar auxiliar } \\
\text { essa pessoa para ir ao local certo, então acho que } \\
\text { influencia muito, essa humanização que você falou. Eu } \\
\text { acho que influência bastante, porque é a primeira } \\
\text { impressão é a que fica, se a mãe ela é tratada bem, desde } \\
\text { o começinho bem, pelos médicos, enfermeiras, } \\
\text { auxiliares, desde o começinho do pré-natal, eu creio que } \\
\text { ela tem uma gestação bastante evolutiva, produtiva, uma } \\
\text { gestação ótima. Os resultados são ótimos. São } \\
\text { resultados diferentes. Influencia, influencia muito. } \\
\text { Porque pelo o que eu mexo nas estatísticas, a paciente } \\
\text { que não, não se interessa muito pelo pré-natal, ela tem } \\
\text { muita dificuldade, ela tem muito medo. Eu já vi muitas } \\
\text { pacientes perderem a criança porque, não fez o pré-natal } \\
\text { ou porque nem sabe o que é o pré-natal. A gente recebe } \\
\text { pessoas de Parelheiro, tribos Indigenas que não sabem } \\
\text { nem o que é isso, só vem aqui para ter a criança, logo no } \\
\text { nono mês, não sabe, não teve nenhum acompanhamento } \\
\text { médico durante os nove meses. }\end{array}$ & 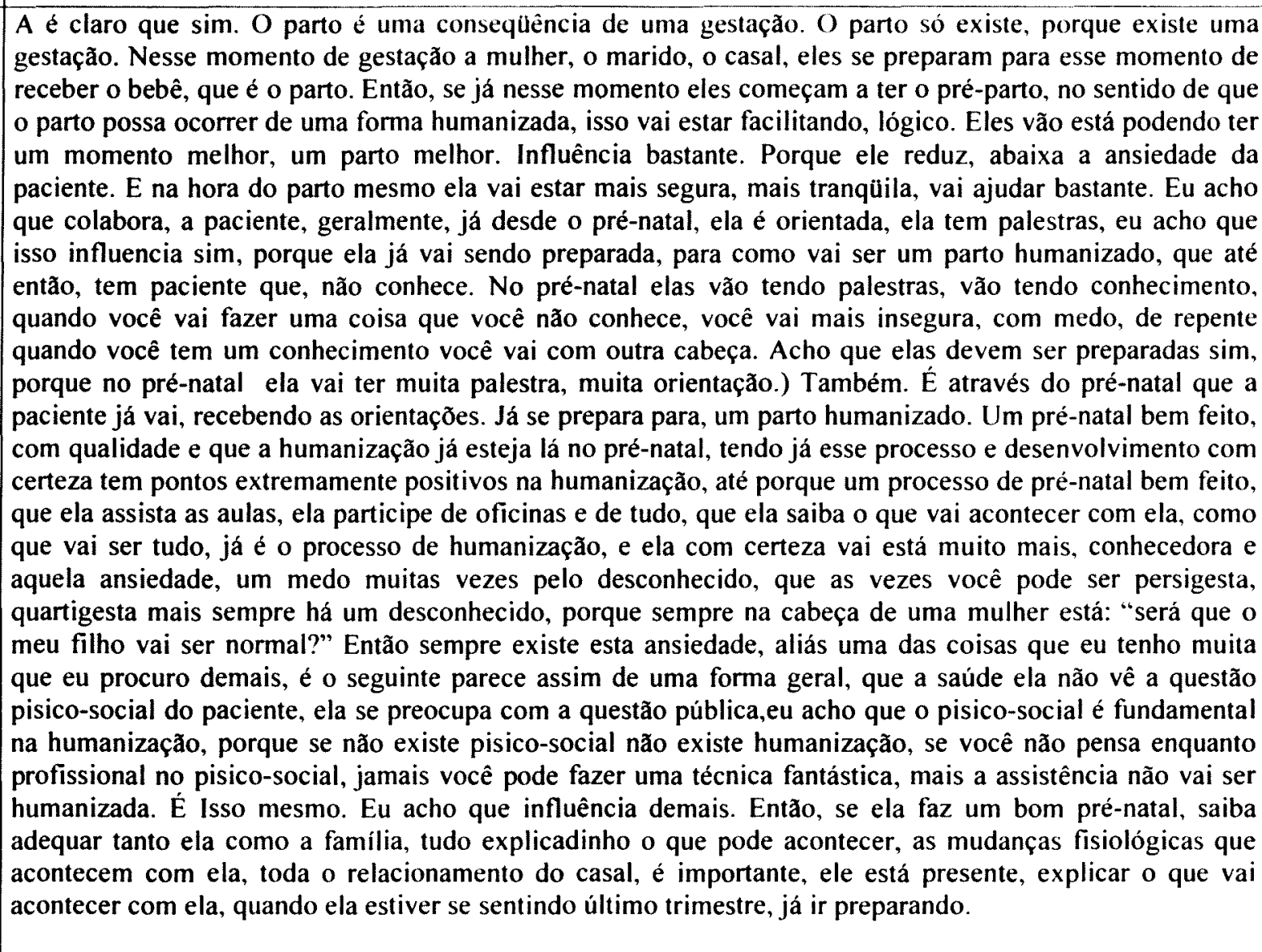 \\
\hline
\end{tabular}


Porque aí elas vão estar mais preparadas. Com o prénatal elas vêem mais preparadas $\mathrm{e}$ isso facilita ainda para gente estar reforçando as informações. $O$ médico que faz o pré-natal elas confiam muito. Então, chega aqui, as informaçðes batem com o que ela aprendeu no pré-natal e com quem ela está sendo avaliada na hora e isso é muito bom. Então, ela se sente mais confiante, ela confia no médico que fez o pré-natal e no médico daqui. Isso é bom, ela vir com informaçðes, ter noçðes do que acontece. As que não fazem, o trabalho da gente é muito mais, tem que empenhar muito mais. Com certeza. Porque a palestra de pré-natal, já é importante aqui, porque as mães já saem daqui se prevenindo para não ter uma gravidez indesejada, já saem sabendo como vai ser o parto. Então isso ajuda bastante. Influência, eu acho legal isso. Porque as pessoas ficam mais informatizadas. A maioria das pessoas, tem muitas adolescentes grávidas e logo depois eles marcam uma consulta, um planejamento familiar então ajuda bastante. Geralmente a maioria tem um filho só, porque veio nas consultas. $\dot{E}$ a formação do bebê. E se não houver esse atendimento ao pré-natal, as vezes pode acontecer algo depois do parto que depois não pode ter mais jeito. Totalmente. As pessoas se sentindo bem desde o começo, até a hora do parto com certeza ela vai se sentir com bastante segurança, se ela tiver um prénatal que já dê toda base para ela, acho que o pré-natal é a base. Com certeza, é do pré-natal que vem a segurança da mãe, então se ela for bem recepcionada no pré-natal, ter um tratamento adequado do médico, com certeza ela vem com uma segurança maior e o parto dela será maravilhoso.

Sujeitos: (S1, S2, S3, S4, OA4, OA5, AL3, AL1, OA1, $\mathrm{OA} 2, \mathrm{OA} 3$ )

Então, quando ela chega por aqui, ela já é uma pessoa totalmente preparada, capacitada, ela sabe o que está acontecendo, ela é colaborativa. A gente orientar no terceiro trimestre, de como ela respirar, para ajudar. Agora se ela não faz um bom pré-natal, a família não apóia. Enfim, tudo isso, aí fica bem complicado. Se torna até um pouco desumanizado, porque até, elas vão dizer: "Mas isso dói muito", "Mas, eu não sabia que era assim", "Tira essa criança de dentro de mim". O que ela grita no auge da dor. Porque aqui ela não teve preparo nenhum, nenhum. Emocional. As mudanças, só sabe o que a vizinha disse, o que o fulano disse. Então, fica meio complicado. Lógico. Influência muito também na orientação da paciente. Eu acho que a paciente bem orientada no pré-natal, ela tem uma conduta melhor no trabalho de parto, porque às vezes o desespero da paciente no trabalho de parto leva a uma conduta desnecessária. Influência o profissional Muito. Influência sim. Eu acho que influência em todo caso, tem vários seguimentos, porque nó pré-natal eu sempre acreditei muito no pré-natal, eu acho que no pré-natal é que a mãe esta mais sensível e ela absorve melhor todas as experiências. Quando a mãe ela está mais sensível, quando ela esta assim, ela acredita mais. Quando fica mais fácil para gente prepará-la para humanização. Quando ela começa ser preparada no pré-natal, ela fica mais sem medo, ela não vem tão armada para cá. Então, isso facilita para nós. Sim, sem nenhuma dúvida. O processo de gestação se inicia com a notícia do exame positivo e nas consultas de pré-natal, em que os profissionais podem mostrar interesse pela paciente e darão continuidade a esse processo de humanização. Eu acho muito importante, porque a mãe engravidou ela vai fazer o prénatal. Ali ela já vai começar a ser orientada, ela já vai se preparando para Maternidade. Ela sendo preparada lá quando ela chega aqui, ela não chega tão tensa, quando ela chega aqui a gente conversa com ela e ela está semi-preparada, por causa do pré-natal. Chega aqui você fala que ela vai fazer isso, isso e isso, diz quando ela vai ser atendida aqui, quando ela vai ir lá para cima. Então, ela já está bem tranquiila. As vezes acontece da mãe vir nervosa, mas é muito raro. Geralmente ela esta mais calma porque ela fez o pré-natal. Eu acho que o pré-natal é o início, a partir de lá preparam ela para nove meses depois ela vir ganhar o bebê, dai ela sai tranqüila. O pré-natal é importantíssimo. Com certeza, com certeza. É o alicerce, a mãe descobriu-se que está grávida, então ta ela vai fazer o pré-natal, isso eu vejo no PS, no nosso dia-a-dia, uma paciente que não fez pré-natal nossa é tão complicado, a gente tem que redobrar o trabalho, ela está sem orientação nenhuma. ela não sabe nem o que é Aleitamento Materno, a importância da livre demanda, ela não sabe o que é isso, ela não sabe a importância, sabe assim porque falaram, mas não tem dados completos. Esse pré-natal que o Estado dá é um pré-natal muito bom, tem cursinhos para adolescentes. Então, é nossa super humano, a mãezinha ela vai ter o neném preparada, preparada, preparada mesmo e o pré-natal é importante e muito, nossa como influência e é importante para todo mundo, tanto para mãezinha, principalmente para mãe pelo bebezinho e para a equipe que está tratando esta mãe, vai ser mais fácil, porque ela fez o pré-natal. $O$ próprio pré-natal é uma troca de informaçð̃es que para ela é importante. Todo tipo de atendimento, eu acho que influencia na humanização. Sujeitos: (P1, P2, E7, E1, E2, E8, AE1, E6, E3, AE2, F1, AE3)

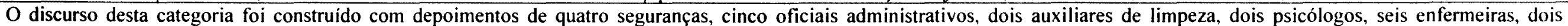
auxiliares de enfermagem e um farmacêutico. 


\section{DISCURSO DO SUJEITO COLETIVO}

\section{Você acha que a história de vida do profissional influencia o processo de humanização da assistência?}

\begin{tabular}{|c|c|c|}
\hline $\begin{array}{c}\text { IDEIA } \\
C E N T R A L C\end{array}$ & \begin{tabular}{|c|} 
Médicos (Obstetras, Residentes, \\
Neonatologistas, Anestesiologistas, \\
UTI Materno e Neonatal)
\end{tabular} & Direção do HMI e Ambulatório \\
\hline $\begin{array}{l}\text { A história de } \\
\text { vida dos } \\
\text { profissionais } \\
\text { influência o } \\
\text { processo de } \\
\text { Humanização } \\
\text { da Assistência, } \\
\text { porque é difícil } \\
\text { separar vida } \\
\text { pessoal do } \\
\text { trabalho }\end{array}$ & $\begin{array}{l}\text { Com certeza, muito. Falando tudo que eu já } \\
\text { voltei anteriormente com certeza. } \\
\text { Influência. Eu acho que toda vida externa } \\
\text { da gente influencia aonde a gente trabalha. } \\
\text { Então, eu acho no dia em que você não está } \\
\text { bem, que aconteceu algum problema em } \\
\text { casa, você está com algum problema até a } \\
\text { nível profissional, mas fora daqui, naquele } \\
\text { dia o seu trabalho eu acho que fica } \\
\text { influenciado, por mais que você fale que } \\
\text { não, mas eu acho que acaba influenciando. } \\
\text { Sujeitos: }(\mathrm{O}, \mathrm{OS})\end{array}$ & $\begin{array}{l}\text { Com certeza, tudo que você, a sua vivência, certo? Você está sempre, tudo que você passa na sua parte médica, na sua } \\
\text { parte de atendimento ou mesmo na parte de enfermagem, essas experiências na medida em que vai entrando no } \\
\text { processo de humanização você vai encaixando situaçðes que você passou dentro do processo que na época você não } \\
\text { dava muito valor e, hoje você consegue trazer e consegue passar. Inclusive, experiência pessoal que você passou, é até } \\
\text { importante quando o médico deixa de ser médico e passa a ser paciente e passa a ser marido de uma paciente, quando } \\
\text { a sua esposa está dando a luz, aí você sente, você sente o outro lado e ai sim é importante essa experiência nesta hora } \\
\text { que você sente a importância do processo de humanização. Nós somos o que construímos como historia de vida. } \\
\text { Alguém com experiência de dar e receber afeto certamente estará mais preparada para a experiência de empatia que } \\
\text { traduz o processo de humanização do que aquele que nunca recebeu afeto. Este nem saberá do que você está falando.. } \\
\text { Nossa história de vida, nossas experiências e nossas emoçðes estão sempre presentes em todas as nossas ações. A } \\
\text { forma como trabalhamos, reagimos diante de dificuldades, aceitamos mudanças, fazemos escolhas, enfrentamos as } \\
\text { dificuldades, estão diretamente ligados ao que somos, o que vivemos e o que sonhamos. Quando buscamos melhorar } \\
\text { as relaçð̃es usuário/profissional, profissional/profissional, chefias/profissionais, estamos trabalhando com relaçðes } \\
\text { entre pessoas. Desta forma, toda história de vida dos atores envolvidos nas açð̃es de saúde influenciam, modificam e } \\
\text { interferem no trabalho desenvolvido. No meu ponto de vista as pessoas estão preocupadas consigo mesmo, só elas tem } \\
\text { problemas, ninguém tem problemas e costuma trazer os problemas para dentro da instituição e isso acaba afetando } \\
\text { tanto no problema inter-relacionamentos entre colegas e entre pacientes, porque querendo ou não tem pessoas que não } \\
\text { sabem distinguir os problemas delas e chega aqui e acabam descontando em todo mundo. Influência. Eu acho que não } \\
\text { tem muito o que falar, é só você conviver diariamente com os profissionais. Até convido a senhora a ficar uma semana } \\
\text { aqui a paisana aqui no hospital que você vai ver o que eu estou falando. } \\
\text { Sujeitos: (DG, DU, DA, DE) }\end{array}$ \\
\hline
\end{tabular}




\section{DISCURSO DO SUJEITO COLETIVO}

\section{Você acha que a história de vida do profissional influencia o processo de humanização da assistência?}

\begin{tabular}{|c|c|c|c|}
\hline $\begin{array}{c}\text { IDEIA } \\
\text { CENTRALC }\end{array}$ & $\begin{array}{l}\text { Profissionais da Área } \\
\text { Administrativa }\end{array}$ & Outros Profissionais da Área Assistencial & $\begin{array}{c}\text { Lideres Setoriais } \\
\text { de Acolhimento }\end{array}$ \\
\hline $\begin{array}{l}\text { A história de } \\
\text { vida dos } \\
\text { profissionais } \\
\text { influência no } \\
\text { processo de } \\
\text { Humanização } \\
\text { da Assistência, } \\
\text { porque é difícil } \\
\text { separar vida } \\
\text { pessoal do } \\
\text { trabalho }\end{array}$ & $\begin{array}{l}\text { Influência, sempre influência. } \\
\text { Não adianta dizer que não. } \\
\text { Realmente tem que ter um jogo } \\
\text { de cintura, para estar entrando } \\
\text { na porta e deixando a sua vida } \\
\text { particular lá fora. Influencia } \\
\text { sim, as vezes por mais que a } \\
\text { gente tente, para separar o } \\
\text { pessoal do profissional é um } \\
\text { pouco dificil, mas a gente } \\
\text { tentando bastante eu acredito } \\
\text { que é possivel, mas, alguns } \\
\text { problemas influenciam muito } \\
\text { na vida profissional das } \\
\text { pessoas, e isso faz com que } \\
\text { mesmo que você não queira } \\
\text { acabe deixando a desejar no seu } \\
\text { trabalho. Ah, influência! Isso } \\
\text { vária de médicos, vária muito, } \\
\text { porque tem médicos que fazem } \\
\text { a sua profissão por amor, tem } \\
\text { outros que já fazem até mesmo } \\
\text { por interesse financeiro. Então } \\
\text { tudo isso influência. } \\
\text { Sujeitos: (S2, OA2, S4) }\end{array}$ & 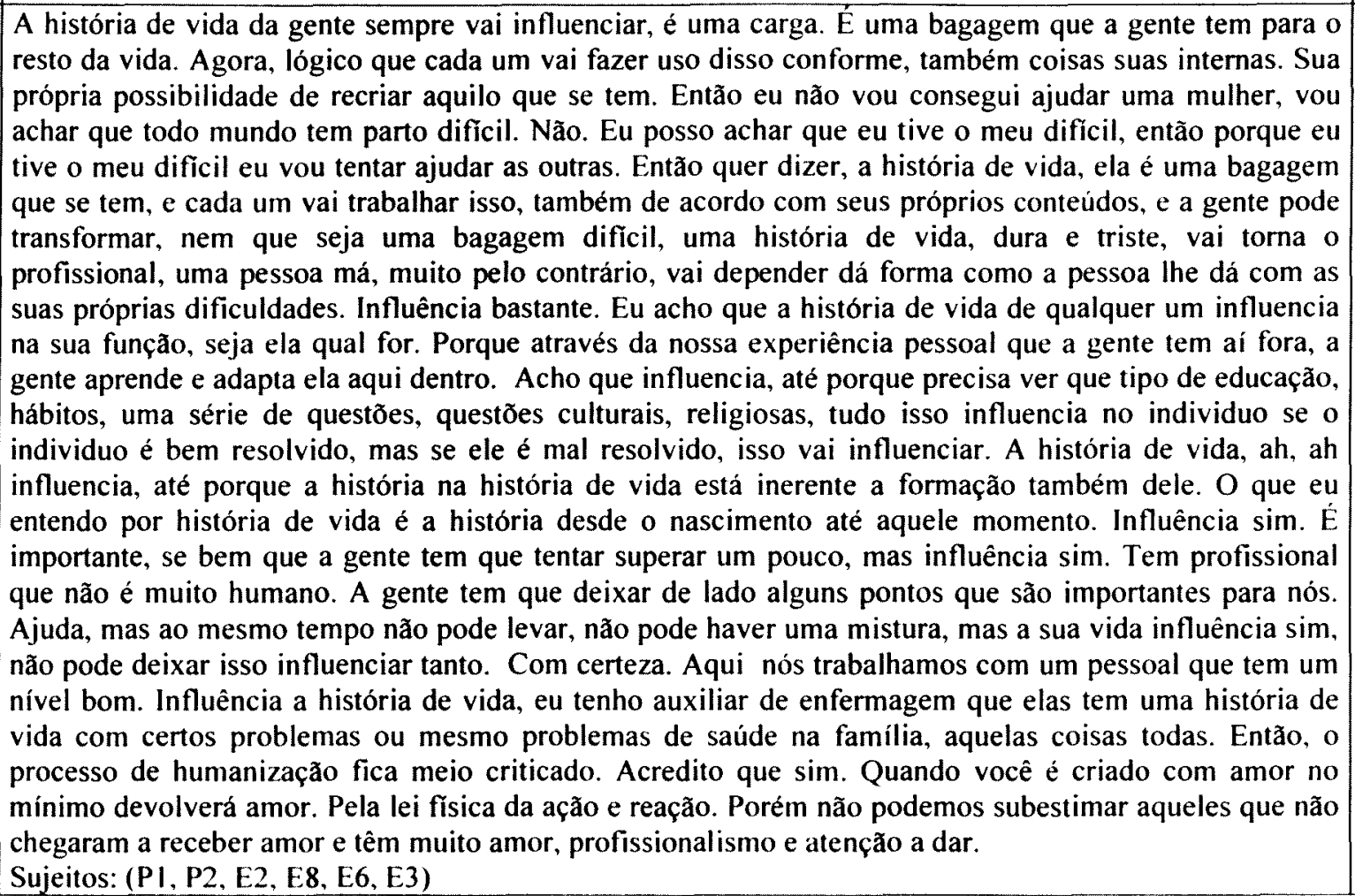 & \\
\hline
\end{tabular}




\section{DISCURSO DO SUJEITO COLETIVO}

Você acha que a história de vida do profissional influencia o processo de humanização da assistência?

\begin{tabular}{|c|c|c|}
\hline $\begin{array}{l}\text { IDEIA } \\
C E N T R A L D\end{array}$ & $\begin{array}{c}\text { Médicos (Obstetras, Residentes, Neonatologistas, Anestesiologistas, UTI Materno e } \\
\text { Neonatal) }\end{array}$ & Direção do HMI e Ambulatório \\
\hline $\begin{array}{l}\text { A historia de } \\
\text { vida dos } \\
\text { profissionais } \\
\text { não atrapalha } \\
\text { o processo de } \\
\text { Humanização } \\
\text { da Assistência, } \\
\text { mas sim a } \\
\text { insuficiência } \\
\text { de Recursos } \\
\text { Humanos para } \\
\text { a alta } \\
\text { demanda }\end{array}$ & $\begin{array}{l}\text { Atrapalha, tipo assim, por exemplo, o volume alto de paciente para poucos profissionais, acaba não dando } \\
\text { para gente dar a atenção devida para cada paciente. Então as vezes atrapalha, por exemplo, se as vezes você } \\
\text { tem num posto de saúde, até o ginecologista. O ginecologista gostaria de orientar bastante as mães, e não } \\
\text { consegue orientar porque? Porque eles têm um volume gigantesco de paciente para atender. Ou aqui as } \\
\text { vezes, aqui o volume é alto de nascimento, a gente gostaria de ter um pouquinho mais de tempo, para poder } \\
\text { orientar mais, apesar que a gente tenta fazer aí bastante, mas assim, um pouquinho mais de tempo para } \\
\text { gente orientar, dá um pouquinho mais de atenção, não só a equipe médica, a equipe de enfermagem que não } \\
\text { tem. As vezes são poucas enfermeiras, poucas auxiliares de enfermagem, e elas tem que dar conta de oito } \\
\text { bebês cada uma, Então não dá para ficar tão em cima, dando tanta atenção, apesar que nós temos aqui as } \\
\text { meninas do banco de leite que nos dão uma força muito grande para colocar o neném no peito, para } \\
\text { estimular, elas vêem aqui e corrigem todas, apega, orientam as mães, então, o que nos ajuda muito aqui } \\
\text { dentro, são as meninas do banco de leite. Porque a gente orienta, e coloca o neném no peito e ensina como } \\
\text { é que apega, mas são quarenta e pouco bebês, então eu tento colocar o máximo que eu posso. As meninas } \\
\text { auxiliares também colocam o máximo que elas podem, mas o que falta para complementar, aquelas mães } \\
\text { com mais dificuldade, nós temos aqui o banco de leite, coisa que eu não encontro em outros hospitais que } \\
\text { eu trabalho, então às vezes sai um pouquinho de falha com outros hospitais, por causa disto. (NI) } \\
\text { Sujeitos: (NI) }\end{array}$ & \\
\hline
\end{tabular}




\section{DISCURSO DO SUJEITO COLETIVO}

\section{Você acha que a história de vida da paciente influencia o processo de humanização da assistência?}

\begin{tabular}{|c|c|c|}
\hline $\begin{array}{c}I D E I A \\
C E N T R A L A\end{array}$ & $\begin{array}{c}\text { Médicos (Obstetras, Residentes, Neonatologistas, } \\
\text { Anestesiologistas, UTI Materno e Neonatal) }\end{array}$ & Direção do HMI e Ambulatório \\
\hline $\begin{array}{c}\text { Não só a } \\
\text { história de } \\
\text { vida das } \\
\text { pacientes, } \\
\text { mas também } \\
\text { da sua } \\
\text { familia, } \\
\text { influenciam o } \\
\text { processo de } \\
\text { Humanização } \\
\text { da } \\
\text { Assistência }\end{array}$ & $\begin{array}{l}\text { A paciente vem já com uma estrutura formada, não só a paciente, os próprios } \\
\text { familiares, quantas vezes eu já cheguei aqui como profissional e a paciente está em } \\
\text { início de trabalho de parto, o pai entra no quarto e fala: "Não. Tem que fazer } \\
\text { cesárea de qualquer jeito." Não é assim. Tem que mudar a idéia não só da paciente, } \\
\text { mas dos familiares e da sociedade. É uma modificação que tem que ter na } \\
\text { sociedade. Elas são muito mal tratadas, muito sofridas! As pacientes da periferia } \\
\text { por exemplo tem muitos filhos. De repente ela já teve vários partos normais, mas } \\
\text { ela conseguiu uma laqueadura. Ai ela quer fazer cesárea porque ela sabe que se ela } \\
\text { fizer cesárea, a laqueadura vai ser feita no mesmo tempo e se ela tiver parto } \\
\text { normal, depois. E também ela tem outros filhos em casa, não tem com quem } \\
\text { deixar. Então ela já quer resolver logo o seu problema. Eu acho que cai naquele } \\
\text { termo da edıcação. De toda a história dela, da vida dela, da compreensão dela, a } \\
\text { gente não sabe até onde vai. Cai no fundo mesmo no processo educativo, não } \\
\text { pejorativo, na educação simples mesmo, na base. Principalmente as condições } \\
\text { socioeconômicas e culturais, se ela já amamentou outros filhos, se ela está } \\
\text { interessada em amamentar. A primeira coisa ela tem que ser orientada sobre os } \\
\text { beneficios da amamentação, a partir daí ela decide, se ela quer ou não amamentar. } \\
\text { Muitas delas já tem histórias de insucesso na amamentação, que já botaram na } \\
\text { cabeça que não querem amamentar porque a mama vai cair, ou porque é mais fácil } \\
\text { dá leite de vaca, esse é o problema. A história da paciente é muito importante. } \\
\text { Uma mulher que tem uma história de vida sofrida, condições sócio-econômicas } \\
\text { muito baixa, ela já vai ter um apego diferente a esse bebê. } \\
\text { Sujeitos: (Ol, O3, O5, NI, N2) }\end{array}$ & $\begin{array}{l}\text { Nem todas entendem que você está querendo ajudá-la. A paciente quando ela } \\
\text { chega no hospital, dependendo do estado emocional dela, ela pode achar que ela } \\
\text { foi muito bem tratada, como ela pode achar que ela não foi muito bem tratada. } \\
\text { Então, tudo vai depender do estado emocional, tanto da paciente quanto do } \\
\text { profissional que está atendendo. Ela chega aqui, não só a paciente o familiar já } \\
\text { vem agredindo, achando que sabe tudo, às vezes não dá para a paciente ficar } \\
\text { porque não tem vaga e a pessoa já vem com um conceito formado, "é publico } \\
\text { então vai ficar por isso, aquilo ou outro". Se a formação dela também for } \\
\text { aceitável como a do profissional, acho que tudo combina. Só que nem sempre é } \\
\text { assim, nem todo mundo aceita as coisas. Eu acho que influência bastante, tanto } \\
\text { da paciente como do seu familiar. Se ela é uma paciente que ela tem um } \\
\text { problema muito sério em casa, vamos supor uma adolescente que tem uma } \\
\text { gravidez que não foi planejada, que não foi desejada, se é uma familia que } \\
\text { acolheu essa gravidez, que tenha essa mãe como: "aí vai nascer um bebezinho" e } \\
\text { tudo, é uma gestação tranqüila, chega aqui tem o neném tranqüila. Agora, se é } \\
\text { uma que o pai põe para fora de casa, sofre violência da familia, desprezo, } \\
\text { preconceito, ela vai chegar aqui ela também vai se sentir meio coagida, vai se } \\
\text { colocar na defensiva. Então, ao meu ponto de vista, por isso que o emocional } \\
\text { influência bastante. Da mesma maneira que aquele que não sabe dar afeto tem } \\
\text { maiores dificuldades de entender a necessidade do outro, aquele que nunca } \\
\text { recebeu afeto não saberá reconhercer - de uma maneira geral - o tratamento mais } \\
\text { humano proposto pela Humanização no Atendimento. } \\
\text { Sujeitos: (DU, DA, DE) }\end{array}$ \\
\hline
\end{tabular}

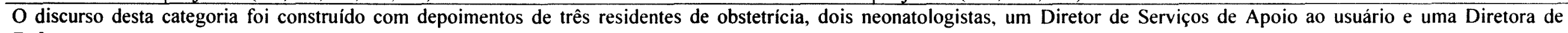
Enfermagem. 


\section{DISCURSO DO SUJEITO COLETIVO}

\section{Você acha que a história de vida da paciente influencia o processo de humanização da assistência?}

\begin{tabular}{|c|c|c|c|}
\hline $\begin{array}{c}\text { IDEIA } \\
\text { CENTRAL.A }\end{array}$ & Profissionais da Área Administrativa & Outros Profissionais da Área Assistencial & $\begin{array}{l}\text { Lideres } \\
\text { Setoriais de } \\
\text { Acolhimento }\end{array}$ \\
\hline $\begin{array}{c}\text { Nãu só a } \\
\text { história de } \\
\text { vida das } \\
\text { pacientes, mas } \\
\text { também da sua } \\
\text { família, } \\
\text { influenciam o } \\
\text { processo de } \\
\text { Humanização } \\
\text { da Assistência }\end{array}$ & $\begin{array}{l}\text { Com certeza, com certeza. Porque se uma mãe } \\
\text { vai ter alta, ela já, pelo próprio bem do filho dela, } \\
\text { realmente acontece que ela lembra, dos filhos que } \\
\text { estão em casa, sendo cuidado pelos vizinhos. } \\
\text { Então, é o caso de estar entendendo ela, às vezes } \\
\text { só o modo de você compreender ela, já a satisfaz, } \\
\text { a gente acolhe de uma maneira, sem saber como } \\
\text { está acolhendo, de estar entendendo o ser } \\
\text { humano é muito de está querendo que você } \\
\text { entenda o problema dele e sofra junto com ele. Se } \\
\text { você falar que entende e ela está ali ciente de que } \\
\text { você é sofredora como o que ela está passando, } \\
\text { isso já faz com que fique acolhida, e está tudo } \\
\text { bem. Com certeza, tem algumas que não querem } \\
\text { ainda ser mãe. Como dizem, a gravidez foi por } \\
\text { um acidente ou já não tem uma boa estrutura na } \\
\text { familia, quando acontece uma coisa assim acaba } \\
\text { mexendo mais ainda. Com a pessoa e } \\
\text { principalmente se o bebê estiver vindo numa hora } \\
\text { assim que não é, digamos assim, uma hora } \\
\text { inoportuna, então acaba influenciando bastante } \\
\text { sim. Sujeitos: (S2, OA2) }\end{array}$ & $\begin{array}{l}\text { Então, são pessoas sofridas lá fora, ela já tem uma vida sofrida, vários filhos, não tem um } \\
\text { parceiro certo, as jovenzinhas que estão se prejudicando. Então tem toda uma problemática, } \\
\text { não é aquela mãe que tem empregada, que o marido vem buscar, o perfil das nossas mãezinhas } \\
\text { é um perfil de periferia mesmo, a maioria, claro que tem um pessoal um pouquinho mais } \\
\text { esclarecido, mas é exatamente isso, a gente tem que estar levando o trabalho de maior } \\
\text { qualidade para estas pessoas. Elas precisam ser bem orientadas. Aí eu já acho que influência. } \\
\text { E o que eu estou te dizendo, porque a gente é claro que não é porque uma tem familia, tem } \\
\text { marido, tem uma condição melhor, o marido trabalha, ela vai ter o mesmo atendimento, não } \\
\text { vai ser assim uma coisa diferenciada, mas com certeza se chegar uma paciente aqui que está } \\
\text { nitidamente claro que é a pessoa está precisada, está debilitada, tem paciente aqui que não tem } \\
\text { nem chinelo para sair, ah eu vou procurar, eu vou dar um apoio, não tem passe para ir embora } \\
\text { as vezes. Então a gente procura, só que é uma coisa que já foge do nosso alcance, a gente } \\
\text { passa para o Serviço Social, agora lá eu não sei. eu nunca ouvi dizer que eles não dão a } \\
\text { informação. A gente espera que o pessoal está fazendo um bom trabalho, mas a história de } \\
\text { vida influência sim. A gente fica meio que querendo fazer o melhor por aquela paciente, é uma } \\
\text { coisa assim, quase que automática, PS, depois sobe para o pré-parto, CO, do CO para o pós- } \\
\text { parto, é uma paciente assim que realmente é uma pessoa que tem algum problema eu acho que } \\
\text { ela acaba sendo beneficiada mais do que as outras dependendo da história. Se a paciente tem } \\
\text { um história de vida complicada, que realmente precisa ser melhor assistida, ela acaba tendo } \\
\text { mais cuidado, mas isso aí não é porque ela é melhor que as outras ou pior que as outras, é o } \\
\text { trabalho da gente estar prestando uma qualidade de serviço a quem realmente está precisando. } \\
\text { Sujeitos: (AE3, AE2) }\end{array}$ & \\
\hline
\end{tabular}




\section{DISCURSO DO SUJEITO COLETIVO}

\section{Você acha que a história de vida da paciente influencia o processo de humanização da assistência?}

\begin{tabular}{|c|c|c|}
\hline $\begin{array}{c}\text { IDELA } \\
\text { CENTRALB }\end{array}$ & $\begin{array}{c}\text { Médicos (Obstetras, Residentes, Neonatologistas, Anestesiologistas, UTI Materno } \\
\text { e Neonatal) }\end{array}$ & Direção do HMI e Ambulatório \\
\hline $\begin{array}{l}\text { Aquelas com maus } \\
\text { antecedentes } \\
\text { obstétricos e lou de } \\
\text { amamentaçào, } \\
\text { dificultam o } \\
\text { processo de } \\
\text { Humanização da } \\
\text { Assistência }\end{array}$ & $\begin{array}{l}\text { As vezes elas não aceitam muito a amamentação. Aqui elas já são psicologicamente preparadas para } \\
\text { aceitar, mas algumas ainda ficam arredias, "ah não, eu vou amamentar por um mês. Eu vou amamentar } \\
\text { por no mínimo } 6 \text { meses". "Ah doutora eu vou dar só um, dois meses e vou voltar a trabalhar." Não. } \\
\text { Você vai ter que tirar o leite e guardar na geladeira não vai? Alguém não fica com o bebê? Alguém não } \\
\text { vai ter que preparar o leite para o bebê, enquanto você está no trabalho? Então porque não preparar o } \\
\text { leite materno ao eives de preparar o leite da vaca? Mas elas acham mais fácil comprar o leite de } \\
\text { caixinha do que ordenhar o leite materno que é de graça e melhor para o neném. Ela tem uma vida mais } \\
\text { sofrida, ela tem um parto, um bebê com sequelas. Já não vai estar tranquila no trabalho de parto } \\
\text { normal. Sujeitos: }(\mathrm{N} 1, \mathrm{~N} 2)\end{array}$ & $\begin{array}{l}\text { Depende da população que você atende. Depende } \\
\text { também da bagagem que esta paciente trás para } \\
\text { você poder dar ou não este tipo de cuidado. Se ela } \\
\text { não estiver preparada ou ela nem sabe o que está } \\
\text { acontecendo, ela talvez não valorize aquilo que está } \\
\text { sendo feito para ela. Eu acho que também cabe a } \\
\text { instituição não só fornecer, mas também informar a } \\
\text { essa paciente o que está acontecendo aqui. } \\
\text { Sujeitos: (DC) }\end{array}$ \\
\hline
\end{tabular}
normal. Sujeitos: (N1, N2)

O discurso desta categoria foi construído com depoimentos dois neonatologistas e um Diretor Clínico.

\begin{tabular}{|c|c|c|c|}
\hline $\begin{array}{c}\text { IDEIA } \\
\text { CENTR ALC }\end{array}$ & Profissionais da Área Administrativa & Outros Profissionais da Área Assistencial & $\begin{array}{l}\text { Líderes Setoriais } \\
\text { de Acolhimento }\end{array}$ \\
\hline $\begin{array}{l}\text { Aquelas com maus } \\
\text { antecedentes } \\
\text { obstétricos e /ou de } \\
\text { amamentação, } \\
\text { dificultam o processo } \\
\text { de Humanização da } \\
\text { Assistência }\end{array}$ & $\begin{array}{l}\text { Da paciente, se ela já teve um parto, já teve um trauma } \\
\text { qualquer de outro, de outro parto no caso, problema com o } \\
\text { marido, com a familia, as vezes não tem um médico no } \\
\text { hospital. Vem sempre com aquele medo, insegurança, sem } \\
\text { saber o que vai encontrar pela frente. Mas aí é a família. Vai de } \\
\text { pessoas para pessoa. As vezes a falta de informação também, } \\
\text { tem algumas que nem pré-natal fez. Fica dificil de responder. } \\
\text { lnfluência. Porque ela, a pessoa passa por certas fases, assim, } \\
\text { que eu acho que acaba, acarretando isso, e ela fica com a } \\
\text { lembrança. Então tem muitas vezes que, é quase que um } \\
\text { bloqueio }\end{array}$ & $\begin{array}{l}\text { Se ela já teve um parto, já teve um trauma qualquer de outro, de } \\
\text { outro parto no caso, problema com o marido, com a familia, as } \\
\text { vezes não tem um médico no hospital. Vem sempre com aquele } \\
\text { medo, insegurança, sem saber o que vai encontrar pela frente. Mas } \\
\text { ai é a família né? Vai de pessoas para pessoa, né? As vezes a falta } \\
\text { de informação também, tem algumas que nem pré-natal fez. Na } \\
\text { verdade é um caso, né, então fica dificil de responder. Influência. } \\
\text { Porque ela, a pessoa passa por certas fases, assim, que eu acho que } \\
\text { acaba, acarretando isso, e ela fica com a lembrança. Então tem } \\
\text { muitas vezes que, é quase que um bloqueio. } \\
\text { Sujeitos: (AEI, FI) }\end{array}$ & \\
\hline
\end{tabular}




\section{DISCURSO DO SUJEITO COLETIVO}

Você acha que a história de vida da paciente influencia o processo de humanização da assistência?

\begin{tabular}{|c|c|c|}
\hline $\begin{array}{l}I D E I A \\
C E N T R I L D\end{array}$ & $\begin{array}{c}\text { Médicos (Obstetras, Residentes, Neonatologistas, Anestesiologistas, UTI Materno e } \\
\text { Neonatal) }\end{array}$ & $\begin{array}{l}\text { Direção do HMI e } \\
\text { Ambulatório }\end{array}$ \\
\hline $\begin{array}{l}\text { As parturiente muitu jovens } \\
\text { ou aquelas com idade mais } \\
\text { avançada são as que mais } \\
\text { dão trabalho no ciclo } \\
\text { gravidico-puerperal }\end{array}$ & $\begin{array}{l}\text { Contribui muito, com certeca contribui muito. As pacientes principalmente nos extremos da vida, ou as } \\
\text { adolescentes, geralmente são as pacientes que mais dão trabalho para o trabalho de parto e no pré-natal, } \\
\text { eu não sei porque. Cheguei a fazer pré-natal na residência, mas no momento que eles estão ali no pré- } \\
\text { parto, em trabalho de parto, são as que mais dão trabalho. Então, influencia sim, mas eu acho que tudo } \\
\text { isso começa no pré-natal. Sujeitos: (RB) }\end{array}$ & \\
\hline
\end{tabular}

\section{DISCURSO DO SUJEITO COLETIVO}

Você acha que a história de vida da paciente influencia o processo de humanização da assistência?

\begin{tabular}{|c|c|c|}
\hline $\begin{array}{c}I D E I A \\
C E N T R A L E\end{array}$ & Médicos (Obstetras, Residentes, Neonatologistas, Anestesiologistas, UTI Materno e Neonatal) & $\begin{array}{c}\text { Direção do HMI } \\
\text { e Ambulatório }\end{array}$ \\
\hline $\begin{array}{l}\text { Existe na } \\
\text { sociedade a } \\
\text { cultura da } \\
\text { cesárea }\end{array}$ & $\begin{array}{l}\text { A paciente também vem já com uma estrutura formada, onde antigamente você tinha as pessoas que faziam os partos em casa, as parteiras. } \\
\text { Algumas pacientes, onde você já tem a visita do médico em casa, que já tem essa idéia de cesárea, elas não querem o parto normal. Os } \\
\text { próprios familiares, a paciente está em início de trabalho de parto, o pai entra no quarto e fala: "Não. Tem que fazer cesárea de qualquer } \\
\text { jeito". Tem que mudar a idéia não só da paciente, mas também da sociedade. É uma modificação que tem que ter na sociedade. A cultura } \\
\text { da cesárea está muito sedimentada entre as mulheres. Sim. Elas são muito mal tratadas, muito sofridas! Sujeitos: (OI, O3) }\end{array}$ & \\
\hline
\end{tabular}




\section{IDISC IRSO DO SIJEITO COI EIIVO}

\section{Você acha que a história de vida da paciente influencia o processo de humanização da assistência?}

\begin{tabular}{|c|c|c|c|}
\hline $\begin{array}{c}\text { IDELA } \\
\text { CENTR ILF }\end{array}$ & Profissionais da Área Administrativa & Outros Profissionais da Área Assistencial & $\begin{array}{l}\text { Lideres Setoriais } \\
\text { de Acolhimento }\end{array}$ \\
\hline $\begin{array}{l}\text { Não só a história de } \\
\text { vida das pacientes, } \\
\text { mas também as } \\
\text { questões sócio- } \\
\text { econômica-culturais } \\
\text { influenciam o } \\
\text { processo de } \\
\text { humanização da } \\
\text { assistência }\end{array}$ & $\begin{array}{l}\text { Tanbém, tambem. Porque eu acho assim, tem que ver se é, } \\
\text { por exemplo, à gestação foi planejada, ou seja, se ela } \\
\text { realmente ela está feliz com esta, com a gestação, ou seja } \\
\text { com a situação que ela está vivendo em si. Então influência } \\
\text { muito, quer dizer se é uma gravidez desejada, tudo eu creio } \\
\text { que vai correr bem. Se tudo for bem com a mãe, agora se é } \\
\text { uma gravidez que a mãe não desejou, ou seja, aconteceu tal, } \\
\text { acho que influência. Influencia sim, porque eu já peguei } \\
\text { muita paciente aqui que é cabeça dura, que tem medo até de } \\
\text { um dentista quanto mais de um médico obstètrico. Onde } \\
\text { pessoas, maridos de pacientes que não deixava a mulher ter } \\
\text { um exame de toque por puro preconceito. Tem muito marido } \\
\text { de paciente que é muito ignorante, não sabe que o exame de } \\
\text { toque faz parte de todo o procedimento que ela tem que ter e } \\
\text { acha que vai fazer sacanagem com a mulher dele. Eu acho } \\
\text { que até o que influencia muito são os parentes da paciente, } \\
\text { do que a própria paciente. Tem acompanhantes de paciente } \\
\text { que brigam muito com a gente, achando que a gente está } \\
\text { fazendo tudo errado, que a gente está fazendo um processo } \\
\text { lento, mas é de acordo com as possibilidades que o hospital } \\
\text { nos fornece. Eu jả peguei acompanhante assim. } \\
\text { Sujeitos: (S4, OA4) }\end{array}$ & $\begin{array}{l}\text { Eu acho que sim. Porque tem muitas pacientes, que a gente, as vezes } \\
\text { elas se abrem com a gente, você vai conversar, você vê, mulher de } \\
\text { bandido, mulher que foi estuprada, mulher que foi estuprada pelo } \\
\text { marido, atrapalha um pouco. Não que atrapalhe ela sempre, ela traz com } \\
\text { ela. Então as vezes, a gente, tem paciente que está mal, você vai } \\
\text { conversar, aí ela começa a contar um pouco da vida dela, que é dureza, } \\
\text { as vezes passa fome. Não tem nem onde morar direito. As vezes é um } \\
\text { filho que os pais não aceitam a criança, filho que é rejeitado pelo } \\
\text { marido, pelo namorado. A história de vida da mulher também } \\
\text { influencia, porque se ela foi criada com hábitos culturais, então } \\
\text { colocamos assim, uma indigena que vem para uma maternidade, não } \\
\text { vai dar certo, não vai dar certo, porque? Porque ela tem hábitos culturais } \\
\text { diferenciados. Inclusive tem algumas religiões, algumas culturas que } \\
\text { quando a mulher vai dar a luz, a família inteirinha tem que ficar do lado. } \\
\text { Isso eu assisti muito porque meu pai tinha uma clientela diferente e era } \\
\text { assim a cultura, todos estavam na hora do parto, a familia inteirinha, se } \\
\text { tinha } 50 \text { componentes, tava todo mundo na maternidade esperando o } \\
\text { nascimento daquela criança. E ali no quarto que a gente tinha que pedir } \\
\text { para as pessoas sairem, para mulher não ficar estressada, mas a cultura é } \\
\text { que obrigava a mulher a fazer aquilo. } \\
\text { Sujeitos: (E7, E2) }\end{array}$ & \\
\hline
\end{tabular}




\section{DISC IIRSO DO SUJEITO COI IIIIO}

\section{Você acha que a história de vida da paciente influencia o processo de humanização da assistência?}

\section{IDEIA \\ CENTR IL F}

Não só a história de vida das pacientes, mas também as questôes sócioeconômica-culturais influenciam o processo de humanização da assistência

\section{Profissionais da Área Administrativa}

Também, também. Porque eu acho assim, teın que ver se é, por exemplo, à gestação foi planejada, ou seja, se ela realmente ela está feliz com esta, com a gestação, ou seja com a situação que ela está vivendo em si. Então influência muito, quer dizer se è uma gravidez desejada, tudo eu creio que vai correr bem. Se tudo for bem com a mãe, agora se é uma gravidez que a mãe não desejou, ou seja, aconteceu tal, acho que influência. Influencia sim, porque eu já pegue muita paciente aqui que é cabeça dura, que tem medo até de um dentista quanto mais de um médico obstétrico. Onde pessoas, maridos de pacientes que não deixava a mulher ter um exame de toque por puro preconceito. Tem muito marido de paciente que é muito ignorante, não sabe que o exame de toque faz parte de todo o procedimento que ela tem que ter acha que vai fazer sacanagem com a mulher dele. Eu acho que até o que influencia muito são os parentes da paciente do que a própria paciente. Tem acompanhantes de pacient que brigam muito com a gente, achando que a gente está fazendo tudo errado, que a gente está fazendo um processo lento, mas é de acordo com as possibilidades que o hospita nos fornece. Eu já peguei acompanhante assim Sujeitos: (S4, OA4)

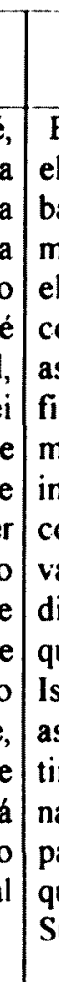

Lideres Setoriais
de Acolhimento
a

O discurso desta categoria foi construido com depoimentos de um segurança, um oficial administrativo e duas enfermeiras 